\title{
of Temperature Measurement
}

\section{January 1953 to December 1969}

U.S. PARTMENT

OF OMMERCE National Bureau Standards of 
The National Bureau of Standards ${ }^{1}$ was established by an act of Congress March 3 , 1901. The Bureau's overall goal is to strengthen and advance the Nation's science and technology and facilitate their effective application for public benefit. To this end, the Bureau conducts research and provides: (1) a basis for the Nation's physical measurement system, (2) scientific and technological services for industry and government, (3) a technical basis for equity in trade, and (4) technical services to promote public safety. The Bureau consists of the Institute for Basic Standards, the Institute for Materials Research, the Institute for Applied Technology, the Center for Computer Sciences and Technology, and the Office for Information Programs.

THE INSTITUTE FOR BASIC STANDARDS provides the central basis within the United States of a complete and consistent system of physical measurement; coordinates that system with measurement systems of other nations; and furnishes essential services leading to accurate and uniform physical measurements throughout the Nation's scientific community, industry, and commerce. The Institute consists of a Center for Radiation Research, an Office of Measurement Services and the following divisions:

Applied Mathematics-Electricity-Heat-Mechanics-Optical Physics-Linac Radiation ${ }^{2}$ - Nuclear Radiation ${ }^{2}$ - Applied Radiation ${ }^{2}$ - Quantum Electronics ${ }^{3}$ Electromagnetics ${ }^{3}$ - Time and Frequency ${ }^{3}$ - Laboratory Astrophysics ${ }^{3}-$ Cryogenics ${ }^{3}$.

THE INSTITUTE FOR MATERIALS RESEARCH conducts materials research leading to improved methods of measurement, standards, and data on the properties of well-characterized materials needed by industry, commerce, educational institutions, and Government; provides advisory and research services to other Government agencies; and develops, produces, and distributes standard reference materials. The Institute consists of the Office of Standard Reference Materials and the following divisions:

Analytical Chemistry-Polymers-Metallurgy-Inorganic Materials-Reactor Radiation-Physical Chemistry.

THE INSTITUTE FOR APPLIED TECHNOLOGY provides technical services to promote the use of available technology and to facilitate technological innovation in industry and Government; cooperates with public and private organizations leading to the development of technological standards (including mandatory safety standards), codes and methods of test; and provides technical advice and services to Government agencies upon request. The Institute also monitors NBS engineering standards activities and provides liaison between NBS and national and international engineering standards bodies. The Institute consists of a Center for Building Technology and the following divisions and offices:

Engineering Standards Services-Weights and Measures-Invention and Innovation-Product Evaluation Technology-Electronic Technology-Technical Analysis-Measurement Engineering-Fire Technology-Housing Technology ${ }^{4}$ -Federal Building Technology 4 -Building Standards and Codes Services ${ }^{4}$ Building Environment ${ }^{4}$-Structures, Materials and Life Safety ${ }^{4}$-Technical Evaluation and Application.

THE CENTER FOR COMPUTER SCIENCES AND TECHNOLOGY conducts research and provides technical services designed to aid Government agencies in improving cost effectiveness in the conduct of their programs through the selection, acquisition, and effective utilization of automatic data processing equipment; and serves as the principal focus within the executive branch for the development of Federal standards for automatic data processing equipment, techniques, and computer languages. The Center consists of the following offices and divisions:

Information Processing Standards-Computer Information-Computer Services -Systems Development-Information Processing Technology.

THE OFFICE FOR INFORMATION PROGRAMS promotes optimum dissemination and accessibility of scientific information generated within NBS and other agencies of the Federal Government; promotes the development of the National Standard Reference Data System and a system of information analysis centers dealing with the broader aspects of the National Measurement System; provides appropriate services to ensure that the NBS staff has optimum accessibility to the scientific information of the world, and directs the public information activities of the Bureau. The Office consists of the following organizational units:

Office of Standard Reference Data-Office of Technical Information and Publications-Library-Office of International Relations.

\footnotetext{
${ }^{ \pm}$Headquarters and Laboratories at Gaithersburg, Maryland, unless otherwise noted; mailing address Washington, D.C. 20234

2 Part of the Center for Radiation Research.

3 Located at Boulder, Colorado 80302 .

4 Part of the Center for Building Technology.
} 


\section{NOV 81974 \\ not acc-Ref.}

QC100

Paul D. Freeze and Leslie P. Parker

Institute for Applied Technology

National Bureau of Standards

Washington, D.C. 20234

t.special publication no. 373

This publication supersedes NBS Monograph 27 issued April 6, 1961, and Supplements 1 and 2 to Monograph 27, issued September 13, 1963, and April 28, 1967, respectively.

U.S. DEPARTMENT OF COMMERCE, Peter G. Peterson, Secrefary

NATIONAL BUREAU OF STANDARDS, Lawrence M. Kushner, Acting Director, 
Library of Congress Catalog Card Number: 72-600291

National Bureau of Standards Special Publication 373

Nat. Bur. Stand. (U.S.), Spec. Publ. 373,140 pages (Nov. 1972)

CODEN: XNBSAV

For sale by the Superintendent of Documents, U.S. Government Printing Office, Washington, D.C. 20402 (Order by SD Catalog No. C13.10:373). Price $\$ 2.00$ 
Introduction . . . . . . . . . . . . . . . . . . . . . . . . . . . . . . . . . 1

1. Thermoelectric theory and calibration . . . . . . . . . . . . . . . . . . .

2. Thermoelectric devices... . . . . . . . . . . . . . . . . . . . . . . 3

3. Resistance devices . . . . . . . . . . . . . . . . . . . . . . . . . 6

4. Radiation devices . . . . . . . . . . . . . . . . . . . . . . . . . . . . . . 7

5. Expansion devices . . . . . . . . . . . . . . . . . . . . . . . . . . 9

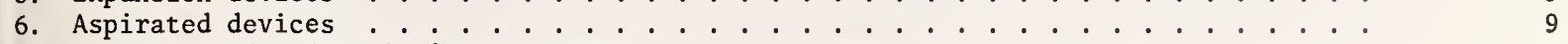

7. Other methods, descriptive articles . . . . . . . . . . . . . . . . . . . . . . . 10

8. Special applications, method not specified in title . . . . . . . . . . . . . . . .

9. Nuclear application of temperature measurement . . . . . . . . . . . . . . . . . . 12

10. Associated equipment and testing procedure . . . . . . . . . . . . . . . . . 12

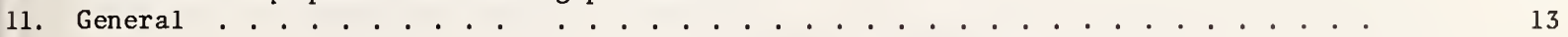

\section{JULY 1960 TO DECEMBER 1962}

Introduction . . . . . . . . . . . . . . . . . . . . . . . . . . . . . . . . . . . . . . 1

1. Thermoelectric theory and calibration . . . . . . . . . . . . . . . . . 1

2. Thermoelectric devices. . . . . . . . . . . . . . . . . . . . . . . . . . . . . . . 3

3. Resistance devices . . . . . . . . . . . . . . . . . . . . . . . . . . . 6

4. Radiation devices . . . . . . . . . . . . . . . . . . . . . . . . . . . . . . . 7

5. Expansion devices . . . . . . . . . . . . . . . . . . . . . . . . . 10

6. Aspirated devices . . . . . . . . . . . . . . . . . . . . . . . . . 10

7. Other methods, descriptive articles . . . . . . . . . . . . . . . . . . . . .

8. Special applications, method not specified in title . . . . . . . . . . . . . . . . 1

9. Nuclear applications of temperature measurement . . . . . . . . . . . . . . . . . . 12

10. Associated equipment and testing procedure . . . . . . . . . . . . . . . . . . . . 12

11. General . . . . . . . . . . . . . . . . . . . . . .

JANUARY 1963 TO DECEMBER 1965

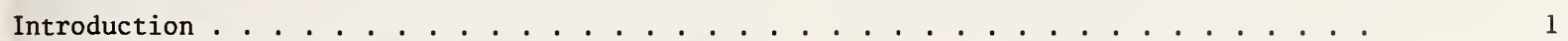

1. Theory, calibration and temperature scales... . . . . . . . . . . . . . . . . . 2

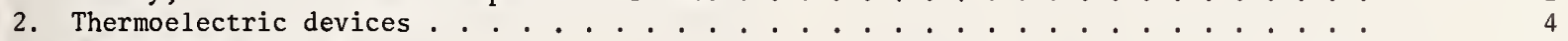

3. Resistance devices... . . . . . . . . . . . . . . . . . . . . . . . . . . . . . . . . . . . . . . . . . . . . . . . . . . . .

4. Radiation devices . . . . . . . . . . . . . . . . . . . . . . . . 13

5. Expansion devices . . . . . . . . . . . . . . . . . . . . . . . . . 18

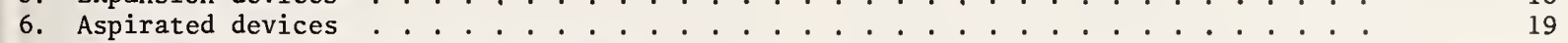

7. Other methods, descriptive articles . . . . . . . . . . . . . . . . . . . . . . . . 19

8. Special applications, method not specified in title . . . . . . . . . . . . . . . . . 22

9. Nuclear applications of temperature measurement . . . . . . . . . . . . . . . . . 25

10. Associated equipment and testing procedure . . . . . . . . . . . . . . . . . . . 27

11. General . . . . . . . . . . . . . . . . . . . . . . . . . 29

\section{JANUARY 1966 TO DECEMBER 1969}

Introduction . . . . . . . . . . . . . . . . . . . . . . . . . . . . . . . . . . . 1

1. Theory, calibration and temperature scales... . . . . . . . . . . . . . . . . . . 3

2. Thermoelectric devices... . . . . . . . . . . . . . . . . . . . . 6

3. Resistance devices . . . . . . . . . . . . . . . . . . . . . . . . . . . . . . . . . . . . . . . . . . . . . . . .

4. Radiation devices . . . . . . . . . . . . . . . . . . . . . . . . . . . . . . 25

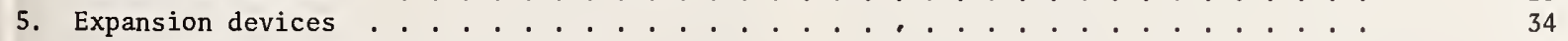

6. Aspirated devices . . . . . . . . . . . . . . . . . . . . . . . . . . . . . . . . . . . . . . . . . . . . . . . . .

7. Other methods, descriptive articles . . . . . . . . . . . . . . . . . . . . . 35

8. Special application, method not specified in title................. . . . . 41

9. Nuclear applications of temperature measurement . . . . . . . . . . . . . . . . . . 4 48

10. Associated equipment and testing procedure . . . . . . . . . . . . . . . . . . . . . 52

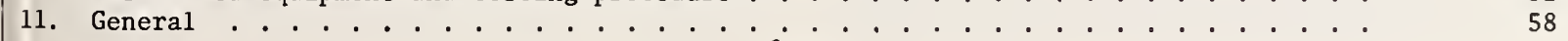




\section{Abstract}

This bibliography consolidates into a single publication National Bureau of Standards Monograph 27 (January 1953 to June 1960) and its two supplements (September 13, 1963 and April 28, 1967, respectively) together with 1800 new references covering essentially the period from January 1966 to December 1969, but including some earlier citations previously omitted. The consolidated publication, which supersedes the earlier bibliographies, thus covers literature of temperature measurement published between January 1953 and December 1969.

In general, the arrangement of material in this new edition is the same as in Monograph 27, and the journal abbreviations are those employed in Chemical Abstracts. However, starting with 1963, and in the new material, scope of coverage in Part 1 was broadened to include theory, calibration, and temperature scales in addition to the previous categories of thermoelectric theory and calibration.

Key words: Fluidic thermometers; pyrometry; radiation pyrometry; temperature measurement; thermistors; thermocouple; the rmometry . 


\title{
Bibliography of Temperature Measurement
}

\author{
January 1953 to June 1960
}

\author{
Carl Halpern and Robert J. Moffat*
}

\begin{abstract}
There are presented more than 500 references to the field of temperature measurement. These references were collected from two general sources: Scientific and technical literature and government reports. The period covered is from 1953 to June 1960, with some from earlier dates. For convenience of the user, the references are divided into a number of categories based on the type of instrument used. Some references to calibration of instruments and to scientific theories, on which temperature measurement is based, are also presented.
\end{abstract}

\section{Introduction}

The original version of this bibliography was compiled in 1957 by Robert J. Moffat of the Research Laboratories, General Motors Corporation, for the AE-2 Committee, Physical Measurement Sensing, of the Society of Automotive Engineers. Later, a Bibliography Subcommittee was formed to keep abreast of the current literature, and supplements have been compiled by Carl Halpern of the National Bureau of Standards. George E. Glawe of the Lewis Research Center, National Aeronautics and Space Administration; and John W. Fulton, Wright Air Development Division, U.S. Air Force, have also assisted in furnishing references. Because of the favorable response to and the continued demand for copies of the bibliography and its supplements, it was decided to issue it in a more permanent form for wider circulation.

The material contained herein was collected from two general sources: Scientific and technical journals, and reports of investigations sponsored or conducted by various governmental agencies. These latter are mostly distinguished as ASTIA or PB reports. ASTIA reports may be obtained from the Armed Services Technical Information

"Research Laboratories, General Motors Corporation, Warren, Mich.
Agency, Arlington Hall Station, Arlington 12, Va. $\mathrm{PB}$ reports designated as OTS may be obtained from Office of Technical Services, U.S. Department of Commerce, Washington 25, D.C.; those designated as LC may be obtained from the Library of Congress, Washington 25, D.C. Some agencies such as the National Advisory Committee for Aeronautics and its successor the National Aeronautical and Space Administration, Washington 25, D.C., issue their own reports.

The topical subdivisions are shown in the table of contents. Each subdivision is arranged chronologically and within the chronological sections, alphabetically by author. "Anonymous" articles appear at the end of each section. The period covered is from January 1953 to June 1960 with some earlier entries.

The journal abbreviations used are those employed in Chemical Abstracts. Volume numbers are in bold-faced type and the date of issue is given where page numbers do not run consecutively throughout a given volume. Since the year of issue appears at the head of each chronological section, this is not repeated in the individual references unless publication was in more than one year. References made to unpublished papers presented before various societies are designated by the abbreviation M.P. 


\section{Thermoelectric Theory and Calibration}

\section{8}

Cullitz, B. D., The thermoelectric properties and electrical conductivity of bismuth-selenium alloys, Metals Technol. 15, No. 1 (Jan.).

1952

Eatherly, W. P., and N. S. Rasor, Thermoelectric power of graphite, dependence on temperature type and neutron irradiation, U.S. Atomic Energy Comm. NAA-SR196 (Nov.).

Tyler, W. W., and A. C. Wilson, Thermal conductivity, electrical resistivity, and thermoelectric power of titanium alloy RC-130-B, U.S. Atomic Energy Comm. KAPL 803 (Sept.).

\section{3}

Corruccini, R. J., and H. Shenker, Modified 1917 reference table for iron/constantan thermocouples, J. Research Nat. Bur. Standards 50, 229.

Domenicali, C. A., Irreversible thermodynamics of thermoelectric effects in inhomogeneous, anisotropic media, Phys. Rev. 92, 877 (Nov. 15)

Holtan, H., Jr., P. Mazur, and S. R. De Groot, On the theory of thermocouples and thermocells, Physica 19, 1109.

MacDonald, D. K. C., and S. K. Roy, Thermoelectric power of univalent metals at high temperature, Phil. Mag. 44, 1364.

McSherry, P. B., Method for modifying the thermal emf/ temperature characteristics of a constantan thermocouple, Iron Age 172, 100 (Oct. 29).

Middleton, A. E., and W. W. Scanlon, Measurement of the thermoelectric power of germanium at temperatures above $78^{\circ} \mathrm{R}$, Phys. Rev. 92, 219 (Oct. 15).

Mortlock, A. J., The effect of tension on the thermoelectric properties of metals, Australian J. Phys. 6, No. 4, 410 (Dec.).

Shoens, C. J., and J. W. Shortall, Thermoelectric calibration of zirconium-constantan and zirconium-Alumel thermocouples, U.S. Atomic Energy Comm. LRL 62 (Dec.).

\section{4}

Domenicali, C. A., and F. A. Otter, Thermoelectric power and electron scattering in metal alloys, Phys. Rev. 95, 1134 (Sept. 1).

Fuschillo, N., Inhomogeneity emfs in thermoelectric thermometers, J. Sci. Instr. 31, No. 4, 133 (Apr.).

Herring, C., Theory of the thermoelectric power of semiconductors, Phys. Rev. 96, 1163 (Dec. 1).

Mazur, P., Thermopotentials in thermocells, J. Chem. Phys. 58, 700 (Sept.).

Patrick, L., and A. W. Lawson, Thermoelectric power of pure and doped AgBr, J. Chem. Phys. 22, 1492 (Sept.).

Potter, R. D., Calibration of nickel-molybdenum thermocouples, J. Appl. Phys. 25, No. 11, 1383 (Nov.).

Tauc, J., Theory of thermoelectric power in semi-conductors, Phys. Rev. 95, 1394 (Sept. 15).

\section{5}

Domenicali, C. A., and F. A. Otter, Thermoelectric power and electrical resistivity of dilute alloys of silicon in copper, nickel, and iron, J. Appl. Phys. 26, 377 (Apr.).

Droms, C. R., and A. I. Dahl, Iridium versus iridiumrhodium thermocouples for gas-temperature measurements up to $3500^{\circ} \mathrm{F}$, Proc. Joint Conf. Combustion (1955), p. 330.

Frederikse, H. P. R., and E. V. Mielczarerek, Thermoelectric power of indium antimonide, Phys. Rev. 99, 1889 (Sept. 15).
Mooser, E., and S. B. Woods, Thermoelectric power of germanium at low temperature, Phys. Rev. 97, 1721 (Mar. 15).

Parravano, G., Thermoelectric behavior of nickel oxide, J. Chem. Phys. 23, 5 (Jan.).

Pearse, D. J., Electrical parasites hamper temperature measurement, Steel Processing 41, No. 1, 22 (Jan.).

Rasor, N. S., Low temperature thermal and electrical conductivity and thermoelectric power of graphite, U.S. Atomic Energy Comm. NAA-SR-1061 (Jan.).

\section{6}

Benel, H., Study of the thermoelectromotive force of unimetallic (thin Ag/thick Ag) and bimetallic (thin $\mathrm{Ag} /$ thick $\mathrm{Cu}$ or thick $\mathrm{Ag} /$ thin copper) couples as a function of the thickness of the thick branches, Rev. fac. sci. univ. Istanbul 21C, 216 .

Bodine, J. H., Јr., Hall coefficient and thermoelectric power of thorium metal, Phys. Rev. 102, 1459 (June 15).

Cooper, H., ct al., Thermoelectric power of $\mathrm{AuCu}$ in nonequilibrium states, J. Appl. Phys. 27, 516 (May).

Goland, A. N., and A. W. Ewald, Thermoelectric power of gray tin, Phys. Rev. 104, 948 (Nov. 15).

Kammer, E. W., Changes in thermoelectric power of copper with cold work at liquid nitrogen temperatures, Phys. Rev. 104, 265 (Oct. 1).

Lepontre, G., and J. F. Dewald, Thermoelectric properties of metal-ammonia solutions, J. Am. Chem. Soc. 78, 2953 (July 5).

Loebner, E. E., Thermoelectric power, electrical resistance and crystalline structure of carbons, Phys. Rev. 102, 46 (Apr, 1).

Otter, F. A., Jr., Thermoelectric power and electrical resistivity of dilute alloys of $\mathrm{Mn}, \mathrm{Pd}, \mathrm{Pt}$ in $\mathrm{Cu}, \mathrm{Ag}, \mathrm{Au}$, J. Appl. Phys. 27, 197 (Mar.).

Price, P.J., Theory of transport effects in semi-conductors: thermoelectricity, Phys. Rev. 104, 1223 (Dec. 1).

Price, P. J., Theory of transport effects in semi-conductors; the Nernst coefficient and its relation to thermoelectric power, Phys. Rev. 102, 1245 (June 1).

Rudnitskii, A. A., and I. I. Tyurin, Study and selection of alloys for high-temperature thermocouples, Zhur. Neorg. Khim. 1, 1074.

Taylor, J. C., and B. R.Coles; Thermoelectric powers in palladium-silver and palladium-rhodium alloys, Phys. Rev. 102, No. 1, 27 (Apr. 1).

1957

Allen, L., Thermocouple reference voltage supply, Directorate of flight and all-weather testing, Wright-Patterson Air Force Base, Ohio, U.S. Air Force Wright Air Development Center, Tech. Note 57-364 (Oct.), PB 133211 .

Bunch, M. D., and R. L. Powell, Calibration of thermocouples at low temperatures, Proc. Cryogenic Eng. Conf., Boulder 195\%, p. 269.

Domenicali, C. A., Thermoelectric power and resistivity of solid and liquid germanium in the vicinity of its melting point, J. Appl. Phys. 28, 749.

Fisher, R. V., A typical problem in engineering-find the resistance values of a thermocouple-potentiometer circuit, Gen. Motors Eng. J. 5, 58 (Apr.).

Ioffee, A., Thermoelectric and thermal properties of semiconductors, J. phys. radium 18, 209 (Apr.).

Johnson, N. R., A. S. Weinstein, and F. Osterle, Influence of gradient temperature field on thermocouple measurement, PB 132585 (LC).

Kanclir, E., Calibration of thermocouple for differential thermal analysis, Chem. zvesti 11, 566.

Parravano, G., and C. A. Domenicali, Thermoelectric behavior of solid particulate systems; nickel oxide, J. Chem. Phys. 26, 359 (Feb.).

Ubbelohde, A. R., and J. Orr, Anisotropic thermoelectric effects in graphite, Nature 179, 193. 
Hatsopoulas, G. N., and J. H. Keenan, Thermoelectric effects and irreversible thermodynamics, J. Appl. Mech. $25,428$.

Jan, J. P., W. P. Pearson, and I. M. Templeton, Thermoelectricity at low temperature, Can. J. Phys. :6, 627.

Joffe, A. F., The revival of thermoelectricity, Sci. American 199,31 (Nov.).

Kammerer, E. W., Changes in thermoelectric power of silver and gold with cold work at liquid-nitrogen temperature, J. Appl. Phys. 29, 1122.

Lachman, J. C., Calibration of rhenium-molybdenum and rhenium-tungsten thermocouples to $4000^{\circ} \mathrm{F}$, U.S. Atomic Energy Comm. APEX-365.

Levin, G. M., and V. I. Vol'mir, Characteristic thermal inertia curves of conventional thermocouples and resistance thermometers, Measurement Techniques No. 6, 686.

Mortlock, A. J., Error in temperature measurement due to the interdiffusion at the hot junction of a thermocouple, J. Sci. Instr. 35, 283 (Aug.).

Tsuji, M., Thermoelectric, galvanomagnetic, and thermomagnetic effects of univalent metals, J. Phys. Soc. Japan $13,133$.

\section{9}

Benedict, R. P., The calibration of thermocouples by freezing-point baths and empirical equations, Trans. Am. Soc. Mech. Engrs. (J. Eng. for Power) 81A, 177.

Boerdijk, A. H., Contribution to a general theory of thermocouples, J. Appl. Phys. 30, 1080 (July).

Donaldson, I. G., Temperature errors introduced by temperature measuring probes, Brit. J. Appl. Phys. 10, 225 (June).

Lachman, J. C., Calibration of thermocouples to $4000^{\circ} \mathrm{F}$, Instruments and Control Systems 32, 1032 (July).

Timo, D. P., Thermocouple errors during temperature transients, Ind. Labs. 10, 6 (June) ; 110 (Oct.).

\section{0}

Almond, R. J., Errors in thermocouple circuits, Instruments and Control Systems 33, 80 (Jan.).

Caldwell, F. R., L. O. Olsen, and P. D. Freeze, Intercomparison of thermocouple response data, S.A.E. M.P. $158 \mathrm{~F}$.

Scadron, M. D., Time response characteristics of temperature sensors, S.A.E. M.P. 158H.

Stauss, H. E., Thermoelectricity, PB 145603 (LC).

Wormser, A. F., Experimental determination of thermocouple time constants with use of variable turbulence, variable density wind tunnel, and analytic evaluation of conductance, radiation, and other secondary effects, S.A.E. M.P. $158 \mathrm{D}$.

\section{Thermoelectric Devices}

\section{8}

Wilhelm, H. A., et al., High temperature thermocouples, U.S. Atomic Energy Comm. AECD 3275 (June; reprint 1955).

\section{1}

Boelter, L. M. K., and R. W. Lockhart, An investigation of aircraft heaters XXXV-thermocouple conduction error observed in measuring surface temperatures, Natl. Advisory Comm. Aeronaut. Tech. Note 2427.

\section{2}

Miller, Edward S., and Paul L. Munter, Temperature probe recovery factor for $B-1$ free air temperature bulb on B-47 aircraft, ASTIA AD-7225 (Dec.).

Steven, G., and W. C. Troy, Development of temperaturesensing elements for jet engines, PB 122122 (LC); ASTIA AD-3562 (Apr.).
Andrews, C. R., Capacitance welding technique for the installation of thermocouples, U.S. Air Force Wright Air Development Center Tech. Rept. 53-289, PB 134778 (LC).

Barnum, J. R., O. E. Buxton, J. M. Nau, and W. Robinson, Device for measurement of rotor hot-spot temperatures of aircraft generators by means of thermocouples, PB 128526 (LC); ASTIA AD-29 975 (Nov.).

Benedict, R. P., Thermocouples-their use and limitations, ASTIA AD-5672 (Jan.).

Clement, J. R., et al., Carbon-composition thermometers at very low temperatures, Rev. Sci. Instr. 24, 545 (July).

Dallow, Thomas P., and John M. Davis, Flight tests to determine the temperature recovery factor and thermal response of several free air temperature probes, ASTIA AD-8246 (Mar.).

Fiock, Ernest F., and Andrew I. Dahl, Temperature measurements in high-velocity stream of hot gas, Proc. Iowa Thermodynamics Symposium (Apr.), State Univ. Iowa, Iowa City, Iowa, p. 190; ASTIA AD-70 705.

Fiock, Ernest F., and Andrew I. Dahl, The measurement of gas temperature by immersion-type instruments, $\mathrm{J}$. Am. Rocket Soc. 23, 155.

Potter, R. D., Open circuit thermocouples, Metal Progr. 64, No. 5, 80 (Nov.).

Shepard, C. E., and I. Warshawsky, Electrical techniques for time lag compensation of thermocouples used in jet engines, Instruments 26, 1725 (Nov.).

Simons, J. P., C. G. Hamstead, and E. J. Burton, Tungsten/molybdenum thermocouple for immersion pyrometry, J. Iron Steel Inst. (London) 175, Part 4, 402 (Dec.).

Slater, C. H. W., Improvements in fine wire thermocouples, J. Sci. Instr. 30, 293 (Aug.).

Sucher, Max, Leonard Sweet, and Herbert J. Carlin, The operation of bolometers under pulsed power conditions, ASTIA AD-16 893 (May).

Torgerson, Frederick A., Investigation of a thermocouple rake for measuring ramjet fuel/air distribution (Model Bomarc), ASTIA AD-66 221 (Oct.).

Werner, Frank D., Robert K. Keppel, and M. A. Bernards, Design and performance studies for improved multiple-shielded total temperature probes, ASTIA AD27727 (Apr.).

West, W. E., Jr., and J. W. Westwater, Radiation-conduction correction for temperature measurements in hot gases, Ind. Eng. Chem. 45, No. 10, 2152 (Oct.).

\section{4}

Benedict, R. P., Thermistors vs thermocouples for temperature measurements, Elec. Mfg. 54, No. 2 (Aug.).

Chamberlain, H. H., Jet engine thermocouple averaging systems, Aero Dig. 69, No.6, 47 (Dec.).

Clayton, William H., Temperature measurements at Caplen Pier, ASTIA AD-47 740 (Aug.).

Ehringer, H., The life of $\mathrm{Pt} / \mathrm{Rh}$ thermocouples, Metall 8, 596 (Aug.).

Fiock, Ernest F., and Paul D. Freeze, Evaluation of exhaust-gas thermocouples and harness from a MIG-15 airplane, U.S. Air Force Wright Air Development Center Tech. Rept. 54-552 (July); ASTIA AD-59 641.

Glawe, G. E., and C. E. Shepard, Some effects of exposure to exhaust gas streams on emittance and thermoelectric power of bare-wire platinum rhodium-platinum thermocouples, Natl. Advisory Comm. Aeronaut. Tech. Note 3253.

Humphreys, J. D., Probe recovery factor, Instr. and Automation 27, No. 2 (Feb.).

Krag, J., Improved needle thermocouple for subcutaneous and intramuscular temperature measurements in animals and man, Rev. Sci. Instr. 25, No. 8, 799 (Aug.).

Kruithof, A. M., Some remarks on measurement of furnace temperatures by thermocouples, Philip's Gloeilampenfubrieken, Separaat 2209 (paper before Third Int. Congress on Glass). 
Murphy, E. A., Theory and application of thermocouples, Heating Ventilating Mag. 51, No. 2, 104 (Feb.).

Pearson, W. B., Thermocouples for use at low temperatures, J. Sci. Instr. 31, No. 12, 444 (Dec.).

Rauch, W. E., Design and construction of needle thermocouples, Metal Progr. 65, No. 3, 71 (Mar.).

Simmons, F. S., Recovery corrections for butt welded straight-wire thermocouples in high velocity, high temperature gas streams, Natl. Advisory Comm. Aeronaut. Research Mem. E54G22a.

Sims, L. G. A., Measurement of temperature by thermocouple and galvanometer, Engineering 17\%, 180 (Feb. 5).

Sturm, W. J., and R. J. Jones, Applications 'of |thermocouples to target temperature measurement in the internal beam of a cyclotron, Rev. Sci. Instr. 25, 292 (Apr.).

Upton, D. E., Design for embedded thermocouple, Engineering 17\%, No. 4603, 489 (Apr. 16).

Winkler, Eva M., Design and calibration of stagnation temperature probes for use at high supersonic speeds and elevated temperatures, J. Appl. Phys. 25, 231 (Feb.).

Unique thermocouple, Mech. Eng. 76, 518 (June).

\section{5}

Barber, C. R., and L. H. Pemberton, Silver-palladium thermocouples, J. Sci. Instr. 32, 486 (Dec.).

Benseman, R. F., and H. R. Hart, Thermocouple anemometer, J. Sci. Instr. 32, 145 (Apr.).

Bollenger, L. E., Thermocouple measurements in R.F. field, J. Instr. Soc. Am. 2, No. 9, 338 (Sept.).

Clark, J. A., Response of temperature measuring elements to thermal transients, Am. Soc. Mech. Engrs. M.P. 55SA18.

Dike, P. H., Thermoelectric thermometry 2d ed., Leeds and Northrup Co., Philadelphia, $\mathrm{Pa}$.

Gordon, C. K., Jr., Comparison between air temperatures as measured by various shielded test thermocouples and a reference double-shielded aspirated thermocouple, ASTIA AD-80 593 (Aug.).

Huber, W. R., and L. G. Ekholm, Benefits derived from use of bath thermocouple, Proc. Am. Inst. Mining Eng. 38, 57 (Apr.).

Jewell, R. C., E. G. Knowles, and T. Land, High temperature thermocouple, Metal Ind. (London) 87, No. 11, 217, 221 (Sept. 9).

Kaufman, A. B., and P. R. Mitchell, How accurate are your reference temperature baths, Instr. and Automation 28, No. 3, 450 (Mar.).

Kiernan, E. F., Preparation of copper-constantan thermocouples, J. Sci. Instr. 32, 321 (Aug.).

Koletsky, Harold, A temperature indication system for exhaust gas, turbine-inlet and other engine temperatures, ASTIA AD-75 051 (July).

Ladt, M. A., Let's install thermocouple to measure tube temperature, Power 99, No. 12, 118 (Dec.)

Lowell, Herman H., and Norman Patton, Response of homogeneous and two-material laminated cylinders to sinusoidal environmental temperature change, with applications to hot-wire anemometry and thermocouple pyrometry, Natl. Advisory Comm. Aeronaut. Tech. Note 3514 (Sept.); ASTIA AD-71 186.

Schenker, H., et al., Reference tables for thermocouples, Nat. Bur. Standards (U.S.) Circ. 561 (Apr.).

Spooner, N. F., and J. M. Thomas, Longer life for ChromelAlumel thermocouples, Metal Progr. 68, No. 5, 81 (Nov.).

Srikantiah, G., and A. Ramachandran, Temperature messurements in low velocity high temperature gas streams, J. Indian Inst. Sci., Sec. B 37, No. 1, 41 (Jan.).

Stickney, T. M., Recovery and time response characteristics of 6 thermocouple probes in subsonic and supersonic flow, Natl. Advisory Comm. Aeronaut. Tech. Note 3455.

Wisely, H. R., Thermocouples for measurement of high temperatures, Ceram. Age 66, No. 1, 15 (July).

Attaching thermocouples by capacitance welding, Naval Gun Factory Tech. Rept. NGF-T-21-55; PB 121901 (OTS).
Wire, electrical, Chromel and/or Alumel thermocouple, Notice 1, MIL-W-5846A, U.S. Department of Defense (Dec. 1).

Wire, electrical, copper and constantan thermocouple, Notice 1, MIL-W-5908B, U.S. Department of Defense (Dec. 14).

Wire, electrical, iron and constantan, thermocouple, Notice 1, MIL-W-5845A, U.S. Department of Defense (Dec. 1).

\section{6}

Atkinson, P. G., Measurement of gas stream temperatures in industrial appliances, Gas Council (London), Research Comm. GC 33 (Nov.).

Benel, H., Thermoelectric couples made of several chemically different layers, Rev. fac. sci. univ. Istanbul $\mathbf{2 1 C}$, 272.

Betzenhowser, R. J., Thermocouples-these industrial watchdogs need testing and protecting, Plant Eng. 10, No. 3, 116 (Mar.).

Corey, R. C., Measurement of gas temperature with thermocouples, Combustion 28, No. 4, 47 (Oct.).

Engardt, N. N., Platinorhodium-platinum thermocouples made from purer materials, Izmer, Tekh. No. 2,20 .

Freeze, P. D., and F. R. Caldwell, Performance tests of jet engine thermocouples, U.S. Air Force Wright Air Development Center Tech. Rept. 56-476 (Aug.),

Glawe, G. E., F. S. Simmons, and T. M. Stickney, Radiation and recovery corrections and time constants of several Chromel-Alumel thermocouple probes in high temperature, high velocity gas streams, Natl. Advisory Comm. Aeronaut. Tech. Note 3766.

Guettel, C. L., New thermocouple for service in reducing atmospheres, Bull. Am. Soc. Testing Materials 64 (Sept.); Metal Progr. 69, 89 (Apr.).

Haase, G., and G. Schneider, Investigation of thermocouples of the system iridium/rhenium, Z. Physik 144, 256.

Hall, J. L., Temperature measurements in kilns, Calif. J. Min. 52, 207.

Lacroix, R., Use of platinum metals in thermometry, Rev. met. $53,48$.

Palmer, J. F., Jr., and R. S. Barnes, Modified thermocouple for peak exotherm measurement, Anal. Chem. 28, 427 (Mar.).

Perrot, M., and G. Peri, On certain thermocouples, J. phys. radium 17, 355 (June).

Reishaus, M., Temperature measurements in ceramic kilns, Sprechsaal 89, 158 (Sept.).

Samal, E., The accuracy of temperature measurements with thermocouples in practice, Elektrotech. Z. 8B, 199 (May).

Sawada, F. H., P. D. Freeze, C. J. Carter, and E. F. Fiock, Development and evaluation of ceramic coatings for thermocouples, U.S. Air Force Wright Air Development Center Tech. Rept. 56-135 (Mar.); ASTIA AD-97 495.

Shepard, R. L., H. S. Patten, and R. D. Westbrook, High-temperature boron-graphite thermocouple, Bull. Am. Phys. Soc. 1, 119.

Stepka, F. S., and R. O. Hickel, Methods of measuring temperatures of thin walled gas turbine blades, Natl. Advisory Comm. Aeronaut. Research Mem. E56G17.

Wedell, T., Flue gas temperature measurements, Tek. Tidskr. 86, 777.

Weise, E. K., and A. C. Hershberger, Simple thermocouple needle thermometer with high sensitivity, PB 119554 (LC) (Apr.).

Molten-metal pyrometer, Engineering 18R, 182 (Aug. 10).

Preparation and use of Chromel Alumel thermocouples for turbojet engines, Soc. Automotive Engrs. AIR \#46.

Simple changes eliminate temperature errors, Elec. World 146, 99 (Aug. 6).

Thermocouples, contact, aircraft engine spark plug gasket-type, MIL-T-5494A, U.S. Department of Defense (Nov. 28). 
Seiner, J. A., Level measurement in frothing liquids with multiple thermocouple, Chem. Eng. 65, 178 (May 19).

Alexander, G. L., Development of subsonic and supersonic total temperature probes for a blow-down type wind tunnel, Texas U.D.R.L. Rept. 399 (AFOSR TN 57(164), ASTIA AD-126 456 (June).

Bitler, W. R., Ling Yang, and G. Derge, Measurement of the thermoelectric power of a molten FeS-solid tungsten thermocouple, J. Appl. Phys. 28, 514.

Chaston, J. C., Thermocouple for high temperatures. Advantages of the "Five-Twenty" couple, Platinum Metals Rev. 1, 20 (Jan.).

Fuschillo, N., Low temperature scale from 4 to $300^{\circ} \mathrm{K}$ in terms of a gold-cobalt versus copper thermocouple, J. Phys. Chem. 61, 644.

Glawe, G. E., and R. C. Johnson, Experimental study of heat transfer to small cylinders in a subsonic, hightemperature gas stream, Natl. Advisory Comm. Aeronaut. Tech. Note 3934 .

Hett, J. H., Wedge thermocouples, NYU-TM3, PB 131862 (OTS).

Johnson, N. R., A. S. Weinstein, and F. Osterle, The influence of gradient temperature fields on thermocouple measurements, Abstract, Mech. Eng. 79, 960; Am. Soc. Mech. Engrs.-Am. Inst. Chem. Engrs. Heat Transfer Conf. Paper No. 57-HT 18.

Kessler, R., The behavior of thermocouples in intermittent radiation under the influence of internally generated heat waves, Z. Angew. Phys. 9, 408.

Kilpatrick, P. W., Accuracy of thermocouples in parallel, Instr. and Automation 30, 1706 (Sept.).

Lodding, W., and E. Sturn, A new method of differential thermal analysis employing multiple thermocouples, Am. Mineralogist 42, 78 (Jan.).

Moffat, R. J., How to specify thermocouple response, ISA Journal (June).

Murphy, A. H., and G. Stevens, Fast-response thermocouple using tubular hot-junction elements, Abstract, Mech. Eng. 79, 879; Am. Soc. Mech. Engrs. SemiAnnual M.P. 57-SA-1.

Paludan, C. T. N., Thermocouple application for ballistic missiles, Missiles and Rockets 2, 185 (Oct.).

Parize and Pignon, Measurement of temperatures by thermocouples in aeroplanes during fight, Tech. Sci. Aeronaut. No. 1, 15.

Reid, R. J., Fast response thermocouple, Electronic Design Mag. (July 1).

Tugarinow, N. I., G. S. Moskvichev, and A. A. Eremin, New design of tungsten-graphite thermocouple, Zavod. Lab. 23, 92.

Vlasov, K. P., and N. V. Kokushkin, Temperature measurement of flowing gases in flames by means of thermocouples, Izvest. Akad. Nauk, S.S.S.R., Otdel-Tekh. Nauk, No. 8, p. 137.

Thermocouples for reducing atmospheres, Petrol. Engr. 29, C34 (Aug.).

\section{8}

Bennett, H. E., Noble metal thermocouples, 2d ed, Johnson, Matthey and Co., London.

Doyle, R. T., Metering gas with a heated thermopile, Instruments 30, 2276.

Fischer, W. A., and G. Lorenz, Development of an oxide thermocouple, Arch. Eisenhüttenw. 29, 293.

Gaylord, E. W., W. F. Hughes, F. C. Appl, and E. F. Ling, On the theoretical analysis of a dynamic thermocouple, Trans. Am. Soc. Mech. Engr. 80, 307.

Haase, R., Thermocouples, Z. physik. Chem. (Frankfurt) 14, 292.

Hunsinger, W., Temperature measurements with thermocouples, Arch. Tech. Messen 266, 57.

Le May, J. L., More accurate thermocouples with percussion welding, ISA Journal 5, 42 (Mar.).

Moffat, R. J., Designing thermocouples for response rate, Trans. Am. Soc. Mech. Engrs. 80, 257.

Monteith, J. L., and P. C. Owen, Thermocouple method for measuring relative humidity in the range 95-100 percent, J. Sci. Instr. 35, 443 (Dec.).
Shpigelman, E. S., Surface thermocouples, Measurement Techniques No. 6, 685 .

Sitnik, G. F., Tungsten-tantalum thermocouple, Vestnik Moskov. Univ., Ser. Mat., Mekh., Astron., Fiz., Khim. 13, No. 1, 86.

Solet, I. S., Elimination of cold-junction error in therrmocouple measurements in electron tubes, Rev. Sci. Instr. 29, 73 (Jan.)

Thomas, A. R., B. Schuren, and J. C. Morris, Temperature error associated with imbedded thermocouples, Rev. Sci. Instr. 29, 1045 (Nov.).

Thermoelectric circuits and the performance of several current jet engine thermocouples, Soc. Automotive Engrs., AIR \#65 (Aug. 1).

\section{9}

Bennett, H. E., Care of platinum thermocouples, Glass Ind. 40, 190 (Apr.).

Brühl, R., Measurements of temperature in wire drawing with a wire drawing die thermocouple using hard metal ball core, Wire and Wire Prod. 34, 573 (May).

Carlson, J. F., Low-temperature-emf characteristics of Chromel-Alumel thermocouples, Ind. Heating 26, 688.

Colclough, C. D., and J. Smillie, Welding fine thermocouple wires to large metal bodies, Engineer 208, 696 .

Deissinger, W. W., Accuracies of thermocouples on directfired heater tubes, ISA Journal 6, 94 (Sept.).

Dutton, R., and E. C. Lee, Surface-temperature measurement of current carrying thermocouple circuit, ISA Journal 6, 49 (Dec.).

Grover, G., Direct A-power electı icity without using steam turbine; plasma thermocouple, Elec. Eng. 78, 717 (June).

Grover, G. M., Los Alamos plasma thermocouple, Nucleonics 17, 54 (July).

Lever, R. C., Better thermocouple alloys make $1800 \mathrm{C}$ measurement feasible, S.A.E. Journal 67, 48 (Oct.).

Lewis, H. W., and J. R. Reitz, Open-circuit voltages in the plasma thermocouple, J. Appl. Phys. 30, 1833.

Moeller, C. E., Special thermocouple solves surfacetemperature problem, ISA Journal 6, 47 (June).

Moser, H., and P. Rahles, The Pt/Pt-Rh thermocouple in the international temperature scale, Procès-verbaux séances, Comité intern. poids et mesures, Ser. 2, 26A, T78.

O'Conner, H., Thermocouple practice in ferrous foundry temperature control, Foundry 87, 98 (July).

Okada, K., and H. Satone, Annealing of wires of standardized thermocouples, Procès-verbaux séances, Comité intern. poids et mesures, Ser. 2, 26A, T211.

Penney, R. W., Developing a nomogram for differential temperatures in a thermocouple system, ISA Journal 6, 75 (May).

Pidd, R. W., et al., Characteristics of a plasma thermocouple, J. Appl. Phys. 30, 1861.

Pidd, R. W., Plasma thermocouple converts energy directly, Elec. Eng. 78, 878 (Aug.).

Schubert, H. V., Immersion thermocouple practice, Iron Steel Eng. 36, 91 (Jan.)

Shirakawa, Y., T. Ohara, and D. Amemiya, Thermocouples with nonlinear characteristics composed of ironaluminum-chromium and copper-nickel alloys, Sci. Repts. Research Insts., Tohoku Univ., Ser. A11, 190.

Sims, C. T., G. B. Gaines, and R. I. Jaffee, Refractory metal thermocouples containing rhenium, Rev. Sci. Instr. 30, 112 (Feb.).

Stoneburner, D. F., L. Yang, and G. Derge, Measurement of the thermoelectric power of several molten sulfidesolid-tungsten thermocouples, Trans. Am. Inst. Mining, Met. Petrol. Engrs. 215, 879.

Terrell, O. D., Reduce errors in your temperature measurements, Power 103, 190 (Aug.).

Ubbelohde, A. R., L. C. F. Blackman, and P. H. Dundas, A graphite/graphite thermocouple for high temperature, Chem. and Ind. (London) No. 19, 595 (May 9).

Mineral insulated thermocouples, Engineer 207, 927 (June 12); Engineering 187, 717 (May 29). 


\section{0}

Anderson, A. R., and D. J. MacKenzie, Materials for high $(2500-4000 \mathrm{~F})$ gas engine temperature measurements, S.A.E. M.P. 158 B.

Carlson, J. F., Low temperature characteristics of ChromelAlumel thermocouples, Instruments and Control Systems 33, 98 (Jan.).

Clem, J. D., Jr., Development of a special thermocouple for measuring transient temperatures within a solid body, Rev. Sci. Instr. 31, 334 (Mar.).

Davies, D. A., Two thermocouples suitable for measurement of temperatures up to $2800^{\circ} \mathrm{C}, \mathrm{J}$. Sci. Instr. 37, 15 (Jan.).

Haig, L. B., Design procedure for thermocouple probes, S.A.E. M.P. $158 \mathrm{C}$

Hunt, M. H., Design and use of fine wire thermocouples for research, PB 144481 (LC).

Ihnat, M. E., and W. C. Hagel, A thermocouple system for measuring turbine-inlet temperatures, Trans. Am. Soc. Mech. Engrs. (J. Basic Eng.) 82D, 81.

Kane, M. V., Thermocouple current indicators, Instr. and Control Systems 33, 600 (Apr.).

Kaufman, A. B., Using thermocouples with non-standard reference temperatures, Instruments and Control Systems 33, 106 (Jan.).

Kelly, D., Thermocouple temperature measurement without special instruments, Instruments and Control Systems 33, 76 (Jan.).

Lachman, J. C., and F. W. Kuether, Stability of rhenium/ tungsten thermocouples in hydrogen atmospheres, ISA Journal y, 67 (Mar.).

Meador, J. D., Dynamic testing of gas sampling thermocouples, S.A.E. M.P. $158 \mathrm{G}$.

Potts, J. F., Jr., and D. L. McElroy, Basic studies on basemetal thermocouples, S.A.E. M.P. 158 A.

Shaw, V. G., High temperature measurement-thermocouples, total radiation, brightness (optical) pyrometer and two-color pyrometer, Instruments and Control Systems 33, 58 (Jan.).

Steven, G., and W. C. Troy, The mechanical protection of the W/Ir thermocouple, PB 138319, 138452, and 138456 (LC)

Wood, R. D., An experimental investigation of hypersonic stagnation temperature probes. Rept. on hypersonic research project, PB 144167 (LC).

Zysk, E. D., Developments on high temperature thermocouples using noble metals, Englehard Inds. Tech. Bull. 1, 8 (June)

Metallic thermocouples for the measurement of temperatures above $1600^{\circ} \mathrm{C}$, Metallurgia 61, 141 (Mar.).

Still hotter horizons for thermocouples, Engineering 189, 806.

Thermocouples for temperatures up to $2800^{\circ} \mathrm{C}$, Engineering $189,122$.

\section{Resistance Devices}

1950

Dahl, A. I., Kearfott temperature-sensing bulbs, PB 113066 (LC) (July).

\section{3}

Muller, R. H., and H. J. Stolten, Use of thermistors in precise measurements of small temperature differences, Anal. Chem. 25, 1103 (July).

Wright, G. M., Direct reading thermistor thermometer for aircraft use, PB 112649 (LC); ASTIA AD-21 947 (June).

\section{4}

Benedict, R. P., Thermistors vs thermocouples for temperature measurements, Elec. Mfg. 54, No.2 (Aug.).

Dauphinee, T. M., and H. Preston-Thomas, Copper resistance temperature scale, Rev. Sci. Instr. 25, 884 (Sept.).

Hutchinson, W. P., et al., Temperature control of a large water bath using a resistance thermometer, J. Sci. Instr. 31, 420 (Nov.).
LeMar, R. L., Procedure for the use of the platinum resistance thermometer as a temperature standard, U.S. Arsenal, Rock Island, Ill. (June); PB 126455 (LC); ASTIA AD-39 464.

McLean, J. A., Method for constructing direct reading thermistor thermometers, J. Sci. Instr. 31, No. 12, 455 (Dec.).

Piccard, J., H. Larsen, and J. Blomstrand, Thin wire thermometer for radiosondes, Rev. Sci. Instr. 25, 959 (Oct.).

Sias, F. R., et al., Tungsten resistance thermometer, Elec. Eng. 73, 442 (May).

Sims, L. G. A., Measuring fine temperature changes, Engineering 17\%, 15 (Jan. 1).

Tellerman, J., Measuring transistor temperature rise, Electronics 27, 185 (Apr.).

Wisely, H. R., P. D. Freeze, and E. F. Fiock, Study of thermistor materials for use as temperature-sensing elements in the high-velocity exhaust gases of jet-type engines, U.S. Air Force Wright Air Development Center Tech. Rept. 54388 (Nov.); PB 122463 (LC).

Woods, R. W., Thermistor electronic thermometer, Science 121, 337 (Mar. 4).

\section{5}

Barber, C. R., Platinum resistance thermometer for use at low temperatures, J. Sci. Instr. 32, 416 (Nov.).

Muller, R. H., Resistance thermometer, instrument for determining freezing point, Anal. Chem. 27, S $33 \mathrm{~A}$ (Dec.).

Rounthwaite, C., Double wire method of resistance thermometry in gaseous explosions, Fuel 34, S 59 (Apr.).

White, A. G., Transistor as a thermometer, J. Sci. Instr. 32, 451 (Nov.).

Winding, C. C., L. Topper, and B. V. Baus, Metal film resistance thermometers for measuring surface temperatures, Ind. Eng. Chem. 47, 386 (Mar.).

\section{6}

Beck, A., Stability of thermistors, J. Sci. Instr. 33, 16 (Jan.).

Benson, G. W., The use of thermistors in precision thermometry, Nat. Research Council Can. Rept. MI-817 (Oct. 22).

Blackburn, G. F., P. D. Freeze, and F. R. Caldwell, A study of thermistor materials for use as temperature sensing elements in the high velocity exhaust gases of jet-type engines, U.S. Air Force Wright Air Development Center Tech. Rept. 54-388, Supplement No. 1 (Apr.).

Cole, G. H., Transistorized indicator measures jet exhaust, Electronics 29, 143 (Dec.).

Cole, G. H., Transistors are now measuring heat of exhaust in jet engines, Midwest Engr. 8, 14 (Apr.).

Parkinson, D. H., and L. M. Roberts, A resistance thermometer for use at helium temperatures, Proc. Phys. Soc. (London) B68, 386.

Rabinowicz, J., and others, Resistance thermometer for transient high temperature studies, J. Appl. Phys. 27, 97 (Jan.).

Simpson, T. B., and C. C. Winding, Properties of evaporated metal films related to their use for surface temperature measurement, A.I.Ch.E. Journal \&, No. 1 (Mar.).

Bulbs, electrical resistance type thermometry $-70^{\circ}$ to $+150^{\circ}$ C, Notice 1, MIL-B-5495, U.S. Department of Defense (Oct. 15)

\section{7}

Badgley, F. I., Response of radiosonde thermistors, Rev. Sci. Instr. 28, 1079.

Belfield, W., and R. W. Johnson, Thermistor probe, J. Sci. Instr. 34, 209

Cole, Kenneth S., Thermistor thermometer bridge: Linearity and sensitivity for a range of temperature, Rev. Sci. Instr. 28, No. 5 (May). 
Kunzler, J. E., et al., Germanium resistance thermometers suitable for low-temperature calorimetry, Rev. Sci. Instr. 28, 96 (Feb.).

Markham, A. H., R. G. Nitzel, and J. R. Dillinger, Carbon resistor thermometry below $1^{\circ} \mathrm{K}, \mathrm{Rev}$. Sci. Instr. 28, No. 5, 382 (May).

Mason, G. L., A fast-response resistance thermometer system for simultaneous recording of air temperature at a number of separated points, Bull. Am. Meteorol. Soc. 38, 391.

Sachse, B., Missile research points to low resistance thermistors as ultra-cold thermometers, Electronic Inds. Tele-Tech. 16, 55 (Jan.).

Seiden, P. E., Wide-range thermistor vacuum gage, Rev. Sci. Instr. 28, 657.

Trey, F., Resistance thermometers from semi-conductors, Radex Rundschau, No. 2, 519.

White, G. K., and S. B. Woods, Indium resistance thermometer, 4 to $300^{\circ} \mathrm{K}$, Rev. Sci. Instr. 28, 638 (Aug.).

Wisely, H. R., An exhaust gas temperature thermistor body for the range $1500^{\circ} \mathrm{F}$ to $3500^{\circ} \mathrm{F}, \mathrm{U} . \mathrm{S}$. Air Force Wright Air Development Center Tech. Rept. 57-27 (Jan.); ASTIA AD-110 722

Types and applications of thermistors, Machine Design 29, 178 (Dec. 12).

\section{8}

Anderson, J. C., Temperature measurement with thermistors, Electronic and Radio Eng. 35, 80 (Mar.).

Blake, C., et al., Resistance thermometer bridge for measurement of temperatures in the liquid helium range, Rev. Sci. Instr. 29, 715 (Aug.).

Broom, R. F., Low-temperature resistance thermometer using p-type gallium arsenide, J. Sci. Instr. 35, 467 (Dec.)

Goodwin, R. D., Design of simple resistance thermometer bridges for wide-range control of low temperatures, Rev. Sci. Instr. 29, 497 (June).

Loffler, H. J., and H. Henrici, Measurement of surface temperatures with vapor-deposited resistance thermom. eter, Chem. Ingr. Tech. 30, 708 .

Melville, A. W., High stability mains-operated recording thermistor thermometer, J. Sci. Instr. 35, 179 (May).

Senin, V. S., Experience in measuring the temperature of liquids by means of thermistors, Measurement Techniques No. 6,683 .

Soble, A. B., Thermistors for linear temperature readings, Electronic Ind. 17, 66 (Nov.).

White, G. K., S. B. Woods, and F. Anglin, Indium resistance thermometer, Rev. Sci. Instr. 29, 181.

Zima, G. E., Introduction to a résistance thermometric method and qualitative metallic probe technique for rocket motor combustion analysis, CIT JPL 9-18; PB 130851 (LC).

Germanium resistance thermometer, Bell Labs. Record 36, 261 (July).

Germanium resistance thermometer, Elec. Eng. 77, 660 (July).

Germanium resistance thermometer, Mech. Eng. 80, 92 (June).

Low temperature resistance thermometer, Elec. Mfg. 61, 9 (May).

Temperature measurements at absolute zero, germanium resistance thermometer, Electronics 31, 84 (Apr. 25).

Tiny resistance thermometer made of germanium crystal, Machine Design 30, 14 (May 15).

\section{9}

Jason, A. C., and A. Lees, Resistance thermometer spear for field measurement, J. Sci. Instr. 36, 272 (June).

Marrone, P. V., and R. A. Hartunian, Thin-film thermometer measurements in partially ionized shock tube flows, Phys. Fluids 2, 719.

Paterson, W. L., Chart gives thermal changes of thermistors, Electronics 32, 128 (Oct. 23).

Pies, J. R., New semiconductor for temperature measuring sensistor resistors, ISA Journal 6, 50 (Aug.).
Plumb, H. H., and M. H. Edow, Constant temperature liquid helium bath and reproducibility of resistance thermometers, Rev. Sci. Instr. 30, 376 (May).

Price, R., The platinum resistance thermometer, J. Am. Soc. Naval Engrs. 71, 729.

Sachse, H. B., Thermistors $-10-600^{\circ} \mathrm{K}$, Electronic Ind. 18,81 (Oct.).

Stewart, J. W., Application of indium resistance thermometry, Rev. Sci. Instr. 30, 949 (Oct.).

High-temperature resistance thermometry, Metal Progr. 76, $205 \mathrm{~A}$ (Dec.).

Thermistor thermometer picks out hot spots in drill holes, Eng. Mining J. 160, 120 (Oct.).

\section{0}

Atkins, R. M., Temperature measurements with thermistors, Inst. Control Systems 33, 86 (Jan.).

Rabinowicz, J., and M. E. Jessey, Resistance thermometer for heat transfer measurements in a shock tube, PB 128006 (LC).

Weise, E. K., Alignment chart for the resistance-temperature characteristics of thermistors, PB 133644 (LC).

\section{Radiation Devices}

\section{3}

Brown, D. A. H., et al., Construction of radiation thermocouple using semi-conducting thermoelectric materials, J. Sci. Instr. 30, 195 (June).

Burton, E. J., Recent advances in radiation and immersion pyrometry, Instruments $\mathbf{2 6}, 1524$ (Oct.).

Dike, P. H., Temperature measurements with rayotubes, Leeds and Northrup Co., Philadelphia, Pa.

Heidman, M. F., and R. J. Priem, Application of an electro-optical two color pyrometer to measurement of flame temperature for liquid oxygen-hydrocarbon propellant combination, Nat. Advisory Comm. Aeronaut. Tech. Note 3033; PB 112259.

Herne, H., Theoretical characteristics of bichromatic pyrometers, Brit. J. Appl. Phys. 4, No. 12, 374 (Dec.).

Johnson, I., High temperature radiation galvanometer, PB 114558 (LC) (Aug.).

Millar, G. H., et al., Fast, electro-optical, hot gas pyrometer, J. Opt. Soc. Am. 43, 609 (July).

Radiamatic pyrometers, Mech. Eng. 75, 729 (Sept.).

\section{4}

Carte, A. E., Standard optical pyrometer, S. African J. Sci. 51, No. 5, 136 (Dec.).

Londeree, J. W., Jr., Photographic pyrometry, J. Am. Ceram. Soc. 37, 354 (Aug. 1).

Probene, M. C., and S. Bertaud, Notes on selection of observers for primary standard optical pyrometry, Brit. J. Appl. Phys. 5, No. 6, 227 (June).

Pyatt, E. C., Some considerations of errors of brightness and two color types of spectral radiation pyrometer, Brit. J. Appl. Phys. 5, No. 7, 254 (July).

Sims, R. B., and J. A. Place, Surface scanning pyrometer, J. Sci. Instr. 31, No. 8, 293 (Aug.).

Stoll, A. M., Wide range thermistor radiometer for the measurement of skin temperature and environmental radiant temperature, Rev. Sci. Instr. 25, 184 (Feb.).

Strong, H. M., and F. P. Bundy, Measurement of temperatures in flames of complex structure by resonance line radiation, J. Appl. Sci. 25, No. 12, 1521 (Dec.).

Trout, H. E., Jr., Optical pyrometers, their functioning and maintenance, Steel Processing 40, No. 4, 237 (Apr.).

Optical measurement of temperature, Can. Chem. Processing 38, 66 (Jan.).

1955

Bond, T. E., and C. F. Kelly, Globe thermometer in agricultural research, Agr. Eng. 36, No. 4, 251 (Apr.).

Bracewell, R. A., Infrarèd radiation pyrometer, Electronic Eng. 27, No. 328, 238 (June). 
Elonka, S., Now you can measure heat quickly-at a safe distance, Power 99, No. 12, 116 (Dec.).

Garrison, J. L., Direct measurement of induction heat temperatures with $\mathrm{L}$ and $\mathrm{N}$ rayotube detector, Metal Treating 6, No. 4, 28 (July-Aug.).

Harmer, J. D., and B. N. Watts, Infrared radiation pyrometer, J. Sci. Instr. 32, 167 (May).

Hett, J. H., and J. B. Gilstein, Indicated instantaneous temperatures of liquid rocket exhausts and combustion chambers, Jet Propulsion 25, No. 2, 119 (Feb.).

Kratz, J. H., Radiation pyrometer, J. Franklin Inst. 259, 362 (Apr.).

Land surface pyrometer, Instr. and Automation 28, 1952 (Nov.).

Milliscope pyrometer, Automobile Engr. 45, No. 10, 437 (Oct.).

$\mathrm{New}$ infrared pyrometers determine temperatures at a distance, Ind. Eng. Chem. 47, S $7 \mathrm{~A}$ (Aug.).

Portable pyrometer, Mech. Eng. 7y, 900 (Oct.).

Pyrometer aids jet engine control, Aviation Week 63, 80 (Aug. 8).

\section{6}

Buchele, D., Self-balancing line-reversal pyrometer, Natl. Advisory Comm. Aeronaut. Tech. Note 3656; PB 123515.

Chion, R., Radiation pyrometers for the measurement of transient temperatures, Metaux-Corrosion-Inds. 31, 23 (Jan.).

Derganc, W., and S. N. Howell, Two new total radiation pyrometers, Elec. Eng. 75, 697 (Aug.).

Gergen, J. L., Black ball: A device for measuring atmospheric infrared radiation, Rev. Sci. Instr. 27, 453 (July).

Godridge, A. M., Photoconductive cells for use in radiation pyrometry, Bull. Brit. Coal Utilisation Research Assoc. 20, 349 (Sept.).

Kostkowski, H. J., and H. P. Broida, Spectral absorbtion method for determining population temperatures in hot gases, J. Opt. Soc. Am. 46, 246 (Apr.).

Meyers, V. W., W. D. Walker, and H. S. Stewart, Theory of the behavior of bolometers cooled by gaseous conduction, PB 122757 (LC) (Sept.).

Naeser, G., Improved two color pyrometer and its use, Stahl u. Eisen 76, 968.

Shpiegelman, E. S., Novyi metod posroeniia shkaly opticheskikh pirometrov $\mathbf{v}$ oblasti temperaturi vishe $3000^{\circ} \mathrm{C}$, Izmer. Tekh. 1, 37 (Nov.).

Smit, R., Influence of humidity on measurements with radiation pyrometers, Appl. Sci. Research, Sec. B, 5, No. 6,428 .

Vollmer, J., et al., High speed radiation pyrometer, J. Opt. Soc. Am. 46, 77 (Feb.).

Mapping surface temperatures; Baird Associates Evaporograph gives a direct thermal picture, Chem. Eng. News 34, 1022 (Feb. 27).

\section{7}

Benarie, M. M., Optical pyrometry below red heat, J. Opt. Soc. Am. 47, 1005.

Ricker, C. W., et al., Development of radiation pryometry techniques for measurement of temperature during rolling of uranium, Metal Progr. 71, 148 (Apr.).

Snelleman, W., and J. A. Smit, Photoelectric measurement of flame temperatures by line reversal, Spectrochim. Acta 11, 44.

Sobelov, N. N., and F. S. Faizullov, Photoelectric pyrometer for the measurements of color temperature of flames, Optika i. Spektroskopiya 3, 162.

1958

Birnstingle, D. W., Transitor operated self-balancing radiation pyrometer, Electronic Eng. 30, 189 (Apr.).

Brenden, B. B., and H. W. Newkirk, Multicolor pyrometer, U.S. atomic Energy Comm. HW-57162 Rev.

Brombeck, W. M., R. E. Clemensen, and W. E. Voreck, A recording sodium-line reversal pyrometer, Jet Propulsion $28,249$.
Clouston, J. G., A. G. Gaydon, and I. I. Glass, Temperature measurements of shock waves by spectrum-line reversal method, Proc. Roy. Soc. (London) A252, 429 (Dec. 9).

Crabol, J., and J. Van Kote, Infrared pyrometer for measuring temperatures of turbine blades, Recherche Aeronaut. No. 66 (Sept.).

Davies, M. G., and H. Kronberger, Full radiation pyrometer suitable for temperature measurements in the range $0^{\circ}$ to $100^{\circ} \mathrm{C}, \mathrm{AERE}$ GP/R 272, PB 135020 .

Euler, J., Higher adjusting accuracy with filament pyrometers with contrast plates, Optik 15, 372.

Hariharan, P., and M. S. Bhalla, Precision, direct-reading color temperature meter, J. Sci. Instr. 35, 499 (Dec.).

Kovalerskii, V. A., and L. A. Boiarskii, Objective spectropyrometer SPK-2, Measurement Techniques No. 6, 680.

Lovejoy, D. R., Accuracy of optical pyrometry in the range $800^{\circ}$ to $4000^{\circ}$, Can. J. Phys. 36, 1397.

Mullaney, G. J., Temperature determination in flames by $\mathrm{X}$-ray absorption using a radioactive source, Rev. Sci. Instr. 29, 87 (Feb.).

Murray, T. P., and V. G. Shaw, Two-color pyrometry in in the steel industry, ISA Journal 5, 36 (Dec.).

Ritchey, B. B., Measure fabric temperature with a radiation pyrometer, Textile World 108, 89 (June).

Tingwaldt, C., and H. Kuz, The attainment of black-body radiation at the gold and silver points for pyrometric temperature measurements, Optik 15, 333.

Tourin, R. H., and M. Grossman, Note on monochromatic radiation pyrometer for measuring flame and exhaust gas temperature, Combustion and Flame 2, 330.

\section{9}

Blum, N. A., Recording optical pyrometer, Rev. Sci. Instr. 30, 251 (Apr.).

Brenden, B. B., and H. W. Newkirk, Improved recording multicolor pyrometer, U.S. Atomic Energy Comm. HW600078.

Clouston, J. B., A. G. Gaydon, and I. R. Hurtle, Temperature measurements of shock waves by spectrum-line reversal, Proc. Roy. Soc. (London) A253, 143 (Sept.).

Enslie, A. G., and H. H. Blau, Jr., Measurement of the temperatures of unenclosed objects by radiation methods, J. Electrochem. Soc. 106, 877 (Oct.).

Finkelshtein, V. E., and V. V. Kandyba, Standardization of optical pyrometers, Procès-verbaux séances, Comité intern. poids et measures, Ser. 2, 26A, T142.

Gillham, E. J., Measurement of optical radiation, Research 12, 404 (Oct.).

Glaser, P. E., and H. H. Blau, Jr., A new technique for measuring the spectral emissivity of solids at high temperatures, Trans. Am. Soc. Mech. Engrs. (J. Heat Transfer) $81 \mathrm{C}, 92$.

Gluiberzon, M. E., Fast-acting photoelectric pyrometer, Metallurg. 4, No. 5, 25.

Kirenkov, I. I., Metrological features of color pyrometry, Measurement Techniques No. 1, 33.

Moutet, A., C. Veret, and L. Nadaud, Optical method of measuring the instantaneous temperature of flames, Recherche Aeronaut. No. 68, 9 (Jan.).

Wagenbreth, H., Temperature of a black-body radiator at the Au point, Procès-verbaux séances, Comité intern. poids et mesures, Ser. 2, 26A, T123.

Auto-optic recording pyrometer, J. Franklin Inst. 26\%, 464 (May).

New radiation pyrometer: temperature measurement in induction hardening, Metallurgia 59, 86 (Feb.).

Radiation pyrometer for foundry measurements, Engineer 207, 189 (Jan. 30).

\section{0}

Harrison, T. R., Radiation pyrometry and its underiying principles of radiant heat transfer, John Wiley \& Sons, Inc., New York, N.Y.

Rossler, F., Measurements of flame temperatures, Z. Erzbergbau u. Metallhüttenw. 13, 74. 
Tingwaldt, C., A simple optical-pyrometric method for the direct measurement of the true temperature of incandescent metals, Z. Metallk. 51, 116.

Infrared pyrometer reads engine gas temperature to \pm 20 deg R, S.A.E. Journal 68, 76 (June).

\section{Expansion Devices}

\section{3}

Ackman, A. R., J. McMillan, and A. W. Morrison, Static and dynamic performance of sheathed industrial thermometers, Trans. Soc. Instr. Tech. 5, No. 4, 138 (Dec.).

\section{4}

Faust, F. A., Selection of filled system thermometers, Oil Gas J. 53, 131 (May 17).

Freeze, P. D., and E. F. Fiock, Evaluation of a differentialexpansion temperature sensing device based on critical flow through a variable orifice, U.S. Air Force Wright Air Development Center Tech. Rept. 54-567 (June); PB 119204 (LC).

Muller-Girard, O., Dynamics of filled temperature measuring systems, Am. Soc. Mech. Engrs. M.P. 54-SA-29.

Smith, L. E., Operation of filled system thermometer, Refrig. Eng. 62, No. 11, 40 (Nov.).

Stokes, K. H., and R. C. Whitehead, Ambient temperature errors in gas-filled thermal system for pneumatic-balance instruments, Am. Soc. Mech. Engrs. M.P. 54-A-159.

Industrial filled system thermometers, Mech. World 134, No. 3420, 306 (July).

\section{5}

Linahan, T. C., Dynamic response of industrial thermometers in walls, Am. Soc. Mech. Engrs. M.P. 55-SA-52.

\section{7}

Moser, H., J. Otto, and W. Thomas, High temperature with gas thermometer. I. New gas thermometer method, Z. Physik 147, 59.

\section{8}

Hall, J. A., and V. M. Leaver, Emergent column correction in mercury thermometry, J. Sci. Instr. 35, 93 (Mar.).

Martin, W. I., S. S. Grossman, and J. J. McGnvern, Calibration drift of mercury thermometers repeatedly cooled to $-30^{\circ}$, Am. Soc. Testing Materials Bull. No. 231,62 .

Van Dijk, S., et al., Influence of rate of cooling on the zeros of mercury-in-glass thermometers, J. Sci. Instr. 35, 334 (Sept.).

\section{0}

Solomons, C., and G. J. Janz, A recording Beckman thermometer and differential potentiometer, AFOSR Tech. Note 57-497, ASTIA AD-136 487; PB 129942 (LC).

\section{Aspirated Devices}

\section{1}

Lalos, George T., A sonic-flow pyrometer for measuring gas temperatures, J. Research Natl. Bur. Standards 47, No. 3, 179 (Sept.).

\section{2}

Ruskin, R. E., R. M. Schecter, and others, Development of the NRL Axial-flow vortex thermometer, ASTIA AD-16 694 (Sept.).

Scadron, Marvin D., Analysis of a pneumatic probe for measuring exhaust gas temperature with some preliminary experimental results, Nat. Advisory Comm. Aeronaut. Research Mem. E52A11.

Skelly, E. T., Study to determine characteristics of a vortex type temperature probe, ASTIA AD-625.
Packer, L. S., and Harold C. Box, Vortex free air thermometer, ASTIA AD-38 659.

1954

Cochran, Roy J., Flight tests of two experimental vortex true free air temperature systems, ASTIA AD-29 357 (Mar.).

Land, T., and R. Barber, Design of suction pyrometers, Trans. Soc. Instr. Tech. 6, No. 3, 112 (Sept.).

\section{5}

Beneke, Jack, Development of a miniature vortex free-air thermometer, ASTIA AD-84 572 (Nov.).

Godridge, A. M., R. Jackson, and G. G. Thurlow, Small pneumatic pyrometer, J. Sci. Instr. 32, No. 7, 279 (JuJy).

Owens, G. V., Cloud physics research, investigation of the characteristics of a tangential flow vortex thermometer housing, PB 119443 (LC) (Aug.).

Willshire, D. W., An investigation of the time response of the N.G.T.E. sonic pyrometer, ASTIA AD-91 926 (Nov.).

The vortex tube as a true free air thermometer. Symposium held May 24, 1955 at Armour Research Foundation, Chicago, Illinois, ASTIA AD-90 398 (May).

1956

Glawe, G. E., and F. S. Simmons, Theory and design of a pneumatic temperature probe and experimental results obtained in a high temperature gas stream, Natl. Advisory Comm. Aeronaut. Tech. Note 3893 (Oct.).

Havill, C. D., and L. S. Rolls, A sonic-flow orifice probe for the in-flight measurement of temperature profiles of a jet engine exhaust with afterburning, Natl. Advisory Comm. Aeronaut. Tech. Note 3714; ASTIA AD-93 401.

Land, T., Suction pyrometry, Instr. and Automation 29, 1314 (July).

Land, T., and R Barber, Suction pyrometers in theory and practice, J. Iron Steel Inst. 184, Part 3, 269 (Nov.).

Maulard, J., Standardizing equipment for sonic suction pyrometer, Recherche Aeronaut. No. 49, 27 (Jan.Feb.).

1957

Barber, R., et al., Suction pyrometer for open-hearth furnace uptakes, J. Iron Steel Inst. 185, 343 (Mar.).

Coldren, C. L., and E. W. Comings, Pneumatic thermometer and hygrometer, Chem. Eng. Progr. 53, 403.

Engstrom, R., An air cooled suction pyrometer, Tek. Tidskr. 87, 531 .

Glawe, G. E., A high-temperature combination sonic aspirated thermocouple and total-pressure probe, Jet Propulsion 27, 543 (May).

Kuhns, P. W., Effects of thermal relaxation and specificheat changes on measurements with a pneumatic-probe pyrometer, Natl. Advisory Comm. Aeronaut. Tech. Note 4026.

Riviere, M., G. Urbain, and R. Kissel, Suction pyrometers, Chaleur et Ind. 38, 318.

Thurlow, G. G., Venturi pneumatic pyrometer, Coke and Gas 19, 201.

Urbain, G., and R. Kissel, Aspiration pyrometers, Chaleur et Ind. 38, 389 (Dec.).

\section{8}

Godridge, A. M., et al., Venturi pneumatic pyrometer, J. Sci. Instr. 35, 81 (Mar.).

The measurement of gas stream temperatures in industrial appliances. II. A suction pyrometer for temperatures above $1100^{\circ} \mathrm{C}$, Gas Council (Gt. Brit.), Research Commun. GC 57.

1960

Holland, R. E., R. Jackson, and G. C. Thurlow, Behavior of the venturi pyrometer in industrial furnaces, $J$. Inst. Fuel 33, 180. 


\section{3}

Ambrosio, A., and B. Bussell, Temp-tapes: improved design, construction, and calibration, U.S. Air Force Wright Air Development Center Tech. Rept. 53-211; PB 134779 (LC); ASTIA AD-27 589.

Cowling, J. E., P. King, and A. L. Alexander, Temperature indicating paints, Ind. Eng. Chem. 45, No. 10, 2317 (Oct.).

Hanes, F. S., Jr., Measurement of temperature in explosives, PB 114023 (LC), (Aug.).

Harris, Franklin S., Jr., The measurement of temperature in explosives, ASTIA AD-19 028 (Aug.).

Miller, Paul, Method of measuring surface temperatures in vacuo, ASTIA AD-14 711(b).

Monroe, A. G., and H. A. S. Bristow, Method of measuring the temperature at the surface of a metal tube, J. Sci. Instr. 30, 385 (Oct.).

Potter, Richard D., Phase equilibria studies, a modified method of temperature measurement, ASTIA AD-13 186 (Apr.).

\section{4}

Eastman, Lester F., Measurement of cathode temperature using a retarding potential device, ASTIA AD-57 888(b) (Oct.).

Hoffman, Charles W., Investigations of temperaturedistributions on rocket motors and launchers: Some phosphor methods, ASTIA AD-41 518.

Hogue, E. Walters, Factors affecting the precision and accuracy of an absolute noise thermometer, ASTIA AD-46 864 (July).

Kuhns, P. W., Determination of flame temperatures from 2000 to $3000^{\circ} \mathrm{R}$ by microwave absorption, Natl. Advisory Comm. Aeronaut. Tech. Note 3254.

Livengood, J. C., T. P. Rona, and J. J. Baruch, Ultrasonic temperature measurement in internal combustion engine chamber, J. Acoust. Soc. Am. 26, No. 5, 824 (Sept.).

Lucier, John J., Measurement of peak temperatures with thermal sensitive indicators, ASTIA AD-47 530 (June).

Schweitzer, T. J., R. Kadesch and others, Measurement of compression temperatures in spark-ignition engines, ASTIA AD-52 637 (Aug.).

Tell-tale colors make temperature visible, Steel 135, No. 19,105 (Nov. 8)

\section{5}

Tyroler, Jesse F., Bibliography of methods of measuring the temperature of pyrotechnic flames, ASTIA AD-68 346 (July).

Instantaneous temperature measurements: the development of methods for measuring end-gas temperatures in internal combustion engines, ASTIA AD-78 600.

Yes, you can now use paper thermometers, Safety Maintenance and Production 110, 534 (July).

\section{6}

Dehn, R., new method for measurement of rapid fluctuations of temperature, Brit. J. Appl. Phys. 7, No. 4, 144 (Apr.).

Wolten, G. M., Power engineering handbook; temperature by chemical signal, Power Eng. 60, 96 (May).

First report, high pressure research (Noise thermometer), PB 120667 (LC) (June).

Second report, high pressure research (Noise thermometer), PB 120668 (LC) (June).

\section{7}

Edels, H., and D. Whittaker, The determination of arc temperatures from shock velocities, Proc. Roy. Soc. (London) $\mathbf{A 2 4 0 , 5 4 .}$
Gibson, F. C., M. L. Bowser, et al., Use of an electrooptical method to determine detonation temperatures in high explosives, J. Appl. Phys. 29, 628.

Hoenig, S. A., Use of a constant current hot wire for the measurement of extreme temperatures, Rev. Sci. Instr. 29, 704 (Aug.).

Koch, W., and D. Kaplan, Rhodium-plated katathermometer for measuring true air velocity, J. Sci. Instr. 38, 8 (Jan.).

Livengood, J. C., C. F. Taylor, and P. C. Wu, Measurement of gas temperature in an engine by the velocity of sound method, S.A.E. Trans. 66, 683.

Savet, P. H., On a stationary temperature separating device used as a measuring and cooling/heating apparatus, Abstract, Mech. Eng. 80, 110 (June).

Scott, D. S., Measure gas temperature with a flow meter, Chem. Eng. 65, 161 (Nov.).

Simmons, F. S., and A. G. De Bell, Photographic technique for measuring temperatures in luminous rocket exhaust flames, J. Opt. Soc. Am. 48, 717.

Stow, R. W., Rapid high-sensitivity recording thermometer, Rev. Sci. Instr. 29, 774 (Sept.).

Film tells flame temperature, Chem. Eng. 65, 64 (Jan.).

\section{9}

Cammerer, J. S., Measurement of temperatures and heat quantities by electronic counters, Allgem. Wärmtech. 9, 49 .

Fink, H. J., A new absolute noise thermometer at low temperatures, Can. J. Phys. 37, 1397.

Mouly, R. J., Impedance bridge for surface temperature measurement, Commun. and Electronics, 388 (Summer).

Patrones, E. T., Jr., et al., Low-temperature thermal noise thermometer, Rev. Sci. Instr. 30, 578 (July).

Pursey, H., and E. C. Pyatt, Measurement of equivalent noise resistance of a noise thermometer amplifier, J. Sci. Instr. 36, 260 (June).

Simmons, F. S., and A. G. De Bell, Photographic pyrometry of rocket exhaust jets, Aircraft Eng. 31, 144.

Thureau, P., A method of measuring temperature utilizing the thermal sensibility of fluorescent colors, Publs. sci. et tech. ministere air (France) No. 349.

Townsend, A. A., The analysis of temperature fluctuations by pulse-counting techniques, J. Fluid Mechanics, 261 (Aug.).

I have found a better paint thermometer, Ind. Finishing (Indianapolis) 35, 67 (Feb.).

\section{0}

Burk, D. L., Ratio pyrometer, Instr. Control Systems 33, 64 (Jan.).

Lucier, J. G., Measurement of peak temperatures with thermal-sensitive indicators, PB 130397 (LC).

Moen, W. K., Surface temperature measurements, Instr. Control Systems 33, 70 (Jan.).

Scanlon, W. W., L. G. Mundie, and P. W. Shadle, Temperature measurement with lead sulfide cells, PB 145030 (LC).

\section{Special Applications, Method Not Specified in Title}

\section{3}

Brownlee, A. L., and H. E. Brown, Generator stator copper temperature indicator, Trans. Am. Inst. Elec. Engrs. 72, Part 1, No. 9, 676 (Nov.).

Chenoweth, J. M., et al., Gun barrel measurements involve rapidly fluctuating temperatures, Instruments 26, 1714 (Nov.).

Grunfeld, C., Jr., Instruments for the measurement of local flame temperatures in high velocity streams, PB 122972 (LC); ASTIA AD-17 396. 
Pleuthner, Richard L., and James P. Welsh, Manual of standard temperature measuring techniques, units, and terminology for miniaturized electronic equipment, ASTIA AD-49 485 (June).

Potter, J. H., and R. B. Dillaway, Investigation of flame temperatures in a single cylinder spark ignition engine, Trans. Am. Soc. Mech. Engrs. 75, 1311 (Oct.).

Samberts, K., Temperature measurements in a dielectric field, Abhandl. braunschweig. wiss. Ges. 5, 187.

Werner, F. D., R. E. Keppel, and M. A. Bernards, Design and performance studies for improved multiple-shielded total temperature probes, U.S. Air Force Wright Air Development Center Tech. Rept. 53-194, PB 133014.

\section{4}

Bauserman, G. W., C. H. Prien, and T. Zandstra, Determination of transient flame termperatures, Rev. Sci. Instr. 25, No. 7, 640 (July).

Biancheria, A., and G. Kegeles, Thermodynamic measurements of ultracentrifuge rotor temperature, J. Am. Chem. Soc. 76, No. 14, 3737 (July 20).

Booth, A., Improved methods of temperature indication for a-c generators, Metropolitan-Vickers Gaz. 25, No. 418,257 (May).

Decker, G. E., and R. D. Stiehler, Temperature measurements in Mooney viscosemeter, Am. Soc. Testing Materials Bull. No. 195, 45 (Jan.).

Freedman, R., and E. Burke, Measurement of temperature distribution in a low pressure flat flame, J. Chem. Phys. 22, 824 (May).

Hildenbrand, D. L., A. G. Wittaker, and C. B. Euston, Burning rate studies. Measurement of the temperature distribution in burning liquid strands, ASTIA AD-71 582.

Hudson, D. C., and W. T. Sweeney, Temperatures developed in rotating dental cutting tool, PB 116920 (LC) (Oct.).

Lewis, D. M., Techniques for investigation of thermal conditions in continuous casting, J. Inst. Metals 82, Part 8, 395 (Apr.).

Oriani, R. A., and T. S. Jones, Apparatus for determining solidus temperatures of high melting alloys, Rev. Sci. Instr. 25, No. 3, 248 (Mar.).

Reingold, I. and K. Garoff, Measurement of the gas temperature of a low-pressure if discharge, J. Appl. Phys. 25, 15 (Apr.).

Roberts, L. D., and J. W. T. Dobbs, Production and measurement of temperature below 1K, J. Instr. Soc. Am. 1, No. 10, 25 (Öct.).

Schwartz, Herman, Three temperature probes for measuring ambient air temperatures in clear air and clouds, ASTIA AD-59 679 (Sept.).

Spencer, N. W., et al., Rocket instrumentation for reliable upper-atmosphere temperature determinations, Proc. IRE. 42, 1104 (July).

Tretethers, L., Measurement of mean fluid temperatures, Am. Soc. Mech. Engrs. M.P. 54-A-135.

National Bureau of Standards whirling thermometer takes turbine's temperature, Machine Design 26, 41 (Dec.).

Remote indication of turbine blade temperature, Automotive Inds. 111, 71 (Dec. 15).

Turbine-blade temperature telemeter, Instr. and Automation 27, No. 12, 1958 (Dec.).

\section{5}

Baker, D. I., Mixture ratio and temperature survey of ammonia-oxygen rocket motor combustion chambers, Jet Propulsion 25, No. 5, 217 (May).

Dahl, A. I., Probe for steam temperature measurements, J. Instr. Soc. Am. 2, No. 4, 108 (Apr.).

Evans, J. C., It takes rugged instruments to measure 325 degrees below zero, Oil Gas J. 53, No. 47, 123 (Mar. 28).

Garvitch, Z. S., Field instrument for measuring temperature of natural boiling pools, J. Sci. Instr. 32, No. 7, 261 (July).
Gerbitz, D. D., and J. S. Ewing, Correlation of temperature measurements on $\mathrm{d}-\mathrm{c}$ armatures, Trans. Am. Inst. Elec. Engrs. 74, Part 3, No. 18 (June).

Giedt, W. H., Determination of transient temperatures and heat transfer at gas-metal interface applied to $40 \mathrm{~mm}$ gun barrel, Jet Propulsion 25, No. 4, 158 (Apr.).

Goodall, A., Open-hearth immersion pyrometers, J. Iron Steel Inst. 180, Part 3, 247 (July).

Greene, C. R., Temperature profiles throughout cigarettes, cigars, and pipes, Science 122, 5145 (Sept. 16).

Koletsky, H., Temperature indicator for aircraft engines, Electronics 28, 129 (Nov.).

Pease, R. S., Measurement of specimen temperatures in a high temperature X-ray powder camera, J. Sci Instr. 32, 476 (Dec.).

Swenson, C. A., R. H. Stahl, and others, Measurement and control of low temperatures, ASTIA AD-82 757.

Willman, B. T., J. E. Brock, W. L. Sibbitt, and G. A. Hawkins, Measurement of gun barrel temperatures, Instr. and Automation 28, No. 1, 106 (Jan.).

Best way to measure tube temperature? Power 99, 138 (Apr.).

Steam temperature measurements, Elec. J. 155, 2089 (Dec. 23).

\section{6}

Belansky, A. M., and C. F. Peck, Jr., Roll temperature study on hot strip mill, Iron Steel Engr. 33, 62 (Mar.).

Cushman, R., Cornell instruments for shock tubes, Aviation Week 65, 255 (Oct. 29).

Fink, R., Checking and recording metal temperatures, Foundry 84, No. 6, 142 (June).

Grosh, R.J., and E. A. Trabant, Arc welding temperatures, Welding J. (N.Y.) 35, S396 (Aug).

Lucas, D. H., and M. E. Peplow, Measurement of steam temperatures in power stations, Proc. Inst. Elec. Engrs. (London) 103, Part A (Apr.).

Pavlides, P. K., In-service temperature measurement of the amortisseur windings of large frequency changers, Elec. Eng. 75, 1091 (Dec.).

Rickey, G. G., et al., Temperature studies of the air in a truck tire, Rubber Age 79,273 (May).

Device measures $400,000^{\circ}$ F, J. Franklin Inst. 261, 682 (June).

\section{7}

Gill, T. P., Some problem in low-temperature pyrometry, J. Opt. Soc. Am. 4y, 1000.

Halsall, J. R., Some aspects of process control instrumentation, J. Brit. Inst. Radio Engrs. 17, 551.

Sachse, H. B., Temperature measurements near absolute zero, Electronic Inds. Tele-Tech 16, 58 (Sept.).

West, W. C., Jr., Ways to control temperature accurately and economically, Precision Metal Molding 15, 79 (Nov.).

\section{8}

Clark, D. D., Thermometer for high-speed aircraft, J. Sci. Instr. 35, 433 (Dec.).

Flanigan, F. M., and J. O. Gonzales, Transient temperature sensing equipment, PB 132106 (LC).

Giedt, W. H., Temperature measurements in solids, Product Eng. 29, 65 (July 21).

Hall, J. G., and A Hertzberg, Recent advances in transient surface temperature thermometry, Jet Propulsion 28, 719.

Henshaw, D. H., and D. F. Daw, Design of total temperature probes, PB 126980 (LC).

Hett. J. H., Measurement of temperatures of pulsating burning gases, PB 131861 (OTS).

Krause, L. N., R. C. Johnson, and G. E. Glawe, A cooledgas pyrometer for use in high temperature gas streams, Natl. Advisory Comm. Aeronaut. Tech. Note 4383.

Neher, I. E., Determination of temperature in hightemperature, high velocity gases, Arch. tech. Messen Lfg. 270, 133.

Rothe, C. F., Simple surface thermometer, Rev. Sci. Instr. 29, 436 (May). 
Sanders, V. D., Review of high-temperature, immersion thermal sensing devices for in-flight control, Rev. Sci. Instr. 29, 917 (Nov.).

Warshawsky, I. Measurements of rocket exhaust-gas temperatures, ISA Journal 5, 91 (Nov.).

Werner, T. D., Total temperature measurement, Abstract, Mech. Eng. 80, 110 (June).

\section{9}

Culpin, M. F., and D. M. Jones, Measurement of the temperature of a running thread line, J. Sci. Instr. 36, 22 (Jan.).

Kennedy, R. H. Tunnel kiln temperature.measurement, Am. Ceram. Soc. Bull. 38, 45 (Feb.).

Kitchen, B. G., Precise measurement of process temperature differences, ISA Journal 6, 39 (Feb.).

Krause, L. N., et al., Cooled-gas pyrometer for use in high-temperature gas streams, Control Eng. 6, 185 (Mar.).

Pattison, J. R., Ingot surface-temperature measurement in forging furnaces, J. Iron Steel Inst. (London) 191, 163 (Feb.).

Pattison, J. R., Ingot surface-temperature measurement in induction hardening, Metallurgia 59, 86 (Feb.).

Sandlin, B. J., and J. C. Thompson, Precision thermometer system for the liquid helium region, Rev. Sci. Instr. 30, 659 (Aug.).

Sebulkin, M., Total-temperature probe for high-temperature boundary-layer measurements, J. Aero/Space Sci. 2C, 458 (July).

\section{Nuclear Applications of Temperature Measurement}

\section{5}

Barbaras, G., et al., Design and construction of boron coated thermopiles for use in neutron fields, U.S. Atomic Energy Comm. AECD-2975, Univ. of Chicago (Feb.).

\section{7}

LaGraff, J. Modifications in compound 10 couple copperconstantan thermocouple used for determination of hydrogen fluoride in uranium hexafluoride, U.S. Atomic Energy Comm. K-106 (OTS) (Dec.).

\section{9}

Barbaras, G., J. Farr, and J. Kuranz, Design and construction of boron coated thermopiles for use in neutron fields, U.S. Atomic Energy Comm. AECD-2985 (OTS) (Feb.).

\section{0}

Wilkinson, P. E., and G. O. Whitman, High temperature ion source and Thermohn development for stable isotope production, U.S. Atomic Energy Comm. Y-705 (OTS) (Dec.).

\section{4}

Thermocouple developed for nuclear reactor, Elec. World 142,130 (July) 12.

Thermocouple for atomic reactors, Materials and Methods 40, 226 (July).

Thermocouple measures temperatures in nuclear reactor, Iron Age 173, 170 (May 6).

\section{6}

Replogle, F. S., Jr., Stacked-disk neutron thermopile, PB 120026 (LC) (June).

Yockez, Y. P., Use of thermocouples in a radiation field, Phys. Rev. 101, 1426 (Feb. 15).

Annual progress report under contract N5 ORI-07876, NR 025-164 M.I.T. (Neutron Sensitive Thermopile and Assoc. Equip.), PB 119650 (LC) (June).
Cohen, P., Reliability of PWR fuel element thermocouples at high $\mathrm{pH}$ with $\mathrm{LiOH}$, Westinghouse At. Power Division Rept. WAPD-CDA-126 (Dec.).

F. R. Sias, Resistance thermometer for nuclear-reactor service, Nucleonics 15, No. 8, 75 .

\section{8}

Palladino, N. J., PWR seed metal thermocouples, Westinghouse At. Power Division Rept. WAPD-PWR-RD 603 (May).

\section{9}

De Lorenzo, J. T., Thermocouple design and test program for reactor projects, Oak Ridge National Laboratory Rept. ORNL-2686 (May).

\section{Associated Equipment and Testing Procedure}

\section{3}

Bailey, C. M., Jr., and A. I. Dahl, Vibration tests of thermocouples, U.S. Air Force Wright Air Development Center Tech. Rept. 53-340, PB 134797 (LC)

Dahl, A. I., and E. F. Fiock, Circuitry errors of laddertype thermocouple-harness assemblies, U.S. Air Force Wright Air Development Center Tech. Rept. 53-4, PB 135243 (LC).

\section{4}

Higgins, S. P., and J. R. Kein, Thermal sine wave apparatus for testing industrial thermometers, Am. Soc. Mech. Engrs. M.P. 54-SA-20.

Looney, R., Thermal sine wave generator for speed of response studies, Am. Soc. Mech. Engrs. M.P. 54-SA28.

Lytle, E. A. L., A portable potentiometer for measuring the emfs of thermocouples, ASTIA AD-50 058 (Oct.).

Sherman, A., Thermocouple circuit restorer, Instr. and Automation 27, No. 1, 124 (Jan.).

Welch, J. H., Simple microscope attachment for observing high-temperature phenomena, J. Sci. Instr. 31, No. 12, 458 (Dec.).

\section{5}

Jones, D. H., Device improves thermocouple pyrometer operation, Iron Age 176, 108 (Dec. 15).

Kauffman, A. B., Telemetered temperatures, Instr. and Automation 28, No. 8, 1320 (Aug.).

Walter, L., Pyrometry-some suggestions for maintenance, Steel Processing 41, 435 (July).

Thermophil thermometer; portable electronic instrument, Automobile Eng. 45, 459 (Nov.).

\section{6}

Malmberg, P. R., and C. G. Matland, Thermistor temperature control, Rev. Sci. Instr. 27, 136.

Morris, P. R., Inductance-type thermocouple tester, Instr. and Automation 29, 2217 (Nov.).

Premak, W., Gouy modulator for thermocouples, Rev. Sci. Instr. 27, 877 (Oct.).

Robertson, G. R., Design and operation of a thermometer comparator, J. Chem. Educ. 33, 40 (Jan.).

Zeffert, D. M., and R. E. Witherspoon, Thermistor temperature recorder, Anal. Chem. 28, 1701.

\section{7}

Proctor, C. M., Principles of laboratory temperature control, PB 121120 (OTS) (May).

Stainless steel collector ring for exhaust gas thermocouples, Machinery (N.Y.) 63, 159 (Aug.); J. Franklin Inst. 264, 300. 
Durgin, G. E., Tester checks thermocouples without flame' ISA Journal 5, 57 (Mar.).

Gordov, A. N., et al., New equipment for checking heatpower instruments, Measurement Techniques No. 6, 674.

Hermach, F. L., Definition and measurement of the time constant and response time of thermal converters, Commun. and Electronics, 277 (July).

Morphew, K. L., The performance of thermally inert metal blocks as cold junction enclosures for thermocouples, Elec. Energy 2, 172 (May).

Robinson, W. M., and F. H. Allen, Flange-inserted thermowell easy to install, Chem. Eng. 65, 125 (Dec.).

Roeser, W. F., and S. T. Lonberger, Methods of testing thermocouples and thermocouple materials, Nat. Bur. Standards (U.S.) Cir. No. 590 (Feb.).

Trigger, K. J., R. K. Campbell, and B. T. Chao, A toolwork-thermocouple compensating circuit, Trans. Am. Soc. Mech. Engrs. 80, 302.

Ziegler, J., Thermocouple compensating using a thermistor, Australian J. Instr. Technol. 14, 146.

\section{9}

Burwen, R. S., Amplifiers for strain gages and thermocouples, Electronics 32, 43 (July 24).

Dickinson, T. A., Soldering Chromel and Alumel wire, Wire and Wire Products 34, 469 (Apr.).

Lovejoy, D. R., H. J. Kostkowski, H. Kunz, and H. Wagenbreth, Standardization of W-filament lamps, Procès-verbaux séances, Comité intern. poids et mesures, Ser. 2, 26A, T133.

Specht, H., Apparatus for the welding of thin thermocouples, Z. Metallk. 50, 36 (Jan.).

Tramposch, H., et al., Rapid scanning system for recording thermocouple outputs, ASTM Bull., 41 (May).

Improved thermal, electrical layout ups radiation pyrometer accuracy, stability, Machine Design 31, 134 (Oct. 1).

Sleeve guards thermocouple against thermal shock, Steel 144, 89 (June 22).

\section{0}

Bochkov, F. V., Study of the properties of protective . shields for thermocouples, Ogneupory 25, 39.

\section{General}

\section{0}

Baker, H. D., Manual on thermometry; with emphasis on thermocouple techniques, United Aircraft Corp., East Hartford.

Weber, R. L., Heat and temperature measurement, Prentice Hall, New York, N.Y.

\section{1}

Campbell, C. H., Modern pyrometry, Chemical Publ. Co., New York.

Freeze, Paul D., Bibliography on the measurement of gas temperature, Nat. Bur. Standards (U.S.) Cir. 513 (Aug. 20).

\section{3}

Baker, H. D., E. A. Ryder, and N. H. Baker, Temperature measurement in engineering, Vol. I, John Wiley \& Sons, Inc., New York, N.Y.

Burton, E. J., and D. J. Weeks, Temperature measurement, J. Inst. Fuel 26, No. 154, 260 (Nov.).

\section{4}

Belcher, W. E., Jr., Donald Robertson, and W. F. Hicks, Temperature measurements, Am. Soc. Metals (Oct.).

Keonjian, E., and J. S. Schaffner, Shaping characteristics of temperature-sensitive elements, Trans. Am. Inst. Elec. Engrs. 73, Part 1, No. 14, 396 (Sept.).
Barry, H., Temperature measuring instruments, Meta] Ind. (N.Y.) 86, No. 25, 537 (June 24).

Clement, J. R., J. K. Logan, and J. Faggney, An examination of the 1948 liquid helium vapor pressure-temperature scale, ASTIA AD-62 277 (May).

Leon, K. S., and W. L. Harries, Temperature transducers PB 121296 (OTS) (June).

Temperature, its measurement and control in science and industry, American Inst. of Physics, Reinhold Publ. Corp., New York, N.Y., Vol 1-1941; Vol 2-1955.

1956

Ambler, E., and R. P. Hudson, Examination of the helium vapor-pressure scale of temperature using a magnetic thermometer, J. Research Nat. Bur. Standards 56, 99 (Feb.).

Finkelstein, V. E., E. S. Shpiegelman, and V. V. Kandyba, Pirometry EOP-51M i OP-48M dlia izmereniia temperatury do $6000^{\circ} \mathrm{C}$, Zemer. Tekh. 1, 52 (Sept.).

Godridge, A. M., R. Jackson, and G. G. Thurlow, Industrial measurements of gas temperature, Trans. Soc. Instr. Tech. 8, 103 (Sept.).

Herzfeld, C. M., A study of basic limitations to the concept and measurement of temperature; incomplete equilibrium, ASTIA AD-85 386 (Jan.).

Kandyba, V. V., Instruments for accurate measurement of high temperature, Izmer. Tekh. 1, 36.

Land, T., Recent developments in temperature measurement and control, Met. Rev. 1, Part 2, 271.

Lindorf, H., Technical temperature measurements, Verlag W. Girardet, Essen, Germany.

Panel discussion on pyrometric practices, Am. Soc. Testing Materials-Special Tech. Pub. No. 178.

British pyrometer progress, Brit. Steelmaker 22, No. 12, 358 (Dec.).

\section{7}

Beede, H. M., High-temperature measurements of gas streams in turbo-machinery, Instr. and Automation 30, 1896.

Moreau, H., J. A. Hall, and V. M. Leaver, Mercury in quartz thermometers for very high accuracy, J. Sci. Instr. 34, 147.

Oughton, H. G., Primary elements for temperature measurement, Instr. Engr. 2, 76 (Oct.).

Warshawsky, I., Pyrometry of high velocity gases, Sixth Symposium (International) on Combustion, New Haven, Connecticut, Reinhold Pub. Corp., New York, N.Y. (1957), p. 739.

\section{8}

Farber, E. A., Methods and systems used for temperature measurement, Air Conditioning, Heating and Ventilating 55, 76 (July).

Hall, J. A., Accurate measurement of temperature, Research 11, 147 (Apr.).

Herzfeld, C. M., New high-temperature measuring techniques at National Bureau of Standards, Control Eng. 5, 30 (Nov.).

\section{9}

Bingham, C. R., Temperature detectors, Electronics 32, 55 (July).

Foskett, A. C., Thermocouples for high temperature measurement (a bibliography), United Kingdom Atomic Energy Authority, AERE-Bib. 125.

Humphreys, J. D., Radiation shielded thermometer design, Electronic Inds. 18, 102 (Mar.). 



\section{Bibliography of Temperature Measurement July 1960 to December 1962}

Carl Halpern 


\title{
Bibliography of Temperature Measurement
}

\author{
July 1960 to December 1962
}

\author{
Carl Halpern
}

(May 9, 1963)

\begin{abstract}
There are presented in this supplement to NBS Monograph 27, "Bibliography of Temperature Measurement, January 1953 to June 1960" issued April 6, 1961, about 700 additional references to the field of temperature measurement. The period covered is from July 1960 to December 1962 with some earlier references which came to our attention. The arrangement of material is the same as in Monograph 27, and the journal abbreviations used are those employed in Chemical Abstracts.
\end{abstract}

\section{Introduction}

The material contained herein was collected from two general sources: scientific and technical journals and reports of investigations sponsored or conducted by various governmental agencies. English, German, and French journals and translations in English of Russian journals were covered as well as the more commonly used abstract journals. Some references to material in other languages, obtained from the abstract journals, are also included. To obtain references to governmental reports the following were consulted: Technical Abstract Bulletin, Armed Services Technical Information Agency (ASTIA); U.S. Government Research Reports, Office of Technical Information, U.S. Department of Commerce; and Scientific and Technical Aerospace Reports, National Aeronautics and Space Administration (NASA). While reasonably complete coverage was intended, it is inevitable that oversights and other unintentional omissions have occurred.

\section{Thermoelectric Theory and Calibration}

$$
1950
$$

Barber, C. R., The emf-temperature calibration of $\mathbf{P t}$, $10 \% \mathrm{Rh}$ Pt and Pt, 13\% Rh Pt thermocouples over the temperature range $0-1760^{\circ} \mathrm{C}$, Proc. Phys. Soc. (London) 63B, 492.

\section{8}

Aikhenbaum, B. L., Changes in the testing system in the field of temperature measurement, Measurement Techniques No. 5, 547 (Sept.-Oct.).

Kurti, N., The absolute temperature scale at low temperatures, Z. Physik. Chem. (Frankfurt) 16, 281.

\section{9}

Astrov, D. N., A. S. Borovik-Romanov, M. P. Orlova, and P. G. Strelkov, Evolving a practical temperature scale in the region of $10-90^{\circ} \mathrm{K}$, Measurement Techniques No. 11,876 (Nov.).
Astrov, D. N., M. P. Orlova, P. G. Strelkov, and D. I. Sharevskaya, Comparison of low-temperature scales of platinum resistance thermometers, Measurement Techniques No. 8, 613 (Aug.).

Barber, C. R., New gas thermometer measurements over the range from $10^{\circ}$ to $90^{\circ} \mathrm{K}$ and the extension of the International Temperature Scale below $90^{\circ} \mathrm{K}$, Proc. Intern. Congr. Refrig., 10th, Copenhagen, 1959, 1, 174.

Bragin, B. K., A thermoelectric method of evaluating the purity of platinum for standard thermocouples, Measurement Techniques No. 10, 776 (Oct.).

Dzyuba, A. S., and P. B. Kantor, A semiconductor thermocryostat for calibration of standard thermometers, Measurement Techniques No. 11, 880 (Nov.).

Gertsriken, S. D., M. M. Novikov, and V. S. Kopan, Nature of the thermal electromotive force that arises from metal deformation, Ukrain. Fiz. $\mathrm{Zh} .4,293$.

Kropschot, R. H., and F. J. Blatt, Thermoelectric power of cold-rolled pure copper, Phys. Rev. 116, 617.

Orlova, M. P., Reproducibility of the boiling temperature of oxygen, Measurement Techniques No. 5, 330 (May).

Pilipchuk, B. I., Units for the measurement of thermal quantities, Measurement Techniques No. 1, 26 (Jan.).

Swindells, J. F., Calibration of liquid-in-glass thermometers, Natl. Bur. Std. (U.S.) Circ. 600.

Usoltsev, V. A., Stability of the distillation temperature of carbon dioxide, Measurement Techniques No. 2, 118 (Feb.).

Yayshev, N. A., Approximation theory of the heat inertia of technical thermocouples and resistance thermometers, Nauch. Trudy Leningrad. Inst. Tochnoi Mekh. i Optiki 1959, No. 37, 64-90.

\section{0}

Berry, R. J., The reproducibility of the sulfur point, Can. J. Phys. 38, 1027 (Aug.).

Blatt, F. J., M. Garber, R. H. Kropschot, and B. Scott, Thermoelectric power of dilute copper and silver alloys, Australian J. Phys. 13, 223.

Blatt, F. J., and R. H. Kropschot, Thermoelectric power of dilute copper alloys, Phys. Rev. 118, 480.

Boerdijk, A. H., Diagrams representing states of operation of a general thermocouple, J. Appl. Phys. 31, 1141 (July).

Borovik-Romanov, A. S., M. P. Orlova, and P. G. Strelkov, Designing a practical temperature scale for the $10-90^{\circ} \mathrm{K}$ interval, Measurement Techniques No. 1, 42 (Jan.).

Bragin, B. K., Calibration of rare-metal thermocouples against the melting point of palladium, Measurement Techniques No. 12, 1019 (Dec.). 
Brickwedde, F. G., H. van Dijk, M. Durieux, J. R. Clement, and J. K. Logan, The "1958 $\mathrm{He}^{3}$ scale of temperatures," J. Res. Natl. Bur. Std. (U.S.) 64A, 1; Natl. Bur. Std. (U.S.) Monograph 10 (June 17).

Corruccini, R. J., Interpolation of platinum resistance thermometers, Rev. Sci. Instr. 31, 673 (June).

Costa, P., Determination of the thermoelectric power of uranium and plutonium, J. Nucl. Mater. 2, 75.

Danisherskii, S. K., Selection and calibration of tungsten and molybdenum wire for thermocouples, Measurement Techniques No. 5, 333 (June).

Donahoe, F. G. Theoretical bound on the thermoelectric figure of merit, Elec. Eng. 79, 488 (June).

Donde, Yu. Ya., and M. A. Pisarevskaya, The use of alternating currents for calibration commercial optical pyrometers, Measurement Techniques No. 9, 766 (Sept.)

Fink, E. W., An infrared radiation method for calibrating transient thermocouples, Westinghouse Electric Corp., Bettis At. Power Lab., Pittsburgh, WAPD-R (TH) -575 (Apr.).

Harrison, W. N., et al., Standardization of thermal emittance measurements, WADC Tech. Rept. 59-510, Pt I and II (Aug. 1959 and Nov. 1960).

Heusinkveld, W. A., Comparison of the temperature scales of various laboratories in the $600-3500^{\circ} \mathrm{C}$ range, Electrotechniek 38,536 (Oct.).

Hughes, W. F., and E. W. Gaylord, Theoretical analysis of a dynamic thermocouple. II. The continuous area interface, J. Appl. Mech. 27, 259.

Kaufman, A. B., Temperature-probe response time, Instr. Control Systems 33, 804 (May).

Kirenkov, I. I., New thermodynamic temperature measurements of solidifying gold and zinc, Measurement Techniques No. 6, 493 (June).

Kirenkov, I. I., V. A. Kovalevskii, and G. A. Krakhmalnikova, Reproduction of the color-temperature scale by photometric methods, Measurement Techniques No. 2, 112 (Feb.).

Lewis, H. W., and J. R. Reitz, Efficiency of the plasma thermocouple, J. Appl. Phys. 31, 723.

Lougher, E. H., Measurement of the parameters in the thermoelectric figure of merit, Elec. Eng. 79, 358 (May).

McLaren, E. H., and E. G. Murdock, The freezing points of high purity metals as precision temperature standards, Can. J. Phys. 35, 1086 (1957) ; 36, 585, 1131 (1958) ; $38,100,577(1960)$.

MeNish, A. G., Temperature standards, Instr. Control Systems 33, 775 (May).

Meyer, G., and J. F. Oosterom, Calibration of millivoltmeters and thermoelements and the combination of the two, Rec. Trav. Chim. 79, 622.

Müller, R. H., New precise temperature standard, Anal. Chem. 32, 123A (Sept.).

Myers, W. C., and R. T. Bate, Measure of figure of merit of thermoelectric materials, Rev. Sci. Instr. 31, 464 (Apr.).

Pearson, W. B., The thermoelectric power of annealed and cold-worked silver and gold at low temperature, Can. J. Phys. 38, 1048.

Pearson, W. B., Interpretation of relative thermoelectric phenomena at low temperature with special consideration of the effects of cold work on copper, Phys. Rev. 119,549 .

Plyukhin, B. I., Laws of the temperature radiation of a flame, Dokl. Akad. Nauk SSSR 131, 68.

Quandt, Jr., E. R., and E. W. Fink, Experimental and theoretical analysis of the transient response of surface-bonded thermocouples, U.S. At. Energy Comm. WAPD-BT-19.

Roeser, W. F., Calibrating thermocouples, Instr. Control Systems 33, 796 (May).

Schindler, A. I., and R. J. Smith, Low temperature dependence of the electrical resistivity and thermoelectric power of palladium and palladium nickel alloys containing absorbed hydrogen, PB 146217 (LC) (Oct.).

Sharevskaya, D. I., and P. G. Strelkov, Thermometric platinum resistivity in the region of liquid helium temperatures, Measurement Techniques No. 12, 1023? (Dec.).

Sharevskaya, D., et al., Differences in the relation between resistance and temperature of several grades of platinum in the range of 10.8 to $273.16^{\circ} \mathrm{K}$, Measurement Techniques No. 7,598 (July).

van Dijk, H., The 1958 scale of temperatures for the liquid helium-4 region, Progr. Cryog. 2, 121.

Williams, S. B., Triple-point-of-water temperature reference, Instr. Control Systems 33, 1918.

Wilson, R. E., Temperature standards, Instr. Control Systems 33, 770 (May).

Temperature calibration survey, Instr. Control Systems 33, 778 ( May).

\section{1}

Bauerle, L. E., Analysis of "immersed" thermocouple error, Rev. Sci. Instr. 32, 313 (Mar.).

Boerdijk, A. H., Zero-, first-, and second-order theories of a general thermocouple, J. Appl. Phys. 32, 1584 (Aug.).

Bowley, A. E., et al., Measurement of the figure of merit of a thermoelectric material, J. Sci. Instr. 38, 433 (Nov.).

Bragin, B. K., A normal platinum thermal electrode, Measurement Techniques No. 7, 596 (Feb.).

Bragin, B. K., Certain errors in checking commercial resistance thermometers, Measurement Techniques No. 3, 194 (Mar.).

Bragin, B. K. Errors in the calibration of technical resistance thermometers, Izmeriteln. Tekhn. No. 3, 17.

Crawford, G. J. B., Note on the measurement of the figure of merit of thermoelectric materials and of refrigerating junctions, Rev. Sci. Instr. $32,353$.

Gordov, A. N., and B. I. Kovshev, Nature of dynamic errors in measuring pulsating temperatures of a gas flow with a pulsating speed, Measurement Techniques No. 5, 363 (May).

Haas, A., Calibration of contact surface thermometers, Acta Imeko, 91.

Haase, R., K. Hoch, and H. Schouert, Thermocouples. VI. Evaluation of the measurements, Z. Physik. Chem. (Frankfurt) 27, 421

Jones, T. P., On the accuracy of realization of the international temperature scale above $1063^{\circ} \mathrm{C}$, Australian J. Appl. Sci. 12, 141 (June).

Kennedy, G. C., and R. C. Newton, Effect of pressure on the electromotive force of a platinum-bismuth thermocouple, J. Geophys. Res. 66, 1491.

Krikorian, O. H., Optical pyrometer calibration with a standard carbon arc, Proc. Instr. Soc. Am. 16, Paper No. 151-LA-61.

Madison, J. H., Calibration of Chromel-Constantan thermocouples for nuclear heat rate sensors, General Electric Co., Aircraft Nucl. Propulsion Dept., Cincinnati, TID-11927 (Jan. 23).

Maulard, J., The theoretical determination of the response time of a thermometric probe, Rech. Aeron. No. 83, 41 (July).

Moser, H., Thermodynamic temperature scale, its realization between $90^{\circ}$ and $1500^{\circ} \mathrm{K}$, Pure Appl. Chem. 2, 167.

Oleinik, B. L., New regulations on the international practical temperature scale, Measurement Techniques No. 7, 538 (July).

Orshanskii, D. L., On very high temperatures, the physical basis of their concept and their measurement, Acta Imeko, 136.

Prinz, W., Indication delay and indication error functions of thermometers. The significance of the half value time and nine tenths value time of thermometers, Allgem. Wa ermetech. 10, 85 .

Reich, A. D., and J. R. Madigan, Transient response of a thermocouple circuit under steady currents, J. Appl. Phys. 32, 294 (Feb.)

Roy, J., and G. Gohard, "Fixed point" apparatus for thermocouple calibration, Mesur. Control Ind. 26, 269 (Mar.). 
Sharevskaya, D. I., and P. G. Strelkov, Methods for calibrating against the practical temperature scale in the region of $10-90^{\circ} \mathrm{K}$, Measurement Techniques No. 2, 110 (Feb.).

Shpiegelman, E. S., Utilization of aluminum for calibrating first-grade thermometers, Measurement Techniques No. 5,405 (Jan.).

Stimson, H. F., International practical temperature scale of 1948. Text revision of 1960 , Natl. Bur. Std. (U.S.) Monograph 37 (Sept. 8).

Stimson, H. F., International practical temperature scale of 1948, J. Res. Natl. Bur. Std. (U.S.) 65A, 139.

Suzuki, M., Temperature standard below an oxygen point, Res. Electrotech. Lab., Tokyo, No. 615 (Sept.).

Tingwaldt, C., Thermodynamic temperature scale, its realization in solid bodies for temperatures above $1500^{\circ}$. K, Pure Appl. Chem. 2, 173.

Toenshoff, D. A., Automatic calibration of thermocouples, Engelhard Inds. Tech. Bull. 2, 88 (Dec.).

van Dijk, H., The thermodynamic temperature scale and its realization below $90^{\circ} \mathrm{K}$, Pure Appl. Chem. 2, 157. Wagner, N. K., Theoretical time constant and radiation error of a rocketsonde thermistor, J. Meteorol. 18, 606 (Oct.).

Calibration of optical pyrometers, Glass Ind. 42, 638 (Nov.).

Calibration of optical pyrometers, Natl. Bur. Std. (U.S.) Tech. News Bull. 45, 184 (Nov.).

Calibration of optical pyrometers, Instr. Pract. 15, 1558 (Dec.).

Calibration of platinum resistance thermometers, Engineer 211, 1048.

Calibration of platinum resistance thermometers, Instr. Pract. 15, 863 .

Calibration of platinum resistance thermometers, Natl. Bur. Std. (U.S.) Tech. News Bull. 45, 62 (Apr.).

How to calibrate thermocouples to high accuracies, Space/ Aeronauties 35, 89 (May).

Ice point standardization mercury-in-glass thermometers, $\mathrm{Bu}$ Weps-Bu Ships Calibration Program, Secondary standards laboratory measurement system operation procedure, NT-01, PB 171725.

The international practical temperature scale, Natl. Bur. Std. (U.S.) Tech. News Bull. 45, 65 (Apr.).

Thermocouple calibration, Natl. Bur. Std. (U.S.) Tech. News Bull. 45, 44 (Mar.).

Thermocouple calibration, Electron. Ind. 20, 231 (Mar.).

Thermocouple calibration, Instr. Pract. 15, 428 (Apr.).

Thermocouple calibration, Instr. Control Systems 34, 1663 (Sept.).

Triple point of water standardization, Bu Weps-Bu Ships Calibration Program, Secondary standards laboratory measurement system operation procedure NT-04, PB 171726.

\section{2}

Barber, C. R., The establishment of a practical scale of temperature for the range $10-90 / K$, Brit. J. Appl. Phys. 13, 235 (May).

Berry, R. J., A precision oxygen point calibration bath, Can. J. Phys. 40, 859 (July)

Blackburn, G. F., and F. R. Caldwell, Reference tables for 40 percent iridium-60 percent rhodium versus iridium thermocouples, J. Res. Natl. Bur. Std. (U.S.) 66C, $\mathbf{J}$ (Jan.-Mar.)

Bussard, R. W., Some considerations of dynamic behavior in the plasma thermocouple, J. Appl. Phys. 33, 606 (Feb.).

Davis, J., and G. Lanza, Conventional and plasma thermoCouples, U.S. Air Force, Office of Aerospace, Res, AFCRI 62-630 (June 5).

Freeze, P. D., F. R. Caldwell, and E. R. Davis, Reference tables for the palladium $\nabla$ s platinum-15 percent iridium thermocouple, ASD-TDR-62-525 (Dec.); ASTIA AD295607.

Kelly, G. D., How to calibrate optical pyrometers, Ceram. Ind. 79,64 (Oct.).
Krikorian, O. K., Optical pyrometer calibration with a standard carbon arc, ISA Trans. 1, 273 (July).

Lovejoy, D. R., Temperature scales above $1000^{\circ} \mathrm{C}$, Pure Appl. Chem. 5, 565.

Myers, H. S., Convenient laboratory temperature standard, Chem. Eng. 69, 192 (Mar.).

Obrowski, W., and W. Prinz, Determination of basic values for the thermocouples Pt 30\% Rh-Pt 6\% Rh, Arch. Eisenhuettenw. 33, 1.

Thorn, R. J., and G. H. Winslow, Contribution to the realization of the visual optical pyrometer temperature scale, Rev. Sci. Instr. 33, 961 (Sept.).

Zholkov, Yu. A., Thermal inertia of thermocouples, Measurement Techniques No. 12, 938 (June).

Calibration of optical pyrometers, Instr. Control Systems 35,84 (May).

Reference tables for iron $\nabla$ constantan thermocouples, Brit. Std. Inst., B. S. 1829.

The thermodynamic and practical temperature scales, $\mathrm{R} \& \mathrm{D}$ No. 15,40 (Nov.).

\section{Thermoelectric Devices}

\section{9}

Steven, G., and W. C. Troy, The mechanical protection of the W/Ir thermocouple, PB 138320 (LC), (June).

1950

Steven, G., and W. C. Troy, The development of thermocouples for temperatures in the region of $1600^{\circ}$ to $2000^{\circ} \mathrm{C}, \mathrm{PB} 137512$ (LC), (Sept.).

\section{6}

Haase, G., and G. Schneider, Thermoelements from the rhenium-iridium system, U.S. At. Energy Comm. AECtr-3835.

\section{7}

Matton, G., and C. Fouré, Thermoelectric probes for measuring high temperatures in gas streams: their application to the study of flames stabilized by obstacles, 6th Symposium (International) on Combustion, New Haven, Conn., 757, Reinhold Pub. Corp.

\section{8}

Danisherskii, S. K., The immersion of thermocouples, Ind. Lab. 24, 1608 .

Ergardt, N. N., Stability of platinum-rhodium/platinum thermocouples, Trudy Vsesoyuz, Nauch.-Issledovatel. Inst. Metrol. 1958, No. 35, 87.

Gordov, A. N., and N. N. Ergardt, Some causes of errors in the measurement of temperatures by means of thermocouples, Ind. Lab. 24, 1605.

Kislyi, P. S., and G. V. Samsonov, High temperature semiconductor thermocouples, Izv, Akad. Nauk, SSSR, Otd. tekh. Nauk, Metall. Tople. 6, 135 (Nov.-Dec.).

Meyers, M. N., Irradiation study of platinum and platinum-rhodium thermocouple wire, U.S. At. Energy Comm. DC-58-5-730.

Sitnitskii, Yu. I., Dynamic characteristics of rapidly acting thermocouples, Avtomatika, Akad. Nauk Ukr. R.S.R. 1958 , No. 1,85 .

\section{9}

Altshuler, Y. A., Z. I. Bakushchik, and B. G. Klikshtein, Temperature measurement of rotating surfaces, Priborostroenie 1959, No. 5, 24.

Hartley, J. J., Thermal electromotive force of copperconstantan thermocouples as a function of junction fabrication, U.S. At. Energy Comm. SCTN-373-59(16).

Obrowski, W., Temperature measurement with thermoelements, Dechema Monograph 35, No. 528-55, 203.

Ogorodnikov, N. N., and V. Ya. Levin, Use of instruments with thermal inertia compensation for measurement of rapidly changing temperature in gases, Trudy Kubyshev. Avisto. Inst. 1959, No. 8, 65. 
Potts, J. F., and D. L. McElroy, Some results of basemetal thermocouple research at Oak Ridge National Laboratory, U.S. At. Energy Comm. TID-7856, Pt. 1.

Rudnitskii, A. A., Noble metal thermocouples for measuring high temperatures, Issledovaniya po Zhaproch. Splavam. Akad. Nauk, SSSR, Inst. Met. im. A. A. Baikova $4,380$.

Rudnitskii, A. A., Thermocouple measurement of high temperatures during steel manufacture, Fiz.-Khim. Osnovy Proizv. Stali, Akad. Nauk, SSSR, Inst. Met., Tr. 5-oi Konf. 1959, 311.

Serota, A. M., and B. K. Maltsev, A gold-platinum thermocouple, Measurement Techniques No. 8, 611 (Aug.).

Sukhov, S. A., S. Ya. Kadletz, and G. D. Pavlyuk, Investigation of electrolytic thermocouples, Measurement Techniques No. 2, 121 (Feb.).

Shiba, K., Thermoelectric thermometer of noncontacting type, Oyo Butsuri 28, 422

Tomizaroa, K., and T. Ushijama, Measurement of surface temperature by $\mathrm{Cu}-\mathrm{Co}$ (Constantan) thermocouple, Denkisik iho 23, 586 .

\section{0}

Accinno, D. J., and J. F. Schneider, Platinel- a noble metal thermocouple to replace Chromel-Alumel, Engelhard Ind., Tech. Bull. 1, 53 (Sept.).

Anderson, A. R., and D. J. Mackenzie, Materials for high (2500-4000 deg. F) gas engine temperature measurements, Aircraft Eng. 32, 201 (July).

Barrows, H., and D. J. Ryley, Temperature recovery factors in steam, Engineer 209, 903.

Bennet, H. E., The Pallador thermocouple, Platinum Metals Rev. 4, 66 (Apr.).

Berezin, G. F., A simple and highly sensitive thermocouple battery for the measurement of body surface temperature, Ind. Lab. 25, 502 (Apr.).

Blue, M. D., Thermoelectric effects in copptı-gold alloys, Phys. Rev. 117, 137.

Boudreaux, R. A., Induced thermal error for thermocouples attached to thin plates, General Electric Co. Aircraft Nucl. Propulsion Dept., Cincinnati, DC-60-545 ( May 9)

Chandler, R. L., and E. J. Dent, Temperature compensated strain gauges, Electron. Eng. 32, 414 (July).

Christy, R. W., Electric conductivity and thermoelectric power in ionic crystals, Am. J. Phys. 28, 457 (May).

Davisson, J. W., et al., Thermoelectricity, NRL Mem. Rept. 1089 (Aug.) ; PB 161977 (Dec.).

Edwin, B., Recent developments in nickel/nickel-chromium thermocouples, Elektrowärme 18, 222 (July).

Edwin, B. E., New developments in Ni/Ni-Cr thrmocouples, Eng. Dig. 21, 88 (Nov.).

Eller, H. C., and J. B. Stewart, Connect thermocouples frmly to burner tip, Elec. World 154, 45 (Sept. 5).

Haig, L. B., Thermocouple probe design method, Abstract: S.A.E. J. 68, 81 (Aug.).

Heath, J. H., High temperature thermocouples, Part I, United Kingdom At. Energy Admin. Rept. AEEW-R-141 (Dec.).

Jordan, H. C., Welded thermocouple junctions, Instr. Control Systems 33, 988 (June).

Krivka, H. A., Make your own thermocouples, Machine Design 32, 184 (June 9).

Kröckel, O., New thermocouple for high-temperature measurements, Silikat Tech. 11, 108 .

Krol, L. Ya., et al., Thermocouples from intermetallic compounds, $\mathrm{Zn} \mathrm{Sb}$ and $\mathrm{Cd} \mathrm{Sb}$, Instr. Construct. No. 8, 33 (Aug.).

Kuether, F. W., and J. C. Lachman, How reliable are the two new high-temperature thermocouples in vacuum, ISA J. 7,67 (Apr.).

Lachman, J. C., Refractory metal thermocouples, Abstract : Metal Progr. 78, 161 (Aug.).

Lacroix, R., Platinum-rhodium/platinum thermocouples, Bull. Soc. Franc. Ceram. No. 48, 19.

Levin, E. D., A thermocouple for measuring the top layer temperature of a coke mass, Ind. Lab. 25, 503 (Apr.).
Mekheev, V. S., Some sources of error in measuring temperatures with thermocouples, Ind. Lab. 26, 691.

Ongkiehong, L., and J. van Duijn, Construction of a thermocouple for measuring surface temperatures, $\mathbf{J}$. Sci. Instr. 37, 221 (June).

Parrott, J. E., The interpretation of the stationary and transient behavior of refrigerating thermocouples, Solid State Electron, 1, 135 (May).

Raezar, S. D., and H. L. Olsen, The intermittent thermometer: a new technique for the measurement of extreme temperature, Johns Hopkins Univ., Silver Spring, Md., Appl. Phys. Lab. NP-11314 (Dec.).

Rudnitskii, A. A., and I. I. Tyurin, A search for alloys suitable for high temperature thermocouples, $\mathrm{Zh}$. Neorgan. Khim. 5, 401 (Feb.)

Short, W. W., and B. H. Sage, Temperature measurements in a spherical field; transfer coefficients and corrections for thermocouples in boundary flow, A.I.Ch.E. J. 6, 163 (Mar.).

Shoults, D. R., Aircraft nuclear propulsion program brings useful byproducts, S.A.E. J. 68, 35 (Apr.).

Stevenson, J. A., The metal-clad thermocouple, Platinum Metals Rev. 4, 127 (Oct.).

Stover, C. M., Method of butt welding small thermocouples 0.001 to 0.010 inch in diameter, Rev. Sci. Instr. 31, 605 (June).

Walker, J. E. O., and R. E. Wells, Thermometry of respired air, J. Appl. Physiol. 15, 541.

West, E. D., Techniques in calorimetry: noble-metal thermocouples for differential use, Rev. Sci. Instr. 31, 896.

Yazliev, S., An investigation of the thermoelectric properties of nickel-palladium alloys, Zh. Neorgan. Khim. 5 , 2446.

Expendable immersion thermocouple, Mech. Eng. 82, 77 (Sept.).

Hi-temp thermocouples bend to fit test parts, Prod. Eng. 31,9 (Dec. 5 ).

Kanthal base metal thermocouple wire, Ind. Heating 27, 637.

Soviet thermocouple is sensitive, Chem. Eng. News 38, 44 (Aug. 1).

Thermocouple measures temperatures of molten metal, J. Franklin Inst. 269, 428.

Thermocouples for low temperature application, Electronics 33, 85 (Nov. 4).

Tungsten $\nabla s$ tungsten 74 rhenium 26 thermocouple, Englehard Ind. Tech. Bull. 1, 56 (Sept.).

Where to get the new high-temperature thermocouple materials, ISA J. 7, 66 (Apr.).

\section{1}

Arai, T. T., and J. R. Madigan, Response of a thermocouple circuit to non-steady currents, J. Appl. Phys. 32, 609 (Apr.).

Bard, J. A., Thermocouples for high temperatures, Instr. Control Systems 34, 1874 (Oct.).

Bennett, H. E., The contamination of platinum metal thermocouples, Platinum Metals Rev. 5, 132 (Oct.).

Boggs, B. C., Common parallel thermocouples for average temperature measurement, WADD TR-60-650; ASTIA AD-255 753.

Bostwick, W. E., Thermocouple loading-an exercise in impedance matching, Instr. Control Systems 34, 863 (May).

Bradley, D., and A. G. Entwistle, Determination of the emissivity, for total radiation, of small diameter platinum-10\% rhodium wires in the temperature range $600-1450^{\circ} \mathrm{C}$, Brit. J. Appl. Phys. 12, 708 (Dec.).

Brands, F. W., Two hot junctions up thermocouple output, Electronics 34, 118 (Apr. 28).

Bundy, F. P., Effect of pressure on emf of thermocouples, J. Appl. Phys. 32, 483 (Mar.).

Burnett, D. R., Transient temperature measurement errors in heated slabs for thermocouples located at the insulated surface, J. Heat Transfer 83, 505. 
Cutler, M., Thermoelectric measurements at small-area contacts, J. Appl. Phys. 32, 1075.

Darling, A. S., Thermoelectric properties of rhodiumplatinum alloys, Instr. Control Systems 34, 861 (May). de Percin, F., Some observations of the effect of direct and snow-reflected solar radiation on exposed and shielded thermocouples, Quartermaster Research and Engineering Center, Natick, Mass., Study Rept. RER-19 (Apr.) ; PB 152070 (Jan.).

Emelhanenko, O. V., and F. P. Kesamanly, Concerning a rapid method of precise measurements of thermal emf of semiconductors, Soviet Phys.: Solid State 2, 1356 (Jan.).

Franks, E., High-temperature thermocouples using nonmetallic members, Abstract: Electro-Technol. (New York) 68, 12 (July).

Glawe, G. E., R. C. Johnson, and L. N. Krause, A cooledtube pyrometer with experimental results obtained in a bigh-temperature gas stream, NASA Tech. Note D-870.

Hill, J. S., The use of Fibro platinum in thermocouple elements, Engelhard Inds. Tech. Bull. 2, 85 (Dec.).

Hsu, S. T., and F. W. Smidt, Measured variations in local surface temperatures in pool boiling of water, Trans. ASME C83, 254 (Aug.).

Johnson, W., Temperature measurement in high-temperature X-ray powder cameras, J. Sci. Instr. 38, 373.

Kelley, M. J., et al., Effect of nuclear radiation on thermocouples, Abstract: Electro-Technol. (New York) 68, 11 (July).

Kislyi, P. S., and G. V. Samsonov, High-temperature thermoelements from semiconductors, Planseeber. Pulvmet 8, 200.

Kislyi, P. S., el al., Thermoelectric characteristics of hightemperature thermocouples with electrodes made of high melting point alloys, Measurement Techniques No. 5, 366 (May).

Lachman, J. C., New developments in tungsten/tungstenrhenium thermocouples, Proc. Instr. Soc. Am. 16, Paper No. 150-LA-61.

Lachman, J. C., Thermocouples for ultrahigh temperatures, Metal Progr. 80, 73 (July).

Lachman, J. C., and J. A. McCurty, Use of refractory metals for high temperature thermocouples, Abstract: Electro-Technol. (New York) 68, 11 (July).

Lowell, H. H., H. W. Allen, and J. E. Jenkins, Electrical characteristics of four ternary platinum-rhodium-base alloys containing chromium, cobalt, or ruthenium, NASA Tech. Note D-867.

Lutz, 0. and F. von Burger-Scheidlin, Point-by-point determination of very high temperatures, Deutch. Forsch. Anst. Luft. Ber., 147.

McCarhty, D. W., Response characteristics of a radiation thermocouple at various pressures, J. Opt. Soc. Am. $51,801$.

Moffat, R. J., Gradient approach to thermocouple circuitry, Abstract: Electro-Technol. (New York) 68, 12 (July).

Nadler, M. R., and C. P. Kempter, Thermocouples for use in carbon atmospheres, Rev. Sci. Instr. 32, 43 (Jan.).

Obrowslii, W., Thermoelements, Arch. Tech. Messen, 183 (Aug.).

Potts, J. F., and D. L. McElroy, Basic studies on basemetal thermocouples, Abstract: Metal Progr. 80, 162 (Apr.).

Powell, R. L., M. D. Bunch, and L. P. Caywood, Lowtemperature thermocouple thermometry, Advan. Cryog. Eng. 6, 537.

Powell, R. L., M. D. Bunch, and R. J. Corruccini, Low temperature thermocouples-I. Gold-cobalt or constantan versus copper or "normal" silver, Cryogenies 1, 139 (Mar.).

Powell, R. L., and L. P. Caywood, Low temperature characteristics of some commercial thermocouples, Advan. Cryog. Eng. 7, 517.

Sagoschen, J., Temperature measurements with thermocouples of platinum group metals, Metall. 15, 34.

Salva, S. J., Calculate change in resistance of thermocouple wire, Power 105, 96 (Feb.).
Samsonov, G. V., P. S. Kislyi, and A. D. Panasyuk, Thermoelectric properties of thermocouples with highmelting solid electrodes, Measurement Techniques No. 10, 810 (Oct.).

Scadron, L., Ceramic-insulated thermocouples, Instr. Control Systems 34, 856 (May).

Sirs, J. A., Measurement of rapid temperature changes by thermocouples, J. Sci. Instr. 38, 489 (Dec.).

Smith, E. C., Swaged Mgo thermocouples, Instr. Control Systems 34,858 (May).

Sochor, B., Instruments and methods for measuring thermal quantities, Acta Imeko, 161.

Stover, C. M., Method of making small pointed thermocouples, Rev. Sci. Instr. 32, 366 (Mar.).

Tau, K., and M. Boudart, Recombination of atoms at the surface of thermocouple probes, Can. J. Chem. 39, 1239.

Temme, M. I., and W. H. Giedt, Dual probe for high-temperature-gas measurements, U.S. At. Energy Comm. Rept. ARL 174 (Dec. 1961); ASTIA AD-274 352.

Weiss, H., An apparatus for the measurement of temperatures, using thermocouples, in high speed rotating machines, Elektrotech. Z. 13B, 353 (June 26).

Wong, P., and P. S. Schaffer, Development of a tungsten/ molybdenum immersion thermocouple for measuring molten metal temperatures in vacuum, ASTIA AD-253 949 (Apr.)

A thermocouple for the surface of high-speed cylinders, Eng. Mater. and Design 4, 599 (Sept.).

New thermocouple up to 4200 F, Metalworking Prod. 105, 83 ( Sept. 20).

Recent advances in thermocouple technology, ElectroTechnol. (New York) 68, 11 (July).

Thermocouple alloy for 5000F, Mater. in Design Eng. 54, 13 (Sept.).

Thermocouples for high temperature, Nucl. Power 6 70 (June)

Thermocouples, base metal (except copper-constantan) ambient to $1100^{\circ} \mathrm{C}, \mathrm{Bu}$ Weps-Bu Ships Calibration Program. Standards lab. Measurement system operation NT-05 (Oct. 25) ; PB 181147.

1962

Baas, P. B. R., Effect of oxide finish on nickel alloy thermocouple wires, S.A.E. Paper 524H ; Abstract S.A.E. J. 70, 102 (Sept.).

Bansal, T. D., Copper-Advance thermocouples in the temperature range $0-100^{\circ} \mathrm{C}$, J. Sci. Ind. Res. (India) 21D, 23 (Jan.).

Beck, J. T., Thermocouple temperature disturbances in low conductivity materials, Trans. ASME 84C, 124 (May).

Benson, J. M., and R. Horne, Surface temperature of thin sheets and filaments, Instr. Control Systems 35, 115 (Oct.).

Bostwick, W. E., A note on platinum/platinum-rhodium thermocouple uncertainty, Trans. Inst. Radio Engrs. NS-9, 253 (Jan.).

Caldwell, F. R., Thermocouple materials, Natl. Bur. Std. (U.S.) Monograph 40 (Mar. 1).

Chin, J. H., Effect of uncertainties in thermocouple location on computing surface heat fluxes, ARS J. 32, 273.

Clark, R. B., Time-temperature effect on jet engine thermocouple accuracy and reliability, S.A.E. Paper 524K; Abstract: S.A.E. J. 70, 102 (Sept.).

Davenport, M. E., et al., Thermocouple attachment to a direct-current heater, Trans. ASME 84C, 124 (May).

Denison, J. W., Technique to construct fine wire thermocouples, Rev. Sci. Instr. 33, 870 (Aug.)

Dreisner, A. R., et al., High temperature W/W-25 Re thermocouples, Instr. Control Systems 35, 105 (May).

Faul, J. C., Thermocouple performance in gas streams, Instr. Control Systems 35, 104 (Dec.).

Freeze, P. D., and L. O. Olsen, Thermoelectric and mechanical stability of Platinel II thermocouples in oxidizing atmospheres, ASD-TDR-62-835 (Nov.). 
Hadfeld, D., Immersion pyrometry and open hearth furnace productivity, Platinum Metals Rev. 6, 1 (Jan.).

Hahn, P. M., Evaluation of spring-loaded thermocouple probes under transient temperatures, Mater. Res. Std. 2, 403 (May).

Hawley, S. A., J. E. Breyer, and F. Dunn, Fabrication of miniature thermocouples for uhf acoustic detectors, Rev. Sci. Instr. 33, 1118 (Oct.).

Heyne, W., Precision measurements in examining the relation between thermal e.m.f. and temperature of $\mathrm{Pt}$ $\mathrm{Rh} / \mathrm{Pt}$ thermocouples by comparison with a normal thermocouple, Feingerätetech. 11, 400 (Sept.).

Jackson, P. L., Use of a large thermocouple Junction to locate temperature disturbances, Rev. Sci. Instr. 33, 334 (Mar.).

Kislyi, P. S., Prospects of utilizing refractory compounds for high temperature thermocouples, Poroshkovaya Met., Akad. Nauk SSSR 2, No. 4, 50.

Lachman, J. C., Coaxial thermocouple viewed as improvement, Abstract: S.A.E. J.70,128 (July).

Lachman, J. C., High temperatures thermocouples using tungsten-rhenium alloy tubing, S.A.E. Paper 524D, Abstract: S.A.E. J. 70, 102 (Sept.).

Lachman, J. C., New developments in W/W-RE (tung. sten/tungsten rhenium) thermocouples, ISA Trans. 1, 340 .

Ling, F. F., and T. E. Simkins, Measurement of point-wise junction condition of temperature at the interface of two-bodies in sliding contact, ASTIA AD-283 932.

MacKenzte, D. J., and M. D. Scadron, Selection of thermocouples for high gas temperature measurement, S.A.E. Paper 524E, Abstract: S.A.E. J. 70, 102 (Sept.).

Olsen, L. O., Catalytic effects of thermocouple materials, ASD-TDR-62-304; ASTIA AD-284 880; S.A.E. Paper 524G, Abstract: S.A.E. J. 70, 94 (May).

Patzke, H., A new vacuum-thermocouple made by VEB Carl Zeiss Jena, Jena Rev. No. 1, 32.

Stewart, P. J., Study of temperature distribution with rhodium-platinum thermocouple probes, Platinum Metals Rev. 6, 126 (Oet.).

Walker, B. E., C. T. Ewing, and R. R. Miller, Thermoelectric instability of some noble metal thermocouples at high temperatures, Rev. Sci. Instr. 33, 1029 (Oct.).

Walker, B. E., C. T. Ewing, and R. R. Miller, Thermoelectric instability of some noble metal thermocouples at high temperatures, U.S. Naval Res. Lab., Washington, D.C., Rept. 5792 (June 29) ; ASTIA AD-282 154.

White, F. J., Accuracy of thermocouples in radiant-heat testing, Exp. Mech. 2, 204 (July).

Wolfe, R., and J. H. Wernick, Thermoelectric devices and materials, Bell Lab., Record 40, 190 (June).

Wormser, A. F., and R. A. Pfuntner, Thermocouple tells temperature above its melting point, S.A.E. J. 70, 56 (May).

Zenin, A. A., Errors in the readings of thermocouples passed through flames, Inzh. Fiz. Zh. 5, 68 (May).

A rhodium-platinum thermocouple for high temperature, Platinum Metals Rev. 6, 96 (July).

Gage eliminates surface heat loss, Missiles and Rockets 11, 36 (Dec. 3 ).

How and when precious metal thermocouples should be used, $\mathbf{R} \& \mathrm{D}, 45$ (Jan.).

\section{Resistance Devices}

\section{5}

Hotta, H., Substitute for platinum/platinum-rhodium thermocouples, Kinzoku 25, 459 .

\section{7}

Ciborowski, F., Influence of epitemperature of thermistors on temperature measuring, Pomiary, Automat., Kontrola 3, No. 3, 105.
Estrin, B. S., and P. B. Kantor, Temperature measure ment in the range of $300-500^{\circ} \mathrm{C}$, Measurement Tech niques No. 10, 774 .

Grashdankina, N. P., L. I. Domanskaya, and A. K. Kikrin, Measurements of temperature in high-pressure chamber: by means of thermistors, Measurement Techniques No. 10,771

Manassi, V., The measurement of temperature with electric resistance thermometers, Elletrotecnica 46, 503 (Aug. 10).

\section{0}

Ambler, E., and H. Plumb, Use of carbon resistors as low temperature thermometers in the presence of stray r.f. (radio frequency) fields, Rev. Sci. Instr. 31, 656.

Barber, C. R., Resistance thermometers for low temperatures, Progr. Cryog. 2, 147.

Belinskii, L. I., and A. I. Pilorskii, Semiconductor thermometer, Instr. Construct. No. 10, 25 (Oct.).

Christiansen, W. H., The use of fine unheated wires in shock tubes, Phys. Fluids 3, 1027.

Gniewek, J. J., and R. J. Corruccini, Oarbon resistance thermometry with mixed dc and rf currents, Rev. Sci. Instr. 31, 899.

Herr, A. C., H. G. Terbeck, and M. W. Tiefermann, Suitability of carbon resistors for field measurements of temperatures in the range of $35^{\circ}$ to $100^{\circ} \mathrm{R}, \mathrm{NASA}$ Tech. Note D-264 (Feb.).

Kostryukov, V. N., Platinum thermometer for calorimetric work, Instr. Exp. Tech. No. 6, 978 (Sept.).

Leslie, W. H. P., J. J. Hunter, and D. Robb, Precision temperature measurement outside the laboratory, Research 13, 250 ( July).

Lockett, O. J., A clinical thermometer, Lancet 1, 1391.

Lowenthal, G. C., and A. F. A. Harper, Resistance-temperature relationship of platinum at low temperatures and its influence on precision thermometry, Brit. J. Appl. Phys. 205 (May).

Norton, H. N., Resistance elements for missile temperatures, Instr. Control Systems 33, 922 (June).

Obrowski, W., Platinum resistance thermometer for high temperatures, Platinum Metals Rev. 4, 102.

Pavlova, I. A., The use of semiconductor thermometers for measuring low temperatures, Proc. Intern. Congr. Refrig., 10th, Copenhagen 1959, 1, 410.

Perelshina, A. P., The results of an experimental investigation of thermoelectromotive force in thermistors, Inzh. Fiz. Zh. 3, 119 (A pr.).

Rogers, G. B., and F. A. Raal, Semiconducting diamonds as thermistors, Rev. Sci. Instr. 31, 663 .

Rose, V. W., Resistance temperature detector, Instr. Control Systems 33, 790 (May).

Sharven, Yu. V., Anthracite coal thermometers for various temperature ranges, Instr. Exp. Tech. No. 1, 153 (Jan.).

Smith, R. W., An evaluation of thermistors: thermally sensitvie semiconductors, General Motors Eng. J. 7, 14 (Oct.).

Sterling, P. H., and H. Ho, Modern trends in resistance thermometry, Ind. Eng. Chem. 52, 59A (July).

Blue diamonds make rugged thermistors, Electronics 33, 78 ( Aug.).

Platinum resistance thermometers, ISA J. 7, 60 (Aug.).

Resistance thermometer claimed accurate to $1560^{\circ} \mathrm{F}$, Prod. Eng. 31, 9 (Aug. 29).

What do you know about platinum resistance thermometers, ISA J. 7, 60 (Aug.).

1961

Anderson, A. R., and T. M. Stickney, Ceramic resistance thermometers as temperature sensors above $2200^{\circ} \mathbf{R}$, Instr. Control Systems 34, 1864 (Oct.).

Ballard, H. N., Response time of and effects of radiation on the VECO bead thermistor, Proc. Instr. Soc. Am. 16, Paper No. 159-LA-61. 
Barber, C. R., and W. W. Blanke, A platinum resistance thermometer for use at high temperatures, J. Sci. Instr. 38, 17 (Jan.).

Bird, F. F., and W. E. Jackson, Accuracy in resistance thermometer measurements, Proc. Instr. Soc. Am. 16, Paper No. 157-LA-61.

Edlow, M. H., and H. H. Plumb, Reproducibilities of carbon and germanium thermometers at $4.2^{\circ} \mathrm{K}$, Advan. Cryog. Eng. 6, 542.

Flanagan, C. D., Continuous recording temperature measurement by resistance, Electro-Technol. (New York) 67, 158 (Apr.).

Gogin, Yu. N., A resistance thermometer made from a sparking plug, Measurement Techniques No. 5, 411 (Jan.).

Hornung, E. W. and D. N. Lyon, Characteristics of several carbon thermometer-heaters at low temperature and in magnetic flelds to 100 kilogauss, Rev. Sci. Instr. 32, 684 (June).

Kachurin, L. G., Checking the sensitivity of differential resistance thermometers in unbalanced bridge circuits, Measurement Techniques No. 7, 603 (Feb.).

Kaganov, M. A., and Yu. L. Rozenshtok, Utilization of thermistors for correcting differential temperaturedifference measuring circuits, Measurement Techniques No. 9, 712 (Sept.).

Kozhukh, V. Ya., Automatic measurement of small temperature differences, Measurement Techniques No. 11, 887 (Nov.).

Lindenfeld, P., Tests and comparison of carbon and germanium thermometers, Rev. Sci. Instr. 32, 9 (Jan.).

Low, F. J., Gallium-doped germanium resistance thermometers, Advan. Cryog. Eng 7, 514.

Low, F. J., Low temperature germanium bolometer, J. Opt Soc. Am. 51, 1300.

Martin, P. E., and H. Richards, Thermistors as cryogenic temperature sensors, Advan. Cryog. Eng. 7, 522.

Mikhailov, N. N., and A. Ya. Kaganorskii, Carbon resistance thermometers for low temperatures, Inst. Exp. Tech. No. 3, 606 (May-June) ; Cryogenics 2, 98 (Dec.). Nagao, F., S. Ohigashi, and I. Higashino, A radio-frequency resistance thermometer, Jap. Soc. Mech. Engrs. Bull. 4, 340 (May).

Nussbaum, A., Semiconductor thermometers, Control Eng. 8,145 (Sept.).

Orlov, V. Yu., Linearization of the scales of semiconductor thermistor thermometers, Instr. Exp. Tech. No. 1, 198 (Jan.).

Pallett, J. E., The transistor as a temperature-sensing device in temperature control systems, Electron. Eng. 33, 360 (June).

Ramanadham, R., A. V. S. Murty, and M. P. M. Reddy, A thermometer for the study of microthermal structure of the turbulent layer of the ocean, J. Sci. Ind. Res. (India) 200, 233 (June).

Ryner, H., Temperature measurement in a crystal-oven design, Electron. Design 9, 34 (May 10).

Schweb, O., and G. C. Temes, Thermistor-resistor temperature sensing networks, Electro-Technol. (New York) 68, 71 (Nov.).

Shaw, D., The transistor as a temperature-sensing device, Electron. Eng. 33, 528 (Aug.)

Ipatov, V. V., and I. Ya. Magin, Miniature resistance thermometers for checking the operation of bearings, Measurement Techniques No. 3, 196 (Mar.).

Tserikh, F. A., Experience gained in using semiconductor resistance thermometers for remote measurements of temperature, Measurement Techniques No. 3, 197 (Mar.).

Yates, B., and C. H. Panter, Indium resistance thermometer, J. Sci. Instr. 38, 196 (May).

Zavaritskii, N. V., and A. I. Shal'nikov, Preparation of miniature carbon resistance thermometers for low temperatures, Instr. Exp. Tech. No. 1, 195 (Jan.).
Altenburger, S., New method for the determination of temperature from the resistance of a standard platinumresistance thermometer, Feingeräte Tech. 11, 116.

Barber, C. R., and J. A. Hall, Progress in platinum resistance thermometry, Brit. J. Appl. Phys. 13, 147 (Apr.).

Barton, L. E., Measuring temperature with diodes and transistors, Electronics 35, 38 (May 4).

Blakemore, J. S., Design of germanium for thermometric applications, Rev. Sci. Instr. 33, 106 (Jan.).

Blakemore, J. S. Germanium for low-temperature resistance thermometry, Instr. Control Systems 35, 94 (May).

Blakemore, J. S., J. W. Schultz, and J. G. Meyers, Measurements on gallium-doped germanium thermometers, Rev. Sci. Instr. 33, 545.

Brown, R. F., W. M. Hubbard, and J. F. Haben, Low temperature thermometers from silicon carbide heating elements, Rev. Sci. Instr. 33, 1282 (Nov.).

Campanella, A. J., A telemetering thermometer, Marine Sci. Instr. 1, 39.

Chambers, J. T., Feasibility investigation and development of $2000^{\circ} \mathrm{C}$ resistance temperature sensor, ASTIA AD-282 358.

Gadzhiev, S. N., M. Ya. Agarunov, and K. A. Sharifor, Measurement of small temperature differences with thermistors, Zh. Fiz. Khim. 36, 897.

Glick, H. S., Thin film bolometer, Rev. Sci. Instr. 33, 1268 (Nov.).

Godin, M. C., A method of equalizing thermistors, J. Sci. Instr. 39, 241 (May).

Hehenkamp, T., Sensitive pyrometer with high relative reproductivity, Rev. Sci. Instr. 33, 229 (Mar.).

Hunter, J. J., Precision temperature measuring equipment, J. Brit. Inst. Radio Engrs. 24, 251 (Sept.).

MeNamara, A. G., Semiconductor diodes and transistors as electrical thermometers, Rev. Sci. Instr. 33, 330 (Mar.).

Mikhailov, B. I., Thermistor thermometer with a temperature compensating shunt, Instr. Construct. No. 1, 22 (Jan.).

Michaylov, V. A., L. M. Zmusko, and A. G. Lazarev, A device for measuring the temperature and sampling molten metal, ASTIA AD-265 686.

Nordon, P., and N. W. Bainbridge, The use of unmatched thermistor for the measurement of temperature difference under varying ambiant conditions, J. Sci. Instr. 39, 399 (July).

Polyakov, Yu. A.. and E. A. Mit-kina, A thin-film resistance thermometer, Instr. Exxp. Tech. No. 4, 764 (July-Aug.).

Sandborn, V. A., Application of the hot-wire, resistancetemperature transducer to the measurement of transient flows, NASA N62-12358.

Sandri, R., R. J. Brisebois, and J. K. S. Wong, On the measurement of the average temperature of a fluid stream in a tube by means of a special type of resistance thermometer, Can., Natl. Res. Council, Div. Mech. Eng., Fuel and Lubricants Lab., Mech. Eng. Rept. MI-826 (Apr.) ; ASTIA AD-283 307.

Schiemer, E. W., A portable temperature indicator, ASTIA AD-284 328 .

Vanik, M. C., and W. T. Barrett, et al., Reproducible thermistor refinement program, W. R. Grace and Co., ASTIA AD-276 659.

Diode makes accurate cryogenic thermometer, Electronics 35,28 (Nov. 9 ).

Gallium arsenide diode proves good low temperature thermometer, Machine Design 34, 26 (Nov. 22).

Silicon temperature sensors, Radio Electron. Components 3, 312 (Apr.).

\section{Radiation Devices}

1957

Popov, V. A., Photopyrometric determination of the temperature of a burning moving particle, 6th Symposium (International) on Combustion, New Haven, Conn., 751, Reinhold Pub. Corp., N.Y. 
Tyroler, J., A self-calibrating high speed photographic pyrometer, 6th Symposium (International) on Combustion, New Haven, Conn., 763, Reinhold Pub. Corp., N.Y.

\section{8}

Gordor, A. N., A. M. Brodskii, M. S. Kaiander, and A. L. Skragan, New equipment for checking heat-power instruments, Measurement Techniques No. 6, 679 (NovDec.).

Gordov, A. N., and E. A. Lapina, A technique of calculating permissible errors in industrial optical pyrometers, Measurement Techniques No. 5, 545 (Sept.-Oct.).

Kandyba, V. V., et al., Apparatus for the determination of flame temperature from the intensity of spectral lines, Trudy Komissii po Pirometrii, Vsesoyuz. Nauch. Issledovatel. Inst. Metrol., Sbornik 1958, No. 1, 69.

Merson, $\mathbf{Y}$. I., Methods and apparatus for measuring flame temperatures from their radiation in the infrared region, Trudy Komissii po Pirometril, Vsesoyuz. Nauch. Issledovatel. Inst: Metrol., Sbornik 1958, No. 1, 22.

\section{9}

Boyarskii, L. A., et al., Photoelectric method for precise optical pyrometric determination, Proces-Verbaux Séances Comite Inter-Nat. Poids Mesures Ser. 2, 26A, T151.

Burlakov, V. D., Measurement of surface temperature by the brightness-balancing method, Nekotorye Vopr. Eksperim. Fiz. 1959, No. 1, 13.

Greenshields, D. H., Spectrographic temperature measurements in a carbon-arc powered air jet, NASA Tech. Note D-169.

Katys, G. P., Dynamic properties of devices for measuring unstable temperatures, Measurement Techniques No. 3, 230 (Mar.).

Kirenkov, I. I., and E. A. Lapina, A new method for the determination of the effective wavelength of optical and photoelectric brightness pyrometers, Measurement Techniques No. 4, 288 (Apr.).

Rossler, F., Distribution of temperature of sooty fiames, Ann. Phys. 4, 396.

Vollmer, J., G. C. Rein, and J. A. Duke, Light guide radiation pyrometry, J. Opt. Soc. Am. 49, 75.

\section{0}

Ackerman, S., and J. S. Lord, Automatic brightness pyrometer uses a photomultiplier eye, ISA J. 7, 48 (Dec.).

Agnew, W. G., Two-wavelength infrared radiation method measures end-gas temperatures near their peak, $A b-$ stract: S.A.E. J. 68, 62 (Oct.).

Bell, E. E., P. B. Burnside, and F. P. Dickey, Spectral radiance of some flames and their temperature determination, J. Opt. Soc. Am. 50, 1286 (Dec.).

Boyarskii, L. A., and V. A. Kovalevskii, A laboratory objective spectropyrometer, Measurement Techniques No.1, 38.

Burrows, M. C., et al., Infrared pyrometer reads engine gas temperature to $\pm 20^{\circ}$ R, S.A.E. J. 68,76 (June).

Butivchenko, I. G., Pyrometer with an automatic signaling of the registration instant, Measurement Techniques No. 11, 957 (Nov.).

Finkelshtein, V. E., and N. G. Starunov, A spectropyrometer for temperature measurements with respect to monochromatic infrared radiation, Instr. Exp. Tech. No. 3,480 (Dec.).

Finkelshtein, V. E., N. G. Starunov, A standard infrared spectropyrometer, Measurement Techniques No. 1, 35.

Hanel, R. A., The dielectric bolometer, a new type of thermal radiation detector, NASA Tech. Note D-500.

Kirenkov, I. I., Metrological features of color pyrometry, Measurement Techniques No. 1, 33 (Mar.).

Larenz, R. W., Concerning a method for the measurement of very high temperatures in nearly transparent arc columns, NASA Tech. Transl. F-54.
Lieneweg, F., and A. Schaller, New technical radiation pyrometer, with special consideration of its optical construction, Appl. Sci. Res. Section B, 241.

Lieneweg, F., and A. Schaller, Recent industrial radiation pyrometers, with special reference to their optical construction, Arch. Tech. Messen, 241 (Nov.); 267 (Dec.).

Lovejoy, D. R., Absorbing filters and high-temperature optical pyrometry, J. Opt. Soc. Am. 50, 698.

Ludwig, H. C., The measurement of temperature in welding ares. Trans. Am. Inst. Elec. Engrs. 79, 191 (July) ; Elec. Eng. 79, 565.

McDonald, R. K., Gas temperature by infrared, Instr. Control Systems 33, 1926.

McDonald, R. K., Infrared radiometry, Instr. Control Systems 33, 1527 (Sept.).

Overbye, V. D., et al., Surface temperature variations measured in an operating engine, S.A.E. J. 68, 132 (Oct.).

Parkinson, W. H., and R. W. Nicholls, Spectroscopic temperature measurements in a shock tube using $\mathrm{CN}$ as a thermometric molecule, Can. J. Phys. 38, 715.

Pepperhoff, W., Optical pyrometry in polarized light, $\mathbf{Z}$. Angew. Phys. 12, 168.

Rossler, F., Temperature measurement of a luminous flame, Opt. Acta 7, 20 (Jan.).

Spath, H., and H. Krempl, Temperature measurements in spark discharges made with time resolved spectroscopy, Z. Angew. Phys. 12, 8.

Russell, D. C., and F. H. Schofield, A theory of the fila. ment temperature distribution of the tungsten vacuumlamp, with special reference to optical pyrometry, Phil. Trans. Roy. Soc. (London) A252, 463 (May).

Svet, D. Ya., An automatic photoelectric color pyrometer TsEP-3, Measurement Techniques No. 6, 494 (June).

Svet, D. Ya., New methods for determining the emissivity and reflectivity coefficients and the actual temperature of a self-radiating surface, Soviet Phys.-Doklady 4, 1375 (Maj-June).

Svet, D. Ya., Radiation pyrometry of metals in the near infrared, Dokl. Akad. Nauk SSSR 130, 61.

Svet, D. Ya., and A. A. Poskachei, some infra-red spectrum pyrometry systems, Instr. Construct. No. 7, 30 (July).

Viasov, M. P., Errors in measuring the temperature of turbulent fiames by optical methods, Measurement Techniques No. 11, 50 (Nov.).

Design, construction, and test of an absorption-emission pyrometer, PB 152013 (Dec.).

Measuring temperature: radiation pyrometer, Engineer 210,810 .

Two color pyrometer tells correct temperature, Steel 146, 144 (Apr. 4).

\section{1}

Agnew, W. G., End gas temperature measurement by a two-wavelength infrared radiation method, S.A.E. Trans. 69, 495 .

Bekef, G., and S. C. Brown, Microwave measurements of the radiation temperature of plasmas, J. Appl. Phys. 32,25 (Jan.).

Berman, H. L., The infrared radiometric method and its application to remote temperature measurement, Trans. Inst. Radio Engrs. IE-8, 18 (Aug.).

Burrows, M. C., S. Shimigu, P. S. Myers, and O. A. Uyehara, The measurement of unburned gas temperatures in an engine by an infrared radiation pyrometer, S. A. E. Trans. 69,514 .

Chao, B. T., et al., Experimental investigation of temperature distribution at tool-flank surface; using infrared radiation detector, Trans. Am. Soc. Mech. Engrs. B83, 496 (Nov.).

Clouston, J. G., A. G. Gaydon, I. I. Glass, and I. R. Hurle, Temperature measurements of shock waves by spectrum-line reversal method, Proc. Roy. Soc. (London) A248, 429 (1958); A252, 143 (1959); A262, 38 1961). 
Edwards, D. K., and K. E. Nelson, Maximum error in total emissivity measurements due to non-grayness of samples, ARS J. 31, 1021, (July).

Elder, S. A. Designing phototransistor pyrometers with and without feedback, Electronics 34, 56 (Dec.).

Euler, J., Precision in optical pyrometry, Chem.-Ing.Tech. 33, 448.

Felder, S. A., Designing phototransistor pyrometers, electronics 34, 56 (Dec. 8).

Freeman, L. H., A precision photon counting pyrometer, Los Alamos Sci. Lab., New Mexico, TID-12631.

Gicquel, M., and L. Nadaud, Optical measurement of gas temperatures up to $10,000^{\circ} \mathbf{K}$, Rech. Aeron. No. 84,31 (Sept.-Oct.).

King, A. $\mathbf{R}$, Compensating radiometer, Brit. J. Appl. Phys. 12, 633 .

Kolb, A. C., Measurement of plasma temperatures in the $10,000,000^{\circ} \mathrm{K}$ range, Office of Naval Research, Washington, D.C., ONR-9, 323.

Kostina, E. N., Temperature compensation in a radiation pyrometer for measuring "low" temperatures, Instr. Construct. No. 6, 3 (June).

Lalos, G. T., and M. Wolk, Feasibility study of the spectroscopic determination and temperature of an adiabatically compressed gas, NAVORD Rept. 6727; ASTIA $\mathrm{AD}-232696$; PB 154720 .

Middlehurst, J., and T. P. Jones, Photoelectric optical pyrometer, J. Sci. Instr. 38, 202.

Millikan, R. C., Measurement of particle and gas temperatures in a slightly luminous pre-mixed flame, J. Opt. Soc. Am. 51, 535.

Müller, H., Temperature measurement by measuring radiation, Arch. Tech. Messen, 99 (May).

Nagler, R. G., Application of spectroscopic temperature measuring method to definition of a plasma arc flame, Jet Propulsion Lab. Calif. Inst. Tech. Rept. No. 32-66; ASTIA AD-251 105.

Neuroth, N., Rapid indicating radiation pyrometer for temperature measurement between 300 and $900^{\circ} \mathrm{C}$, Glastech. Ber. 34, 197 (Mar.).

Penner, S. S., Spectroscopic methods of temperature measurements, Calif. Inst. Tech., Pasadena, Guggenheim Jet Propulsion Center, Tech. Rept. AFOSR-286 (Mar.).

Poland, D. E., J. W. Green, and J. L. Margrave, Corrected optical pyrometer readings, Natl. Bur. Std. (U.S.) Monograph 30 (Apr.).

Reynolds, P. M., Emissivity errors of infra-red pyrometers in relation to spectral response, Brit. J. Appl. Phys. 12, 401 (Aug.).

Shiba, K., and K. Doi, Polarization optical pyrometer, Oyo Butsuri 30, 17.

Stall, A. M., The measurement of bioclimatological heat exchange, ASTIA AD-259 074.

Sterling, P. H., and H. Ho, Radiative pyrometry, Ind. Eng. Chem. 53, 53A (Aug.).

Takenaka, Y., Study on radiation pyrometer, J. Japan Soc. Aero. and Space Sci. 9, 1 (Mar.).

Tingwaldt, C., and U. Schley, An optical method for the direct determination of the true temperature of glowing metal, Z. Instrumentenk. 69, 205 (July).

Tsuchiya, S., Temperature measurement by modified $\mathrm{Na}$ D line reversal method, Aeron. Res. Inst. Tokyo Univ. Rept. 366 (June).

Van Laethem, R., et al., Temperature measurement of glass by radiation analysis, Am. Ceram. Soc. J. 44, 321.

Walesch, W., and F. Becker, Continuous temperature control with an optically-regulated control thermometer, Z. Physik. Chem. (Frankfurt) 29, 371.

Wilson, J. H., Temperature measurement with disappearing-filament pyrometer, $\mathrm{R} \& \mathrm{D}$ No. 3, 58 (Nov.).

Wurster, W., Spectroscopic measurement of the temperature of shock-heated oxygen, Planetary \& Space Sci. 3, 158 (Feb.).

High-speed three-color pyrometer, Natl. Bur. Std. (U.S.) Tech. News Bull. 45, 148 (Sept.); Instr. Control Systems 34, 1873 (Oct.).
Photoelectric pyrometer developed, Natl. Bur. Std. (U.S.) Tech. News Bull. 45, 165 (Oct.).

Solar cells improve pyrometer precision, Engineering 182, 362.

Symposium on optical spectrometric measurement of high temperatures, Univ. of Chicago, 1960. Optical spectrometric measurements of high temperatures, Univ. of Chicago Press, Chicago.

\section{2}

Allen, R. D., Total emissivity and spectral emissivity at $0.65 \mu$ of porous tungsten and tungsten bearing alloys above $1600^{\circ} \mathrm{K}$, ARS J. 32, 965.

Cooper, J., A fast total responise total-radiation detector, Nature (London) 194, 269 (Apr. 21).

Cooper, J., Minimum detectable power of a pyroelectric thermal receiver, Rev. Sci. Instr. 33, 92 (Jan.).

Crabol, J., Solutions to some problems of wall temperature determination, O.N.E.R.A. TR 108 (Nov.).

Donahue, R. J., and R. F. Majkowski, Spectroscopic measurements of temperatures and densities in a cesium plasma, J. Appl. Phys. 33, 3 (Jan.).

Fuhs, A. E., Spectral radiance and emissivity of plasma and temperature determination, ASTIA AD-273 590.

Funk, J. P., Ribbon thermopile, J. Sci. Instr. 39, 32 (Jan.).

Grandin, M., G. Maillot, and P. Rodicq, T'wo-color pyrometer, Mesur. Control Ind. 27, 633 (May).

Hecht, G. J., A near infrared two wavelength pyrometer, Autom. Control 16, 51 (Mar.).

Hottel, H. C., G. C. Williams, P. H. Dundas, and W. P. Jensen, Optical methods of measuring plasma jet temperatures, WADD TR 60-676 (June 1961 and Feb. 1962) ; ASTIA AD-266 723.

Hukuo, N., et al., Measurement of brightness temperature by a photomultiplier, Rept. Gov. Ind. Res. Inst., Nagoya 11, 70 (Feb.).

Kadyshevich, A. E., The present state and lines of development of optical flame pyrometry, Soviet Phys.-Uspekhi 5, 346 (Oct.).

Knopp, C. F., C. F. Gottschlich, and A. B. Cambel, A spectroscopic technique for the measurement of temperature in transparent plasmas, AFOSR-1100; ASTIA AD-277 352.

Kostkowski, H. J., and R. D. Lee, Theory and methods of optical pyrometry, Natl. Bur. Std. (U.S.) Monograph 41 (Mar. 1).

Lader, S., Spectrographic investigation of temperatures in a plasma jet arc tunnel, Picatinny Arsenal Tech. Mem. 1001 (Apr.).

Lapworth, K. C., J. E. G. Townsend, and K. Bridgeman, Reservoir temperature measurements in a hypersonic shock tunnel by sodium line reversal. Part I. Single beam method, Aeron. Res. Council (Gt. Brit.) Rept. No. 23341 (Dec. 1961) ; ASTIA AD-274 711 (July).

Lee, R. D., A new photoelectric pyrometer, Mesur. Control Ind. 27, 647 (May).

Moffit, G., Study of a temperature measuring system for the $1000^{\circ} \mathrm{O}$ to $2500^{\circ} \mathrm{C}$ range, U.S.A.F., Systems Com. mand, Aero Systems Div., Flight Control Lab. ASD TR-61-487 (Feb.) ; ASTIA AD-274 794.

Penzias, G. J., S. A. Dolin, and R. H. Tourin, Infrared rays find rocket gas temperature, Abstract: S.A.E. J. 70,99 (July).

Peperone, S. J., X-band measurement of shock-tube plasma temperature, J. Appl. Phys. 33, 767 (Feb.).

Schumacher, B. W., W. Wojcik, and R. C. Zavitz, Monitoring system for an oxygen steel furnace using a betaray gauge in the flame, Intern. J. Appl. Radiation Isotopes 13, 123 (Mar.).

Spinrad, H., Spectroscopic temperature and pressure measurements in the Venus atmosphere, Jet Propulsion Lab., Calif. Inst. Tech. JPI-TR-32-251 (June).

Svet, D. Ya., Radiation pyrometry in the blue-violet and ultraviolet regions of the spectrum. Soviet Phys.Doklady 6,907 (Apr.). 
Themelis, N. J., and W. H. Gauvin, Two-wavelength pyrometer for temperature measurements in gas-solid systems, Can. J. Chem. Eng. 40, 157 (Aug.).

Tourin, R. H., Infrared techniques for temperature measurement in plasmajets, Trans. Am. Soc. Mech. Engrs. 84C, 164 (May).

Tourin, R. H., P. M. Henry, E. T. Liang, M. L. Hecht and S. Dolin, Measurement of temperatures in ionized gases by means of infrared radiation, Wright-Patterson AFB, Aeron. Res. Lab., ARL 62-314 (Mar.) ; ASTIA $\mathrm{AD}-278045$.

Vali, W., and R. S. De Voto, A two-color pyrometer for the measurement of temperature and contamination level in a spark-heated hypervelocity wind tunnel, Arnold Eng. Develop. Center TDR-62-174 (Aug.).

Watson, R., Spectroscopic temperature measurements on the $\mathrm{OH}^{2} \Sigma \rightarrow 2 \pi$ band system for a transparent gas in a shock tube, Guggenheim Jet Propulsion Center, Calif. Inst. Tech., Pasadena, Tech. Rept. No. 29 (June).

Photoelectric pyrometer, Instr. Control Systems 35, 178 (July).

Photoelectric pyrometer, Instr. Pract. 16, 77 (Jan.).

\section{Expansion Devices}

1959

Yaryshev, N. A., Inertia response curves for liquid-inglass thermometers, Nauch. Trudy Leningrad, Inst. Tochnoi Mekh. i Optiki 1959, No. 37, 91-8.

1960

Durieux, M., and H. van Dijk, The use of vapor-pressure thermometer in the liquid $\mathrm{He}^{\mathrm{s}}$ region, Proc. Intern. Congr. Refrig., 10th, Copenhagen, 1959, 1, 197.

\section{1}

Hall, J. A., and V. M. Leaver, Stabilization of thermometers of borosilicate glass for use at high temperatures, J. Sci. Instr. 38, 178 (May)

Kebbon, E. R., Bimetal thermometers, Instr. Control Systems 34, 841 (May).

Nelson, R. C., Temperature measurement by filled system, Instr. Control Systems 34, 849 (May).

Oishi, J., High temperature determination by a new gas thermometer with constant bulb temperature. I. Measuring methods, J. Phys. Soc. Japan 16, 2056.

Swindells, J. F., Liquid-in-glass thermometers, Instr. Control Systems 34, 846 (May).

Sychev, I. A., Temperature error of liquid manometric thermometers and methods for compensation, Measurement Techniques No. 10, 803 (Oct.).

Filled-system thermometers, Instr. Control Systems 34, 1250 ( July)

\section{2}

Bendt, P. J., Liquid level He thermometer, Rev. Sci. Instr. 33, 759 .

Gruzsniczki, F., Very precise calibration of glass thermometers, Metrol. Apl. (Bucharest) 9, No. 2, 49.

Schnabel, O., and H. Löber, Physical procedure in the construction of clinical thermometers, Glastech. Ber. 35, 131 (Mar.).

\section{Aspirated Devices}

\section{0}

Goltsov, I. P., Pneumatic thermometer, Priborostroenie 1960, No. 5, 13 .

Hochreiter, H. M., Status report on the pneumatic temperature measuring system studies for the EGCR, Oak Ridge Natl. Lab., Tenn., CF-60-12-114 (Dec. 30).
Edmonson, R. B., W. R. Thompson, and A. L. Hines, Theory of a pneumatic dilution calorimetric probe, ARS J. 32, 257.

Welshimer, D. E., The experimental application of sonicpneumatic probe systems to temperature measurement in a hypersonic air stream, U.S. Air Force, Aeron. Res. Lab. ARL-62-364.

Zalmonzon, L. A., High-response measurement of the temperature of gasses and liquids by means of the simplest pneumatic and hydraulic sensing devices, Intern. Chem. Eng. 2, 169 (Apr.).

\section{Other Methods, Descriptive Articles}

\section{8}

Chukaev, K. A., A thermodynamic method of determining mean temperature of flowing gas, Measurement Techniques No. 5, 541 (Sept.-Oct.).

\section{0}

Dean, C., Using nuclear resonance to sense temperature, Electronics 33, 52 (July).

Fasoli, U., F. S. Gaeta, F. Scaramuzzi, and J. O. Thomson, Possibility of an ionic thermometer in the He II temperature range, Proc. Intern. Congr. Refrig., 10th, Copenhagen, 1959, 1, 192.

John, R. S., Field tests of a sonic anemometer-thermometer, Bull. Am. Meteorol. Soc. 41, 618 .

Leask, M. J. M., and W. P. Wolf, Magnetic method of temperature measurement between $4^{\circ}$ and $14^{\circ} \mathrm{K}$, Proc. Intern. Congr. Refrig., 10th, Copenhagen, 1959, 1, 179.

McFee, J. H., P. M. Marcus, and I. Estermann, Possible application of molecular beam techniques to the measurement of surface temperature, Rev. Sci. Instr. 31, 1013.

Meyer, R. F., A heat flux meter for use with thin film surface thermometers, Natl. Res. Council (Can.), Natl. Aeron. Estab., NRC LR-279 (Apr.).

Pokhil, P. F., V. M. Maltsev, and L. N. Galperin, Apparatus for the determination of temperature from the flame height of burning gun powder, Zh. Fiz. Khim. 34, 1131.

Scott, D. S., Flowmeters for the measurement of gas temperatures, Chem. Eng. Sci. 12, 127.

Siviter, Jr., J. H., and H. K. Strass, An investigation of a photographic technique of measuring high surface temperatures, NASA Tech. Note D-617.

High temperatures inferred from properties of heated gas-stream, Control 4, 120 (Feb.).

\section{1}

Baskin, Y., and D. C. Schell, Rocket nozzles as temperature indicators, ARS J. 31, 1275.

Brodskii, A. D., Electroacoustic gas thermometer for the low temperature range, Measurement Techniques No. 6, 453 (Dec.)

Byler, W. H., and F. R. Hayes, Fluorescence thermography, Non-destructive Testing 19, 177 (May).

Clark, F. L., and C. B. Johnson, Determination of real-gas stagnation temperature based on mass-flow consideration J. Aerospace Sci. 28, 742 (Sept.).

Hoge, H. J., Temperature measurement based on the viscous flow of gas in a Wheatstone-bridge network, Rev. Sci. Instr. 32, 1 (Jan.).

Louisnard, N., The measurement of surface temperatures by infrared cinemaphotography, Rech. Aeron. No. 80, 29 (Jan.-Feb.)

Miller, J., Temperature-indicating paints and melts, Eng. Mater. and Design 4, 728 (Nov.).

Schultz-Grunow, F., and G. Wortberg, Interferometric measurements in a flat flame, Intern. J. Heat Mass Transfer 2, 56 .

Taylor, R. D., A low temperature thermometer utilizing the Mossbauer effect, Los Alamos Sci. Labs., New Mexico, TID 12627. 
Apfel, J. H., Acoustic thermometry; measuring temperatures by means of the velocity of sound in a gas, Rev. Sci. Instr. 33, 428 (Apr.).

Best, G. T., and T. N. L. Patterson, Temperature determination from a cloud of alkali vapour in the upper atmosphere, Queen's Univ. Belfast (Gt. Britain), AFCRI-62-1049.

Cataland, G., and H. H. Plumb, Acoustical interferometer employed as an instrument for measuring low absolute temperature, J. Acoust. Soc. Am. 34, 1145 (Aug.).

Danberg, J. E., The equilibrium temperature probe, a device for measuring temperatures in hypersonic boundary layers, Naval Ordnance Lab., White Oak, Md., Aeroballistic Research Rept. 146, NOL TR-61-2 (Feb.).

Fletcher, K. A., Precise temperature measurement and control using a.c. bridge techniques, SIMA Rev. 2, 93 (July).

Fournet, M., Kinetic measurement of temperatures, J. Phys. Radium 23, Suppl. No. 3, 25A.

Gorini, I., and S. Sartori, Quartz thermometer, Rev. Sci. Instr. 33, 883 (Aug.).

Grey, J., and P. F. Jacobs, A calorimetric probe for the measurement of high gas temperature, Guggenheim Labs. for the Aerospace Propulsion Sciences, Princeton, N.J., Aeron. Eng. Lab. Rept. 602 (Apr.) ; AD-275 359.

Grey, J., P. F. Jacobs, and M. P. Sherman, Calorimetric probe for the measurement of extremely high temperatures, Rev. Sci. Instr. 33, 738 ( July).

Higgins, L. L., Measurement of temperature, salinity and velocity of water through electrolytic conductivity measurements, ASTIA AD-276 746.

Hisam, E., and W. Bez, Development of a diagnostic device for the determination of mean effective temperatures in plasmas using shock wave measurements, PB 153626 (LC) ; ASTIA AD-235 859.

Long, V. D., Estimation of the mean radiating temperature of a cylinder of combustion gas, J. Inst. Fuel 35, 431 (Oct.).

Schumacher, B. W., W. Wojik, and R. C. Zavitz, Monitoring system of an oxygen steel furnace using a $\beta$-ray gage in the flame, Intern. J. Appl. Radiation Isotopes 13, 123.

Wade, W. H., and L. J. Slutsky, Quartz crystal thermometer, Rev. Sci. Instr. 33, 212 (Feb.).

Walsh, D., The measurement of temperature in an argon shock tube by microwave noise radiation, Aeron. Res. Council (Gt. Brit.) ARC 22930 (June 13).

Low temperature ultrasonic thermometer, Engineering 194, 730 (Nov. 30).

Temperature measurement by change in hardness in metals, Motortech. Z. 23, 49.

\section{Special Applications, Method Not Specified in Title}

1957

Moutet, A., Instantaneous flame-temperature measurements, France, O.N.E.R.A. Tech. Rept. No. 88.

\section{0}

Affleck, J. H., Measuring cathode temperatures, Electronics 33, 80 (Apr. 15).

Becker, F. S., and F. M. Kepler, How to measure tubewall temperature, Oil Gas J. 58, 101 (July 18).

Culpin, M. F., and K. A. Martin, Instruments for measuring the temperature of a running thread-line and of a jet of viscous liquids, J. Sci. Instr. 37, 250 (July).

Daunt, J. G., Thermometers for the temperature range $0.1^{\circ} \mathrm{K}$ to $20^{\circ} \mathrm{K}$, Ohio State Univ. Res. Found. Rept. 712 (Dec.) ; PB 149504.

Dyakonov, I. I., Certain problems in measuring the temperature of rotating objects, Measurement Techniques No. 1, 44 (Nov.).
Eckert, E. R. G., R. Eichhorn, and T. L. Eddy, Measurement of temperature profiles in laminar and turbulent axisymmetric boundary layers on a cylinder with nonuniform wall temperature, USAF, Aeron. Res. Lab., Wright-Patterson AFB, ARL TN 60-61 (Dec.).

Hame, T. G., W. H. Peake, et al., Preliminary analysis of methods for temperature determination at altitudes above 120,000, Ohio State Univ. Res. Found. Rept. 973-2 (May) ; PB 152669 (LC) ; ASTIA AD-242 206.

Joseph A. J. V., Fuel nozzle temperature measurement, Engineering 190, 762.

Joseph, A. J. V., Temperature measurement of fuel injection nozzles, Hawker Siddeley Tech. J. 2, 2 (Aug.).

Losev, S. A., and N. A. Generalov, Measuring the temperature of a gas downstream from a shock wave, Instr. Exp. Tech. No. 3, 454 (Apr.).

Ryley, D. J., An indirect method of measuring static temperature in supersaturated expanding steam, Engineer $210,343$.

Stewart, L. E., New Ways to measure temperature; $1000 \mathrm{~F}$ and above, Power 104, 218 (May).

Sturgeon, G. M., New wire temperature meter, Wire and Wire Prod. 35, 721 (June).

Sturgeon, G. M., Wire temperature measurement, Wire Inds. 27, 261 (Mar.).

Svinoruk, V. I., and L. F. Lependin, Temperature measurement at a point on the surface of an electrically conductive sample, Ind. Lab. 26, 785.

Thun, R. E., Rugged film resistor thermometer for the measurement of surface temperature, Rev. Sci. Instr. 31, 446 (Apr.).

Wood, R. D., Heated hypersonic stagnation-temperature probe, J. Aerospace Sci. 27, 556 (July).

Flame temperature determination, Instr. Control Systems 33, 821 (May).

Precision thermometry at low temperature, Electronics 33, 98 (June).

Thermometer for $600 \mathrm{deg}$. C plus. Space/Aeronautics 33, 242 (May).

Thermometry for low temperature, Instr. Control Systems $33,1917$.

Wire temperature meter, Metallurgia 62, 64 (Aug.).

\section{1}

Beattie, J. R., The measurement of the temperature of transparent materials, Acta Imeko, 210.

Blackshear, P. L., Probe senses fast temperature changes, Chem. Eng. News 39, 39 (Aug. 28).

Blackshear, P. L., and L. M. Fingerson, Some new measuring techniques in high temperature measurements, James Forrestal Res. Center, Princeton Univ., N.J., Tech. Rept. MIN-3-P (Dec.); ASTIA AD-270 364.

Brodskii, A. D., and A. V. Savataev, A new method of absolute temperature measurement, Measurement Techniques No. 5, 397 (Jan.).

Brown, E. A., et al., Steady-state heat flux gauge, Rev. Sci. Instr. 32, 984 (Aug.).

Daunt, J. G., and D. O. Edwards, Measurement of temperature below 1 degree K, ASTIA AD-255 582.

De Leo, R. V., F. D. Werner, and F. W. Hagen, Measurement of mean temperature in a duct, Instr. Control Systems 34, 1659 (Sept.).

Elliott, R. D., Dynamic behavior of missile skin temperature transducers, Proc. Instr. Soc. Am. 16, Paper No. $160-\mathrm{LA}-61$.

Gordov, A. N., et al., Complex of metrological work on establishing methods and apparatus for precise measurements of high temperature, Measurement Techniques No. 1, 31 (Jan.).

Kazachkov, R. V., Measurements of the piston temperature of high-speed internal combustion engines, Measurement Techniques No. 5, 402 (Jan.).

Lemke, B., Determination of final temperature in a gun tunnel, J. Aerospace Sci. 28, 827 (Oct.).

Moore, F. D., and R. B. Mesler, Measurement of rapid surface temperature fluctuations during nucleate boiling of water, A.I.Ch.E. J. 7, 620 (Dec.). 
Netter, P., G. Seyffarth, and H. John, Design and function of a submerged temperature measuring device in an open hearth steelworks, Neue Hütte 6,475 (Aug.).

Ney, E. P., R. W. Maas, and W. F. Huch, The measurement of atmospheric temperature, J. Meteorol. 18, 60 (Feb.).

Overbeck, C. J., Apparatus review; demonstration thermometer, Am. J. Phys. 29, 368 (June).

Rae, D., A measurement of the temperature of some frictional sparks, Combust. Flame 5,341 .

Reimer, L., and R. Christenhuss, a reversible temperature indicator in the form of an evaporated layer for estimating the temperature of an object in the electron microscope, Naturwissenschaften 48,619 .

Schoolman, S. A., and D. A. McBlain, The measurement of temperature changes in an adiabatic expansion, Proc. Iowa Acad. Sci. 68, 439.

Stewart, L. E., Measure gas temperature by multipoint traversing, Power 105, 180 (Feb.).

Walker, R. E., and S. E. Grenleski, Instrument for measuring total incident radiant heat transfer to a jet engine surface, ARS J. 31, 77 (Jan.).

Werner, F. D., R. V. De Leo, and B. Rogal, Total temperature probes, Flight 80, 737.

Measurement of engine temperature, Engineer 211, 386.

Pyrometer for moving surfaces, Control 4, 120 (Feb.).

Temperature measurement of moving engine components Shell Aviation News No. 281, 8.

\section{2}

Baldwin, A. L., Dynamic temperature coefficient measurements, Instr. Control Systems 35, 97 (May).

Cooper, J., A fast-response pyroelectric thermal detector, J. Sci. Instr. 39, 467 (Sept.).

Ebel, H., A method of measuring rapidly changing temperatures, Naturwissenschaften 49,80 .

Eschenbach, R. C., Water temperature measurement, Am. J. Phys. 30, 604 (Aug.).

Fletcher, K. A., Industrial temperature measurement, Ind. Electron. 1, 66 (Nov.) .

Hadfleld, D., Periodic pyrometer checks accelerate steel process, Steel 150, 92 (Feb.).

Land, T., Advances in glass temperature measurement, Glass Ind. 43, 244 (May).

Magnus, A. B., Calculating temperatures in hydraulic systems, Hydraulics and Pneumatics 15, 69 (Nov.).

Manson, D. J., Temperature measurements in oxy-hydrogen flames using scattered neutrons and conventional methods, ASTIA AD-277 747.

Muntz, E. P., Static temperature measurements in a flowing gas, Phys. Fluids 5, 80.

Rosenberg, N. W., W. H. Hamilton, and D. J. Lovell, Rocket exhaust radiation.measurements in the upper atmosphere, Appl. Optics 1, 115 (Mar.).

Swain, R. R., Pyrometer monitors molten metal temperatures, Steel 150, 78 (June 4).

Vidal, R. J., Transient surface temperature measurements, Cornell Aeron. Lab. Rept. 114 (Mar.); ASTIA AD-275 818.

Woodley, J. G., and J. F. W. Crane, A boundary layer probe for the direct measurement of aerodynamic heating, Royal Aircraft Establ. (Gt. Brit.), Tech. Note No. Aero 2808 (Jan.) ; ASTIA AD-274 842 (July).

Maximum temperature indicators, $R$ \& $\mathbf{D}, 48$ (Jan.).

Measuring traction motor commutator temperature, Engineer 214, 30 (July 6 ).

Miniature thermometer fc: moving parts, Engineering 194,800 .

Probe for measurements in high-temperature fluids, Control 5,96 (July).

Surface pyrometer for high-speed cylinders, Engineer 214, 960 (Nov. 30).

Temperature measurement of metallic surfaces, Eng. Mater. and Design 5, 116 (Feb.).

\section{Nuclear Applications of}

\section{Measurement}

Temperature

1960

Clark, R. G., Clamp-on resistance temperature detectors for reactor use, Metal Progr. 78, 156 (Aug.).

Gilbert, R. L. G., Analogue-digital converter with long life, equipment designed for temperature measurement in nuclear power stations, J. Brit. Inst. Radio Engrs. 20,529 (July).

Guskov, Yu. K., and A. V. Zvonarev, Thermocouple system for measurement of large neutron fluxes, Instr. Exp. Tech. No. 5, 821 (June).

Harmon, T. P., An electroplated neutron thermopile for the 3-Mw GTR, NARF-59-20T; MR-N-226; PB 150016 (LC).

Kosut, B. S., Specifications for thermocouples, stainless steel sheathed, corrosion resistant for nuclear service, General Electric Co., Hanford At. Prod. Operation, Richland, Wash., HW-64744 (Apr.).

Lovett, D. B., Use of isolated junction sheathed thermocouples for moderator temperature measurements, General Electric Co., Hanford At. Prod. Operation, Richland, Wash., HW-65738 (June 16).

\section{1}

Clough, D. J., Temperature control and measurement in sodium-filled irradiation capsules, AERE R-3689 (Apr.).

Ross, C. W., Effect of thermal neutron irradiation on thermocouples and resistance thermometers, Trans. Inst. Radio Engrs. NS-8, 110 (Oct.).

Shenault, L. H., and T. F. MeGrath, Reactor core tempera ture measurement, ARS J. 31, 799 (June).

Development of high temperature sensors, U.S. At. Energy Comm. PWAC-339 (June 30).

Driesner, A. R., L. P. Kempter, C. P. Landahl, C. A. Linder, and T. E. Springer, High temperature thermocouples in the Rover Program, Trans. Inst. Radio Engrs. NS-9, 247 (Jan.).

McCann, J. A., Temperature measurement theory, At. Energy Comm. Rept. KAPL 2067-2 (Apr. 1).

Ross, C. W., Effect of thermal neutron irradiation on thermocouples and resistance thermometers, Commun. Electron., 192 (July).

\section{Associated Equipment and Testing Procedure}

\section{1}

Tarr, P. R., Methods for connection to revolving thermocouples, NACA Res. Mem. E50J23a (Jan. 18).

\section{8}

Lalos, G. T., R. J. Corruccini, and H. P. Broida, Design and construction of a black body and its use in the calibration of a grating spectroradiometer, Rev. Sci. Instr. 29, 505.

Levin, G. M., and V. I. Volmir, Characteristic thermal inertia curves of conventional thermocouples and resistance thermometers, Measurement Techniques No. 6, 686 (Nop-Dec.).

Nikiforov, V. D., Testing thermocouples and pyrometric instruments, Measurement Techniques No. 5, 548 (Sept.Oct.).

\section{9}

Arefev, A. A., Three-channel amplifier equipment for thermocouples, Measurement Techniques No. 2, 120 (Feb.).

\section{0}

Almond, R. J., Errors in thermocouple circuits, Instr. Control Systems 33, 80 (Jan.).

Ashekhmin, V. I., and E. V. Kovalskii, A slide rule for thermocouples, Measurement Techniques No. 2, 115 (Nov.). 
Briscoe, W. L., Improved bridge for low temperature measurements, Rev. Sci. Instr. 31, 999 (Sept.).

Dauphinee, I. T. M., and H. Preston-Thomas, Direct reading resistance thermometer bridge, Rev. Sci. Instr. 31, 253.

Eisner, R. L., Apparatus for accurate measurement of thermoelectric power, Rev. Sci. Instr. 31, 462 (Apr.).

Foltz, H. L., and W. R. Brown, Self-sealing thermocouple gland, Machine Design 32, 176 (May 12).

Harman, G. G., Hard gallium alloys for use as low contact resistance electrodes and for bonding thermocouples into samples, Rev. Sci. Instr. 31, 717 (July).

Holden, T. S., Multipoint digital temperature recorder with punched tape output, J. Sci. Instr. 37, 269 (Aug.).

Kane, M. V., Thermocouple current indicators, Instr. Control Systems 33, 608 (Apr.).

Kurtzrock, R. C., Quick connector for multipoint thermocouple assemblies, Rev. Sci. Instr. 31, 457 (Apr.).

Levin, G. M., and V. I. Volmir, Methods for testing thermal inertia in thermocouples and resistance thermometers, Measurement Techniques No. 4, 309.

Moeller, C. E., Do shields improve thermocouple response? ISA J. 7, 56 (Aug.).

Premak, W., and E. Edwards, Large recording potentiometer errors caused by furnace leakage currents, Rev. Sci. Instr. 31, 1242 (Nov.).

Ross, G. S., and H. D. Dixon, Automatic precise recording of temperature, J. Res. Natl. Bur. Std. (U.S.) 64C, 271.

Sirota, A. M., et al., Methods of testing thermocouples and thermocouple wires, Ind. Lab. 26, 126 (Jan.).

Multipoint temperature scanner, Engineer 209, 693.

USN develops new thermowell for high-velocity steam, ISA J. 7, 34 (Nov.).

\section{1}

Accinno, D. J., A vacuum furnace for high temperature thermocouple calibration, Engelhard Ind., Tech. Bull. 2, 16 (June).

Andreev, S. V., B. K. Martens, and A. N. Trushinskii, Transistorized instrument for remote measurement and control of temperature, Measurement Techniques No. 11,882 (Nov.).

Antier, G., A thermostatic enclosure for thermocouples, Mesur. Control Ind. No. 294, 1335 (Nov.).

Avdeev, A. I., D. A. Ilmenskii, and M. D. Notarius, Application of asymmetrical bridge in electromagnetic measuring instruments for resistance thermometers, Instr. Construct. No. 6, 1 (June).

Beerman, H. P., High temperature black body radiation source, Bull. Am. Ceram. Soc. 40, 308 (May).

Bratkowski, W., Flast-response temperature controls, Prod. Eng. 32, 40 (May 29).

Freeman, R. J., Thermoelectric stability tests, General Electric Co., Nuclear Mater. and Propulsion Operation, Cincinnati, U.S. At. Energy Comm. APEX-746 (Aug.).

Godin, M. C., Simple bridge for the direct measurement of temperature differences, J. Sci. Instr. 38, 330 (Aug.).

Green, B. A., Simple ac resistance bridge using a dc breaker amplifier, Rev. Sci. Instr. 32, 364.

Kayander, M. S., Differential instrument for comparing radiation pyrometers, Measurement Techniques No. 2, 119 (Feb.).

Middlehurst, J., Mercury switch for establishing the true electrical zero in precise thermocouple measurements, J. Sci. Instr. 38, 165 (Apr.).

Moodie, W. C., Thermal switches and transducers for discreet and continuous temperature control, Space Aeronautics 36, 127 (July).

Nalle, D. H., Accurate recordings of fast-changing temperatures, ISA J. 8, 58 (June).

Pak, V., Computation of the basic parameters for a telescope of a radiation pyrometer with a thermistor, Measurement Techniques No. 12, 879 (Dec.).

Seshadri, T. N., and S. P. Jain, A constant ice point junction for thermocouples in continuous use for long periods, J. Sci. Ind. Res. (India) 20D, 161 (Apr.).
Simmons, F. S., A. G. De Bell, and Q. S. Anderson, A $2000^{\circ} \mathrm{C}$ slit-aperture blackbody source, Rev. Sci. Instr. 32, 1265 (Nov.).

Sutcliffe, J., Direct-reading resistance-thermometer bridge, Instr. Control Systems 34, 293 (Feb.).

Testardi, L. R., and G. K. McConnel, Measurement of the Seebeck coefficient with small temperature differences, Rev. Sci. Instr. 32, 1067 (Sept.).

\section{2}

Ballard, G. G., Transistor thermocouple trip amplifer, J. Brit. Inst. Radio Engrs. 23, 35 (Jan.).

Bansal, T. D., Calibration equipment for surface pyrometers and pipe thermometers, J. Sci. Instr. 39, 232 (May).

Belling, P. R., High-pressure thermocouple feed-through, Instr. Control Systems 35, 119 (Nov.).

Benedict, B. V., Vibration test of thermocouple type 300RD P/N 8968365, ASTIA AD-275 686 .

Bose, B. N., Thermocouple well design, ISA J. 9, 89 (Sept.).

Boudreaux, P. J., Providing thermocouple compensation at low cost, Electronics 35, 72 (Nov.).

Bridle, J. A., and J. I. Morgan, High-speed temperature recording, J. Iron Steel Inst. (London) 200, 318 (Apr.).

Brownwood, J. B., Thermocouple compensating circuit design, Electronics 35, 98 (Jan. 5).

Cameron, G., and R. L. Blanchard, Design and operation of a pressure-type cryostat for thermometer calibration in the liquid-hydrogen region, ISA Trans. 1. 255 (July).

Greenwood, T. L., Indicator warns of excessive rise rates, Electronics 35, 54 (Feb.).

Katadeladze, K. S., E. N. Zedginidze, and T. V. Nozadze, Thermocouple immersion tips for measuring the temperature of molten metals, Ogneupory 27, 223.

Katateladze, K. S., E. N. Zedginidze, and P. A. Pirumova, Thermocouple protection tubes made of carborundum with a nitride binder, Stal 22, 237.

Kocho, V. S., A. D. Panasyuk, G. V. Samsonov, A. G. Strelchenko, and I. G. Khavrunyak, Zirconium boride cermet protection tubes for thermocouples, Stal 22, 317.

Lash, J. B., Inexpensive testing for precision sensors, Instrumentation $15,4$.

MacDonald, W. R., Simple amplifier for use with metalflm thermometers in timing applications, J. Sci. Instr. $39,35$.

Mandt, R. D., Fusing thermocouple leads, ISA J. 9, 82 (Nov.).

McAllan, J. V., Selector switch to avoid transient selfheating in resistance thermometers, J. Sci. Instr. 39, 447.

Manigan, J., and E. J. Nichols, Thermocouple sensing tip, Mater. in Design Eng. 55, 147 (Apr.).

Pitts, E., and P. T. Priestly, Constant sensitivity bridge for thermistor thermometers, J. Sci. Instr. 39, 75 (Feb.).

Priem, M., Method for sealing thermocouple wire through fused silica for use at high temperature, J. Sci. Instr. 39, 130 (Mar.).

Ramage, R. V., Ultra-high pressure seals for instrumentation leads, Design Eng. 55, 156 (May).

Rautio, W. S., Metal-sheathed ceramic-insulated thermocouples; swage or draw?, Instr. Control Systems 35, 101 (May).

Samsonov, G. V., P. S. Kislyi, and A. D. Panasyuk, Zirconium boride tips for immersion thermocouples, ASTIA AD-283 891.

Sondericker, J., Zener diodes replace thermacouple icejunction, Electron. Design 10, 42 (Feb. 1).

Thomas, D. B., A furnace for thermocouple calibrations to $2200^{\circ} \mathrm{C}$, J. Res. Natl. Bur. Std. (U.S.) $66 \mathrm{C}, 255$.

Turco, J. F., J. Hickey, and I. Bar-Gadda, Sample holder for use in the measurement of thermoelectric power of thermoelectric materials, Rev. Sci. Instr. 33, 384 (Mar.).

Whiteway, S. G., Sintering long thermocouple sheaths without warping, Am. Ceram. Soc. Bull. 41, 95 (Feb. 15). 
Wright, H. C., A thermocouple slide-rule, J. Sci. Instr. 39, 238 (May).

An improved resistance thermometer bridge, Instr. Pract. 16, 191 (Feb.).

Improved resistance-thermometer bridge, Electro-Technol. (New York) 70, 146 (Oct.).

Sealing thermocouples in pressure vessels, Engineering 193,4 .

Time temperature integration device, General Electric Co., ASTIA AD-271 416.

\section{General}

\section{8}

Frost, F. E., High temperature production and measurement-a bibliography, Lawrence Radiation Lab., Univ. Calif., Livermore, Calif., UCRL-5409.

\section{9}

Allegre, R., et al., Etudes de Pyrometrie pratique, Editions Eyrolles, Paris.

Bayley, H. G., Recent developments in the precise measurement of temperature, J. Inst. Engrs. Australia 31, 227 (Sept.).

Hurwitz, H., Review of methods for measuring temperatures up to $20,000^{\circ} \mathrm{K}$, Naval Ordnance Lab., White Oak, Md., NAVORD-6680 (July 6) ; ASTIA AD-232 698; PB 154722 (LC).

Lier, R. H., High temperature measuring techniques 1948 to present (bibliography), U.S. Sci. Lab. Los Alamos, LAMS-2325.

McCoy, E., Bibliography on gas temperature measurement, United Kingdom At. Energy Authority, I. G. information series 68 (RD/CA).

Strelkov, P. G., and D. I. Sharevskaya, Results of comparing temperatures calculated by the $M$ SH $T$ and the comparison method, Measurement Techniques No. 2, 124 (Feb.).

Theoretical and experimental research in thermoelectricity (Dec.), PB 161468.

1960

Angello, S. J., Recent progress in thermoelectricity, Elec. Eng. 79, 353 (May).

Beltran, A. A., A preliminary literature survey. High temperature strain and temperature sensing devices, Lockheed Aircraft Corp., Missiles and Space Division, Special bibliography SB-60-3.

Combes, J. J., Temperature measuring devices, Automation 7,87 (May).

Coxon, W. F., Temperature measurement and control, Macmillan, N.Y.; Heywood and Co., London.

Grimes, W. R., and D. R. Cuneo, eds., High temperature thermometry seminar, held Oct. 1-2, 1959 at Oak Ridge Natl. Lab., U.S. At. Energy Comm. TID-7586 (pt. 1) (Aug.).

Hedge, J. C., et al., Temperature measuring techniques, Wright Air Develop. Div., Wright-Patterson AFB, WADD-TR-60-487 (June) ; ASTIA AD-253 483.

Jackson, E. W., Temperature measurement and control, Chem. Process Eng. 41, 139 (Apr.).

Kebbons, E. R., Miscellaneous temperature-measuring methods, Instr. Control Systems 33, 1921 (Nov.).

Kostkowski, H. J., The accuracy and precision of measuring temperatures above $1000^{\circ} \mathrm{K}$, International Symposium on high temperature technology, Asilomar conference grounds, Calif., Oct. 5-9, 1959, McGraw-Hill Book Co., N.Y., 1960, p. 33.

Meyer-Wittig, O., Calculation for determining the response lag of temperature probes under periodic changes of temperature, Electrotech. 38, 501 (Sept. 29).

Plumb, H. H., Secondary thermometry grows more precise, Chem. Eng. News 38, 40 (Oct. 31).

Stewart, L., How to handle the problem of measuring low temperature, Power 104, 208 (Nov.).
Werner, F. D., Total-temperature measurements, Instr. Control Systems 33, 800 (May).

Thermoelectricity abstracts (Mar.), PB 161301 (OTS).

Thermoelectricity abstracts, PB 161174 (Dec.).

Thermoelectricity, OTS selective bibliography SB-432 (Sept.).

Thermopiles and thermocouples, OTS selective bibliography SB-430 (Aug.).

\section{1}

Awano, M., Precisionization of gas thermometry, J. Phys. Soc. Japan 16, 2560.

Baker, H. D., E. A., Ryder, and N. H. Baker, Temperature measurement in engineering, Vol. II, John Wiley \& Sons, Inc., N.Y.

Brinich, P. F., Recovery temperature, transition and heattransfer measurements at Mach 5, NASA Tech. Note D-1047.

Danlouz-Dumensnils, M., From the Florentine thermom eter to that of Lyons, Mesur. Control Ind. 26, 1023 (Sept.).

Kallen, H. P., Handbook of instrumentation and controls, McGraw-Hill Book Co., N.Y.

Kennedy, J. H., et al., High temperature measurement and production-a bibliography, Lawrence Radiation Lab. Univ. Calif., Livermore, Calif., UCRL-6424.

Pivovonsky, M., and $M$. Nagel, Tables of blackbody radiation functions, Macmillan Co., N.Y.

Snyder, P. E., Chemistry of thermoelectric materials, Chem. Eng. News 39, 102 (Mar. 13).

Sterrett, S. J., Improved manufacturing techniques for blood-flow probes, J. Sci. Instr. 38, 59 (Feb.).

Upton, Jr., E. F., Measuring industry's hot spots, Plant Eng. 15, 117 (Oct.) ; 109 (Nov.).

Yaryshev, N. A., Inertial parameters of resistance thermometers and thermocouples, Measurement Techniques No. 9, 716 (Sept.).

Yeaple, F., a new look at temperature-measuring transducers, Prod. Eng. 32, 49 (May 22).

The platinum metals in temperature measurement, Platinum Metals Rev. 5, 89 (July).

\section{2}

Ball, I. D. L., Temperature-measurement techniques discussed, R\&D No. 13, 30 (Sept.).

Coombe, R. A., Measuring temperature and Mach number in a high temperature gas flow, R\&D No. 15, 38 (Nov.).

Hertzfeld, C., ed. in chief, Temperatures, its measurement and control in science and industry. Volume 3 , part 1 , Basic concepts, standards and methods, F. G. Brickwedde, ed.; Volume 3, part 2, Applied methods and instruments, A. E. Dahl, ed., Rheinhold Pub. Corp., N.Y.

Holland, M. G., L. G. Rubin, and J. Welts, Temperature measurement from $2^{\circ} \mathrm{K}$ to $400^{\circ} \mathrm{K}$, Instr. Control Systems 35, 89 (May).

Holzbock, W. G., Instruments for measurement and control, 2nd ed., Reinhold Pub. Corp., N.Y.

Hunter, J. J., Precision temperature measuring equipment, J. Brit. Inst. Radio Engrs. 24, 251 (Sept.).

Huovila, S., Contributions to the measurement and interpretation of small-scale temperature fluctuations, Academic Bookstore, Helsenki, Finland.

Katz, A. J., Thermal testing, Space-Aeronautics 38, 30 (Oct.).

Lathrop, P., Technique for temperature measurement, Ind. Phot. 11, 12 (Mar.).

Liddiard, F. E., and J. H. Heath, Temperature measurement, Control, part 1, 5, 95 (Sept.) ; part 2, 5, 109 (Oct.) ; part 3, 5, 110 (Nov.).

Lieneweg, F., Temperature measurement, Arch. Tech. Messen No. 313, 47 (Feb.).

White, F. J., Accuracy of thermocouples in radiant-heat testing, Exp. Mech. 2, 204 (July).

Yarishev, N. A., and A. S. Makhnovetskiy, Errors in the measurement of transient surface temperatures, ASTIA AD-265 800. 
Bibliography of Temperature Measurement January 1963 to December 1965

\section{Lief 0. Olsen and Carl Halpern}





\title{
BIBL IOGRAPHY Of TEMPERA TURE MEASUREMENT
}

\author{
January 1963 to December 1965
}

\section{Lief 0. OIsen and Carl Halpern}

There are presented in this supplement to NBS Monograph 27. "Bibliography of Temperature Measurement, January 1953 to June 1960" issued April 6, 1961 and Supplement 1, July 1960 to December 1962 issued September 13, 1963, about 1200 additional references to the field of temperature measurement. The period covered is from January 1963 to December 1965 with some earlier references which came to our attention. With the exception of Part 1 which has been changed to include theory; calibration and temperature scales, the arrangement of material is the same as in Monograph 27. The journal abbreviations used are those employed in Chemical Abstracts.

Key words: Temperature, thermometry, thermocouples,

thermistors, resistance thermometer, and radiation pyrometry

\section{INTRODUCTION}

The material contained herein was collected from two general sources: scientific and technical journals and reports of investigations sponsored or conducted by various governmental agencies. English, German, and French journals and translations in English of Russian journals were covered as well as the more commonly used abstract journals. Some references to material in other languages, obtained from the abstract journals, are also included. To obtain references to governmental reports the following were consulted: Technical abstract Bulletin. Armed Services Technical Information Agency; Scientific and Technical Aerospace Reports, National Aeronautics and Space Administration (NASA); Nuclear Science Abstracts, United States Atomic Energy Commission; and U.S. Government Research Reports, Office of Technical Information, U.S. Department of Commerce. While reasonably complete coverage was intended, it is inevitable that oversights and other unintentional omissions have occurred.

The topical subdivisions are shown in the table of contents. Each subdivision is arranged chronologically and within the chronological sections, alphabetically by author. "Anonymous" articles appear at the end of each section.

The period covered is from January 1963 to December 1965 with some earlier entries which had been overlooked in the original bibliography NBS Monograph 27 and its first supplement.

The journal abbreviations used are those employed in Chemical Abstracts. Volume numbers are underlined and date of issue is given where page numbers do not run consecutively throughout a given volume. Since the year of issue apears at the head of each chronological section, this is not repeated in the individual references.

Numbers prefixed by the letters $A D$ refer to report numbers in the Technical $A b-$ stract Bulletin; those by N63, N64, and N65 are identifying numbers in the Scientific and Technical Aerospace Reports; and those by NSA refer to the report numbers in Nuclear Science Abstracts. 
1. Theory, Calibration and Temperature Scales

1958

Lowenthal, G.C., W.R.G. Kemp and A.F.A. Harper, Temperature scale down to $20^{\circ} \mathrm{K}$ using platinum resistance thermometers, Low Temp. Phys. Thermodyn., Proc. Meeting Comm. I Intern. Inst. Refrig., Delft, Neth., 107 .

\section{0}

Aryhanov, A. S., A. N. Gordov, and U. V. Di ikov, A new determination of the melting point of gold, Tr. Vses. Nauchn.Issled. Inst. Metrol., 49, 5.

\section{1}

Hudson, R. P., Low temperature thermometry, ExptI. Cryophys. 1961, 213.

Sherman, R. H., T. R. Roberts, and S. E. Sydoriak, Helium- 3 vapour pressures: a standard for improved thermometry below $1{ }^{\circ} \mathrm{K}$, Bull. Inst. Intern. Froid, Annexe $5, \underline{1961}, 125$.

\section{2}

Barber, C.R., Boiling points of hydrogen, Comite Consultatif Thermometrie, Comite Intern. Poids Mesures, 6e, Sevres, France, 1962, 97.

Bragin, B. K., Solidification point of copper, Measurement Techniques No. 3 , $214\left(\operatorname{sep} t^{\prime}\right)$.

Brodsky, A. D., V. P. Kemlevsky, and A.V. Savateev, New methods of realizing the thermodynamic scale in the low temperature region, Comite Consultatif Thermometrie, Comite Intern. Poids, Mesures, $6 e$, Sevres, France, 1962, 171.

Jaumot, F.E., Thermoel $\overline{\text { ectr }}$ icity, Advanced Electron. and Electron Phys. 17, 207.

Kirenkov, I.l., et al, New measurements of the thermodynamic temperatures of the reference points of tin, cadmium $z$ inc and gold, I zmeriteln. Tekhn. No. 9,31 .

Kirenkov, 1. 1., Investigation of thermodynamic temperature reference points, Measurement Techniques No. 4, 286 (Sept.).

Pak, V., Calibration of thermocouples in a dynamic condition, Measurement Techniques No. 6,475 (Dec.).

Sherman, R. H., T 62 Hel i um- 3 temperature scale IV. Tables, U.S. At. Energy Comm. LAMS - 2701 .

\section{3}

Benedict, R.P., The generation of thermocouple reference tables, Electro-Techno logy $\left(N_{.} Y_{.}\right)$72, 80 (Nov.).

Benedict, R. P., and H. F. Ashby, Emperical determination of thermocouple characteristics, Trans. ASME (J.Eng. Power) 85A, 9 .
Benedict, R.P., and J.W. Murdock, Steadystate thermal analys is of a thermometer well, Trans. ASME (J. Eng. Power) 85A, 235.

Bonanno, A. M., Commercial laboratory temperature calibrating services with reference traceable to the National Bureau of Standards, Proc. Instr. Soc. Am. 18 Paper No. 57-2-63.

Bragin, B.K., Calibration of standard thermocouples at the freezing point of copper, Tr. Inst. Kom. Standartov, Mer i Izmerit. Priborov pri Sov. Min. SSSR $1963,97$.

Brickwe Jde, F. G., International practical temperature scale, Phys. Today 16, 24 (May).

Brindley, J.H., Calibration of surfaceattached thermocouples on a flat-plate fuel element by electrical analogue and analytical techniques, Trans. Am. Nucl. Soc. 6, 333 (Nov.).

BrodskiT, A. D., V. P. Kremlevskii, and A. $V$. Savateev, New methods of producing the thermodynamic scale at low temperatures, Measurement Techniques, No. 9, 757 (Apr.).

Gramburg, G., and H. G. Flust, Developments in the field of thermoelectricity, Naval Engrs. J. 75, 925 .

Hall, J.A., Role of the platinum-resistance thermometer in the International Practical Scale of Temperature, Proc. Inst. Elect. Engrs. 110, 1502 (Aug.).

Kamochkina, E. M., and N. N. Ergardt, Constant solidification point of palladium,

$\mathrm{Tr}$. Inst. Kom. Standartov, Mer i Izmerit. Priborov pri Sov. Min. SSSR No. 71, 237.

Kirenkov, 1.1., New evaluation of the thermodynamic temperatures of the $t i n$, cadmium, zinc and gold reference points, Measurement Techniques No. 9, 752 (April).

Kirenkov, 1. 1., The thermodynamic and the international practical temperature scales, Z. Instrumentenk. 71, 43 (Feb.).

Kocherzhinski $i, Y u$. $\bar{A}$., et al, Calibration of the VR - 5/20 thermocouple by critical points up to $3000^{\circ}$, Sb Nauchn. Tr. Inst. Metallfiz., Akad. Nauk Ukr. SSR No. 17,200 .

Lovejoy, D. R., Some boiling and triple points below $0^{\circ} \mathrm{C}$, Nature 197, 353 ( Jan. 26).

Lucke, W. H., A brief survey of elementary thermoelectric theory, NRL Rept. 5880 (May), AD-405854; N 64-20326.

McLaren, E. H., and E. G. Murdock, The Freezing points of high purity metals as precision temperature standards. VII Thermal analysis on seven samples of bismuth with purities greater than $99.999 \%$, Can. J.Phys. 41, 95 (Jan.).

NuI I, M. R., and W. W. Lozier, Carbon-arc radiation standard, Instr. Control Systems 36, 93 (May).

Rebiene, J., R. Beranger, and P. Perroud, Calibration of thermocouples for low temperatures, Comm. Energie At. (France) Note No. 418.

Rechter, M., Use of high purity materials in thermometry, Reinsts tof fe wiss. Tech., Intern. Symp., 1, Dresden 1961, 345 . 
Swindells, J.F., Calibration of temperature measuring instruments at the NatI. Bur. of Std., Misc. Publ. U. S. Bur. Stand. 240 (Aug. I6).

Sydoriak, S. G., T. R. Roberts, and R. H. Sherman, The $\mathrm{T}_{62}$ "Helium- 3 temperature scale, Proc. Intern. Conf. Low temp. Phys., 8th. London 1962, 437; Low Temperature Physics, Butterworth's Washington, D.C. (1963), 437 .

Van Dijk, H., Units of temperature and temperature scale, Z. Angew. Phys. 15, 561 (June).

Calibration of temperature measuring instruments at the NatI. Bur. of Std., Engineer 215, 501 .

Temperature calibrations, Instr. Pract. 17. 190 (Feb.).

The international Committee on Weights and Measures, Nature 197, 1055 (Mar. 16).

\section{4}

Astrov, D.N., M.P. Orlova, and D. I. Sharevskaya, Extension of the practical international scale of temperature below $-182.97^{\circ}\left(90.18^{\circ} \mathrm{K}\right)$, Comite Consultatif Thermometrie, Comite Intern. Poids Mesures, 6e, Sevres, France 1962, 102.

Bedford, R.E., Reference tables for platinum 20\% rhodium/platinum 5\% rhodium thermocouples, Rev. Sci. Instr. 35 , 1177 (Sept.).

Blackburn, G.F., and F.R. Caldwell, Reference tables for thermocouples of iridium- rhodium alloys versus iridium, J. Res. Natl. Bur. Std. (U.S.) 68C, 41 (jan.-Mar.).

Bonilla, C.F., et al, Thermoelectric potentials of molten and refractory metals, N 64-20479.

Davisson, E.G., and R.K. Adams, Smoothed thermocouple tables, U.S. At. Energy Comm. Rept. ORNL-P-227; Proc. Instr. Soc. Am. 19, Paper No. 11, 1-3-64.

Eisenstein, J.C., R.P. Hudson, and B. W. Mangum, A magnetic fixed point for thermometry below $10^{\circ} \mathrm{K}$, Appl. Phys. Letters 5, 231 (Dec. 1 ).

Georgian, J.C., The temperature scale, Nature 201, 695 (Feb. 15).

Hall, J.A., The pyrometric scale of temperaturebetween 20 and $1063^{\circ}$, Comite Consultatif Thermometrie, Comite Intern. Poids Mesures, 6e, Sevres, France 1962, 72.

Hall, J.A., and C.R. Barber, Calibration of temperature measuring instruments, Nat'I. Phys. Lab. (Gt. Brit.) Notes Apol. Sci. No. 12 (3rd.ed.).

Hauback, W.j., and W.L. Taylor, Measuring precisely near absolute zero; helium- 3 and low temperature thermometry, Research/Development 15, 19 (Sept.).

Hensinkveld, W.A., and K. Scheerer, Comparison of the pyrometric scale of temperature of the University of Utrecht to those of N.P.L. and of P.T.B., Comite Consultatif Thermometrie, Comite Intern. Poids Mesures, 6e, Sevres, France, 1962, 67 .
Heyne, W., Precision measurement for testing thermoelectric voltages and temperature relationshios of $\mathrm{Pt}-10 \% \mathrm{Rh} / \mathrm{Pt}$ thermoelements by means of the solidification points of copper, aluminum and zinc, Feingeratetech. 13, 311 (July).

Heyne, W.., Investigation of the determination of the relation of thermal emf and temperature of $\mathrm{Pt} 10 \% \mathrm{Rh}$ vs $\mathrm{Pt}$ thermocouples by means of the freezing points of metals, Exptl. Tech. Physik 13, 90.

Heyne, W., Determination of the freezing point of copper. ExptI. Tech. Physik 12,

Lapp, G.B., and D.J. Popova, Calibration of tungsten-rhenium thermocouples, Measurement Techniques No. 10, 847 (Mar.).

Le Fevre, E.J., The temperature scale, Nature 203, 1158 (Sept. 12).

Love joy, D.R., Theory of two bands for high purity platinum and the reproducibility of the temperature scale, Comite Consultatif Thermometrie, Comite Intern. Poids Mesures, 6e, Sevres, France, 1962, 138.

Magdeburg, H.. A new method for realizing pyrometric fixed points, $Z$. Instrumentenk $72,205(\mathrm{Ju} \mid \mathrm{y})$.

Minard, D., Effective temperature scale and its modification, Naval Medical Research Inst. Bethesda, Md., Rept. 6, (Mar.); $A D-603186$; N64-30629.

Moser, H., and W. Thomas, Comparison of the practical international temperature scale with the thermodynamic scale between the $z$ inc and gold points according to the most recent gas thermometer measurements, Comite Consultatif Thermometrie, Comite Intern. Poids Mesures, 6e, Sevres, France $1962,34$.

olsen, L.O., and P.D. Freeze, Reference tables for the Platinel II Thermocouple, J. Res. Natl. Bur. Std. (U.S.) 68C, 263 (oct.).

Roberts, T.R., et al, The 1962 Helium- 3 scale of temperatures, U. S. At. Energy Comm. Rept. LADC- 5757 .

Sherman, R. H., et al, 1962 Helium- 3 scale in 4 parts, NBS Journal 68A, pp 547, 559, 567 , \& 579 .

Spengler, W.E., and D.K. Graham, Equations and tables for thermocouples, $32^{\circ} \mathrm{F}$ reference junction, AD-432828; N64-17456.

Sydoriak, S.G., et al, The 1962 Helium-3 scale of temperature, J. Res. Natl. Bur. std. (U.S.) 68A, 547 .

\section{5}

Adams, R.K., and E.G. Davisson, Smoothed Thermocouple tables of extended significance $\left({ }^{\circ} \mathrm{C}\right)$ : platinum vs platinum-10\% rhodium thermocouples, Oak Ridge NatI. Lab., Tenn. Instrumentation and Controls Div., ORNL - 3649, Vol. 2, Sect. 2.1 (Mar.); AD 19-20263; N65-20680.

Adams, R.K., and E.G. Davisson, Smoothed thermocouple tables of extended significance $\left({ }^{\circ} \mathrm{Cl}\right.$ : platinum vs platinum-13\% rhodium thermocouples, ORNL-3649, Vol. 2, Sect. 2.2; AD-20264; N65-20681. 
Adams, R.K., and E.G. Davisson, Smoothed thermocouple tables of extended significance $\left({ }^{\circ} \mathrm{C}\right)$ : Chromel-Alumel thermocouples, ORNL-3649, Vol. 2, Sect. 2.3: AD20265: N65-20682.

Adams, R.K., and E.G. Davisson, Smoothed thermocouple tables of extended significance $\left({ }^{\circ} \mathrm{C}\right)$ : iron-constantan thermocouples, ORNL-3649, Vol. 2, Sect.2.4; AD20266; N65-20683.

Adams, R.K., and E.G. Davisson, Smoothed thermocouple tables of extended significance $\left({ }^{\circ} \mathrm{C}\right)$ : copper-constantan thermocouples, ORNL-3649, Vol. 2, Sect. 2.5; AD-20267: N65-20684.

Adams, R.K., and E.G. Davisson, Smoothed thermocouple tables of extended significance $\left({ }^{\circ} \mathrm{C}\right)$ : Chromel-constantan thermocouples, ORNL-3649, Vol. 2, Sect. 2.6: $A D-20267$ : N65-20684.

Adams, R.K., and E.G. Davisson, Smoothed thermocouple tables of extended significance $\left({ }^{\circ} \mathrm{C}\right)$ : tungsten vs tungsten- $26 \%$ rhenium thermocouples, ORNL-3649, Vol. 2, Sect. 2.7; AD-20269; N65-20152.

Adams, R.K., and E.G. Davisson, Smoothed thermocouple tables of extended significance $\left({ }^{\circ} \mathrm{C}\right)$ : tungsten $-5 \%$ rhenium vs tungsten-25\% rhenium tehrmocouples, ORNL-3649, Vol.2, Sect. 2.8; AD-20270; N65-20153.

Adams, R.K., and E.G. Davisson, Smoothed thermocouple tables of extended significance $\left({ }^{\circ} \mathrm{C}\right)$ : tungsten- $3 \%$ rhenium vs tungsten-25\% rhenium thermocouples, ORNL-3649, Vol. 2, Sect. 2.9; AD-20271; N65-20154.

Adams, R.K., and E.G. Davisson, Smoothed thermocouple tables of extended significance $\left({ }^{\circ} \mathrm{C}\right)$ : gold-2.1\% cobalt vs copper cryogenic thermocouples, ORNL-3649, Vol. 2, Sect. 2.10; AD-20272; N65-20155.

Adams, R.K., and E.G. Davisson, Smoothed thermocouple tables of extended significance $\left({ }^{\circ} \mathrm{C}\right)$ : constantan-copper cryogenic thermocouples, ORNL-3649, Vol. 2, Sect. 2.11; AD-20273; N65-20156.

Adams, R.K., and E.G. Davisson, Smoothed thermocouple tables of extended significance $\left({ }^{\circ} \mathrm{C}\right)$ : Alumel-Chromel cryogenic thermocouples, ORNL-3649, Vol.2, Sect. 2.12; AD-20274; N65-20157.

Adams, R.K., and E.G. Davisson, Smoothed thermocouple tables of extended significance $\left({ }^{\circ} \mathrm{C}\right)$ : constantan (JN)-iron (JP) cryogenic thermocouples, ORNL-3649, Vol. 2, Sect. 2.13: AD-20275; N65-20158.

Adams, R.K., and E.G. Davisson, Smoothed thermocouple tables of extended significance $\left({ }^{\circ} \mathrm{C}\right)$ : constantan $(Y N)-\operatorname{iron}(Y P)$ cryogenic thermocouples, ORNL-3649, Vol. 2, Sect. 2.14; AD-20276: N65-20159.

Barber, C.R., and A. Horsford, Differences between the thermodynamic scale and the International Practical Scale of Temperature from $0^{\circ} \mathrm{C}$ to $-183^{\circ} \mathrm{C}$, Metrologia 1, 75 (July).

Beattie, J.A., et al, Experimental study of the absolute temperature scale, J. Chem. Phys. 42, 2274 (Apri).

Bedford, R.E., Reference tables for plat- inum $40 \%$ rhodium vs platimum $20 \%$ rhodium thermocouples, Rev. Sci. Instr. 36, 1571 (Nov.).

DeBoer, J., Temperature as a basic physical quantity, Metrologia, 1, 158 (oct.).

Dingle, H., et al, Linear temperature scale, Nature 206, 1347 (June 26).

Furukawa, G.T., and M.L. Re i $|l y, A p p|$ ication of precise heat capacity data to the analysis of the temperature intervals of the NBS (1955) and the international practical temperature scales in the region of $90^{\circ} \mathrm{K}, \mathrm{J}$. Res. Nat'l. Bur. Std. (U.S.) 69A, 5 (jan.).

Grenis, A.F., and M.J. Matkovich, Blackbody reference for temperatures above $1200^{\circ} \mathrm{K}:$ Study for design requirements, Army Material Research Agency, Watertown, Mass., Tech. Rept. AMRA-TR-65-02; AD614638.

Groves, W.D., and L. Lielmezs, The 1 inear temperature scale, Nature 205, 489 IJan. 301 .

Hall, J.A., The radiation scale of temperature between $175^{\circ} \mathrm{C}$ and $1063^{\circ} \mathrm{C}$, Metrologia 1,140 (Oct.).

MarshaTI, T.W., A classical treatment of blackbody radiation, Nuovo Cimento( 1 taly) 38,206 ( July 1 ).

Rath, R., and R. Dubbe, Pyrometers and their calibration for production control, Fe i nwk.- Tech. 69, 97 (March).

\section{Thermoelectric Devices}

1950

Adakhovskii, A.P., et al, New types of thermocouples for measuring temperatures up to $1800^{\circ}$, Tr. Vses. Nauchn.- Issled. Inst. Metrol. 1960, No. 42, 29.

Ciborowski, F., The effect of non-homogeneous thermocouple elements on the accuracy of $\mathrm{NiCr}-\mathrm{Ni}$ thermocouples, Prom. Avtomat. Kontrol 1960, No. 2, 64 .

Kuether, F.W., The thermal emf scatter of rhenium, Rhenium Papers Symp., Chicago, $1960,149$.

Lachman, J.C., and J.A. McGurty, Thermocouples for $5000^{\circ} \mathrm{F}$, using rhenium alloys, Rhenium Papers Symp., Chicago 1960, 153.

L'vov, S.M., and V.F. Nemchenko, Tungstenmolybdenum thermocouple, Ezhegodnik Nauchn. Rabot, Khersonsk. Gos. Ped. Inst., Estestvoznanie, Kherson 1960, 3.

Moeller, G.K., R.B. Branfi $\overline{n,}$ and $P$. Whitmarsh, Error determination in high temperature thermocouple measurements, U.S. At. Energy Comm. Rept. K-T-552, (Nov. 30); NSA $18-12418$.

\section{1}

Green, S.J., and T.W. Hunt, Accuracy and response of thermocouples for surface and fluid temperature measurement, U.S. At. Energy Comm. Rept. WAPD- T-1270.

1962

Begot, R., and R. Faivre, Experimental 
study of the very rapid cooling obtained by direct quenching in water of solders on thermocouples, Compte Rend. 255, 3128 (Dec. 5).

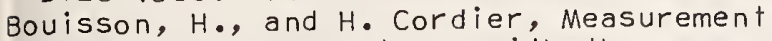
of surface temperatures with thermocouples. Effect of radiation received by the thermocouple and the method of attachment, Compt Rend. Acad. Sci. 255, 1296 (Aug. 27).

Challe, J., Study of the dynamic behavior of thermowelis, U.S. At. Energy Comm. Rept. NP-13288 (Sept.).

Cherpakov, P.V., The thermal inertia of thermocouples, Inzh. Fiz. Zh. 5, 94 (Sept.).

Ciborowski, F., Factors affecting constancy and stability of the thermoelectric characteristics of industrial thermocouples, Pomiary, Automat., Kontrola 8 , 509 (Nov.).

Doyle, J., High voltage electron beam welding of $W$ - Re thermocouples, U.S. At. Energy Comm. Rept. CNLM-4351 (Dec. 13). Fitzpatrick, V.F., Fretting corrosion of $1 / 8$ - inch $\mathrm{Zr}-2(\mathrm{Zy}-2) \mathrm{clad}$ thermocouples, U.S. At. Energy Comm. Rept. HW75626 (Nov.).

Golubev, A.V., Influence of the electrochemical effect in thermocouples on the precision of temperature measurements, Materialy k Ucheniyu o Merzlykh Zonakh Zemnoi Kory., Akad. Nauk SSSR, Akad. Stroit. i Arklritekr., Inst. Merzotored. 8, 113.

Kärasina, E.S., L.I. Kropp, and M.S. Mints Aplication of suction thermocouples for measuring high gas temperatures, Ind. Lab. 23, 665 (Dec.).

Kortum, H., G. Luck, and E. Stutter, Resistance measurement on thermocouples and thermopiles, Feingeratetech. 11, 534 (Dec.).

Kroeckel, 0., High-temperature thermoelements, Abhandl. Deut. Akad. Wiss. BerI in, Kl. Math., Physik. Tech. 1962, No. 1,437 .

Kutateladze, K.S., et al, Sheaths for immersion thermocouples for measuring the temperature of molten metals, ogneupory $27,223$.

Margulis, O.M., et al, Tips for immersion type thermocouples made from zirconium dioxide of increased res istance to heat, ogneupory 12, 552; AD-411058.

McGurty, J.A., and W.C. Kuh Iman, Tungsten vs tungsten-rhenium thermocouple research and development, U.S. At. Energy Comm. Rept. TID-20944.

Morita, Y., Average temperature measurements using thermocouples, Bull. Tokyo Inst. Technol. No. 50, 27.

olszewski, J., Effect of thermocouple sheathing on reading temperatures of blast-furnace blast, Hutnik 29, 366.

owczarski, W.A., Tungsten-rhenium thermocouples for difficult measurements of Zircalloy-2 wel dments, U.S. At. Energy Comm. Rept. TID-17734.

Plyukhin, V.S., and V.N. Kologrivov, Emf of thermocouples compressed by a shock wave, Zh. Prikl. Mekhan. i Tekn. Fiz. No. 5, 175 (1962); A ir Force Systems Command, Wright Patterson AFB, Ohio, Foreign Technology Division FTD-TT-63-1057/1 and 2; AD-426901; N64-23314.

Shaidurov, G.F., Measurement of the temperature of a wall, Inzh. Fiz. Zh. ㄴ, 86 (Dec).

stottman, P., Measuring high temperature gas flames with thermoelectric elements, Wiss. Ges. Luft - u Raumfahrt, Cologne (w. Germany) Proc. of the joint meeting of the Comm. on air-breathing engines, and the subcomm. on areodynamic measuring techniques (july 6, 1962); N64-20181.

Vasanova, L.K., et al, The measurement of temperature in poly-dispersion media during induction heating, Inzh. Fiz. Zh. 5, 82 (April).

W-Re takes Zircalloy-2's temperature, Am. Machinist 106, 122 (Nov.).

\section{3}

Adorni, N., and A. Parmaggiani, Device for high accuracy measurement of wall temperature using thermocouples, Energia Nucl. 10,34 .

Berman, R., and D.J. Huntley, Dilute goldiron alloys as thermocouple material for low-temperature heat conductivity measurements, Cryogenics 3 , 70.

Bertodo, R.J., A thermocouple for the measurement of gas temperatures up to $2000^{\circ} \mathrm{C}$, Proc. Inst. Mech. Engrs. (London) 177, 603.

Bertodo, R.J., Thermocouples for use in oxidizing atmospheres at high temperatures, $R$ and $D$ No. 20, 62 (April).

Bostwick, W.E., Some experiences with noblemetal, metal-sheathed thermocouples, U.S. At. Energy Comm. Rept. UCRL-7361 IMay 10, 19631 .

Bragin, B.K., G.B. Lapp, and I.R. Lepin, Effect of annealing on the thermal electromotive force of platinum-rhodium thermocouples, Tr. Inst. Kom. Standartov, Mer. i l zmerit. Priborov pri Sov. Min. SSSR $1963(71), 220$.

Bull is, L.H., Vacuum-deposited th in $f i l m$ thermocouples for accurate measurement of substrate surface temperature, J.Sci. Instr. 40, 592 (Dec.).

Chambers, J.T., D.L. Rail, and W.H. Geidt, Experimental evaluation of a dual-element transducer for high temperature gas measurements, Aeron. Res. Labs. Office of Aerospace Res., U.S. Air Force Rept. ARL 63-58; AD-409816.

Cox, J.E., High vacuum thermocouple, Rev. Sci. Instr. 34, 931 (Aug.).

Danishevskii, $\overline{S . K} .$, et al, Tungsten-rhenium alloy thermocouples for the measurement of temperatures up to $2500^{\circ}$, Zavosk. Lab. 29, 1139 .

Deni idenko, I.I., N.J. Mitina, and V.G. Padalka, Investigation of plasmoids by means of a thermocouple, Ukrain. Fiz. Zh. 7, 61 ( Jan.).

de Sigoyer, B.B., F. Jaques, and P. Thome, Zircalloy sheathed fuel element rods fitted with thermocouples, U.S. At. Energy 
Comm. Rept. CEA-2290.

Dougherty, L.W., Thermocouple hot-junction mounting techniques, Tech. Memo. SL-M-15; AD- 290914.

Efremova, R.1., et al, Temperature measurements by means of copper-constantan thermocouples, Measurement Techniques No. 3, 214 (Sept.).

Gross, J., and C.B. Griffith, A thermocouple for molten steel, Metal Progr. 83, 106 (June).

Hahnemann, H.W., Thermoelements for measuring gas temperatures up to $2000^{\circ} \mathrm{C}$, Forsh. Geb. Ingen-Wes. 29, 203.

Ham, A.C., and R.E. Jones, Some measurements on thermocouples subjected to radiation, Royal Aircraft Establishment, Farnborough, England, RAE-TN-STRUCT- 343 (Oct. 1963); AD-433036; N65-25351.

Hick, E.W., The requirements for a direct reading $5000^{\circ} \mathrm{F}$ Thermocouple, Proc. InStr. Soc. Am. 18, Paper No. 29.2.63.

Hughes, P.C., and N.A. Burley, Metallurgical factors affecting stability of nickel-base thermocouples, J. Inst. Metals $91,373$.

Janeschitz-Kriegel, H., et al, A temperature probe for flowing polymer melts, J. Sci. Instr. 40, 415 (Aug.).

Koslapov, V., and Yu. M. Skvortsov, Thermocouple needle, Ind. Lab. 28, 1474 ( July).

Krysiak, K.F., et al, A thermocouple suitable for use from 2500 to $4500^{\circ} \mathrm{F}$ on aerospace vehicles, ASD-TDR-63-592; AD414562.

Kuh Iman, W.C., Research and evaluation of materials for thermocouple application suitable for temperature measurements up to $4500^{\circ} \mathrm{F}$ on the surface of guide reentry vehicles, Wright Patterson AFB, Ohio, ASD-TDR-63-233; AD-404577.

Lakh, V.I., B.I. Stadnyk, and Yu.B. Kuzma, Thermoelectric stability of thermocouples made of tungsten-rhenium alloys at high temperature, High Temperature 1 , 267 (sept.oct.).

Ling, F.F., and T.E. Simkins, Measurement of pointwise juncture condition of temperature at the interface of two bodies in sliding contact, Trans. ASME $(\mathrm{J}$. Basic Eng.l 850, 481.

Loskutov, V. 1, New method of measuring the temperature of molten steel, Instr. Construct. No. 11,9 (Nov.).

Lyusternik, V.E., Reproducibility of the calibration of platinum vs platinum rhodium thermocouples over a wide temperature range, High Temperature 1, 120 ( July-Aug.).

Moeller, C.E., Special surface thermocouples, Instr. Control Systems 36, 97 (May).

Moen, W.K., Use thermocouples $r$ ight and melt away weight, Abstract: S.A.E. J. 71, 58 (Nov.).

Morrison, R.D., and R.R. Lachenmayer, Thin $\mathrm{f}$ ilm thermocouples for substrate temperature measurement, Rev. Sci. Instr. 34, 106 (Jan.).

Nanigan, J., Thermal properties of ther- mocouples, Instr. Control Systems 36 ,

87 (Oct.).

Nanigan, J., Matching TC well material to wall improves accuracy, ISA J.10, 75 (Feb).

oetken, E.R., Evaluation of surface attached thermocouples during forced convection heat transfer, U.S. At. Energy Comm. Rept. IDO-16889.

Panasyuk, A.D., and G.V. Samsonov, Thermocouples with electrodes of refractory carbides for use up to $3000^{\circ} \mathrm{C}$, High Temperature 1,116 ( July-Aug.).

Pokhodnya, T.K., and I.I. Fruman, The temperature of a weld pool, AD-400930.

Rainy, W.T. Jr., and R.L. Bennett, Stability of base metal thermocouples in helium atmospheres, ISA Trans.2, 34 (Jan.).

Reichardt, F.A., Measuremeñt of high temperatures under irradiation conditions, Platinum Metals Rev. 7, 122 (Oct.).

SabadeII, A.J., and J. Wenograd, The measurement of the temperature profiles of burning solid propellant by microthermocouples, Princeton U., Guggenhe im Labs. Aeronaut. Eng. Rept. 664; AD-422387.

Schmidt, A.J., A hall generator arrangement for the measurement of small temperature differences in metals, $Z$. Naturforsch 18a, 37 ( Jan.).

schweyher, K., Temperature measurement and heat distribution during heat treatment in an electrically heated experimental furnace, Stahl u Eisen 83, 1162 (Sept. 12)

Sharp, J.D., Rapid immersion pyrometry with expendable couples, Iron and Steel 36, 320 (June).

Sharp, J.D., Expendable-Tip thermocouples, Metal Ind. $102,556$.

Sharp, J.D., Continuous temperature measurement of molten steel, Platinum Metals Rev. 7, 90 (July); J. Metals 15, 902 (Dec.

Skoglund, V.J., and D.M. Yano, The development of a temperature probe and temperature survey of the interaction of an ob1 ique shock wave and a turbulent boundary layer, U.S. At. Energy Comm. Rept. SC-DC3565 (Oct.).

Stamper, J.A., Differential sensing controlled thermocouple, Rev. Sci. Instr. 34, 444 (April).

Stevenson, J.A., Temperature measurement with the expendable immersion thermocouple, Platinum Metals Rev. 7, 2 (Jan.).

Thomas, D.B., Studies on the tungsten-rhenium thermocouple to $2000^{\circ} \mathrm{C}$, J. Res. Nat' I Bur. Std. (U.S.) 67C, 337 (Oct.).

vanvor, H., Special problems in the use of thermocouples for the measurement of temperatures above $1500^{\circ} \mathrm{C}$, Ber. Dtsch. Keram. Ges. 40, 615 .

Vlasov, $V . v .$, Results of testing batteries of differential thermocouples, Instr. Construct. No. 4, 28 (April).

Wechter, G.H., The accuracy of thermocouples in measuring surface temperatures of stainless steel specimens subjected to radiant heat, Aeronaut. Structures Lab., Naval Air and Engineering Center, Phila., Pa., Rept. NAES ASL13R360FR101 (july 10); $A D-412317$. 
Weissenberger, E.G., Metal sheathed thermocouples, Instr. Control Systems 36, 109 (May).

Wormser, A.F., and R.A. Pfuntner, Pulse thermocouple measures at $5700^{\circ} \mathrm{F}$, Space/ Aeronautics $40,116(\mathrm{Ju} / \mathrm{y})$.

Zysk, E.D., D. $\bar{A}$. Toenshof $f$, and $J$. Penton, Tungsten $3 \%$ rhenium vs tungsten $25 \%$ rhenium, a new high temperature thermocouple, Enge Ihard Inds. Tech. Bull. 3, 130 (Mar.).

Gold thermocouples in cryogenic investigations, Design Electron. 1,9 (oct.). Improved thermocouple techniques for safe operation of modern boilers, Power 107, 54 (Jan.).

More on welding thermocouples, ISA J. 10, 76 (April).

Pyrometer for moving surfaces, Mech. Eng. 85, 76 (May).

Surface temperature measurements with thermoelectric materials, AD-286098.

Unusual thermocouples and accessories, Instr. Control Systems 36, 91 (May)

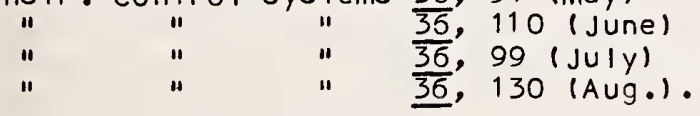

1964

Adsitt, C.L., Minimization of carbon deposit grounding effects on thermocouple me asurements, $A D-448821$.

Allen, J.G., and C.D. Pears, Evaluation of the performance of tungsten-tungsten 26 rhenium thermocouples to about $5000^{\circ}$ F, NASA Rept. CR-55626; N64-16269.

Alvermann, $W .$, and $P$. Stottmann, Temperature measurements in combustion gases by means of thermocouples, N65-16643.

Beck, J.V., Correction of transient thermocouple temperature measurements in heat-conducting solids, AD-445633.

Bennett, R.L. et al, Stability of thermoelectric materials in a helium-graphite environment, U.S. At. Energy Comm. Rept. ORNL - TM- 746.

Berman, R., J.C.F. Brock, and D.J. Huntley, Properties of gold +0.03 percent (At.) iron thermoelements between 1 and $300^{\circ} \mathrm{K}$ and behaviour in a magnetic field, Cryogenics 4,233 (Aug.).

Bradfield, W.. ., A.R. Hanson, and J.J. Sheppard Jr., Design, calibration, and application of a miniature total temperature probe, Trans. ASME $1 \mathrm{~J}$. Heat Transfer) 86, 462 (Aug.).

Bragin, B.K., and R.N. Tetyueva, Thermoelectric uniformity of Chromel, Copel, Alumel and copper wire at low temperatures, Measurement Techniques No.6, 498 (Dec.).

Byrne, M.F., Thermocouple introduced into vessel under pressure, Chem. Eng. 71, 154 (Nov. 23).

Carlson, A.V., Radiation compensating thermocouple temperature sensors, intern. Convention on Military Electronics, 8th., Wash., D.C., Sept. 14-16, 1964 Conference Proc, p. 171.

Chevallier, J.P., Transitory response of thermal receptors utilizing thermocouples, France, O.N.E.R.A. TP-157.

Clark, R.3., Calibration and stability of W/W Re thermocouples to $2760^{\circ} \mathrm{C}\left(5000^{\circ} \mathrm{F}\right)$, Proc. Instr. Soc. Am. 19, Paper No. 16, (Nov.4).

Collins, C.G., organic, structural and control materials, U.S. At. Energy Comm. Rept. APEX-917.

Cookson, R.A., P.G. Dunham, and J.K. Kilham, Non-catalytic coatings for thermocouples, Combust. Flame 8, 168 (June).

Crisp, R.S., and $\bar{W} . G$. Henry, The design of a low temperature thermocouple material, Cryogenics 4, 361 (Dec.); AD-614881.

Czohara, E.A., Res istance welding of strain gages and surface thermocouples, $A D-448$ 518 .

Dalle Donne, M., Tests and data concerning Platinel, a new high temperature thermocouple, Engelhard Inds. Tech. Bull. 5,5 (June).

Danburg, J.E., The equilibrium temperature probe. A device for measuring temperatures in hypersonic boundary layers, Naval Ordnance Lab., White Oak, Md. TR612; AD- 439624 .

Danishevski i, S.K., et al, Thermocouples made of tungsten alloys with rhenium for measuring temperatures up to $2500^{\circ} \mathrm{C}$, Ind. Lab. 29, 1242 (Mar.).

Dinian, J., Thermocouples, CEA-Bib-34; NSA N-18132.

Dow, M.B., Comparison of measurements of interval temperatures in ablation materials by various thermocouple configurations, NASA Tech. Note D-2165 (Nov.).

Dunbar, W.G., High temperature effects on ceramic insulated thermocouple wires, Trans. Inst. Elect. Electron. Engrs. AS-2, 452 (April).

Fricke, H.W., Miniature encased thermocouple for the highest mechanical efficiency, Rigelungstech. Praxis $6,173$.

Furey, M.J., Surface temperatures in sliding contact, Trans. Am. Soc. Lubrication Engrs. 7, 133 (April).

Gaevski, M.M., Errors in dynamic calibration of thermoelectric transducers with differences between their thermal inertias, Measurement Techniques No. 8, $666(\mathrm{Feb}$.$) .$

Gelb, G.H., B.D. Marcus, and D. Oropkin, Manufacture of $f$ ine wire thermocouple probes, Rev. Sci. Instr. 35, 80 (Jan.).

Gross, P.M., et al, A re-entry thermocouple for use up to $4500^{\circ} \mathrm{F}$, ISA Trans. 3, 305.

Heitzman, W.P., Dual- thermocouple Femperature controls, Instr. Control Systems 37 . 109 (May).

Hensel, R., and M. Gohler, Tests with a tungsten/molybdenum immersion thermocouple for measuring the temperature of steel melts, Neue Hutte 9, 237 (April).

Hicks, E.W, Investigātion of tungsten vs tungsten-26 percet rhenium thermocouples above $3500^{\circ} \mathrm{F}$ in oxidizing environments, Proc. Instr. Soc. Am. 19, Paper No. 16 (oct. 3).

Hurst, N.J., Effect of thermocouple size and installation on temperature readings, Army Missile Command, Huntsville, Ala. 
RS-TM-64-1; AD-612493; N65-20521.

Irvine, F.H., J.Picken, and G.H. Greenwood, Measurements of the response of various thermocouple arrangements, Royal Aircraft Establishment, Farnborough, England, RAE-TN-AERO-2959 (Apri I): N65-20514.

Jensen, J.T., J. Klebanoff, and G.A. Haas, Thermocouple errors using $\mathrm{Pt}-\mathrm{P}+(\mathrm{Rh})$ thermocouples on $\mathrm{Ni}$ surfaces, Rev. Sci. Instr. 35, 1717 (Jec.).

Klein, C. $\bar{A} \cdot$, and M.P. Lepie, Operational performance characteristics of pyrolytic graphite thermocouples, Solid State Electronics 7, 241 (April).

Klein, C.A. et ${ }^{-}$al, Development of an ultra high temperature pyrolytic graphite thermocouple, ASD-TDR-63-844; AD-431203; N64-16594.

Kornilov, V.V., and B.l. Makarov, Measurement of rapidly changing temperatures of conducting solid bodies by means of thermocouples, Measurement Techniques No. 10,849 (Mar.).

Kovacs, A., and R.B. Mesler, Making and testing small surface thermocouples for fast response, Rev. Sci. Instr. 35, 485 (April).

Lagedrost, J.F., Laboratory studies toward improvement of high-temperature thermocouples, U.S. At. Energy Comm. Rept. TID 7697 .

Lapp, G.B., and D.L. Popova, Certain thermometric properties of tungsten-rhenium thermoelectrodes, Measurement Techniques No. 11, 917 (April).

Leto, F., Source approval for thermocouple specification, NA5-2722, NA5-27230, NA5-27256, NA5-27290, NA5-27334, NA527340, and NA5-27344, Rocketdyne, Canoga Park, Calif. Rept. No. E-438-40; AD470412 .

Lorch, H.R., Mineral insulated thermocouples, Euronuclear 1, 42 (Sept.).

McCausey, R.J., and E.R. Funk, A high accuracy primary-element-system for temperature measurements in turbine performance tests, Proc. Instr. Soc. Am. 19, Paper No. 15 (Jan. 1).

Markovskii, E.A., and M.M. Krasnoshchekov, Measurement of the temperature of friction surfaces of parts by means of a junctionless thermocouple, Ind. Lab. 29, 1203 (Mar.).

Middlehurst, j. et al, Electrochemical effects in thermocouples, J.Sci. Instr. 41,676 (Nov.).

Moen, W.K., Spacecraft thermocouple installation design, Proc. Instr. Soc. Am. 19, Paper No. 16 (oct. 2).

Moran, J., Molten metal temperature measurement by expendable thermocouples, I nstr. Pract. 18, 1033 (oct.).

Mulcahy, E.L., A Ftachment techniques for the "C" section tests in the space environment simulator, AD-439157.

Nanigan, J., Temperature measurements in the $3000^{\circ} \mathrm{F}$ to $5000^{\circ} \mathrm{F}$ range using ribbon thermocouples, ISA Annual Conference, 19 th New York, N.Y., (Oct. 19).

Palmer, E.P., and G.H. Turner, Response of a thermocouple junction to shock waves in copper, J.Appl. Phys. 35, 3055 (oct.) Pletenetskii, G.E., Thermocouple for measuring high temperatures in vacuum and helium, Ind. Lab. 30, 786 (Dec.).

Pletenetskii, G.E., and A.T. Mandrich, Test ing of thermoelectrode metals in helium at $1500^{\circ}$, Zavosk. Lab. 30, 1243.

Raag, V., Silicon-germanium thermocouple development, N64-17386.

Ramachandran, S., and T.R. Acre, Measuring molten steel temperatures, ISA J.11, 54 (Mar.).

Robinson, J.E., Thermoelectric junctioning project, $A D-430243$.

Rosenbaum, R.L., R.R. Oder, and R.B. Goldner, Low temperature thermoelectric power of gold-iron vs copper thermocouples, Cryogenics 4,333 (Oct.).

Sabadell, A.J., J. Wenograd, and M. Summer$f i e l d$, The measurement of temperature profiles through solid propellant flames using fine theemoocooouples, N64-14547.

Sarychev, G.S., I.M. Veselnitski i, and G.N. Rokhlin, New technique for fixing surface thermocouples, Measurement Technique No. 9, 753 (Feb.).

Semkina, N.V., N.M. Permikina, and T.N. Kodryartseva, Corundum heat-resistant shields for immersion thermocouples, $\mathrm{Tr}$. vost. Inst. ogneuporov $5,49$.

Stadnyk, B.I., and G.V. Samsonov, Thermocouples for measuring high temperatures, High Temperature 2,573 (July-Aug.).

Thomson, A., The thermal response time of sheathed mineral-insulated thermocouples, U.S. At. Energy Comm. Rept. 658 (R).

Truchasson, C., Making very fine heat probe for the measurement of temperatures in water, J. Phys. (France) 25 Supplement NC; 3, 17A (Nar.).

Turner, R.C., and G.D. Gordon, Thermocouple for vacuum tests minimizes errors, Spacel Aeronautics 41, 256 ( Jan.).

Vickers, P.T., Proper probes keep thermocouples reading true, S.A.E. J. 72, 54 (Dec.).

Vidadi, Yu.A., Thermocouple with a compen sating heater, Pribory Tekh. Eksper. IUSSF No. 6, 152 (Nov.-Dec.); Instr. Exp. Tech. No. 6, 1301 (May 1965).

Wormser, A.F., and R.A. Pfuntner, Pulse technique extends range of Chromel-Alumel to $7000^{\circ} \mathrm{F}, \mathrm{instr}$. Control Systems 37, 101 (May) :

Continuous immersion thermocouple aids blas furnace control, Iron \& Steel Eng. 41, 1; ( Ju|y).

\section{5}

Alvermann, $W_{0}$, and $P$. Stottmann, Temperatur measurements with thermocouples in combus tion gases, NASA-TT-F-9537; N65-33954.

Bailey, H.T., Procedure is simple for makir thermocouples, Foundry 93, 226 (May).

Brooks, E.J., and E.W. O'Neal, Keep your thermocouple leads dry, ISA J. 12, 94lMar

Cheesewright, R., A technique for strippins small diameter metal sheathed thermocoupl wire, J.Sci. Instr. 42, 815 (Nov.). 
Chichinadze, A.V., E.D. Braun, and A.G. Abukumkin, Thermocouples for the investigation of materials in friction, Ind. Lab. 31; 928 (June).

Cooper, M.G., and A.J.P. Lloyd, Miniature thin film thermometers with rapid response, J. Sci. Instr. 42, 791 (Nov.).

Daniells, G.E., Measurement of gas temperature and the radiation compensating thermocouple, Inst. of Environmental Sci. Annual Tech. Meeting, 11 th, Chicago, I11., April 21-23, 1965 Proc. A6529982 19-11.

Devita, V.A., Predicting cryogenic thermocouple time constant, Control Eng. 12, 63 (July).

Fanciullo, S., Drift and endurance testing of Chromel/Alume I, W- $5 \mathrm{Re} / \mathrm{W}-26 \mathrm{Re}$ and Mo/W-26 Re thermocouples at 1950$2000^{\circ} \mathrm{F}$ for 10,000 hours, U.S. At . Energy Comm. Rept. PWAC-454; N65-17407.

Finnemore, D.K., J.E. Ostenson, and T.F. Stromberg, Secondary thermometer for the 4 to $20^{\circ} \mathrm{K}$ range, Rev. Sci. Instr. 36 , 1369 (Sept.)

Finnemore, D.K., et al, AuFe vs Cu Thermocouples, N65-13852.

Genet, F., and B. Milloit, Mesure du temps de remataux de thermocouples dans les dircuits de metaux liquides, European Atomic Energy Community, Ispara, I taly EUR-2281. F; NSA 19-22659.

Gordov, A.N., et al, An experimental investigation of the inertia of microthermocouples, High Temperature $\underline{3}, 268$ (Mar.-April).

Farrow, R.L., and A.P. Levitt, Tungsten/ tungsten-rhenium thermocouples in a carbon atmosphere, Army Materials, Research Agency, Watertown, Mass., Materials Eng. Div. Rept. AMRA-TR-64-12, July 1964; $A D-606565 ; N 65-10886$.

Hall, B.F. Jr., and N.F. Spooner, Study of high temperature thermocouples ( $\mathrm{Fi}$ nal Rept.) AFCRL-65-251; AD-619038; N65-36842.

Hanneman, R.E., and H.M. Strong, Pressure dependence on the emf of thermocouples to $1300^{\circ} \mathrm{C}$ and $50 \mathrm{~K}$ bar, J. Appl. Phys. 36, 523 (Feb.); ASME Preprint No. 64$\overline{W A} / P T-21$ (Dec. 1964).

Hendricks, J.W., and D.L. MCE Iroy, High temperature high vacuum thermocouple drift, Oak Ridge Nat1. Lab., Tenn. ORNLP-1069; NSA 19-20278.

Kamenetskii, A.B., and N.V. Gul'ko, Interaction of thermal electrodes in tungsten-rhenium thermocouples with pure oxides insulation, Measurement Techniques No.6, 506 (June).

Kisliy, P.S., and M.A. Kuzenkova, Gas impervious protective coatings for thermocouples made of zirconium boride Poroshkovaya Met., Akad. Nauk Ukr. SSR No. 1, 32; Rev. Metal Lit. 22, No. 5 (May 1965).

Klapper, J.A., et al, High temperature corrosion of constantan thermocouple conductors, Mater. Protect 4, 72 .

Kocho, V.S., et al, operation of thermocouple tips made from zirconium boride in the Bessemer convertor, Poroshkovaya Met., No. 3, 88.

Makarov, B.l., Errors in temperature measurement on the surface of a solid body using a thermocouple when heating and cooling follow an arbitary law, NASA-TTF-9496; N65-29736.

Matthew, H.L., Thermocouple calibration in subsonic air flow, Wyoming Univ., Laramie Masters Thesis AD-617305; N65-31753.

McCoy, H.E. Jr., Influence of $\mathrm{CO}_{-} \mathrm{CO}_{2}$ environments on the calibration of Chromel P-Alumel thermocouples, Oak Ridge Nat 1. Lab., Tenn. ORNL-P-1070; NSA 19-22664. Novak, P.E., and R.R. Asamoto, Evaluation of thermocouples for use to $2600^{\circ} \mathrm{C}$ in mixed-oxide fuel, Trans. Am. Nucl. Soc. 8,388 ( Nov.).

Pak, V., and Yu.P. Krinskii, Thermoelectric method for measuring the mean temperature of metallic specimens, Ind. Lab. 30, 1033 (Feb.).

Phillips, L.S., The Measurement of thermoelectric properties at high temperatures, J. Sci. Instr. 42, 209 (April).

Pinchevskii, A.D., Transfer functions for commercial thermoelements, Measurement Techniques No. 5, 416 (May).

Rollinger, C.N., Convectively cooled thermoelements with variable cross sectional area, J. Heat Transfer 87, 259.

Sabadell, A.J., et al, Measurement of temperature profiles through solid propellant flames using $f$ ine thermocouples, AlAA $J$. 3, 1580 (sept.).

SaTzano, F.J., Stability of a rhenium-graphite thermocouple, U.S. At. Energy Comm. Rept. BNL-8812.

Samsonov, G.V., and P.S. Kislyi, Protective sheaths of thermocouples for the continuous control of the temperature of molten metals, ogneupory No. 4, 28.

Smith, R.R. Jr., High temperature thermocouple research and development program, NASA-CR-67348; N65-35412.

Appendix 1: Drawings and design notes NASACR-67196, T-1097; N65-35416.

Appendix 2: Calibrations NASA-CR-67197, T-1097; N65-35415.

Appendix 3: Miscel laneous technical data NASA-CR-67347, T-1097; N65-35358.

Appendix 4: New technology NASA-CR-67195, T-1097; N65-34904.

Sparks, L.L., and R.L. Powell, Available low temperature thermocouple information and services, Natl. Bur. Std., Boulder, Colo., NASA-CR-63149; NBS-8750; N65-25244.

Studennikov, Yu. A., and G.E. Erkovich, Compensation wires for VR5/20 thermocouples (exchange of experience) Ind. Lab. 31,469 (Mar.).

Svede-Shvets, N.l., et al, Thermoelectric characteristics of metallic sintered alloys on a tungsten and molybdenum base, FTD-TT-65-642; AD-619334; NSA 19-47019.

Tallman, C.R., Analytical model for study of thermocouple error attributed to electrical conduction in insulation, Los Alamos Scientific Lab., Univ. of Calif., (N. Mex.). Contract W-7405-eng-36.

Thomson, A., The thermal response time of 
sheathed mineral-insulated thermocouples, Trans. Soc. Instr. Technol. 17, 49 (June).

Tschang, P.S., Temperature determination in moderately dense, high-temperature gases by transient thermocouple probes, Columbia Univ., New York ARL-65-95; AD-617702; N65-30297.

Ubbelohde, A.R., The anisotropy of graphite, Endeavour 24, 63 (May).

van Drasek, J.J., and B.A. Short, Conversion formulas for copper-constantan thermocouples, Instr. Control Systems 38,106 (Feb.).

waTker, B.E., C.T. Ewing, and R.R. Miller, Instability of refractory metal thermocouples, Rev. Sci. Instr. 36, 816; NRL$6231 ; A D-621484$.

Walker, B.E., et al, study of the instability of noble metals in vacuum, Rev. Sci. Instr. 36, 601 (May); NRL-6236; $A D-620322$; N $\overline{65}-36740$.

Yak imov, A.V., V.A. Sipailov, and Yu. A. Kazimirchik, Thermocouple calibration for temperature measurements in the grinding zone, Ind. Lab. 31, 1018 (July)

Zabawsky, Z., and F.M. Gavan, Thermocouples and their usage in ASTM standards, Mater. Res. Std. 5, 80 (Feb.).

Zenin, A.A., On hea $\bar{f}$ exchange of microthermocouples under conditions of combustion of condensed substances, N6530419 .

Zuikov, N.V., et al, A thermocouple for measuring temperature up to $2500^{\circ} \mathrm{K}$, Teplofizika Vysokikh Temperatur 3, 815 (Sept.) Russian.

A rhodium-platinum thermocouple for $h i g h$ temperatures, Platinum Metals Rev. 9, 9 ( Jan.)

Evaluation of the pperformance of seven refractory metal thermocouples ( $F$ inal Rept.) Southern Research Inst., Birmingham, Ala. NASA-CR-63809; N65-28366.

\section{RESISTANCE DEVICES}

1958

de Vroomen, A.R., Practical interpolation procedure for carbon thermometry between 1.5 and $30^{\circ} \mathrm{K}$, Probl. Low Temp. Phys. Thermodyn., Proc. Meeting Comm. I, Intern. Inst. Refrig., Delft, Neth., p. 137 .

Sachse, H.B., Thermistors as sensing elements for low temperatures, Probl. Low Temp. Phys. Thermodyn., Proc. Meeting Comm. I, Intern. Inst. Refrig., Delft, Neth., p. 154.

van Dijk, H., Platinum resistance thermometers between 90 and $4^{\circ} \mathrm{K}$, Probl. Low Temp. Phys. Thermodyn., Proc. Meeting Comm. I, Intern. Inst. Refrig., Delft, Neth., p. 155 .

1960

Yaryshev, N.A., and A.S. Makhnovetski on the errors occurring in the measurement of non stationary surface tempera- tures, Priborostroenie 3, No. 6, 100.

1961

Somers, L.M., The variation of $\left(K_{p} c_{p}\right)^{\frac{1}{2}}$ with temperature in 'Pyrex', Cornell PAeronaut. Lab., Buffalo, N.Y. Rept. CAL-106; AD279897; N65-10672.

\section{2}

Alieva, T.Z., and V.P. Chekulaev, Design characteristics of resistance thermometers, Tr. Inst. Kom. Standartov, Mer i Izmerit., Priborov Pri Sov. Min. SSSR 1962 No. 63, 218 .

Cherepin, V.T., Measurement of temperatures at high rates of heating and cooling, Ind. Lab. 28, 211 (Aug.).

Corruccini, R.J., Cryogenic temperature measurement with platinum res istance thermometers- is fixed-point calibration adequate, Proc. Instr. Soc. Am. 8, 139.

Golovashkin, A.I., and G.P. Motülevich, A sensitive low-inertia thermal resistor for helium temperatures, Instr. Exp. Tech. No. 2, 404 (Nov.).

Gunbin, B.L., Instrument for remote measurement of temperature of moving media, Measurement Techniques No.4, 288 (Sept.).

La Fond, E.C., The Usnel thermistor chain, Navy Electronics Lab., San Diego, Calif. Rept. No. NEL-1114; AD-471158.

MCAllan, J.V., Comparison of resistance thermometers used to measure freezing points of metals, Comite Consultatif Thermometrie, Comite Intern. Poids Mesures, $6 e$, Sevres, France 1962 p.52.

Mikhailov, N.N., and A. Ya. Govor, Lead brass resistance thermometers for low temperature measurement, Pribory i Tekh. Eksper. 1962, 180 (Mar. - April).

Raymond $J \cdot \overline{R .,} A$ well water tempetature lagging system, U.S. At. Energy Comm. Rept. HW- 73994 .

Riddle, J.L., Constant of the interpolation formula for platinum resistance thermometers, Comite Consultatif Thermometrie, Comite Intern. Poids Mesures, 6e, Sevres, France 1962, 198.

Sokolov, YU.E., Miniature copper resistance thermometer with an unbalanced bridge, Measurement Techniques No.2, 126 (July).

\section{3}

Abichandani, C.T., P.T. Bhatt, and E.N. $B l a g o v e s c h e n s k i$, Wire resistance thermometers for determining soil temperatures, Res. Ind. (New Delhi) 8, 257.

Adirovich, E.I., S.P. Luñezhev, and E.I. Chernomorskaya, Application of thermistors to cryoscopic measurements, Dokl. Akad. Nauk UZ. SSR 20, No. 9, 18 .

Andirch, E., and T. Van der Sterre, Structure and properties of thermistors, Elektron. Rundschau 17, 63 (Feb.).

Alieva, F.Z., Cali bration of platinum resistance thermometers at two points, Measurement Techniques No. 11, 931 (June).

Alieva, F.Z., Measuring temperature in 
the -182.97 to $+630^{\circ}$ range with a platinum resistance thermometer calibrated at two points, Tr. Inst. Kom. Standartov, Mer i lzmerit. Priborov pri Sov. Min. SSSR 1963 No. 71,134 .

Barber, C.R., Low temperature platinum resistance thermometry, Platinum Metals Rev. 7, 15 (Jan.).

Beck, A.E., Lightweight borehole temperature measuring equipment for resistance thermometers, J.Sci. Instr. 40, 452 (Sept.).

Berry, R.J., Relationship between the real and ideal resistivity of platinum, can. J. Phys. 40, 946.

Brodski $i, A \cdot D .$, Measuring low temperatures with a platinum resistance thermometer without calibration at the oxygen boiling point, Tr. Inst. Kom. Standartov Mer i lzmerit. Priborov pri Sov. Min. SSSR 1963 No. $71,149$.

Clark, J.N., J.A. Spahr, and R.A. Hendle, The effect of freezing-thawing cycles on thermistor calibration, PB 162793.

Cook, J.C., and K.E. Kenyon, Fast-response thermistor probes for temperature microstructure studies at sea, Rev. Sci. Instr. 34, 495 (May).

Dunn, W.F., A temperature measuring system using RDF Stilson resistance elements, Allegany Ballistics Lab., Rept. ABLE 87; AD-408503.

Godin, M.C., A modified thermistor thermometer, J. Sci. Instr. 40, 500 (Oct.).

Golovashkin, A.N., and G.P. Motulevich, a sensitive low inertia thermal resistor for helium temperatures, cryogenics $\underline{3}$, 167 (Sept.).

Hinkelmann, H., and H.M. Ihme, An electrical dep-sea thermometer with short adjustment time, $z$. Angew. Phys. 15, 429.

Hoover, H.M., A rapid response high accuracy thermal probe, Marine Sci. Instr. 2,43 .

James, B.W., and B. Yates, Indium resistance thermometery, J.Sci. Instr. 40, 193 (April).

Kalinkina, I.N., Resistance of carbon thermometers as a function of temperature, Instr. Exp. Tech. No. 3, 580 (Nov.)

kaufman, A.B., Bonded-wire temperature sensors, Instr. Control Systems 36, 103 (May).

Knobler, C.M., W.I. Honeywe II, and C.J. Pings, Thermal and hydrostatic behaviour of miniature platinum resistance elements, Rev. Sci. Instr. 34, 1437 (Dec.).

Kozhukh, V. Ya, Selecting the value of a thermistor for remote measurements of temprature, Measurement Techniques No. 6,477 (Nov.).

Mcknight, G.P., Resistors for precise temperature measurements, Electron. Ind. 22, $97(\mathrm{Ju|y})$.

Mikhailov, N.N., and A. Ya. Govor, Leaded brass resistance thermometers for measuring low temperatures, Cryogenics 3 205 (Dec.); Instr. Exp. Tech. No. 2, 402 ( Nov.).

Misek, K., and J. Polak, Measurement of temperature of thin metallic wires, cesk. Casopis Fys. 13, 87 .

Nalle, D.H., Recording small temperature changes, Measurement and Control 2, 363

(Sept.).

or lova, M.P., D.N. Astrov, and L.A. Medvedeva, Indium res istance Thermometers for temperatures in the $3.4-300^{\circ} \mathrm{K}$ range, instr. Exp. Tech. No. 2, 342 (Nov.).

Priestley, P.T., A thermistor thermometer with digital display, J. Sci. Instr. 40, 505 (oct.).

Riddle, J.F., Temperature measurements below $1000^{\circ} \mathrm{K}$, NASA Measurement of Thermal Radiation Properties of Solids $1963 \mathrm{p}$. 11 ; NS4-10939.

Saburi, $0 .$, and $R$. Wakino, Processing techniques and applications of positive temperature coefficient thermistors, IEEE Trans. CP-10, 53 (June).

Sachse, H.B., Measurement of low temperatures with semiconductor resistance thermometers, $Z$. Angew. Phys. 15, 4 (Jan.).

Sapoff, M., and R.N. Oppenhe $\overline{i m}$, Theory and application of self-heated thermistors, Proc. IEEE 51, 1292 (Oct.).

Scagnet $t i, M \cdot \bar{S} \cdot$, and $J$. Crabol, Fast-response platinum film temperature probes, Rech. Aerospatiale No. 97, 23 (Nov.-Dec.).

Scheppner, E., Resistance bulb time constants, AD-409337.

Srivastava, K.C., and J. Singh, Apparatus for measuring temperature in a settling concrete block and controlling it adiabatically, Indian J. Technol. 1, 6 (Jan.).

Terris, 0., Platinum resistance Thermometer circuit with 5 volts output, U.S. At. Energy Comm. Rept. NAA-SR-Memo-8073 I Jan. 15); NSA N-20283.

vakalov, I.A., Influence of ultra-sound on electrical conductivity of thermoresistors, $A D-412211$.

Vanik, M.C. et al, Reproducible thermistor refinement program, AD-407792.

Voronel, A.V., and V.V. Shchekochikhina, Miniature platinum resistance thermometer, Instr. Exp. Tech. No. 2, 364 (Nov.).

Wienke, H.J., P.S. Myers, and O.A. Uyehara, A resistance thermometer for engine compression temperatures, S.A.E. J. 71, 104 (july).

Corrections for use in low temperature platinum resistance thermometry, Natl. Bur. Std. (U.S.) Tech. News Bull.47, 101 ( June).

Wafer thermistors provide the route to high precision in resistor manufacture, $R$ \& $D$ No. 19, 51 (Mar.).

\section{4}

Alieva, F.Z., A method of measurng temperature with a platinum resistance thermometer, Air Force Systems Command, Wright Patterson AFB, Ohio, Foreign Technology Division FTD-TT-64-83/1\&4; AD-601561; N64-25451.

Alieva, F.Z., New platinum resistance thermometer for precision measurements of $\mathrm{high}$ temperatures, Measurement Techniques No. 6,487 (Dec.). 
Ambrok, G.S., Method of calibrating thermal flow detectors, Measurement Techniques No. 11,918 (April).

Barber, C.R., International Comparison of platinum resistance thermometers $\$ 167$, R13 and $N 109$ in ten laboratories (Measurement of the interval $0-100^{\circ}$ of the practical international scale of temperaturel, Comite Consultatif Thermometrie Comite Intern. Poids Mesures, 6e, Sevres, France 1962, 64 (Publ. 1964).

Bardila, P.l. etal, New platinum resistance thermometer, Measurement Techniques No. 5, 389 (Nov.).

Batha, H.D., and P.E. Carroll, Unicrystalline silicon carbide thermistor, IEEE Trans. CP-11, 129 (June).

Berry, R.J., Choice of resistance thermometer for the region $10-90^{\circ} \mathrm{K}$, Comite Consultatif Thermometrie, Comite Intern. Poids Mesures, 6e, Sevres, France 1962, 125 (Publ. 1964).

Black, W.C. Jr., et al, Speer Carbon resistors as thermometers for use below $10 \mathrm{~K}$, Rev. Sci. Instr. 35, 587 (May). Boel, M., and B. Erickson, A correlation study of a thermistor thermometer, Polytechnic Inst. of Brooklyn PIBAL-696 (May); AD-601656; N54-30589.

Bogdan, L., High temperature thin film resistance thermometers for heat transfer measurement, NASA Contract Rept. CR-26 (1964); AD-414970; N64-17988.

Bogdan, L., Measurement of radiative heat transfer with thin film resistance thermometers NASA Contract Rept. CR-27(1964).

Bulychev, V.S., Thermistor for temperature meter with stabilized supply, Measurement Techniques No. 8, 673 (Feb.).

Chao, J.L., and V.A. Sandborn, A resistance thermometer for transient temperature measurements, AD-600346.

Chappe II, R.W., and A. Moilliet, A sensitive resistance thermometer with fast response for use in the sea, Pacific Naval Lab., Esquimalt, British Columbia PNL TM64-3 (May 1964); AD- 443817 .

Davis, W.T., Engine temperature indicator, Electronics World 71, 36 (April).

Dupre, A., et al, The use of graphite thermometers in heat conducting experiments below $1{ }^{\circ} \mathrm{K}$, Cryogenics 4 , 354 (Dec.).

El Agib, A.A.R., The pair ratio method of measuring small temperature difference, J. Sci. Instr. 41, 592 (oct.).

Evans, J.P., and G.W. Burns, Stability of a platinum resistance thermometer at high temperatures, Comite Consultatif Thermometrie, Comite Intern. Poids Mesures, 6e, Sevres, France 1962, (Publ. $1954)$.

Fluke, G.L., Winsco platinum resistance temperature transducer-Model 2610-2, AD439778.

Goldwater, F.J., Linearization of resistance thermometer output, J.Sci. Instr. 41,46 (jan.).

Hartunian, R.A., and R.L. Varwig, A correction to thin-film heat transfer measurements, AD- 605036 .
Jessop, A.M., A lead compensated thermistor probe, J. Sci. Instr. 41, 503 (Aug.).

Kaganov, M.A., Precision of differential thermistor measuring circuits, Measurement Techniques No. 3, 231 (Oct.).

Kaganov, M.G., and I.S. Lisker, Inertia of electric resistance thermometers, Inzh. Fiz. Zh. 7, 28 (April).

Kalinkina, T.N., Temperature dependence of the resistance of carbon thermometers, Cryogenics 4,327 (oct.).

Karbe, Yu.V., Semiconductor surface thermometer, instr. Construct No. 7, 27 (July).

Kirsa, V.l., Method of selecting identical semiconductor thermistors from a batch, Instr. Construct. No. 5, 26 (May).

Kozhukh, V. Ya., The accuracy of temperature measurement with semiconductor resistors, Instr. Construct. No. 3, 10 (Mar.).

LaForce, R.C., S.F. Ravitz, and W.B. Kendall, Device for the precise measurement of small temperature changes, Rev. Sci. Instr. 35, 729 (June).

Langlands, R.C., A stable copper resistance thermometer for field use, J.Sci. Instr. $41,478(\mathrm{Ju} \mid \mathrm{y})$.

London, G.E., An apparatus for measuring rapidly changing temperatures, WrightPatterson AFB, Ohio, FTD-TT-64-82/1,2\&4; $A D-601508$.

Manche, E.P., and B. Carroll, Temperature measurement in thermogravimetry, Rev. Sci. Instr. 35, 1486 (Nov.).

Meservey, R.H., Fuel plateresistance thermometer, U.S. At. Energy Comm. Rept. 100-16965 (March).

Mishchenko, K.P., and V.P. Tungutsov, New method for the calibration of semiconductor resistance thermometers in the determination of the heat capacity of pure I iquids and solutions, Zh. Prikl. Khim. 37,1243 .

Nakaya, S., and H. Uchiyama, Thermometry of high temperatures with the aid of a platinum resistance thermometer, Comite Consultatif Thermometrie, Comite Intern. Poids Mesures, 6e, Sevres, France 1962, 57 (Publ. 1964).

Novopavlovski $i$, V.S., Errors in the measurement of surface temperature with the resistance thermometer, Inzh. -Fiz. Zhur. 7, 52 (May).

oreshkin, P.T. et al, Thermistors for measuring the surface temperatures of bodies, Ind. Lab. 30, 296 (Sept.).

or lova, M.P. et al, Germanium resistance thermometer for low temperatures, Inst. Exp. Tech. No. 1, 253 (Sept.).

Or lova, M.P., D.N. Astrov, and L.A. Medvedeva, Indium res istance thermometer for the temperature range 3.4 to $300^{\circ} \mathrm{K}$, Cryotenics 4, 95 (April).

Pearson, $\bar{P} \cdot H_{1}, A n$ investigation into the response and corrections to a thermistor and a platinum wire resistance thermometer for temperature measurement in the upper a tmosphere, N64-22493.

Quarmby, A., Transient response of wire resistance thermometers, J. Roy. Aeronaut. soc. $68,696(0 c t$.$) .$ 
Ruskin, J.M., Thermistors as temperature transducers, Data Systems Eng. 19, 24 (Feb.).

Seuf, G., Temperature measurement with semiconductor diodes, Exptl. Tech. Physik. 12, 70 .

Stanishevskiy, V.N., Use of thermistors for measurement of temperature, N6515513.

Tebo, A.R., Precise measurement of atmospheric temperatures, Army Signal Res. and Development Agency, Fort Monmouth, N.J., USAELDR-TR-2405; AD-430573; N6420854.

Tsien, H.C., Piston zone temperature measurement, Instr. Control Systems 37, 103 (May).

van Dijk, H., Results obtained from measurements on platinum resistance thermometers at the thermometry section of the Kamerlingh onnes Laboratorium, Leiden, Physica 30, 1498 (Aug.).

vautier, C., and A. Colambani, Thin film platinum resistance thermometers, Compte Rend. 258, 4706.

Zaitsev, A.M., Miniature low-inertia platinum resistance thermometer, Instr. Exp. Tech. No. 1, 250 (Sept.).

Zsombor-Murray, P.J., A heat transfer probe for use in a high temperature gas, $A D-435096$.

Platinum films as temperature probes, Platinum Metals Rev. 8,146 (Oct.).

\section{5}

Boel, M., and B. Erickson, Correlation study of a thermistor thermometer, Rev. Sci. Instr. 36, 904 (July).

Chevako, R.J., Thermistor bibliography, Proc. IEEE 53, 175 (Feb.).

Clark, G.Q., and J.G. McCoy, Upper A tmospheric temperature sensing using the head thermistor, N65-33645.

Coor, T., and L. Szmauz, Digital thermometer, Instr. Control Systems 38, 125 (May).

Cunsolo, S. et al, Interpolation and extrapolation of carbon resistance thermometer calibration data in the liquid helium II region, Cryogenics $\underline{5}, 168$.

George, J.T., and F.D. DeMarco, ML-419 thermistor P.E.M. final engineering report, Jan. 1, 1963-Aug. 31, 1964, Bendix Corp., Baltimore, Md., Friez Instr. Div., AD-608963; N65-26306.

Gerber, R., F. Vilim, and K. Zaveta, Measurement of low temperature with a carbon thermometer, Cesk. Casopis Fys. 15, 340 (czech).

Hales, J.L., and E.F.G. Herington, A new method for the computation of temperature in platinum resistance thermometry, J. Sci. Instr. 42, 203 (April).

Hardy, D., Temperature sensing resistor environment test, Texas instr. Inc. Rept. No. 5849-E; AD-460242.

Janicke, J.M., Direct-reading platinum thermometer, Instr. Control Systems 38 , 129 (May).

Jones, E.W., Calibration techniques for thermistors, Instr. Control systems 38, 123 (may).

Lakh, V.l., and V.A. Kochan, Overheating of $p l a t i n u m$ resistance thermometers by a measuring current, Teplofizika Vysokikh Temperatur 3,661 (July).

Nechaev, G.K., Semiconductor thermistors in automation Wright-Patterson AFB, Ohio, Foreign Tech. Div. Rept. No. FTD-MT-64210; AD-618048; N65-31893.

Or lova, M.P. et al, Germanium resistance thermometer for low temperatures, Cryogenics $\underline{5}, 165$.

Pharo, L.C.C., Some characteristics of the VECO $32 \mathrm{~A} 8$ thermistor operating in a self heated condition, Rev. Sci. Instr. 36, 211 (Feb.).

Priestly, P.T., Multiple thermistor indicator for thermometric analysis, J. Sci. Instr. 42, 35 (Jan.).

Sapoff, M., and R.M. Oppenheim, A blanket approach to a linear thermistor network Part 1. The method, Electron. Design 13, 20 (Mar.).

Sapoff, M., and R.M. Oppenheim, A blanket approach to a linear thermistor network. Part 2. Examples, Electron. Design 13, 32 (April).

Schneider, D.B., The thermistor thermometer, Instr. Control Systems 38, 119 (May).

Seginer, A., A. Cohen, and J. Rom, Calibration of thin $\mathrm{film}$ resistance thermometers for heat flux measurements in a shock tube, Israel J. Tech. 3, 25 (Feb.).

Sychev, V.V., and N.I. Gorbunova, Accuracy of temperature measurement by means of the standard platinum resistance thermometer, Teplofizika Vysokikh Temperatur 3, 632 (July).

Toenshoff, D.A., Bird-cage resistance thermometer, Engelhard Inds. Tech. Bull. 5, 127.

Resistor, Thermal (Thermistor) Kearfo $\bar{\dagger} \dagger$ Div. General Precision Inc., Little Falls, N.J., Rept. No. 603-006; AD-463 509.

Thin film thermistor temperature sensor. Final report, Metrophysics Inc., Santa Barbara, Calif., AD-472737.

\section{Radiation Devices}

\section{0}

Babushkin, V.V., Apparatus for measuring a high-temperature gas stream at high pressure, $\mathrm{Tr}$. Inst. Kom. Standartov Mer i Izmerit. Priborov pri Sov. Min. SSR 42, 26.

\section{1}

Beattie, J.R., Measurement of the temperature of transparent materials, Acta Imeko 4, 210.

\section{2}

Beer, J.M., and I.J. Claus, The "traversing" method of radiation measurement in l uminous flames, J. Inst. Fuel 35, 437.

Burns, E.A., and R.J.P. Lyon, Errors in the measurement of the temperature of the moon, Nature 196, 463 (Nov.).

Casselton, R.E. W. et al, Black-body radiation from partially enclosed cavities, 
J. Inst. Metals $91,408$.

Faizullov, F.S., Pyrometric investigation of the state of air, nitrogen and argon behind a shock wave, Tr. Fiz. Inst., Akad. Nauk SSSR 18, 105.

Grien, H.R., Plasma spectroscopy, Ionization Phenomena in Gases, Vol. 11 , North Holland Publishing Co., Amsterdam (1962) p. 1857.

kean, L., A contribution to the theory of schlieren sensitivity and quantitative evaluation, Aeron. Systems Div., Wrightpatterson AFB, Onio, ASD-TDR-62-924 (Dec.).

Kocho, V.S., V.l.Grankovski i, and V.G. Antosyak, Measurement of gas temperature with a radiation pyrometer, Ind. Lab. 28, 219 (Aug.).

Kroepelin, H., Temperature determination in arcs in hydrocarbon atmospheres, lonization Phenomena in Gases, Vol. II, Nor th-Holland Publ ishing Co., Amsterdam (1962) p. 1830 .

Kudroyavtsev, E.M. et al, Pyrometric investigation of the state of a gas behind a reflected shock wave, Tr. Fiz. Inst., Akad, Nauk SSSR 18, 159.

Lovejoy, D.R., Detection Timits in radiation and optical pyrometer, J. Opt. Soc. Am. 52, 1387 (Dec.).

Maleev, E.M., and D.S. Ermakov, single beam two-frequency pyrometer for measuring flame temperatures, Optics and Spectroscopy 13, 339 (Oct.).

Reeves, E.M., and W.H. Parkinson, Spectral energy distribution and brightness temperatures in continuous flash sources, Ionization Phenomena in Gases, Vol. I, North-Holland Publishing Co., Amsterdam (1962) p. 1017 .

Shaw, V.G., Two color pyrometry in the metals industry, Proc. Instr. Soc. Am. 17, Paper No. 58.3.62.

Smith, W.M.., and J.L. Frank, Low temperature infrared thermometer, Proc. Instr. Soc. Am. 17, Paper No. 21.4.62.

Sobelev, N.N. et al, A spectroscopic investigation of the state of gases behind a shock wave,. Ionization Phenomena in Gases, Vol. II, Nor th-Holland Püblishing Co., Amsterdam (1962) p. 2122.

Volk-Levanovits, M.V., Measurement of temperature of a mercury arc by the method of Bartels, Inzh. Fiz. Zh. 2,87 (Aug.).

\section{3}

Adhav, R.S., and J.G. Kemp, Infrared radiometer, J. Sci. Instr. 40, 26 (Jan.).

Bates, R.L., and W.L. E isenman, Improved black radiation detector, Naval Ordnance Lab., Corona, Calif., NOLC Rept. 594, Photodetector Series 60 (Dec. 15, 1963); $A D-426778$.

Bruckner, R., Spectrometeric measurements of temperatures above $3500^{\circ} \mathrm{C}$ and determination of temperature distribution in a plasma burner at atmospheric pressure, Ber. Dtsch. Keram. Ges. 40, 603.

Casselton, R.E.W., G. Erez, and T.J. Quinn, Black-body radiation from par- tially enclosed cavities, J. Inst. Metals (G.B.) 91 pt 12, 408 (Aug.).

Clark, R.G., Monitoring surface temperatures of irradiated fuel elements, U.S.

At. Energy Comm. Rept. HW-SA-3036 (May 6

Drawin, H.W., Spectroscopic temperature and density measurement of plasmas in the absence of thermodynamic equilibrium, Z. Phys. 172, 429.

Dreyfus, M.G., Spectral variation of blackbody radiation, Appl. Optics 2, 1113 (Nov.

Euser, P., Compensation pyrometer for the measurement of surface temperatures of moving parts independent of the surface emissivity, Instr. Pract. 17, 487 (May).

Fairbairn, A.R., Temperature measurements of $C_{2}$ and $C N$ radicals generated in a shock tube, II Detonation, Proc. Roy. Soc. (London) A276, 513.

Fateeva, N.S. et al, An optical method of determining the melting temperature of graphite as a function of pressure up to 40,000 atm, Soviet Physics-Doklady 8, 904 (Mar.).

Frock, H.N., and W.T. Shreve, A new automatic balancing optical pyrometer, Proc. Instr. Soc. Am. Paper No. 29.5.63.

Gaydon, A.G., I.R. Hurle, and G.H. Kimbell, Temperature measurements of shock waves and detonations by spectrum- line reversal, IV Development of detonation, Proc. Roy. Soc. (London) A273, 241 (May 21).

Gilardini, A., Microwave determination of after glow temperatures and electron col$\mathrm{I}$ ision parameters in nitrogen and oxygen, $A D-418360$.

Golub, L.M., and E.S. Shpigelman, Rationalizing the calibration me thod of referenc telescopic radiation pryometers, Measurement Techniques No. 4, 317 (Oct.).

Gordov, A.N., Noncontact methods of measuring the true temperature of heated bodies High Temperature 1,128 (July-Aug.).

Gordov, A.N., Simplification of the method for calibrating and testing color pyrometers, Measurement Techniques No. 1,41 (Aug.).

Goryachev, B.A., Photoelectric pyrometer, Ind. Lab. 28, 1202 (Nar.).

Greenshields, D.H., Spectrometric measurements of gas temperatures in ac-heated jets and tunnels, NASA Tech. Note D-1960 (Oct.).

loselson, G.L., Methods for automatic compensation of the emission coefficient in measuring the plasma temperature with respect to radio-frequency thermal radiation, High Temperature 1, 391 (Nov.-Dec.).

Kandyba, $v_{. V} .$, Measuremen $\bar{f}$ of temperature in flames, gas flows, and plasmas from spectral line intensities, High Temperature 1, 386 (Nov.-Dec.).

Kelsall, D., An automatic emissivity compensated radiation pyrometer, J. Sci. Instr. 40, 1 ( Jan.).

Kirenkov, T.l., Effective wave length of a photoelectric spectral pyrometer, Measurement Techniques No. 6,474 (Nov.).

Kogan, A.V., A method of reducing the error of a disappearing $\mathrm{f} i$ lament pyrometer, High Temperature, 1, 273 (Sept.-Oct.). 
Kozyrev, B.P., Basic problems of radiation pyrometry of slightly heated or cooled objects, Inzh.-Fiz. Zh. $6,9$.

Kusch, H.J., Development of methods for quantitative spectroscopic temperature determination of plasmas, keel U. Inst. Exp. Phys. N-21786.

Land, T., and R. Barber, Some recent developments in radiation pyrometry, Trans Soc. Instr. Technol. 15, 1 (Mar.).

Lapina, E.A., An infrared pyrometer for the determination of spectral coefficients of black body radiation of some types of oxide cathodes, Tr. Inst. Gos. Kom. Standartov, Mer i Izmeritel'n. Priborov SSSR No. 71, 153.

Lapp, M.., and L.P. Harris, Influence of alkali-vapor a tmospheres on pyrometrically determined temperatures; cesium and potassium, J. Appl. Phys. 34, 3622 (Dec.).

Laughin, R.D., Needle temperature measurement by infrared pyrometry, Textile Res. J. 33,35 ( Jan.).

Lehman, W.J. Jr., Black body radiance-temperature conversion table, Aberdeen Prooving Ground Rept. DPS 1059 (Aug.); $A D-417811$.

Magdeburg, $\dot{H}_{:}$, The measurement of temperature distribution on the surface of temperature radiatiors, $Z$. Instrumentenk. 71,22 ( Jan.).

Mak, W.H., Sodium I ine reversal temperature measurements in shock-tube flows, Toronto U. Inst. Aerophysics (Canada) UTIA-TN-66 (May); AD-419307; N63-19188. MCGregor, W.K., Spectroscopic measurements in plasma, Nor thwestern $U$. and Am. Inst. Aeronautics and Astronautics, Biennial Gas Dynamics Symposium, $5 \mathrm{th}$, PhysicsChemical Diagnostics of Plasmas, Evanston, 111., (Aug. 14-16); Nor thwestern University Press (1964), p. 143.

Meyer, J.H., and J.P. Puckett, A rotary kiln sheli temperature scanner, Elec. Eng. 82, 618 (Oct.).

Miller, J.T., Revised course in industrial instrument technology. Chapter 10. Radiation pattern thermometers on pyrometers, Instr. Pract. 18, 153 (Feb.).

Moffit $t, G .$, Study of a temperature measuring system for the $1000^{\circ} \mathrm{C}$ to $2500^{\circ} \mathrm{C}$ range, Wright-Patterson AFB, ohio, FI ight Control Lab. ASD-TR-61-487; AD274794 ; N63-16853.

Nadaud, L., and M. Gicquel, optical measurement of high temperatures, NASA Sci. and Tech. Aerospace Rept. N-15329.

Ohm, E.A., and W.W. Snell, A radiometer for a space communications receiver, Bell System Tech. J. 42, 2047 (Sept.).

Pekker, I.I., E.I. Fandeev, and V.E. Shuksheenov, Radiation temperature transducer for moving surfaces, Izv. vyss. ucheb. Zaved. Priborostr. 6, 145.

Peloquin, R., and $M$. We iss, Airborne instrument for precision measurement of sea surface temperature using infrared radiation emitted by the sea, Marine Sci. Instr. 2, 61 .

Penzias, G.J., and R.H. Tourin, Measure- ment of temperature ingaseous detonations by monochromatic radiation pyrometry, ARL 6385 (May); AD-418763; N63-15058.

Percy, J.W., Basic oxygen steelmaking-con$t i$ nuous bath temperature measurement, Proc. Instr. Soc. Am. 18, Paper 21.2.63.

Peuteman, A., New pyrome Ter using a lead sulfide cell. Surface measurement of temperatures over $100^{\circ}$, Rev. Gen。 Ther$\mathrm{mi}$ que 2,417 .

Poskacheí, A.A., Radiation measurement of temperatures below $800^{\circ}$, Tsvetn. Metal. 36, No. 9, 76 .

porter, R.A., Significance of radiative sky temperature in the determination of the apparent temperatures of materials, Rand Corp. The application of precise microwave technology to satellite meteorology, A Symposium (Aug. 1963), p. 157 .

Powling, J., and W.A.W. Smith, The surface temperature of burning ammonium perchlorate, Combus t. Flame $7,269$.

Ramsey, P.W. et aT, Infrared temperature sensing systems for automatic fusion welding, Welding $J .$, Res. Suppl. 42, 3375 ( $A \cup g \cdot)$.

Rowen, T.R., Black body radiation tables, Army Missile Command, Huntsville, Ala. TN-AMSMI-RNR-1-63: AD-418979; N64-13856.

Ryan, L.R., H.J. Babrov, and R.H. Tourin, Infrared spectra and temperatures of plasma jets: spectrometric and spectroradiometric measurement of plasma jet temperature distributions, Wright-Patterson AFB, Ohio, Aeronautical Research Labs., ARL63-35 (Feb.); AD-404867; N63-16512.

Schwarz, F., Infrared detectors, ElectroTechnol. (N.Y.) 72, 116 (Nov.).

Semikin, I.D., A radiation thermometer, Foreign Tech. Div., Air Systems Command, Wright-Patterson AFB, Ohio, FTD-TT-63-64; $A D-409749$; N64-21943.

Simmons, F.S., Spectroscopic pyrometry of gases, flames and plasmas, ISA Trans. 2 , $168($ April).

Sorgenicht, W., Radiometer based on the Gerlach principle and radiometer probes in industrial use, Elektrowarme 21, 45 (jan.).

Taft, W.C., K.C. Stotz, and E.H. Holt, A gated radiometer for plasma after-glow study, IEEE Trans. on Instrumentation and Measurement $\mid M-12,90$ (Sept.).

Takata, S., on the procedures and the accuracy of brightness matching in optical pyrometry, NatI. Res. Lab. of Metrology (Japan) Bull. No. 7,7 (Nov.).

Tourin, R.H., Recent developments in gas pyrometry by spectroscopy, AFOSR $\rfloor 1483$; AD- 427539 .

Tourin, R.H., L.R. Ryan, and H.J. Babrov, Some spectrometric and spectroradiometric measurements of temperature in plasma jets, N63-23486.

Tsuchiya, S., I nstantaneous temperature measurement by a modified sodium-D 1 ine reversal method, Nippon Kagaku Zasshi 84 , 300.

Walker, M., J. Roschen, and E. Schlegel, An infrared scanning technique for determination of temperature profiles in microcircuits, Trans. Inst. Elect. Electron. 
Engrs. ED-10, 263 (july).

Wildey, R.L., Bolometric-correction and effective temperature scale, Nature 199, 988.

Woolvet, G.A., and J.M. Alexander, Radiation pyrometer for temperature measurement in the hot extrusion of aluminum, J. Inst. Metals 92, 430.

Adaptable radiation pyrometer, Engineer 216,781 (Nov.).

A pyrometer with characteristics independent of emissivity, Control Z, 135

(Sept.).

NBS photoelectric pyrometer increases accuracy in temperature measurement, Ind. Heating 30, 660 (Apri)).

Plasma temperature in fusion research, J. Franklin Inst. 276, 270 (Sept.).

Radiometer measures temperatures to $2500^{\circ}$ C, Electron. Design 11, 78 (May).

Test equipment for high temperature studies; optical pyrometer, Engineering 196, 93 .

\section{4}

Allen, R.A., Nonequilibrium shock front rotational, vibrational and electronic temperature measurement, NASA Contract Rept. 58673; N64-28885.

Alvares, N.J., Measurement of the temperature of the thermally irradiated surface of alpha-cellulose, AD-600768; N64-229 66 .

Anufrier, A.A., and L.V. Leskov, Optical pyrometry of nonuniform light sources, Optika i Spektroskopiya 16, 325 .

Beattie, J.R., The applicafion of radiation pyrometry to glass temperature measurement and control, Proc. Instr. Soc. Am. 19, Paper No. 4 (Feb. 1).

Bernard, B., Determining emissivity, Inst. Control Systems 37, 87 (May).

Boberskii, G.A., Instrument for measuring spectral black-body radiation factors, Measurement Techniques No. 8, 675(Feb.).

Bowen, T.R., Blackbody radiation tables, $A D-418979$.

Breqev, L.E., Spectroscopy of a supersonic plasma. Il Exitation temperature, Arnold Eng. Develop. Center AEDC-TDR-64196 (Sept.); AD-447735; N64-31069.

Brodi, G., A.E. Abbott, and D. McCright, Evaluation of infrared radiation pyrometer for measuring remelt pour temperatures, U.S. At. Energy Comm. Rept. NLCO890.

Broussaud, G., and P. Fombonne, The application of Hertzian radiometry for measuring the temperature of the atmosphere, J. Inst. of Navigation 17, 418 (oct.1.

Buchele, D.R., Nonlinear-averaging errors in radiation pyrometry, NASA Tech. Note D-2406 (Aug.).

Buchele, D.R., Radiometer-pyrometer for analys is of gaseous combustion products, NASA Tech. Note D-2405; N64-27092.

Burns, J., Research on effects of arc fluctuations on spectroscopically determined temperatures in arc plasmas,
N64-14777.

Burton, J.T.A., and J.A. Hicks, Detonation emissivities and temperatures in some $1 \mathrm{i}$ quid explosives, Nature 202, 758 MMay 23).

Cammerer, J.S., F.C. Cammerer, and G. Fischer, Measurement of surface temperatures and of thermal radiation of large industrial equipment of uneven temperature, Brennstoff-Warme-Kraft 16, 120 (Mar.).

Caulton, G.K., Ratio pyrometer ignores surface variations, Control Eng. 11, 111 (nov.).

Christenson, R.W.S., Environmental errors in use of the airborne infrared radiation thermometer to measure sea-surface temperature, AD-601473; N64-27622.

Combs, H.C., Meteorological applications of infrared radiometry, AD-425911; N6419406 .

Doering, H., and P. Shahinian, Brightness and two-color pyrometry applied to the electron beam furnace, Naval Research Lab Wash., D.C., NRL-6062 AD-602292; N64-2691

Duchon, C.E., Estimates of the infrared radiation temperature correction for cyIindrical temperature sensors, J. Appl. Met. 3, 327 (June).

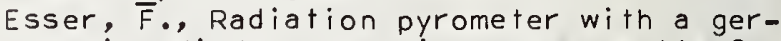
manium diode as receiver, Neue Hutte? $612(0 \mathrm{ct}$.$) .$

Filippov, L.P., N.A. Tuqareva, and L.I. Markina, Methods for determining small pulsations of high temperature and their application to determining metal heat capacities, Inzh. Fiz. Zh. 7 , 3 (June).

Finkelshtein, V.E., Precise determination of effective wavelengths of spectro-pyrometers, Measurement Techniques No. 1, $43(J u \mid y)$.

Fussell, W.B., and J.B. Schutt, Temperature of a gray body most closely fitting the solar extra terrestrial spectrum, NASA Tech. Note D-1845.

Gallagher, G., and A. Lemay, Temperature measurements of the near wake generated by hypervelocity bodies, N64-29423.

Hooker, W.J., Preliminary hypervelocity wake brightness temperature measurements, $A D-434999 ; N 64-20139$.

Houston, J.M., and P.K. Dederick, Pyrometer correction due to Dimer absorption, AD430855; N64-16625.

Izakov, M.N., Measuring the temperature of the atmosphere with the aid of satelliteborne instruments, NASA-TT-F-8569.

Kamada, 0., Method of measuring target temperature in a solar furnace, Appl. Optics $\underline{3}, 1397$ (Dec.).

kandyba, V.V., The method and instrument for measuring temperatures of $f$ lames, gas. flows and plasmas, Acta Imeko 2, 359; NSA $19-46734$.

Kanzler, R.J., An instrument for air temperature measurement using infrared emission of $\mathrm{CO}_{2}$, Bull. Am. Meteorol. Soc. 45, 48 .

Kennedy, R.H., Infrared temperature measurement and its application to textile finishing operations, Am. Dyestuff Reporter 53, 56 (jan.20). 
Kirenkov, 1.1., Particular features in the development of radiation pyrometry, Measurement Techniques, No. 4, 330 (Nov.).

Kohler, W., and R. Fischer, Temperature measurement by dispersion filters, optik 21, 624 (Nov.).

Laramore, G.E., and D.M. Johnson, A method for determining the effective emitting temperature of a radiating body, Naval Ammunition Depot, Crane, Ind., Research and Development Dept. Rept. RDTR-40 (Aug. 3); AD-604015; N65-10466.

Lieneweg, F., and $K$. Menge, A two-color automatic pyrometer, Mesures 29, 67 (Mar.).

Magison, E.C., The "whys" of radiation pyrometry, instrumentation, 17, 19.

Meredith, R. et al, Superheterodyne radiometers for short millimeter wavelengths, Electronics Record 1964, 241 (Feb.).

Mikelson, W., Comparing pyrometer methods for hot strip applications, ISA J.11, 61 (Sept.).

Montgomery, P.W., The detection of turbine wheel temperatures by infrared radiation instrumentation, AD- 426917.

Muller, G.0., Contactless temperature measurement with the aid of semiconductor filters, Acta Imeko 1964, 383 Paper No. 23-DDR-233.

Muntz, E.P., and S.J. Abel, The direct measurement of static temperature in shock tunnel flows, AD-436700; N64-245 86.

Murray, B.C., and R.L. Wildey, Surface temperature variations during the lunar night time, N64-20608.

Nadaud, L., and M. Gicquel, optical high temperature measurement, AGARD ograph No. 68,281 (1962), Publ. 1964 (France). Napier, D.H. et al, Temperature measurement in a chemical shock tube by sodium I ine reversal and $C_{2}$ reversal me thods, A|AA J. 2, 1136.

Okayama, S., Photoelectric optical pyrometer, Tokyo Kogyo Daigaku Gakuko No. 28,1 .

overington, I., and D.J. Williams, Colour densitometry applied to temperature measurement, R \& D No. 30, 38 (Feb.).

Parkinson, W.H., and E.M. Reeves, Design and construction of a new shock tube and experimental measurement of temperatures and oscillator strengths, AD- 4335 47; N64-22226.

Paul, F.W., Temperature measurements with an optical pyrometer under adverse conditions, Appl. Optics 3,297 (Feb.).

Paul, M.C., and P.E. Ober̆g, Modified pyrometer temperature measurement technique, Rev. Sci. Instr. 35, 1078 (Aug.).

Penzias, G.J., R.H. Tour $\overline{i n}$, and S.A. Dolin, Infrared techniques for air temperature measurements in a hypersonic wind tunnel, AD-608983.

Platunov, E.S., and V.B. Fedorov, Use of photographic pyrometry in thermo-physical studies, Teplofiz. Vysokikh Temperatur, Akad. Nauk SSSR $2,628$.

Reeves, E.M., and W.H. Parkinson, Temperature measurement for shock heated pow- dered solids, AD- 433550 .

Reynolds, P.M., A review of multicolor pyrometry for temperature below $1500^{\circ} \mathrm{C}$, Brit.J.Appl. Phys. 15, 579 (May).

Richard, B. et al, Measurement of temperature by Hertzian radiometry, Mesures 29 , 85 (Sept.).

Roberts, A.S., and W.H. Bennett, Plasma temperature measurement for the hollow cathode discharge, J. Appl. Phys. 35, 3434 (Dec.).

Robinson, D., Heavy particle temperature measurements in a nitrogen plasma by a spectroscopic method, J. Quantitative Spectroscopy 4 , 335; AD-440101.

Roth, J., Measured temperatures of strong shock waves in argon, J. Appl. Phys. 35, 1429 (May).

Schofield, D., Effect of laminar boundary layer development on spectrum-line reversal temperature measurement: dispersion line profile, N64-14237.

Shcherbina, D.M., Temperature measurement in solar furnaces, High Temperature $\underline{2}$, 84 (Jan.-Feb.).

Soltyk, V.Ya., and V.G. Tishchenko, Pyrometer for remote reading of temperatures (exchange of experience), Ind. Lab. 30 , 1593 (oct.).

Surh, M.T., and M.G. Whybra, Theoretical studies of a radiation balance, NASA Tech. Note $D-2246$.

Svet, D.Ya., and T.N. Zavarza, Selection and rational utilization of the spectral sensitivity of photocel Is in bichromatic pyrometry, Measurement Techniques No. 2, 107 (Aug.).

Tingwaldt, C., and $\mathrm{J}$. Schley, Two new optical methods for the laboratory determination of surface temperatures of soI ids, Acta Imeko 1964, 353 Paper No. 23DBR- 152 .

We iss, M., High temperature ultraviolet radiometer, Instr. Control Systems 37 , 95 (May).

Wells, A., and R.H. Kennett, Temperature measurements on a plasma jet, Aeronautical Research Council (G.B.) ARC-CP-756; N65- 10563 .

Wilson, J., Discrepencies between theoretical and experimental values of temperature behind a shock wave, Aeronautical Research Council (G.B.) ARC-CP-712; AD407106; N64-18156.

Wormser, E.M., Radiation thermometer with in-line blackbody reference, Instr. Control Systems 37, 101 (Dec.).

Emissivity-compensated radiation pyrometer, Instr. Pract. 18, 291 (Mar.).

Radiation pyrometer, Prod. Eng 35 , 94 (Apr. 27 ).

\section{5}

Bakhir, L.P., Optical pyrometry of ronuniform sources of radiation, Zh. Prikl. Spektroskopi i, Akad. Nauk Belorussk. SSR 2 , 279.

Barber, R., and J.D. CresswelI, An evaluation of the accuracy of radiation pyrometers in a rolling mill, Proc. 15th 
NatI. Conf. Instr. Iron Steel Ind. 15, paper No. 12 .

Berty, M., Spectrographic measurement of the temperature of a hydrogen plasma jet by the Stark effect, J.Phys. 26, 469 (Aug.).

Bivans, E.W., Scanning radiation pyrometer, Instr. Control Systems 38, 115 (July).

Burley, B.W., Radiation pyrometers to measure the temperature of small objects, Instr. Eng. (G.B.) 4, 33 (April).

Eppig, H.J., E.C. Magison, and D.F. Wood, High speed radiation pyrometer for glass temperature measurement, Glass Ind. 46 , 457 ( Aug.).

Exton, R.J., A variable exposure photographic pyrometer, ISA Trans. 4,365 (oct.).

Ferriso, C.C., and C.B. Ludwig, An infrared band ratio technique for temperature determinations of hot gases, Appl. Optics 4,47 ( Jan.).

GaTley, J., M. Rouannet, and G. Urbain, New photoelectric pyrometer for industrial applications, Engr. Dig. (London) 26, 91 (May).

Greig, J.R., The sodium D-I ine reversal me thod of temperature measurement in ionized flame gases, Brit.J.Appl. Phys. 16, 957.

11 in, $V \cdot M_{\text {. }}$, Infrared semiconductor optical pyrometer, Measurement Techniques No. 3, 250 (Aug.).

Kogan, A.V., optical systems of pyrometers for measuring the temperature of small bodies, Teplofizika Vysokikh Temperatur 3, 747 (Sept.).

Ko Ftenstette, J.P., Fast response optical pyrometer, ISA Trans. 4, 270 (July).

krakow, B., Determinatioñ of hot-gas temperature profiles from infrared emission and absorption spectra, AlAA J. 3, 1359 (july).

Lauver, M.R., J.L. Hall, and F.E. Belles, Shock tube gas temperature measurements by infrared monochromatic radiation pyrometry, NASA Tech. Note D-2955 (Aug.); N65-30899.

Lieneweg, F., Temperature measurement-radiation pyrometer, Arch. Tech. Messen. No. 359, 285 (Dec.).

Lord, J.S., Brightness pyrometry, Instr. Control Systems 38, 109 (Feb.).

Molchanov, V.M., Use of an optical method for measuring temperature differences, Instr. Exp. Tech. No. 1, 165 (Aug.).

Montgomery, P.W., and R.L. Lowery, Turboje t temperature by IR pyrometry, ISA J. 12, 61 (April).

Morgan, J.P., Radiant energy measurement, Instr. Control Systems 38, 127 (July).

Nodwel I, R.A., and J.C. Irwin, A method of determining the reversal temperatures in an excited gas, Can. J. Phys. 43, $1182(\mathrm{~J} u \mid y)$.

Reed, T.B., and J.T. Roddy, optical pyrometer measurement of $r$. f power, Rev. Sci. Instr. 36, 620 (May).

Reingold, L., Theoretical study of the colour temperature and the real tempera- ture of a body radiating in the visible spectrum, C.R. Acad. Sci. (France) 260 , 1111 (Jan. 25).

Reingold, L., Experimental determination of relative emissive monochromatic powers and true temperatures of radiating bodies in the visible and near infrared range, Compte Rend. 261, 71 .

Sadykov, B.S., Temperature dependence of the radiating power of metals, High Temperature 3, 352 (May-June).

Suckewer, s?, Spectral measurements of temperature in the plasmatron, High Temperature 3, 178 (Mar.-April).

Svet, D.Ya., Comparison of classical methods of pyrometry for real bodies with a continuous emission spectrum, High Temperature 3, 407 (May-June).

Tourin, R.H., and B. Krakow, Applicability of infrared emission and absorption spectra to determination of hot gas temperature profiles, Appl. Optics 4, 237 (Feb.)

verch, J., Analys is of $q$ tical-pyrometrical temperature measurements, optik 19, 640 (May); NASA-TT-F-9359; N65-23794.

Wright, M.A., Some spectroscopic methods of gas temperature measurement in the range $3000^{\circ}$ to $10,000^{\circ} \mathrm{K}, \mathrm{Brit}$. Coal Util. Res. Assoc. Monthly Bull. 29, 137.

Yamamoto, N. et al, Effective utilization of radiation and two-color pyrometers, J. Metals $17,718(\mathrm{Ju} \mid \mathrm{y})$.

Young, F.L., Use of infrared instrumentation for detection of jet engine turbine wheel temperature, N65-18398.

Young, L.A., Infrared temperature measurement of the laminar wake of ahypersonic sphere, AlAA J. 3 , 610 (April).

\section{Expansion Devices}

1958

Roshwarf, F., and J. Steinberg, Variable sensitivity gas thermometer, for we at low temperatures, Probl. Low Temp. Phys. Thermodyn., Proc. Meet ing Comm. I, Intern. Inst. Refrig., Delft, Neth. 1958, 117 .

\section{9}

Glagolev, Yu. A., Distillation of alcohol in a minimum temperature thermometer, $\mathrm{Tr}$. Nauchn.-Issled. Inst. Gidrometioval, Priborostronie 1959, No. 7, 105.

1962

Folsom, T.R., R.A. Schwartz, and F.D. Jennings, Scale errors on oceanographic mercurial thermometers, Deep-Sea Research 9 , 219.

Hale, C.E., Gas-filled thermometer for thermocouple calibration, U.K. At. Energy Authority TRG, Rept. 261 R (1962).

Jucheim, P., Attainable control precision of adjustable contact glass thermometers, Glass Instr. Tech. 6,322 .

Tulin, V.A., A field precision thermostat using mercury contact thermometers, Bull. Acad. Sci. USSR, Geophys. Ser. (8), 677 
(Nov.).

1963

Foster, R.B., Complete Immersion testing of liquid-in-glass thermometers, Proc. Instr. Soc. Am. 18, Paper No. 57-1-63.

Miller, J.T., The revised course in industrial technology. Non-electrical thermometers, Instr. Pract 17, 1323 (Dec.).

Moser, H., J. Otto, and W. Thomas, Gas thermometric measurements at high temperatures. Ill Determination of the thermodynamic temperatures of $f$ ixed Points between $4191065^{\circ}, Z$. Phys. 175,327 .

\section{4}

Holten, D.C., Static and dynamic behaviour of helium-gas thermometers be low $77^{\circ} \mathrm{K}$, Advances in Cryogenic Engineering 9, 406; Proc. of the Cryogenic Engineerring Conf., University of Colorado and the National Bureau of Standards, Boulder, Colo., Aug. 19-21, 1963, Ed. by K.D. Timmerhaus, New York, Plenum Press, 1964 U.S. At. Energy Comm. Rept. UCRL-7327, April 16, 1963.

Orlova, M.P., and D.N. Astrov, Vapor pressure of a helium thermometer for realizing the $T_{5}$ scale, Comite Consultatif Thermometrie, Comite Intern. Poids Mesures, 6e, Sevres, France 1962, 176 (Publ. 1964).

Pamely-Evans, O.G., Capsule and bulb fluid expansion instruments, Mech. World 144,415 (Oct.).

Pemberton, L.H., Fur ther consideration of emergent column correction in mercury thermometry, J. Sci. Instr. 41, 234 (April).

\section{5}

Anderson, R.L., and L.A. Guildner, National Bureau of $S$ tandards gas thermometer; Constant volume valve, Rev. Sci. Instr. 36, 615 (May).

Hagen, E.W., Dynamic gas thermometry, oak Ridge National Lab., Tenn. ORNL-P-1068; NSA 19-20277.

Hanak, B., Pressure thermometers with nitrogen filling, Jemna Mechanika a optika 10, 54 (Feb.).

Hanak, B., Pressure thermometers with nitrogen filling, Jemna Mechanika a Optika 10, 82 (Mar.).

Hanak, B., Characteristics, artificial aging, and quality of nitrogen thermometers, Jemna Mechanika a Optika 10 , 209 (July).

Lieneweg, F., Temperature measurement. Expansion thermometers, Arch. Tech. Messen No. 357, 237 (Oct.).

Moser, H., Gas thermometry at higher temperatures, Metrologia 1, 68 (April).

Swindells, J.F., Calibrafion and use of liquid-in-glass thermometers, Nat1. Bur. Std. (U.S.), Monograph 90 (Feb. 12).
Sychev, 1.A., Certain properties of liquid manometric thermometers, Measurement Techniques No. 7,627 (July).

\section{Aspirated Devices}

1962

Temme, G., A three-vent probe for measuring flow field pressure and temperature, Wiss. Ges. Luft-u. Raumfahrt, Cologne (w. Germany), Proc. of the joint meeting of the Comm. on Air-Breathing Engines and the Subcomm. on Aerodynamic Measuring Techniques, July 16, 1962, Aachen p. 26; N63-20183.

1963

Kahnwald, H., Development of a rew suction pyrometer for the measurement of higher gas temperatures, Arch. E isenhutten. 34, 673 (sept.).

1965

Forster, S., A pneumatic apparatus for measurement of high and rapidly changing gas temperatures, Arch. Tech. Messen No. 349, R13 (Feb.).

\section{Other Methods, Descriptive Articles}

1958

van Itterbeek, A. et al, Temperature measurements with an acoustic thermometer, Probl. Low Temp. Phys. Thermodyn., Proc. Meeting Comm. I Intern. Inst. Refrig., Delft, Neth. 1958, 137 .

\section{0}

Taylor, J.W., Residual temperatures of shocked copper, U.S. At. Energy Comm. Rept. LADC-573.

1961

Ato, Y., R. Huzimura, and M. Oishi, A study on radioactive self luminous compounds. II On the application of radioactive selfluminous compounds, Proc. Japan Conf. Radio-lsotopes, 4th, 607 (1961); NSA 1729965.

Hock, R., Modern electrical temperature measuring device, Chem. Rundschau 14, 528.

\section{2}

Becker, F., and W. Wal isch, Precision thermostat with optical control thermometer and controlled Peltier cooling, Z. Physik. Chem. (Frankfurt) 34, 369.

Cataland, G., and H.H. Plumb, Absolute temperatures determined from measurements of the velocity of sound in helium gas, Proc. Advisory Comm. on Thermometry to the Intern. Bur. of Weights and Measures, 6 th Session p. 175 (Sept. 26-27, 1962); Proc. Intern. Conf. Low Temp. Phys. $8 \mathrm{th}$, London 
1962, 439 (Publ. 1963); Low Temperature Physics, Butterworth's, Wash., D.C. (1963).

Cohen, B.G., Gallium arsenide diode used as low-temperature thermometer, Bell Lab. Record 40, 421 (Dec.).

Forster, S., A pneumatic pyrometer technique-description and applications, Wiss. Ges. Luft-u. Raumfahr $\uparrow$, Cologne (W. Germany), Proc. of the joing meeting of the Comm. on Air-Breathing Engines and the Subcomm. on Aerodynamic Measuring Techniques (July 6,1962 ). Aachen p. 11 .

Leroux, J.P., and M. Poncin, Determination of the temperature of surfaces from $0^{\circ}$ to $400^{\circ}$ by means of photoluminescent emmissions of thin layers, Publ. Sci. Tech Min. Air (France) Notes Tech. No. 119.

Plotkin, E.R., and E.J. Molchanov, Use of temperature indicating paints for measuring the temperatures of machine parts Ind. Lab. 28, 214 (Aug.).

Savateev, A. $V_{0}$, Compensated thermal noise thermometer, Measurement Techniques No. 2, 114 (July).

Shekhovtsov, A.F., Pneumatic contact device for measuring the temperature of pistons in working engines, Measurement Techniques No. 5, 381 (Nov.).

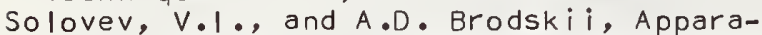
tus for measuring a temperature by means of nuclear quadrupole resonance, instr. Exp. Tech. No. 2, 332 (Nov.).

Thorne, E.A., The measurement of high temperatures by the determination of the velocity of sound waves in materials, Acoustics Congress, Copenhagen, 1962, Paper P23.

Thureau, P., Measurement of surface temperatures by photoluminescence, Journees Intern. Transmission Chaleur, Paris, $1961,2,865$ (1962).

Vernotte, P.V., Device for measurement of a quantity of heat at ordinary temperatures, Compte Rend. 255, 2914.

Electroacoustic thermometer having a frequency output, Instr. Exp. Tech. No.2, 408 (nov.).

Mechanical thermometers, Measurement and Control 1, 530 (Dec.).

\section{3}

Bouchard, $F_{.}$, and $P$. Thureau, on a new development in measuring temperatures by photoluminescence, Compte Rend. 256, 87 (Jan.).

Brodskii, A.D., An electro-acoustic gas thermometer for use in low temperatures, Feinwerk Tech. 67, 299 (Aug.).

Brodskii, A.D., and v.l. Solovev, Reproduction of the temperature scale reference points by quadrupole nuclear resonance, Measurement Techniques No. 9, 763 (April).

Chabbal, R., M. Clement, and R. Geller, Measurement of the temperature in a $P$ I G reflex pulse discharge using a Faboy-Perot interferometer, Nucl. Instr. and Me thods, 23, 325 (June).

Cohen, B.G., W.B. Snow, and A.R. Tretola, G
FaAs $p-n$ junction diodes for wide range thermometry, Rev. Sci. Instr. 34, 1091 (Oct.).

Dimick, R.C., and G.J. Trezek, Photodiode as a sensitive temperature probe, Rev. Sci. Instr. 34, 981 (Sept.).

Flynn, T.M., H. Hinnak, and D.E. Newell, An improved cyrogenic thermometer, Advan. Cyrog. Eng. 8, 334.

Fragnaud, F., Application in convection of temperature measurement by I uminescence methods, Ministeve de l'air (France) Sci. ef Tech. No. 400 (Nov.).

Haas, F.C., An evaporative film colorimetric enthalpy probe, AD-404619.

Howard, D.R., A photographic technique for the measurement of transient high temperatures, Engineer 215, 475 (Mar. 15).

Kundra, K.D., and R. Potshad, Microwave crystals as thermometers in low temperature range, Current Sci. 32, 302 (July). Levine, D., Unresolved fine structure of the nitric oxide gamma $0-0$ band for the determination of temperature, N63-14492.

Libby, H.L., The measurement of metal temperature by an electromagnetic induction method, U.S. A t. Energy Comm. Rept. HW79621 (Aug. 12, 1963); N64-15834.

Montgomery, H., and G.P. Pells, Errors in helium vapour thermometry, Brit. J. Appl. Phys. 14, 525 (Aug.).

Morozov, $\bar{V} . A .$, and L.S. Tyufyakin, measur ing the equivalent temperature of pulsetype noise radiation, Measurement Techniques No. 4, 320 (oct.).

Pallet†, J.E., Electric thermometer, Electron. Eng. 35, 313 (May).

Pearson, P.H.O., Measurement of atmospheric density, temperature and pressure at Woomera on 29th March, 1962 by the falling shere method, Res. Weapons Establishment (Australia) Tech. Note SAD-121 (May 1963); N63-19997.

Quneshi, M.H., and F.A. Farqui, Low-temperature pyrometer cones, Pakistan J. Sci. Res. $15,100$.

Richardson, P.D., A swinging thermometer, Am. J. Phys. 31, 395 (May).

Rothert, I.L., and N.P. Udalov, Semiconducfor diode as a temperature pick up, Automatika i Telemekhanika 24, 696 (May).

Shepard, G.G., The use of the junction diode as a low temperature thermometer, Ohio State Univ. Research Foundation, Antenna Lab. Columbus, Rept. 1083-22 (Jan. 1963); AD-402415; N63-18324.

Smith, P.L. Jr., Limitations on the accuracy of sonic thermometers, Midwest Research Inst., Kansas City, Mo., Rept. AFCRL 63687 (June 1, 1963); AD-412479.

Smith, W.L., and W.J. Spencer, Quartz crystal thermometer for measuring temperature deviations in the $10^{-3}$ to $10^{-6}{ }^{\circ} \mathrm{C}$ range Rev. Sci. Instr. 34, 268 (March).

Solovev, $V_{.} I$. , and A.D. Brodskii, An apparatus for measuring temperature by nuclear Quadrupole resonance, Cryogenics 3,201 (Dec.).

Willkie, D., and S.A. Fisher, Measurement of temperature by Mach-zender interferometry, Char tered Mech. Engr. 10, 612. 
Gallium-arsenide diode used as low temperature thermometer, Instr. Pract. 17, 37 ( Jan.).

ocean thermometer uses ultrasonics, Electron. Design 11, 18 (May).

Uitrasonics takes the ocean's temperature, Elect. Eng. 82, 422 (June).

Uitrasonic thermometer for low temperature determinations, J. Franklin Inst. 275, 56 ( Jan.).

Uitrasonic thermometer measures to 0.05 - F, Electronics 36, 77 (April).

\section{4}

Abel, W.R., A.C. Anderson, and J.C. WheatIy, Temperature measurements using small quantities of cerium magnesium nitrate, Rev. Sci. Instr. 35, 444 (April): U.S. At. Energy Comm. Rept. TID 19533.

Betts, D.S. et al, A susceptibility thermometer for use at very low temperatures J. Sci. Instr. 41, 515 (Aug.).

Chognot, M., Method of measuring surface temperatures using the temperature sensitivity of luminescence, Int. J. Heat Mass Transfer, 7, 577 (May).

Court, G.R., and J. Sayers, An experimental study of the use of a Langmuir probe to measure electron temperatures and densities in after glows, J.Sci. Instr. 41, 462 ( July).

crorini, L., and S. Sartori, Thermal roise and absolute temperature, Recerca Scientifica 4, 155 (March).

Doherty, $\overline{\mathrm{D}} \cdot \mathrm{D} .$, Temperature measurements in hot gases by thermal neutron scattering, NSA - 26157 .

Fogelson, 1.B., Tmperature measurement by means of germanium triodes, Instr. Exp. Tech. No. 1, 248 (Sept.).

Giedt, W.H., and J.T. Chambers, A dual element transducer for measuring high gas temperatures, ASME Winter Annual Meeting, New York, N.Y., Nov. 29-Dec.4, 1964, Paper 64- WA/HT-45.

Govelik, L.S., and I.B. Fogelson, Tests for measuring temperature by the application of triode thermal detecting units, Instr. Construct. No. 4, 31 (Apr.) Hammond, D.L., C.A. Adams, and P. Schmidt, A linear quartz cystal temperature sensing element, Proc. Instr. Soc. Am. 19, Paper No. 11 (Feb. 3).

Khan, S.A., and P.S. Kohatkar, I ns trument for measuring small temperature variations using thermocaps, Res. Ind. INew Delhi) 9, 296 (Oct.).

Larson, G.S., R.N. Lawson, and L.C. Lynnworth, Upper atmospheric sonic thermometry, Proc. Instr. Soc. Am. 19, Paper No. 19 (Jan. 5).

Lee, R.D., Some results and problems of the standardization of the photoelectric pyrometer of the National Bureau of Standards in 1961, Comite Consultatif Thermometrie, Comite Intern. Poids Mesures, 6e, Sevres, France 1962, 79 (PubI ished 1964).

Lezberg, E.A., and D.R. Buchele, Some optical techniques for temperature and concentration measurements of combustion in supersonic streams, NASA Tech. NoteD-2441.

Libby, H.L., The measurement of metal temperature by an electromagnetic induction method, U.S. At. Energy Comm. Rept. HWSA-3035 (May 3); NSA N-20282.

olsen, W.D., and H.J. Leinbach, Applicability of dual-path sound propagation measurements to temperature determination over a six-mile path, Army Electronics Research and Development Activity, White Sands, Missile Range, N. Mex., ERDA-112; AD-432009: N64-17438.

Pertsovskiy, G.A., Determination of the bath temperature in the electroslag process by the calorimetric method, N64-11920.

Peterson, J.W., and K.D. McWatters, The measurement of upper-air density and temperature by two radar-tracked falling spheres, N64-17831.

Shaffstall, E.L., A measurement of the roise temperature of a shock- induced plasma at 420 MCPS and 690 MPCS, AD-427067.

Terao, K., Flame temperature measurement using the double probe method, Japan J. Appl. Phys. 3, 169 (March).

Terao, K., Electron temperature in a $f$ lame front, Japan J.Appl. Phys. 3, 486.

Uo, K.A., Measurement of the perpendicular temperature of the $\mathrm{C}$-stellarator plasma by the diamagnetic coil, N64-21735.

Weder, E., An ultrasonic thermometer for low temperatures, Kal tekchnik 16, 398 (Dec.).

willkie, D., and S.A. Fisher, Measurement of temperature by Mach-Zender interferometry, Proc. Inst. Mech. Engrs. (London) 178,461 .

Acoustical thermometer establishes provisional low-temperature scale, Nat. Bur. Std. (U.S.) Tech. News Bul).48, 189 (Nov.).

Colour strip thermometer, Engineer 217, 447 (March 6).

\section{5}

Bernert, R.E., Cryogenic temperature gage, Chem. Eng. 72, 140 ( July).

Bos, L., Probe for the measurement of gas compositions and temperature in the fusion zone of a cupola furnace, Metalen $20,79$.

CaTvet, E., and C. Guillard, Microcalorimeter equipped with semiconductor thermoelements, Compte Rend. 260 (Groupe 7), 525.

Carnevale, E.H., L.C. Lynnworth, and G.S. Larson, High temperature measuring device. Final report, Parameters Inc., Waltham, Mass., NASA-CR-54339 (Feb. 1); N65-24568.

Cheng, D.Yu., and P.L. Blackshear Jr., Factors influencing the performance of a fast response, transpiration cooled, high temperature probe, Am. Inst. of Aeronautics, Preprint No. 65-359; NSA 19-44204.

Fogel'son, I.B., Measuring temperature with germanium transisor thermoelements, Measurement Techniques No. 12, 1053 (May).

Fogel'son, 1.B., Measuring temperature with silicon transistors, Instr. Exp. Tech. No. 4, 915 (Feb.) 
Fogel'son, I.B., Operation of the transistor as a thermosensitive element, N6510150 .

Giedt, W.H., A dual element transducer for measuring high gas-stream temperatures, Trans. ASME, Ser C ( J. Heat Transfer) 87,397 (Aug.).

Hammond, D.L. et al, A I inear, quartz crystal, temperature sensing element, ISA Trans. 4, 349 (Oct.).

Hammond, $\bar{D} \cdot L .$, and $A$. Benjaminson, Linear quartz thermometer, Instr. Control Systems 38, 115 loct.).

Joyce, $\overline{\mathrm{D} . E}$., Capacitance temperature sensor, General Electric Co., Cincinnati, Ohio, GEMP-89 (June 25); N65-26336; NSA $19-36748$.

Kerman, M., Investigation of microstate electronics, gallium arsenide as cyrogenic temperature sensors, Final report, Simmonds Precision Products Inc., Tarrytown, N.Y., Rept. No. 11029 (July): AD$469914 \mathrm{~L}$.

Lang, S.B., and F. Steckel, Study of the ultrasensitive pyroelectric thermometer, Rev. Sci. Instr. 36, 1817 (Dec.).

Lovborg, L., A line ar temperature to frequency convertor, J. Sci. Instr. 42, 611 ( Aug.).

Malozemov, V.V., and I.A. Turchin, Determination of temperature fields with the interferometer, Inzh. Fiz. Zh. (USSR) 8, $182(\mathrm{Feb}$.$) .$

oleson, S., An improved sonic anemometerthermometer, AD-619996; N65-34557.

Planer, G.V., and P.J. Evison, Temperature sensing capacitors, Electron. Components 6, 217 (March).

Plumb, H.H., and G. Catal and, Absolute temperature scale from $4^{\circ} \mathrm{K}$ to $20^{\circ} \mathrm{K}$ determined from measurements with an acoustical thermometer, J. Res. Natl. Bur. Std. (U.S.) 69A, 375 (July).

Reeves, D., M.E. Inglis and L. Airey, The fluid oscillator as a temperature sensor, Fluid Logic and Amplification Conference, Paper No. D1, (Sept. 1965); N65-36403.

Re isman, E., and P.M. Sutton, Measurement of air temperature distributions with the schlieren interferometer, Appl. Opt. 4, 144 ( Jan.).

Robins, P.J., Temperature measurements by ulirasonics, Ind. Electron. 3,482 (oct.).

Sargeant, D.H., Note on the use of junction diodes as temperature sensors, J. Appl. Meteorology 4,644 (oct.).

Sato, M., Electrochemical geothermometer; a possible new method of geothermometry with electroconductive minerals, Econ. Geol. 60, 812 (June).

Wheeler, $\bar{E} . E_{\text {. }}$, Sensitive suppressed zero thermometer, J. Sci. Instr. 42, 42 ( Jan.).

8. Special Applications, Method Not Specified in Title

1961

Roessler, F., Temperature measurement of a flame combined with a high-frequency torch, Proc. Intern. Conf. Ionization Phenomena Gases, 5th, Munich, 1961, 1, 842 (Publ. 1962).

1962

Bereznikov, V.V., and G.A. Lavrenter, Thermocouple installation in parts made of polymer material, Ind. Lab. 28, 526(oct.)

Danbery, J.E., The equilibrium temperature probe, a device for measuring temperatures in hypersonic boundary layers, Advances in Hypervelocity Techniques, Plenum Press, N.Y. 1962 , p. 693.

Froebel, A.T., on the measurement of temperatures in shock waves, N65-36373.

Hukuo, N., Measurement of temperature in a solar furnace, Nagoya Kogyo Gijutsu Shikensho Hokoku $11,303$.

Michalski, L., Measurement of surface temperature of rotating cylinders, Pomiary, Automat., Kontrola 8, 407 (Sept.).

Pavia, R.V., and D.H. Edwards, A Precision jet pipe temperature indicator for flight use, Aeronaut. Res. Lab., Meljourne, Australia ARL/F-33 (Sept.); N63-19903.

Rozenblit, G.B., Measurement of small temperature variations on the surface of solid bodies, Measurement Techniques No. $2,120(\mathrm{Ju}) \mathrm{y})$.

strauss, W., The measurement of high gas temperatures, Australian J. Instr. Technol. 18, 141 (Nov.).

\section{3}

Arai, T., Studies on the air temperature measurement, Army Missile Command, Huntsville, Ala., Redstone Scientific Information Center, RSIC-31 (July 23); N63-19755

Bahgat, F., Furnace gas temperature evaluation for marine boilers, Naval Eng. J. 75,647 .

Be $\overline{c k}, G .$, and $R$. Bigot, On the recording of temperature differences between the center and surface of a cylinder of nickel cooled by tempering, Compte Rend. Acad. Sci. 256, 619 (Jan. 14).

Benedict, R.P., High response aerosol probe for sensing gaseous temperature in a twophase two component flow, Trans ASME $1 \mathrm{~J}$. Eng. Powerl 85A, 245.

Benson, J., Gauging $f$ iber temperatures, Rubber Age 93, 410 (June).

Branger, M., Veil cooling of radial-flow turbines, The Garrett Corp.. A ir Research Manufacturing Div. Rept. K-500 (Oct. 11).

Coombe, R.A., Measuring temperatures in the range $1000^{\circ} \mathrm{C}$ to $5000^{\circ} \mathrm{C}$. Part I, R \& D No. 28, 18 (Dec.).

Crabtree, R.I., and G. A. Wheeler, Radiation effects investigation of selected transducers and materials for Nerva program. Volume I, U.S. At. Energy Comm. Rept. FZK-159-1 (Apri I 26).

Critides, L., Instrument measures thread surface temperature, Ind. Eng. Chem. 55, 10 (Sept.).

Crook, R.F., Determining the operating temperature of an $A C$ coil, Electro- Technol 
(N.Y.) 71, 160 (May).

Dudnik, L.A., and E.B. Perchik, Measurement of the grid temperature of an electron tube by change of resistance, $\operatorname{lnzh}$. $\mathrm{Fiz}$. Zh. 5, 110 (Mar.).

Gee, K.H., Metal temperature and slag analys is improve blast-furnace control, J. Metals 15,512 (Ju/y).

Geil, F.G., and J.H. Thompson, An in situ temperature sensor, Marine Sci. Instr. 2,35 .

Gräves, F.L., and H.S. Loveless, Convenient measurement of deflaction temperature under load and vicat softening point, Mater. Res. Std. 3,33 (Jan.).

Grey, J., Sensitivity analys is for the calorimetric probe, Rev. Sci. Instr. 34, 857 (Aug.).

Gutzwiller, W.R., Tool measures piston temperature of Diesels, Abstract SAE J. 71,83 (May).

Headly, J.A., and J. McGeagh, Specimen heating with temperature measurement from $-150^{\circ} \mathrm{C}$ to $2200^{\circ} \mathrm{C}$ inside the EN6 electron microscope, J. Sci. Instr. 40, $484\left(\mathrm{CC}^{+}\right)$.)

Hudimac, A.A., J.R. Olson, and D.F. Brumley, A mobile instrument of ocean temperature in the thermocline region, Marine Sci. Instr. 2, 49.

Karp, T., Electronic dark room thermometer, Radio Electronics 34,60 (oct.).

Kourim, G., Electrical temperature measuring device for installation where danger of explosions exist, Arch. Tech. Messen. No. 334, 257 (Nov.).

Kudlacik, H.W., and D.M. Willyoung, Local rotor winding temperature measurements for large turbine generator fields, Power Apparatus and Systems No. 64, 687 (Feb.).

Kurzrock, J.W., Selection of surface thermometers for measuring heat flux, Cornell Aeronaut. Lab., AD-404770; N6318751 .

La Fond, E.C., Towed sea temperature structure profiler, Marine Sci. Instr. 2, 53 .

Lee, $P$. W. et al, Method for predicting temperatures in continuous hot strip mills, J. Inst. Iron Steel (London) 201, 270 .

Leontev, A.K., A simple method for determining the temperature of a heat transfer surface, Inzh. Fiz. Zh. 5, 78(July).

Lubbs, E.K., Device for measuring temperature in a closed rotating flask, J. Chem. Educ. 40, 200.

MacHattie, L.E., Temperature measurement of textile fabrics under intense irradiation, Brit. J.Appl. Phys. 14, 267 (May).

Malin, W., J. Davison, and C. Krollman, Development of a de iced fast response dual element total temperature sensor, AD- 622247 .

Markussen, B.H., How to estimate piston temperature, Abs tract: SAE J. 71, 97 (May).

Marshall, G.S., and R.H. Henderson, Recording temperatures in deep bore holes,
Engineering 196,540 (oct. 25).

Masalovich, G.T.' Local temperature measurements in forging and stamping, Measurement Techniques No. 11, 935 (June).

MCLaren, T.I., J.N. Fox and R.M. Hobson, Double probe measurements of electron temperatures in a shock tube, Nature 198, 1264 (June 29).

Miers, B.T., and N.J. Beyers, Rocket-sonde wind and temperature measurements be tween 30 and $70 \mathrm{KM}$ for selected stations, Army Electronics Research and Development Activity, White sands Missile Range, $N$. Mex.. Rept. ERDA-70 (Sept.); N63-22783.

Moeller, F., and H. Meyer, Surface temperature measurement, Arch. Tech. Messen. No. 323, 269 (Dec. 1962 ) No. 324, 1 ( Jan. $1963)$.

Nanigan, J., Temperature measurements and heat transfer calculations in rodset nozzle throats and exit cones, Proc. Instr. Soc. Am. 18 Paper No. 29.3.63.

or lova, M.P., and D.N. Astrov, Measurement of remperatures below $10^{\circ} \mathrm{K}$, Measurement Techniques No. 8, 669 (Feb.).

Peris, T.A., and J.J. Hartog, Pyroelectric transducers for heat-transfer measurements, ISA Trans. 2, 21 (Jan.).

Petit, $Y_{\text {., }}$ and M. Dembno, Measurement of surface temperatures of rotating machine elements Mesures Controle Ind. 28, 699 (May).

Redstreake, W.N., Sensors promise to close loop on control of molten metal, Iron Age 191, 73 (June).

Reid, A.F., Filament temperatures from geometry-independent electron emission junctions, J. Electrochem. Soc. 110,135 (Feb.).

Smith, R.A., Atmospheric radiative temperature measurements, Rand Corp., The Application of Passive Microwave Technology to Satellite Meteorology, A Symposium (Aug. 19631 p. 37; N63-16497.

Tassicker, $0 . j .$, Effect of inductance on the measurement of winding temperature in electrical plant, Proc. Inst. Elec. Engrs. (London) 110,419 (Feb.).

Teweles, S., Time section and hodograph analysis of Churchill rocket and radiosonde winds and temperatures, Intern. Geophys. Year World Data Center A. Wash., D.C., A Third Compilation of U.S. IGY-IGC Rocket Program Results, (April 1963) p. 72; N63-19679.

Wald, D., Measuring temperature in strong fields, Instr. Control Systems 36, 100 (May).

Zinman, W.G., Temperature measurements in hydrogen-oxygen detonations, J. Chem. Phys. 39, 3534. A low-temperature pyrometer Control 6,102 (Feb.).

Evaluation of soil temperature thermometers, Army Electronic Prooving Ground, $j$ For $t$ Huachuca, Ariz., AD-408192.

Generator temperatures monitored by failsafe system, Elec. World 159, 116 (Feb. 251 .

Mapping the temperature of the ocean surface, New Scientist 18,723 (July).

Measuring surface temperature of subliming solids, $R$ \& $D$ No. 21,42 (May). 
160 (Oct.).

Pyrometer reads molten iron temperature continuously, Foundry 91,86 (Nov.).

Surface pyrometer for high speed cylinders, Power and Works Eng. 58, 47 (March).

Temperature measuring screws, Eng. Mater. and Design 6, 239 (April).

Temperature probe for moving sheets, belts and drums, R \& D No. 18, 52 (Feb.).

\section{4}

Benson, R.S., Measurement of transient exhaust temperatures. in internal combustion engines, Engineer 217, 377 (Feb.)

Boynion, F.P., Chemical kine $\overline{\dagger i c}$ analys is of rocket-exhaust temperature measurements, AIAA J.2, 577 .

Cato, G., Measurement of free air properties from on board a large launch vehicle, N64-24906.

Chappel, R.M., Bonding of electrical leads to germanium for ultrahigh-vacuum and high temperature measurements, J. Appl. Phys. 35, 2783 (Sept.).

Chen, F. F., Double-probe method for unstable plasmas, Rev. Sci. Instr. 35, 1208 (Sept.).

Chizhov, A.F., Temperature measurements of the free atmosphere taking into account the recombination of atoms, N6424591 .

Clark, G.Q., and J.G. McCoy, Rocketsonde measurement of stratospheric temperature, Army Electronics Research and Debelopment Activity, White Sands Missile Range, N. Mex., ERDA-24Z: AD-453993; N65-17924.

Clayton, W.H., B.J. Eckelkamp and J.H. Machetta, A wet and dry bulb temperature measuring system for microemteorological application, Texas A \& M Univ. College Station AFCRL-64-938; AD-610107; N65- 18982 .

Cowne, R.W., Atmospheric temperature measurement from aircraft, Proc. Inst. Soc. Am. 19, Paper No. 19 (Jan. 4).

Fend Iy, J.R. Jr. and K.G. Hernquast, Ionization mechanism and electron temperature in cesium arecs, Proc. IEEE 52, 964 $(A \cup g \cdot)$.

Fischer, W.A., and H.J. Fleischer, Continuous temperature measurement for basic oxygen steelmaking, J. Metals 16, 483 (June).

Grabowsky, W.R., L.Y. Lam, and D.A. Durran, Double shock tube method for simultaneous determination of high pressure and temperature of an enclosed gas, N6416129.

Haas, A., Ambient temperature compensated non-contacting surface thermometer, Acta Imeko 1964, 339 Paper No. 23-HU-105.

Hamilton, R.L., and C.H. Miller, Yarn temperatures attained during cyclic straining and heat transfer properties of yarns, Textile Res. J. 34, 20 (Jan.).

Hvetz, J., J.P. Leroux, and G. Palazy, Contribution to the measurement of surface temperatures, Compte Rend. 259, 2801 (oct.).
Kirchhoff, R.H., Calorimetric heating rate probe for maximum response time interval, AlAA J. 2, 966 (May).

Kirk, W.B., Flue gas temperature measurement procedures, ASHRAE J.6, 40 (June).

Kordig, J.W., Backside temperátures of an interval insulator in a solid-propellant motor, AIAA J. 2, 1475 (Aug.).

Lapworth, K.C... Temperature measurements in a hypersonic shock tunnel, AGARDograph 1964, 267: AGARD, The high temperature aspects of hypersonic flows (1964) 255.

Lenschaw, D.H., and J.A. Dutton, Surface temperature variations measured from an airplane over several surface types, J. Appl. Meteorol. 3, 65 (Feb.)

Logan, C.A., and R.P. Johnson, Automatic temperature measurement as applied to a cement kiln, Proc. Instr. Soc. Am. 19, Paper No. 4 (Jan. 1$)$.

Lorenz, D., Measurement of the earth's surface temperature from aircraft, N64-24953.

Meieran, S., Temperature sensor for strain gage transducer, Electronics 37,77 IMay 4).

Merryman, R.G., A study of temperature measurement. Precision in Debye - Scherrer specimens during high temperature $x$-ray diffraction measurement of thermal expansion, N64-21873.

Minzner, R.A., G. Savermann, and L.R. Peterson, A new method for atmospheric temperature determination, AD-427618.

Newcomb, T.P., Clutch temperatures, Automobile Eng. 54, 154 (April).

Penskii, F.l., Temperature measurements of internal combustion engine pistons, Measurement Techniques No. 7,610 (July).

Powe II, W.B., and T.W. Price, A me thod for the determination of local heat flux from transient temperature measurements, ISA Trans. 3, 246 ( July).

SterbutzeT, G.A. et al, A probe for the instantaneous measurement of surface temperature, RTD TDR63-4015; AD-431314; N64-21489.

Subbotin, V.I., M. Kh. Ibragimov, and E.V. Nomofelov, Statistical study of turbulent temperature pulsations in a liquid stream, High Temperature 2, 59 (Jan.-Feb.).

Tskhai, N.S., A method of determining the kinetic temperature of a gas Teplofizika Vysokikh Temperatur 2, 294 (March-April)

Whittaker, A.G., and D.C. Barham, Surfacetemperature measurements on burning solids J. Phys. Chem. 86, 196.

\section{5}

Auskern, A.B., and W.E. Thompson, Temperature indication during hot pressing, Am. Ceram. Soc. Bull. 44, 459.

Ballard, H.N., Rocke tsonde techniques for the measurement of temperature and wind in the stratosphere, ERDA-269; AD-458308; N65-22478.

Barrett, R.E., and H.R. Hazard, Problems in flue - gas temperature measurements, ASHRAE J. 7 , 88 ( Jan.).

Bates, J.J., Measurement of commutator temperature by a sliding-contact thermometer 
Proc. Inst. Elec. Eng. 112, 835 (April). Bernard, B., Flame temperature measurements, Instr. Control Systems 38, 113 (May).

Brunschwig, F.S., G.E. Kock, and J.K. wilhelm, Thermal sensor design for glide reentry vehicles, NASA Washington Symp. on Thermal Radiation of Solids, N6526911.

Cox, G.B., Effects of reduced pressures on passive temperature indicators (TempPlatesl, McDonnell Aircraft Corp., St. Louis, Mo., Rept. No. 051-065.73; AD460040

cutt, R.A., Proportional control steadies cryosurgical probe temperature, Control Eng. 12, 103 (Mar.).

Fateyev, A.V., A device for measuring the temperature of rotating bodies, Priborstronie 8, 26; N65-24155.

Fomin, Yu.Y.Y., and B.K. Gundorin, Measurement of rapidly changing temperatures of fuel at high pressures, Measurement Techniques 2, 152 (July).

Forgacs, R.L., B.A. Parafin, and E. Eichen, High voltage cathode temperature measurement, Rev. Sci. Instr. 36, 1198 (Aug.).

Gallagher, H.P., and B.D. Mallet, Liquid oxygen temperature instrumentation model $D M-18, A D-454062$.

Goldberger, R., Thermal probe speeds environmental testing, Electron. Ind. (Phila.) 24, 114 (May).

Gordov, A.N.' Peculiarities of the measurements of temperature under conditions of alternating heat emissions, Foreign Tech. Div., Air Force Systems Command, Wright-Patterson AFB, Ohio, FTD-TT-64-1076; AD-615431.

Gurevich, Ya.B., and A.P. Bashchenko, Measurement of the metal surface temperature in rolling, Measurement Techniques No. 11, 989 (April).

Hall, B.F. Jr., and N.F. Spooner, Temperature measurement in a graphite environment from $1600^{\circ}$ to $2500^{\circ} \mathrm{C}$, ISA Trans. 4, 355 (Oct.).

Keglin, B.G., and B.l. Khrapov, Measurement of temperature in a point of the surface during unsteady friction, Ind. Lab. 30, 1197 (Mar.).

Kiselev, V.M., Thermal probes for measuring the density of heat flows, FTD-TT64-1115; AD-614949.

Land, T., Probe pyrometer for glass, Ind. Process Heat 5,4 (Aug.).

Lieneweg, F., Temperature measurement; contact thermometers Part 1, Arch. Tech. Messen. No. 357, 237 (oct.).

Lutsker, 1. Sh., Device for the remote measurement of the temperature of rotating parts in a closed chamber, Ind. Lab. 31, 465 (Mar.).

Marlatt, W.E., The measurement of the surface temperature of the earth, NASACR-62117; N65-21425.

Mehrishi, J.N., and J.W. Lorimer, Temperature measurement in rotating-cylinder viscometers, J. Sci. Instr. 42, 173 (Mar.).
Merryman, R.G., and C.P. Kempter, Precise temperature measurement in Debye-Scherrer specimens at elevated temperatures, J. Am. Ceram. Soc. 48, 202.

Mikhailov, M.D., Measuring the temperature of flows with a pulsating velocity, Measurement Techniques, No. 5, 419 (May).

Parafin, B.A., and E. Eichen, High voltage cathode temperature measurement, Rev. Sci. Instr. 36, 1198 (Aug.).

Terrey, D.R., A contact pyrometer for the measurement of specimen temperatures on a thermobalance, J.Sci. Instr. 42, 507 $(J u \mid y)$.

Watson, G.G., Surface temperature measurement, Design Components Engineering No. 20,32 (Nov.).

We instein, I.,, and R.R. Howell, Technique for measuring high-temperature isotherm patterns on aerodynamically heated models with experimental results, NASA-TN-D2769; N65-23162.

\section{Nuclear Applications of Temperature}

1960

Lampe, D.A., Reactor cone thermal instrumentation, U.S. At. Energy Comm. Rept. TID 18103.

\section{2}

Brindley, J.H., Experimental calibration of surface attached thermocouples on a flat plte fuel element, Trans. Am. Nucl. Soc. $\underline{5}, 478$ (Nov.).

Brook, E.J., W.C. Kramer, and R.D. McGowan, High temperature sensors for BORAX-V bo i Iing fuel rods, U.S. At. Energy Comm. Rept. ANL6636 (OC†.).

Walstedt, R.E., Pulsed nuclear magnetic resonance thermometer, Problems of Low Temperature Physics and Thermodynamics Vol. 3. MacMillan Co., N.Y., 1962, p. 109.

\section{3}

Browning, W.E. Jr., Me thods of measuring temperature in nuclear reactors, Progr. Nuc!. Energy. Ser. I $v, 5,1$.

Budak, $\mathrm{H}_{\text {., Cl Cl}} 35$ isotope in $\mathrm{NaClO}_{3}$ as nuclear Q.R. Thermometer, Istanbul Univ. Fen. Fak. Mecmuasi, Seri $C, 28,142$ (July-oct.).

Conkling, D.R., and T.L. Rasmussen, Thermocouple attachment for the initial EOCR cone, U.S. At. Energy Comm. Rept. IDO16836 (Feb.).

DuBridge, R.A., In-core instrumentation development program. Detectors for in-core power monitoring, U.S. At. Energy Comm. Rept. GEAP-4222; NSA 30852.

Greenberg, H. J., Clamp on process tube temperature detector for monitoring nuclear reactor operation, Engelhard Inds. Tech. Bull. 4, 101 (Dec.).

Rainey, W.T. Jr., R.L. Bennett, and H.L. Hemphill, Measurement of temperature in reactor environments, U.S. At. Energy Comm. Rept. ONRL-3417. 
Terry, F.D., Effects of transient nuclear radiation on transducers and electrical cables, U.S. At. Energy Comm. Rept. IDO16914 (Nov. 30).

Nerva components irradiation program. Vol. 4, GTR test 7A, General Dynamics Corps., Fort worth, Texas, FZK-170-4; NSA 1914868 .

1964

Babbe, E.L., Increasing thermocouple reliability for in-pile experiments, Trans. Am. Nucl. Soc. 7, 55 (June).

Babbe, E.L., Development program to increase thermocouple reliability for inpile experiments, U.S. At. Energy Comm. Rept. TID 7697.

Bianchi, G., and S. Moretti, Behaviour of thermocouples under irradiations, Energie Nucleare 11, 426 (Aug.).

Bianchi, G., and $L$. Matteuzzi, Description of an apparatus for testing of $n$ - gamma irradiated thermocouples, U.S. At. Energy Comm. Rept. RT/IVG(54-1).

Bianchi, G., and L. Matteuzzi, Description of experiment for thermocouple irradiation tests, U.S. At. Energy Comm. Rept. $R T / \mid N G(54-2)$.

Breen, B.P., and G. Burnet, Peak heat flux in nucleate boiling heat transfer, U.S. At. Energy Comm. Rept. I5-810; N64-17740.

Briggs, N.H., E.L. Long, and F.R. MCQuilkin, Summary of experience with high temperature thermocouples used in the ORNL-GCR program fuel experiments, ORNLP-1055; NSA 19-20401.

Chapin, W.E., and E.N. Wyler, Transducers in nuclear environments, ISA J.11, 45 (Dec.).

Chappe |l, E.E. et al, Nerva components irradiation program. Vol. 3, GTR tes $t$ 13, General Dynamics Corp., Fort worth, Texas, FZK-184-3; NSA 19-13812.

Dal Iman, A.C., Mechanical reliability and thermoelectrical stability of noble metal thermocouples at $2600^{\circ} \mathrm{F}$ temperature and dose rates up to $10^{20}$ Nvt.

Davoine, F., R. Schley, and M. Villamayor, Les couples thermoelectriques D'alliages tungstene - rhenium, Commissariat a I'Energie Atomique. Centre d'Etudes Nucleaires, Saclay, CEA-R-2481; NSA 199438.

Elliot, M.N., and J.R. Grover, The measurement and control of gas temperature in the Fingal process, AERE-R-4512 (Dec.); N55-21943.

Fanciullo, S., Thermocouple development for the lithium cooled reactor experiment, U.S. At. Energy Comm. Rept. PWAC422 (Mar. 5).

Hawkins, R.C., Neutron flux monitors and thermocouples for in-core reactor measurements, At. Energy of Canada Ltd., Chalk River, ontario, AECL-2033.

HIuchan, S.A., Pressure and temperature transducers for high temperature and nuclear radiation environments, U.S. At. Energy Comm. Rept. Conf-658-1.

Krohova, M., and I. Saxl, Radiation sta- bility of thermocouples, U.S. At. Energy Comm. Rept. UJV-987.

McCarty, W.K., Thermocouple evaluation program, U.S. At. Energy Comm. Rept. NAASR-Memo- 9635 .

Tall nan, C.R., Cryogenic temperature measurement in a nuclear radiation environment, U.S. At. Energy Comm. Rept. LA-DC6549 .

Walters, C.T., and E.O. Fromm, Automatic reduction of long term irradiation capsul thermocouple data, U.S. At. Energy Comm. Rept. 7697.

Applications of ultra sonic energy: ultrasonic instrumentation for nuclear applications, Bimonthly progress Rept. No. 19, (oct. 1- Nov. 30), Aerojets, Inc., West Chester, Pa. NYO-2910-7 (Dec.); NSA 19-11478.

Periodic calibration of temperature sensing elements - reactor plant portion, U.S. A t. Energy Comm. Rept. WAPD-PWR-TE159.

Reactor instrumentation and control progress Rept. No. 85, General Electric Co., Cincinnat $i$, Ohio GEMP-85 (Nov. 30); NSA-19-10467.

\section{5}

Asphaug, B., Gamma thermometer development at HBWR, U.S. At. Energy Comm. Rept. HPR (Vol. 1) (Sec. 7).

Broks, E.J., Some in-vessel instrumentation programs representative of the Unite. States, Argonne Natl. Lab., l Jaho Falls, Idaho. CONF-640607(Vol. 1) (Paper A-14); NSA 19-24013.

Carroll, R.M., and P.E. Reagan, In-pile performance of $\mathrm{high}$ temperature thermocouples, Oak Ridge Nat1. Labs., Tenn. ORNL-P-1066; NSA 19-18344.

Eubank, H.P., Electron temperature measurements with atomic beams, Princeton Univ., N.J., Plasma Physics Lab., Rept. MATT-276 (June); N65-10598.

Falk, J., Instrumentation of the Swedish R2 - loop No. 2, Aktiebolaget Atomenergi, Stockholm, Sweden CONF-640607 (Vol. 1) (Paper B-3); NSA 19-24168.

Hawk ings, R.C., In-core instrumentation at C.R.N.L., At. Energy of Canada Ltd.., Chalk River, ontario CONF-640607 (VoI. 1) (Paper A-3); NSA 19-2407.

Kjaerheim, G.K., Central oxide temperature measurements, U.S. At. Energy Comm. Rept. (HPR-35 (Vol. 11) (Sec. 13)).

Kjaerheim, G.K., Measuring fuel rod center temperatures, Euro Nuclear 2,72 (Feb.).

Kuhlman, W.C., Evaluation of Fhermal neutron induced errors in the $W / W-25 \mathrm{Re}$ thermocouple, AlAA Propulsion Joint Special ist Conference, Colorado Springs, Colo., June 14-18, 1965, Paper 65-563.

Lupoli, P., G. Bianchi, and S. Morretti, Behaviour of irradiated thermocouples, experimental investigations, Comitato Nazionale per I'Energia Nucleare, Ispra (Italy) CONF-640607 (Vol. II) (Paper D4); NSA 19-24014.

Morretti, S., Behaviour of irradiated ther- 
mocouples. Theoretical investigations, Comitato Nazionale per 1 "Energia Nucleare, ispra (Italy) CONF-640607 (Vol. 2) (Paper D-5); NSA 19-22657.

Morrison, R.G., Application of miniature intrinsic thermocouples for reactor transient diagnostics, Los Alamos Scientific Lab., N. Mex., LA-3313-MS; N6527629; NSA 19-38236.

Prince, W.R., and W.L. Sibbitt, High temperature reactor core thermocouple experiments, Los Alamos Scientific Lab., N. Mex., LA-3336; N65-29244; NSA 1938237 .

McQuilkin, F.R., N.H. Briggs, and E.L. Long Jr., Summary of experience with high temperature thermocouples in the ORNL-GCR program, fuel-irradiation experiments, Trans. Am. Nucl. Soc. 8 , 69 (May).

Rolstad, E., Thermocouples, cables and tubes for in core instruments at HBWR, U.S. At. Energy Comm. Rept., HPR- 35 (Vol. 2) (Sec. 10).

Stentz, R.H., and R.L. Treinen, Development of nuclear sensors, Final report, General Electric Co., Cincinnati, Ohio, GEMP-90; NSA 19-38091.

Subbotin, V.l et al, Small scale thermocouples for measuring temperature in the reactor of the first atomic power station, Teploenergetika No. 5, 91 (May).

Walstedt, R.E. et al, Nuclear spin thermometry below $1{ }^{\circ} \mathrm{K}$, Proc. Roy. Soc.

(London) 284A, 499.

Component development, Oak Ridge Natl. Lab., Tenn., ORNL - 3812; NSA 19-35772.

High temperature materials and reactor component development programs. Fourth Annual Rept. Vol. 1, Materials, General Electric Co., Cincinnati, Ohio, GEMP334A: NSA 19-24916.

High temperature materials and reactor component development programs. Vol. 3, Instrumentation and controls, Gen. Elec. Co., Cincinnatt $i$, Ohio, GEMP-334C; NSA 19-25639.

High temperature materials program Progress Rept. No. 43, Part A, Oct. 15-Dec. 15 , 1964, General Electric Co., Cincinnati, Ohio, GEMP-43A; N65-30592.

High temperature materials program, Progress Rept. No. 49, Part A, Gen. Elec. Co., Cincinnati, Ohio, GEMP-49A; N6530592 .

Process instrumentation development, Oak Ridge Natl. Lab., Tenn., ORNL-3782; NSA19-42690.

Reactor instrumentation and control. Progress Rept. No. 87, Gen. Elec. Co., Cincinnati, Ohio, GEMP-87; NSA 19-24016.

Reactor instrumentation and control, Progress Rept. No. 88, Gen. Elec. Co., Cincinnati, Ohio, GEMP-88; NSA 19-38090.

10. Associated Equipment and Testing Procedure

1961

Houke, H.F., Study of high-current resis- tance testing of grounded shielded Chromel-Alumel thermocouples, AD- 459284.

Nordberg, W., and W.G. Stroud, Results of IGY rocket-grenade experiments to measure temperatures and winds above the island of Guam, J. Geophys. Res. 60, (Feb.); Intern. Geophys. Year WorTd Data Center A. Washington, D.C. A third compilation of U.S. IGY-IGC Rocket Program Results, April 1963, p.23; N63-19678.

Schlegel, E.S., Apparatus for determining temperature profiles in microstructures, Rev. Sci. Instr. 34, 360 (April).

\section{2}

Bulychev, V.S., Automatic indication of broken thermocouples in potentiometer EPP-09, Measurement Techniques No. 2, 125 (July).

Gehrmann, E., and I. Schusta, Method for the determination of the time constant of thermocouples, wiss Z. Hochsch. Elektrotech. I Imenau. $8,419$.

Lehmann, K., and K. Schme iser, New temperature measuring equipment for rotatable furnaces, Elektrotech. Z. 14B, 462 lAug. 20).

Pak, V., and Yu. P. Krinskii, Automatic equipment for calibrating platinum platinorhodium thermocouples, Measurement Techniques No. 1, 38 (June).

Rahlfs, P., Testing contact thermometers, Arch. Tech. Messen. No. 323, 279 (Dec.).

\section{3}

Brown, D.L. et al, Instrumentation and recording equipment used in conjunction with the ARL twenty-inch hypersonic wind tunnel, Wright Patterson AFB, Ohio, Aeron Res. Lab., Rept. ARL 63-162 (Sept.).

cameron, G., and R. L. Blanchard, Performance and use of metal freezing-point cells which generate precise temperature, ISA Trans. 2, 224 (July).

Cox, C.D., and W.D. Edwards, l ce point maintained thermoelectrically and regulated by change of state, Rev. Sci. Instr. 34, 704 (June).

Dengler, C.O., A new mercury freezing point cell, ISA Trans. 2, 298 (OCt.); Instr. Control Systems $3 \overline{6}, 119$ (Dec.).

Dengler, C.O., A freezing apparatus for the triple point of water cell, Proc. Instr. Soc. Am. 18, Paper No. 57.4.63.

Foord, T. R., R. C. Langlands, and A. J. Binnie, Transformer-ratio bridge network with precise lead compensation and its aplication to the measurement of temperature and temperature difference, Proc. Inst. Elec. Engrs. 110, 1693 (Sept.).

Foster, R.B. Jr., An a ir-bath comparator for I iquid-in-glass thermometers, U.S. A t. Energy Comm. Rept. SCTM-21-63 (24) $(\mathrm{Feb})$.

$\mathrm{Hill,J.J.,}$, and A.P. Miller, $A$ n AC double bridge with inductively coupled ratio arms for precision platinum-resistance thermometry, Proc. Inst. Elec. Engrs. 110, 419 (Feb.).

I sakov, M.N., Measurement of atmospheric 
temperature by means of satellite-borne equipment, Kosmicheskie issledovaniia, 1, 159 (July - Aug.).

Joh̄n, R.E., Temperature distribution and thermal efficiency of low power archeated plasma jets, Brit. J.Appl. Phys. 14,585 (Sept.).

Jones, T.P., The suitability of tungsten strip lamps as secondary standard sources in photoelectric pyrometry, J. Sci. Instr. 40, 101 (March).

Kayander, M.S., Radiator with large sighting coefficient for calibrating radiation pyrometers, Measurement Techniques No. 10,850 (June).

Margulis, O.M. et al, Refractory insulation for thermal electrodes used for measuring high temperatures, Measurement Techniques No. 6, 480 (Nov.).

McDonough, R., and H.A. Hawthorne, An inexpensive resistance welder for thermocouple fabrication, U.S. At. Energy

Comm. Rept. TID 19268.

Meiran, S., Tester checks out thermocouple circuits, Electronics 36, 102 (Mar. 15).

Metzler, A.J., and J.R. Branstetter, Fast response blackbody furnace for temperatures up to $3000^{\circ} \mathrm{R}$, Rev. Sci. Instr. 34, 1216 (Nov.).

Murdock, J.W., C.J. Foltz, and C. Gregory, A practical method of determining response time of thermometers in I iquid baths, Trans. ASME (J.Eng. for Power) $85 \mathrm{~A}, 27$.

Pak, V., Yu. P. Krinski $i$, and I.S. Belyaeva, Simplified equipment for calibrating precious metal thermocouples in a dynamic condition, Measurement Techniques No. 11, 928 (June).

Rotbert, I.L., and N.P. Udalov, Temperature transmitters incorporating semiconductor diodes and transistors, Instr. Construct. No. 10, 1 (oct.).

Russell, A., An inexpensive thermocouplescanner using gold-plated relays, Control 7,132 (sept.).

Sata, $T^{-}$, and R. Kiyoura, Studies on the tungsten furnace and its temperature measurement by W-WRe thermocouple up to $2700^{\circ} \mathrm{C}$, Tokyo Inst. Technol. Bull. No. 53.

Savage, B., A multipoint thermocouple reference junction, J. Sci. Instr. 40, 45 $($ Jan.).

Silverman, L., Reference junctions, Instr. Control systems 36, 107 (June).

Tao, Li-ten, Automatic potentiometer circuits with temperature compensations for thermocouples, Instr. Construct. No. 8 , 9 ( Aug.).

vanvor, $H_{\text {. }}$, Testing and standardization of apparatus to measure temperatures. Resistance thermometers and thermocouples, Intern. Elektrowaerme - Kongr., 5., Wiesbaden, Ger. 1963, 625 .

Voitenko, A.E., F.O. Kuznetsov, and I.S. Model, The use of an IFK-50 lamp as a high-intensity, pulsed standard source, Instr. Exp. Tech. No. 6, 1184 (July).

We iner, S., and F. Schwartz, Thermopile IR detectors, Space/Aeronautics 40, 95
( Aug.)

A useful temperature duration recorder R\&D No. 18,42 (Feb.).

Automatic thermocouple comparator, Nat 1. Bur. Std. (U.S.) Tech. News Bull. 47, 82 (May).

\section{4}

As theimer, R.W., and S. Weiner, Solidbacked evaporated thermopile radiation detectors, Appl. Optics 3, 493 (April).

Barber, C.R. et al, A full-radiator lamp designed to replace the tungsten strip lamp as a pyrometric standard, Nature 202, 686 (May 16).

Brouwer, G.P., A highly sensitive recording electronic pyrometer, Philips Res. Rept. 19, 471 (Oct.).

Buynyachenko, G.P., Multi-range potenitometer bridge, N64-13581.

Ebinger, A., and G. Siegfried, Potentiometer for thermoelectric voltages with elec tronic stabilized auxiliary current source Z. Instrumentenk. 72, 103 (April).

El Agib, A.A.R., A hydraulic bridge for measuring small temperature difference, J. Sci. Instr. 41, 596 (Oct.).

Gel fond, L., Evaluation of the model PRAIC thermocouple reference junction, Rocketdyne, Canoga Park, Calif., Rept. No. TR64-7; AD-470 583.

Goldberg, J.L., and H.M. King, Automat ic switching of sensitive thermocouples, Electron. Eng. 36, 591 (Sept.).

Grote, H.H., Improvement of sensor response by an analog technique, Army Signal Research and Development Agency and Lab., Fort Monmouth, N.J. USAELRDL-2445; N6426507; AD-600 141 .

King, J., The design of a temperature-compensated thermocouple reference circuit, AD- 600675 .

Knowlson, P.M., and P.M. Bartle, Sealing a stainless-steel-sheated thermocouple into a Magnox end cap, J. Inst. Metals 93,52 (OCt.).

Kozhukh, V. Ya., Computation of thermistor bridge circuits for automatic measurements of temperature difference, Measurement Techniques No. 7, 601 (July).

Lancia, F.M., and J.D. McGervey, Apparatus for measurements of Peltier coefficients, Rev. Sci. Instr. 35, 1302 (Oct.).

Levi, L.I., E.A. Chernin, and A.l. Degaltsev, Device for determining the dynamic properties of immersion thermocouples, Ind. Lab. 29, 1674 (June).

Meyer, $H_{.}$, and $E$. Wilde, Thermoelement lead for high vacuum devices and which can be thoroughly heated, Exp. Tech. Physik 12,

Pak, $V_{.}$, and Yu. P. Krinski $i$, Automatic testing of commercial thermocouples made of non-precious metals, Measurement Techniques No. 5, 391 (Nov.).

Ruff, A.W. Jr., Open-probe thermocouple control of radio-frequency heating, Rev. Sci. Instr. 35, 760 (June).

Schechowzow, A.F., Pneumatic contact device for measuring piston temperature in a running motor, Feinwerk Technik 63, 
$18($ Jan.)

Schmitz, L.S., Nonlinear analog ne twork to convert surface temperature to heat flux, N64-18176.

Shcherbina, D.M., Application of a Kerr cell for comparing luminous fluxes, Measurement Techniques No. 1, 41 (July).

Shcherbina, D.M., Supplies for standard temperatature lamps from rectifiers, Measurement Techniques No. 8, 620 (Feb.).

Shimanskiy, Yu. N. et al, A device for high-speed recording of small temperature drops, N64-29149.

Skuratov, S.M., and M.N. Goroshko, Simple bridge circuit for measuring the resistance of a platinum resistance thermometer, Measurement Techniques No.2, 104 (Aug.).

Thomson, J.H., Development of an improved time-temperature integrator, AD-434147.

Zhinkin, B.N., Electrical oven for testing thermocouples, Measuremen ${ }^{\dagger}$ Techniques No. 1,45 (July).

A new temperature measuring apparatus for laboratory purposes, Arch. Tech. Messen. No. 344, 209 (Sept.).

Automatic thermocouple comparator, Instr. Control Systems 37, 91 (May).

Digital thermometer covers wide range, Electronics 37, 113 (May 4 ).

\section{5}

Boom, G., and $F$. van der Woude, Very stable and simple compensator for thermocouples, Rev. Sci. Instr. 36, 857 (June). Caldwell, F.R., Temperatures of thermocouple reference junctions in an ice bath, J. Res. Natl. Bur. Std. (U.S.) 69C, 95 (April).

Claggett, T.J., External thermocouple compensation, Instrumentation 18, 24.

Dengler, C.O., Frezing apparafus for the triple-point-of-water cell, Instr. Control Systems 38, 117 (May).

Feldman, C.L., Automatic ice-point thermocouple reference junction, instr. Control Systems 38, 101 (Jan.).

Greenwood, T.L., Thermocouple-continuity monitor, ISA J. 12, 88 (Feb.).

Hobson, D.L., and $\bar{B}$. Cohen, Temperature measuring test set, Ind. Electron. $\overline{3}$, 117 (March).

Ichiye, T., and N.B. Plutchak, Calibration and field test of IRT, Lamont Geological Observatory, Pal isades, N.Y. Rept. No. CU-12-65 Nonr-26648; AD-470 136.

Kochan, V.A. et al, Automatic recording instrument for measuring low temperatures, Measurement Techniques No. 1, 52 (June).

Kol'tsov, A.A., and G. Kh. Valeyeva, Analys is of one measuring circuit for automatic electronic potentiometers measuring temperature, N65-24157.

Miksch, E.S., Equilibrium of the ice-water temperature standard, Rev. Sci. Instr. 36,797 (June).

Pak, V., Bridge method for comparing precious metal thermocouples, Measuremen $t$ Techniques No. 2, 149 (Feb.).
Perrey, H.E., Amplifier for temperature sensors, ISA J. 12, 67 (Jan.).

Schrenker, H., Automatic, electronic compensators in submerged pyrometric installations, Arch. Tech. Messen. No. 358, R142 (Nov.).

Schwarzer, H., Electrical temperature measurement and equipment, Arch. Tech. Messen. No. 356, 197 (Sept.).

Sereznov, A.N., Me thod for reducing the noise level at the input of an instrument used in measuring temperature with thermocouples, Measurement Techniques No.6, 503 (June).

Sharpe, J., An application of photomultiplier tubes in temperature measurement, Ind. Electron. 3, $471(0 \mathrm{ct})$.

Stansbury, E.E. $e^{\bar{f}}$ al, Modified dauphinee thermocouple comparator circituit for adiabatic calorimetry, Rev. Sci. Instr. 36, 480 (April).

\section{General}

\section{2}

Kirk, F.W., and N.R. Rimboi, Instrumentation, Am. Tech. Soc., Chicago, 111 .

Ohring, G., W. Tang, and $Y$. DeSanto, Theoretical estimates of the average surface temperature on Mars, J. Atmospheric Sci. 19, 444 (Nov.).

Slaughter, J.I., and J.L. Margrave, Temperature measurement, Aerospace Corp., Los Angeles, Calif. Rept. No. TDR-169 (324020) TN-1 (Oct.); AD- 298142.

Temperature of Venus, Instr. Pract. 16, 1494 (Dec.).

\section{3}

Agabohov, S.G., and A. Komarek, Blackness of platinum and platinum-rhodium wires, Inzh. Fiz. Zh. $\underline{6}, 79$.

Ambrok, G.S., A.N. Gordov, and A.G. I vanova, Method of determining the thermal inertia of some types of temperature measuring devices, High Temperature 1, 413 (Nov.Dec.l.

Benedict, R.P., Temperature and its measurement, Electro-Technol. (New York) 72, 71 (July).

Benedict, R.P., Temperature measurement in moving fluids, Electro-Technol. (New York) 72,56 (oct.).

Billing, B.F., Thermocouples, a critical survey, Royal Aircraft Establishment, Farnborough, England, RAE-TN-CPM-18(May); N65-20747.

Bodea, E., Rationalizing the kinetic definition of temperature, Acta Phys. Austriaca 16, 80 .

Cook, N.H., and E. Rabinowicz, Physical measurement and analys is, Addison-Wesley Publishing Co., Reading, Mass.

Corruccini, R.J., Temperature measurements in cryogenic engineering, Advan. Cryog. Eng. $\underline{8}, 315$.

Fruchtmán, I., Temperature measurements of hot gas streams AlAA J. 11909 (Aug.).

George, A.L. et al, Converśsion formula for 
thermocouples, Instr. Control Systems 36,133 (July).

Gershenzon, S.S., and K.N. Manuylov, On the rate of detecting temperature gradient changes by measuring instruments, Foreign Tech. Div., Air Force Systems Command, FTD-TT 63 540; AD 415007.

Graziano, E.E.., Experimental measurements of velocity and temperature profiles and skin-friction in supersonic turbulent compressible flow: an annotated bibliography, N63-23615.

Hertzfeld, C.M., ed. in chief, Temperature, its measurement and control in science and industry. Volume 3, part 3 , Biology and medicine, J.D. Hardy, ed., Rheinhold Pub. Corp., N.Y.

Kos tkowski, H.J., and G.W. Burns, Thermocouple and radiation thermometry above $900^{\circ} \mathrm{K}$, NASA Measurement of thermal radiation properties of solids, p. 13.

Kurti, N., Temperatures below $10^{\circ} \mathrm{K}$, Advan. Cryog. Eng. 8,1 .

Malone, E.W., Surface temperature measurement errors, Trans. Inst. Elect. Electron. Engrs. AS-1 15 (Feb.).

Marcus, H., Present and future requirements for high temperature measurements, NASA Measurement of thermal radiation properties of solids, p. 434.

Sokeland, W.P. et al, A typical problem in heat transfer: determine the steadystate axial temperature distribution in a conical thermocouple support, Eng. J. (Montreal) 10, No. 2, 42.

Sokeland, W.P. and J.A. Payne, Solution to the previous problem: determine the steady-state axial temperature distribution in a conical thermocouple support, Eng. J. (Montreal) 10, No. 4, 50.

Stimson, H.F., J.F. Swindelis, and R. E. Wilson, Temperature scales, thermocouples and resistance thermometers, Am. Inst. Phys. Handb. Second ed. Sec. 4a, pp. 2-21.

stotzek, H., Thermal measurement systems and their construction from individual measuring instruments, Arch. Tech. Messen No. 331, 181 (Aug.).

Timmerhaus, K.D., Measurement of low temperatures, Cryogenic Engineering, John Wiley \& Sons, N.Y. P. 196.

Some developments in techniques for temperature measurement, Proc. of a Symposium (Apri) 26, 1962) Inst. Mech. Engrs. (London) 1963.

\section{4}

Barber, C.R., Temperature scale measurement techniques for the range 10 to $90^{\circ}-$ $\mathrm{K}$, Acta Imeko p. 415, Paper No. 23-UK246 .

Barber, C.R., Tempperature scale of the National Physical Laboratory in the range $10-90^{\circ} \mathrm{K}$, Comite Consultatif Thermometrie, Comite Intern. Poids Mesures, 6e, Sevres, France 1962, 19 (Pub. 1964).

Barber, C.R., Conference on the measurement of high temperatures, London May 1964, Brit.J.Appl. Phys.15, 1003 $\left(\operatorname{sep} t^{\dagger}\right)$.

Baver, $W_{.}$, and R. Buschner, Report on measurement of the air temperature with various types of radiation shielding, N6416484 .

Bollinger, L.E., Transducers for measurement. Part 3 Temperature from one extreme to the other, ISA J. 11, 73 (OCt.).

Conison, J., Process temperature measurement, Instr. Control Systems 37, 141 (June).

Coombe, R.A., Measuring temperatures in the range $1000^{\circ} \mathrm{C}$ to $5000^{\circ} \mathrm{C}$, Part 2, R\&D No. 29, 14 (Jan.).

Diamond, J.J. ed., Bibliography on the high temperature chemistry and physics of materials in the condensed state, International Union of Pure and Applied Chemistry 1964, No. 4 (Oct. - Dec.).

Grey, J., Thermodynamic methods of high temperature measurement, ISA Trans. 4 , 102 (Apr. - June).

Hall, W.M., The application of temperature rate measurements to the determination of thermal emittance, N64-20604.

Hammond, C.M., and D.L. Burk, A simplified thermal analys is technique for measuring transformation temperatures of steel, Mater. Res. Std. 4, 275 (June).

Hoffman, E.E.. Potadssssium corrosion test loop development Quarterly Progress Rept. No. 5 (July 15, 1964-oct. 15, 1964) General Electric Co., Cincinnati, Onio, NASA CR-54269; NSA 19-20473.

Holbeche, T.A., and D.A. Spence, $A$ theore$t i c a l$ and experimental investigation of temperature variation behind attenuating shock waves, Proc. Roy. Soc. (London) A279, 111 (May 12 ).

Hunt, L.B., The early history of the thermocouple, Platinum metals Rev. 8,23 (Jan.).

Ito, T., and T. Morikawa, The methods of the measurement of temperature and electron density of arc plasma, Mitsubishi Denk i Giho 38, 8 (Dec.).

Kirenkov, 1.1., Basic metrological problems in temperature measurements, Measurement Techniques No. 12, 1009 (June).

Koch, H., Application of temperature measuring methods in flow technology, Arch. Tech. Messen No. 340, 97 (May).

Landensperger, $W_{.}$, and $D$. Stark, The total optical emissivity of rhenium, rhodium, palladium, and titanium, Z. Physik 180, 178 .

Lapworth, K.C., Investigation of the Physical properties of gases at high temperatures, J. Roy. Aeronaut. Soc. 68, 185 (Mar.).

Lehmberg, A.E., Calculation of temperature sensor error introduced by frictional heating, $A D-48866$.

Lieneweg, F., Indication delay of thermometers, Arch. Tech. Messen No. 340, R46 (May).

Louis, J.R., and W.E. Hartman, The determination and compensation of temperature sensor transfer functions, ASME Winter Annual Meting, New York, Nov. 29-Dec. 4, Paper 64-WA/AUT-13. 
Miller, J.T., Revised course in industrial instrument technology. Chapter 9, Electrical thermometers, Instr. Pract. 18,41 ( Jan.).

Rozenshtok, Yu. L., Statistical characteristics of the temperature measurement procedure for a uniform steady-state turbulent flow, Inzh. Fiz. Zh. I, 87 (Feb.).

Shashkov, A.G., Block diagrams for measuring flow parameters by means of thermistors, Inzh. Fiz. Zh. 9, 87 (Sept.).

Shu, H. H. H., E. W. Gaylord, and W. F. Hughes, Relation between the rubbing interface temperature distribution and dynamic thermocouple temperatures, Trans. ASME 086, 417 (Sept.).

Sklarew, S., The problem of accurately measuring changing temperatures of nonmetallic surfaces, Am. Soc. Metals 2 , 235.

Slaughter, J.l., and J.L. Margrave, Temperature measurement, $\mathrm{AD}-448346$.

Smetanina, L.I., The dynamic method of measuring high temperature, High Temperature 2 , 80 ( Jan.).

Soviani, R., A new way of determining the thermal inertia of temperature transducers, Acta Imeko 1964, 369. Paper No.. 23-RU-226.

Stepanov, G.P., and Yu. N. Kulikov, Investigation of dynamic characteristics of temperature sensors for a retarded air flow, N64-25590.

Strutter, E., and G. Luck, on the measurement of time constants of thermocouples, Jena Rev. No. 9, 210.

Tar takovskii, D.F., Computation of the thermal inertia of commercial thermal detectors Measurement Techniques No. 11 , 922 (Apr.).

Tereshchenko, A.F., on the method of measuring surface temperature, Ind. Lab. $30,422($ oct.).

vanvor, H., Temperature measurement in the laboratory, Glas-Instr. Tech. 8 , 171 .

Vrolyk, J.J., and P.A. Kinzie, Feasability investigation of heat-flowrote measuring techniques, Final Rept. ( Jan.) RTD-TDR-63-4077; AD-431189; N65-22074.

Walker, R.F., High temperature measurements and standards $100^{\circ}-30^{\circ}$, High temperature technology; International union of pure and applied chemistry, Commission on high temperatures and refractories, International symposium, Pacific Grove, Cal if.., 'Sept. 8-11, 1963, Proceedings, Butterworth and Co. (Publishersl, Ltd., London $p .7$.

Zysk, E.D., Noble metals in thermometryrecent developments, Engelhard Inds. Tech. Bull. 5, 69 (Dec.).

Evaluation of temperature probes, $A D-442$ 102 .

Guide posts to keep thermocouple users out of hot water, S.A.E. J. 72, 82(Aug.)

High temperature materials program progress rept. No. 41, Part A, Nov. 30 , General Electric Co., Cincinnati, Ohio, GEMP-41A; NSA 19-11669.
Mass flow by temperature measurement, I nstr. Control Systems 37, 95 (Mar.).

\section{5}

Angerhofer, A.W., Cryogenic instrumentation, 1Sensing temperature and level, Control Eng. 12, 67 (oct.).

Atkins, $\vec{R} \cdot M .$, Advances in thermal instrumentation, Ind. Research 7,84 (June).

Barber, J.A., Measurements of high temperatures, U.S. At. Energy Comm., Sandia Corp., A lbuquer que, N.M. CONF-650204-7; SC-DC65-1237; NSA 19-30489.

Bliss, P., and S. Fanciullo, High temperature thermometry at Pratt and Whitney a ircraft-canel, Pratt and Whitney Aircraft, Middle town, Conn. PWAC-462; N65-24955.

Field, R.T., Temperature sensors, N65-31353.

Harris, H., Comparing the three most popular temperature sensors, Electron. Design 13, 62 ( Jan.).

Jasicki, Z., and A. Handke, Some problems concerning temperature measurement of a hot gas stream, Pomiary, Automat. Kontrola 11,340 (Aug.).

Johansson, J., Cryogenic measurements, Instr. Control Systems 38, 107 (May).

Kennedy, R.H., Sensing and measuring temperature in manufacturing environments, Automation $12,78(0 \mathrm{ct}$.$) .$

Lieneweg, F., VDE/VDI 3511 Guide "Technical temperature measurement," Arch. Tech. Messen No. 350, 49 (Mar.).

McCoy, J.G., An improved me thod for the reduction of rocketsonde temperature data, Army Electronics Research and Development Activity, White Sands Missile Range, N.M. ERDA-279; AD-458 318; N65-19556.

ogale, V.A., Temperature measurements at $\mathrm{high}$ temperatures and high speeds- a literature survey, N65-35056.

oshima, K., Low temperature work in Japan, Cryogenics 5,1 (Feb.).

Rozenshtok, Yü.L., Dynamic characteristics of a stationary linear system for measuring temperature, Measurement Techniques No. 3, 240 (Aug.).

Rozenshtok, Yu.L., Dispersion and accidental error of measurement of temperature of locally turbulent flow, N65-30420.

Schwarzer, H., The electrical measurement of temperature and measurement systems, Arch. Tech. Messen No. 356, 197 (Sept.).

Segletes, T., A bibliography of aerothermal sensing techniques, Martin Co., Baltimore, Md. Rept. No. ER-13687; AD-464 119.

Smith, C., Temperature sénsing elements, Product Des. Eng. 3, 74 (Sept.).

Yaryshev, N.A., Heatzexchange formula for thermometers which takes into account heat removal and radiation, Measurement Techniques No. 5, 411 (May).

Methods of high-temperature measurement of gases: compilation of abstracts, Aerospace Technology Div., Library of Congress Rept. ATD-P-65-53; AD-618 532. 

Bibliography of Temperature Measurement

January 1966 to December 1969

Paul D. Freeze and Leslie P. Parker 

Approximately 1800 references to the literature of temperature measurement are presented in this supplement to NBS Monograph 27, Bibliography of Temperature Measurement. The monograph, issued April 6, 1961, covered the period January 1953 to June 1960. Supplement 1, issued September 13, 1963, covered the period July 1960 to December 1962. Supplement 2, issued April 28, 1967, covered the period January 1963 to December 1965. This supplement covers essentially the period from January 1966 to December 1969, but some earlier references omitted from the previous bibliographies have been included. In general, the arrangement of material is the same as in Monograph 27; Part 1 has, however, been changed in the supplement to include theory, calibration, and temperature scales.

Key words: Fluidic thermometers; pyrometry; radiation pyrometry; temperature measurement; thermistors; thermocouple; thermometry

\section{INTRODUCTION}

Research and development for the improvement of temperature measurement capabilities are very active as is evidenced by the growth of the literature of the field. Advances in technology and in scientific research bring with them new problems and new requirements that call for new or improved methods for measuring the temperatures that are an important factor, frequently a critical factor, in most physical systems. Research and development efforts are being directed to the development of temperature measuring instruments that are more accurate, more rugged, more versatile, and generally more reliable, to extend measuring capabilities to high and low temperature extremes, to deal with difficult application situations, to improve theoretical understanding of temperature and related phenomena, and to interpret temperature measurement data.

Surveillance of the literature of temperature measurement is maintained by NBS as a necessary support for its many programs in which temperature measurement plays an important role. Since the need of the NBS for this information is shared by the scientific and technological communities, the information gathered in this surveillance is published as a contribution to the advance of measurement capabilities. The usefulness of the bibliography on temperature measurement is witnessed by the continuing demand for Monograph 27 and its supplements and by support for the work voiced by interested organizations such as the AE-2 Subcommittee on Engine Temperature Sensing of the Society of Automotive Engineers.

The references were collected from scientific and technical journals and from government reports of investigations sponsored or conducted by various governmental agencies. English, German, and French journals and English translations of Russian journals were covered as well as the major abstract journals. Some references to material in languages other than English, obtained from the abstract journals, are included. To obtain references to government reports the following were consulted: Technical Abstract Bulletin and the computerized bibliographic facility of the Defense Documentation Center (formerly Armed Services Technical Information Agency); Scientific and Technical Aerospace Reports, National Aeronautics and Space Administration (NASA); Nuclear Science Abstracts, United States Atomic Energy Commission; and U. S. Government Research Reports, National Technical Information Service, U. S. Department of Commerce. While reasonably complete coverage was intended, it is inevitable that oversights and other unintentional omissions have occurred.

The topical subdivisions are shown in the table of contents. Within each subdivision material is arranged chronologically in sections by year of issue. Within these chronological sections, references are arranged alphabetically by author. "Anonymous" articles appear at the end of each section.

The period covered is from January 1966 to December 1969, but some earlier entries that had been overlooked in NBS Monograph 27 - Supplement 2 have been included.

The journal abbreviations used are those employed in Chemical Abstracts, 1961 through 1967. Volume numbers are underlined and date of issue is given where page numbers do not run consecutively throughout a given volume. Since the year of issue appears at the head of each chronological section, this is not repeated in the individual references.

Numbers prefixed by the letters $A D$ refer to report numbers in the Technical Abstract Bulletin; those by $\mathrm{N} 66, \mathrm{~N} 67, \mathrm{~N} 68$, and $\mathrm{N} 69$ are identifying numbers in the Scientific and Technical Aerospace Re- 
ports, and those by NSA refer to the report numbers in the Nuclear Sclence Abstracts. Those numbers prefixed by the letter A refer to publications abstracted in International Aerospace Abstracts. The complete report can be obtained from the Technical Information Service, American Institute of Aeronautics and Astronautics, Inc., 750 Third Ave, New York, N,Y., 20017. Other publications not so cataloged can often be obtained from the Clearing House for Federal Scientific and Technical Information (Referenced CFSTI), now known as (National Technical Information Service, 5285 Port Royal Road, Springfield, Va., 22151. 


\section{Theory, Calibration and \\ Temperature Scales}

\section{4}

Tskhai, N. S., Method for the determination of the kinetic temperature of a gas, High Temp. 2, No. 2, 261 (Mar.-Apr.).

\section{5}

Evans, J. P., The realization and use of the international practical temperature scale of 1948, Proc, Instr. Soc. Am. 20, Part I, Paper. No. 14, 3-1-65.

Gordov, A. N., Measurement of variable temperatures, Tr. Inst. Gos. Kom., Standartov, Mer i Izmeritel'n Priborov SSSR, No. 76, 115.

Kirenkov, I. I., Development of a thermodynamic temperature scale, Tr. Inst. Gos. Kom., Standartov, Mer i I zmeritel'n Priborov SSSR, No. 76,102 .

Marciniak, H., Heterogeneity of iron-constantan thermocouples and its effect upon the accuracy of temperature measurement, Pomiary, Automat. Kont. 11, No. 5, 207.

Roder, H. M., Irregularities in the NBS (1955) provisional temperature scale, J. Res. Nat. Bur. Stand. 69A, 527, (Nov.).

Schoenig, F. C., and J. A. Kadlecek, Reference tables: Thermocouple emf vs, temperature for tungsten -3 percent rhenium vs. tungsten-25 percent rhenium thermocouples, Knolls Atomic Power Lab., Schenectady, N. Y., KAPL-M-6498; NSA 20-13028.

\section{6}

Aitken, G. W., Temperature-millivolt conversion table; copper-constantan thermocouples, 32F . reference temperature, Cold Regions Research and Engineering Lab., Hanover, N. H., Special Report No. CRREL-SR-108, Task: DA-IV025001A13001; $A D-805751$ (Aug.).

Barber, C. R., and J. G. Hayes, The derivation of the provisional reference table CCT64, $T=f(W)$ for platinum resistance thermometers for the range 12 to $273.15^{\circ} \mathrm{K}$. Part II. The derivation of the table for the range from 90 to $273.15^{\circ} \mathrm{K}$, Metrologia 2, No. 1, 11 (Jan.).

Crovini, L., and S. Sartori, Some measurements of the international practical temperature scale, Ric. Sci. 36, No. 3, 171 (Mar.).

Butkiewicz, J., Calibration system for thermometric instruments in the range 2000 to $3000^{\circ}$, Pomiary, Automat. Kónt. 12, No. 4, 123 (Apri1).

Cataland, G., and H. H. Plumb, Calibration of germanium resistors at Low temperatures (2-20 Kelvin), J. Res. Nat. Bur. Stand, 70A, 243 (May - June).
Collins, F., and E. R. Brownscombe, The temperature scale, Nature 211, 956 (Aug. 27).

Fayans, A. Kh. Hardening points of cadmium and $t$ in as a constant point of IPTS (International Practical Temperature Scale) Tr. Inst. Gos. Kom. Standartov, Mer i Izmeritel'n Priborov SSSR No. 87,32 .

Fischer, S., Temperature measurement by means of thermodynamic temperature-measuring apparatus, Wiss. Z. Tech., Univ. Dresden, 15, No. 1, 89.

Gaggioli, R. A., and J. W. Mitche11, Thermocouple corrections from irreversibility theory, An. J. Phys, 34, No. 7, 549, N66-26311; AD-630750 (July).

Georgian, J. C., The MKS temperature scale, J. Chem. Educ. 43, No. 8, 414 (Aug.)

Hall, J. A., The radiation measurements of the freezing point of gold, Metrologia 2, 166 (Oct.).

Kantor, P. B., et al, Melting point of corundum as a secondary reference point on the temperature scale, Meas. Tech. (USSR), No. 5, 615 (May).

Kremer, M. L., Ideal gas equation and temperature scale, J. Chem. Educ. 43, No. 11, 583.

Mann, E., et al, Effect of lattice defects on the electric resistivity and thermoelectric power of metals, Z. Physik 193, No. 2, 295.

Orlova, M. P., and D. N. Astrov, Thermodynamic temperature scale for the range from 4.2 to $20^{\circ} \mathrm{K}$, Com. Consult. Thermom., Com. Int. Poids Mes., Sess. 7th Paris, 1964, 109 (Publ. 1966).

Orlova, M. P., et al, A new determination of the normal oxygen boiling temperature, Metrologia 2, 162 (Oct.).

Orlova, M. P., et al, the derivation of the provisional reference table CCT $64, T=f(W)$ for platinum resistance thermometers for the range from 12 to $273.15^{\circ} \mathrm{K}$. Part I. The derivation of the table for the range 12 to $95^{\circ} \mathrm{K}$, Metrologia 2, No. 1, 6 (Jan.).

Plumb, H., and G. Cataland, Acoustical thermometer and the National Bureau of Standards provisional temperature scale 2-20 (1965), Metrologia 2, 127 (Oct.).

Popov, V. H., Distortions of the temperature field in the region of a thermocouple seal, Teplofiz, Vys. Temp. 4, 261 (Mar.-Apr.).

Sambongi, T., and I. Maeda, An empirical formula for the helium 4 vapor pressure (temperature) scale between 1.1 and $4.4^{\circ} \mathrm{K}, \mathrm{J}$. Phys. Soc. Japan 21, 27 (Dec.).

Schwarzer, H., Electrical temperature measurement for low temperatures, Arch. Tech. Messen. No. 368,203 (Sept.).

Low temperature scale, Instr. Control Systems 39 , 94, (Jan.). 
Tables for high-temperature thermocouple, Glass Ind. 47, No. 5, 267, (May).

1967

Chandler, E. M., Thermocouple reference tables, Air Force Flight Dynamics Lab, Wright-Patterson AFB, Ohio, Summary report: Report No. AFFDL-TR66-178; Project No. AF-1368; Task: 136804; AD815097 (Mar.).

Cumo, M., and D. Pitimada, Determination of the Leidenfrost temperature, Translation by A. Crozy (Atomic Energy Research Establishment, Harwe11, England) from paper presented at 22nd National ATI (Air Technical Intelligence) Congress, Rome, Italy; CONF-670990-1; NSA-23:43457 (Sept.).

Hall, J. A., The early history of the international practical scale of temperature, Metrologia $\underline{3}$, No. 1,25 , (Jan.).

Ha11, J. A., and C. R. Barber, The evolution of the international practical temperature scale, Metrologia 3 , No. 3, 78 (July).

Orlova, M. P., et al, Broadening the international practical temperature scale in the zone below oxygen point, $\mathrm{Tr}$. Vses. Nauch.-Issled. Inst. Fiz. Tekh. Radio-tekh Izmer., No. 92, 40.

Suter, H., Applying melting-point determinations, Instr. Control Systems 40 , No. 8, 123, (Sept.).

Thomas, W., Realization of the thermodynamic temperature scale over the range $-183^{\circ} \mathrm{C}$ to $+1063^{\circ} \mathrm{C}$ by gas thermometer measurements, Get-Together on Thermometry, Nat. Phys. Lab., New Delhi, Pap. 1.2 (13-17, Feb.).

Van Tiggelen, P. J., and A. Duval, The concept of a mean temperature in the flame reaction zone, Acad. Roy. Belg. Bull. Classe Sci. 53, No. 4, 326, Grant No. AF EOAR 66-44.

\section{8}

Colarusso, V. G., and M. A. Seman, Measurement of calibration standards for therometry, Anal.

Chem. 40, 1521, (Aug.).

Culbert, H. V., and 2. Sungaila, Calibration of a resistance thermometer down to $0.4 \mathrm{~K}$ using a specimen known heat capacity, Cryogenics $\underline{8}$, No. 6,386 .

Fortunato, J., and W. Contreras, Temperature transducer calibration in the $4.2 \mathrm{~K}$ to $100 \mathrm{~K}$ range. Bioastronautics-environment, Grumman Aircraft Engineering Corp., Bethpage, N.Y., For copies: Army IDEP Office, Attn: ASMSI-RBP. Redstone Arsenal, Ala., AD-842315L.

Haywood, R. W., Rational treatment of temperature and temperature scales, Inst. Mech. Engrs. Proc. 182 , No. 21,501 .

Huntzicker, J. J., An absolute temperature scale for cerium magnesium nitrate below $0.002 \mathrm{deg} \mathrm{K}$, Ph. D D thesiş, Calif. Univ., Berkeley, N6923588;
Preston-Thomas, H., and C. G. M. Kirby. Gas thermometer determinations of the thermodynamic temperature scale in the range $-183^{\circ} \mathrm{C}$ to $100^{\circ} \mathrm{C}$, Metrologia 4 , No. 1, 30, (Jan.).

Preston-Thomas, H., and R. E. Bedford, Practical temperature scales between $11 \mathrm{~K}$ and $273 \mathrm{~K}$, Metrologia 4 , No. 1,14 , (Jan.).

Salomatov, V. V., The law governing temperatures within a body under conditions of non-linear thermal conductivity, Izv. Vysshikh Uchebn. Zavedenii. Fiz. (USSR), No. 9, 152.

Sandfort, R. M., and E. J. Charlson, Calibration curves for gold-nickel and silver-nickel thin film thermocouples, Solid-State Electronics 11, No. 6,635 , (June).

Snelleman, W., A flame as a primary standard of temperature, Metrologia 4, No. 3, 117, (July).

Snelleman, W., and J. A. Smit, A flame as a secondary standard of temperature, Metrologia 4 , No. 3,123 , (July).

Verosh, T., et al, Diagrams for high-temperature measurements, Zh. Prikl. Spektroskopii 8, No. 6, 920, (June).

1969

Astrov, D. N., M. P. Orlova, and G. A. Kytin, PRMI temperature scale in the range from $4.2 \mathrm{~K}$ to 20K, Metrologia 5, No. 4, 111, (Oct.).

Bedford, R. E., et al, Derivation of the CCT -68 reference function of the international practical temperature scale of 1968, Metrologia 5, No. 2, 45 (Apr.).

Bedford, R. E., et al, Relationships between the international practical temperature scale of 1968 and the NBS-55, NPL-61, PRMI-54, and PSU54 temperature scales in the range from 13.81 to 90.188K, Metrologia 5, No. 2, 47 (Apr.).

Belyanskii, L. B., et a1, Thermodynamic temperature scale in the $90-273.15^{\circ} \mathrm{K}$ range and its comparison with the international practical temperature scale, Izmeritel Tekhn. (USSR) $1,35$.

Belyanskii, L. B., et al, Comparrison of the NPL, VNIIFTRI, and NRC temperature scales in the range $90-273.15^{\circ} \mathrm{K}$, Meas. Tech. (USSR) $\underline{3}, 352$, (Mar.).

Benedict, R. P., International practical temperature scale of 1968, Instr. Control Systems $\underline{42}$, No. 10,85 , (Oct.).

Bentley, R. E., The EMF criteria for international practical temperature scale thermocouples, Metro logia 5 , No. 1, 26, (Jan.).

Emery, A. F., and W. W. Carson, An evaluation of the use of the finite element method in the computation of temperature, Sandia Labs., Livermore, Calif.; Contract AT 29-1-789, (SCL-RR-6983); CFSTI, (Aug.). 
Finkel'shtein, V. E., Possibility of deriving a temperature scale by means of the absolute optical method, Meas. Tech. (USSR) 7 , 944, (July).

Formanek, J., Negative absolute temperatures in statistical physics; Kvantova Elektronika, edited by B. Kvasil, Prague; Academia, Nakladatelstvi Ceskoslovenske Akademie Ved, 1968, 39-44; A6935403 .

Hudson, R. P., Account of the controversy surrounding the temperature scale for CMN, Cryogenics 9 , 76, (Apr.).

Kandyba, V. V., Questions of the accuracy of construction and transmission of the international practical scale of temperature, Meas. Tech. (USSR) 9, 1211, (Sept.).

Konig, B., Contribution to the theory of thermoelectric phenomena in inhomogeneous semiconductors, Fyzikalny Casopis, 19, 3, 175; A69-40933.

Kunz, H., Representation of the temperature scale above $1337.58 \mathrm{~K}$ with photoelectric direct current pyrometers, Metrologia 5 , No. 3, 88 (July).

Miyazato, M., T. Koseki, and K. Amano, Photoelectric pyrometer as a working standard of calibration, Nat. Res. Inst. Meas., Tokyo, Japan, Keiryo Kenkyusho Hokoku 18, No. 1,1 .

Muijlwijk, R., M. Durieux, and H. Van Dijk, On the definition of an international practical temperature scale. The interpolation of differences in the resistance ratios of platinum thermometers between $91 \mathrm{~K}$ and 14K., Physica 43, No. 4, 615 .

Orlova, M. P., New international practical temperature scale, IPTS-68, Meas. Tech. (USSR) 8,1087 , (Aug.).

Rosenbaum, R. L., Some low temperature thermometry observations, Dept. Physics Materials Research Lab., Univ. Illinois, Urbana, Rev. Sci. Instr. 40, No. 4, 577 (Apri1).

Van Dijk, H., Concepts of temperature used in the international practical temperature scales, Physica 43, No. 4, 596 (Sept.).

Wintle, H. J., Experimental thermodynamics with a stretched wire, Queen's Univ. Kingston, Ontario, Canada, Am. J. Phys. 37, No. 4, 406 (Apri1).

The international practical temperature scale of 1968 (Adopted by the Comit International des Poids it Mesures) Metrologia 5 , No. 2, 35 (April) 


\section{Thermoelectric Devices}

1964

Chandon, H. C., Development of NERVA copperconstantan immersion thermocouples, Aerojet General Corp., Azusa, Calif., Contract SNP-1; NASA-CR-91271; RN-DR-0044; TID-23653; N68-17313 (Dec.).

Collier, G., Thermocouple program to investigate relative error, Westinghouse Electric Corp., Astronuclear Lab., Pittsburg, Pa., WANL-TME-948; NSA 20-29488 (Sept. 15).

Davisson, E. G., and R. K. Adams, Smoothed thermocouple tables, Proc. Instr. Soc. Am. Ann. Conf. 19, Part III, Paper No. 11,1-3-64.

Donne, M. D., Tests and data concerning Platinel - A new high temperature thermocouple, Engelhard Ind. Tech. Bul1. 5, No. 1, 5 .

Farrow, R. L., and A. P. Levitt, Tungsten/tungstenrhenium thermocouples in a carbon atmosphere, Army Materials Research Agency, Watertown, Mass., Proj. 1A024401A11003; AD-606565 (Ju1y).

Fine, S., et a1, Use of thermocouples for temperature measurement during laser irradiation., Life Sci. 3, 1475 (Dec.).

Goldberg, J. L., and H. M. King, Automatic switching of sensitive thermocouples, Electron. Eng. 36, 591 (Sept.).

Marécha1, J. C., Measurement of surface temperatures by thermocouples, Bull. Rilem, No. 23, 83, (June).

Schlumbom, F., Procedure for the determination of the relative humidity and temperature in small cavities, Z. Instrumentenk. 72, No. 12, 355.

Schroder, R., Response time of miniature shielded thermocouples, Motortech. Z. 25, No. 7, 297 (July).

\section{5}

Andreev, N. V. et al, Uncooled thermocouple for prolonged testing of metal temperatures, Meas. Tech. (USSR) 10, 969 (Oct.).

Berman, R. J., C. F. Brock, and D. J. Hunt1ey, Dilute gold-iron thermoelemtns in low-temperature thermocouples, Advan. Cryog. Eng. $¥ 0$, No. A-4, 233, Plenum Press, New York.

B1iss, P., and S. Fanciullo, High Temperature thermometry and Pratt and Whitney Aircraft-Cane1, Pratt \& Whitney Aircraft, Middletown, Conn., Rept. No. PWAC-462; AEC Accession No. 46722; N66-20304 (Feb, 8).

Bostwick, W. E., Some experiences with noblemetal, metal sheathed thermocouples. Third and final report, Lawrence Radiation Lab., Univ. of California, Livermore, Calif., UCRL7361, Pt. 3; NSA 20-41461 (Sept. 15).
Bragin, B. K., and N. G. Pupysheva, Errors in individual calibrations of chrome1-copel thermocouples, Meas. Tech. (USSR) 9, 818 (Sept.).

Callcut, V. A., Aging of Chromel-Alumel thermocouples, U. K. At. Energy Authority, Reactor Group. TRG Rept. 1021 R-X; NSA 20-4398; N66-14688 (Aug. 31).

Calvet, P., The transmission of heat in conduction calorimeters, J. Phys. (Paris) Supp1. 26, No. 10, 207A.

Cotter, T. P., Hypersonic plasma thermocouple, U.S. Patent 3,206,624 (Sept. 14).

Dutta, A. K., and R. Bhattacharya, Copper-molybdenite thermocouple, Indian J. Phys. 39, No. 5, 251 (May).

E11iott, M. N., and J. R. Grover, Measurement and control of gas temperature in the Fingal process, Brit. Chem. Eng. 10, No. 12, 846.

Ergardt, N. N., Thermoelectric properties of platinum-rhodium alloys, Teplofiz, Vys. Temp., Akad. Nauk SSSR $\underline{3}$, No. 5, 691 .

Finaev, Yu. A., Temperature measurements in studies of the combustion of solid fuel particles, Vest \pm Akad Navuk Belarusk, SSR Ser. Fiz. Tekh. Navuk., No. 3, 55; NSA 2029495.

Forgacs, R. L., et a1, High voltage cathode temperature measurement, Rev. Sci. Instr. 36, No. 8,1198 .

Giedt, W. H., and J. T. Chambers, A dual-element transducer for measuring high gas-stream temperatures, Trans. Am. Soc. Mech. Eng. 87C, 397, (Aug.).

Gross, P. M., et al, An advanced high temperature thermocouple for use on aerospace vehicles. Final Rept. Feb. 1964 - Nov. 1965, Weston Instruments Inc., Newark, N. J., AFFDLTR-66-24; $\mathrm{AD}-487788$.

Ha11, B. F. Jr., and N. F. Spooner, Temperature measurement in a graphite environment from 1600 $2500^{\circ} \mathrm{C}$, ISA Trans. 4, No. 4, 355 (Oct.).

Hellman, S., The travelling thermocouple; valuable tool in operating a tunnel $\mathrm{kiln}, \mathrm{Brick} \mathrm{Clay}$ Record 147, No. 1, 48 .

Kuhlman, W. C., Tungsten-osmium thermocouple, U. S. Atomic Energy Commission, U. S. Patent 3,320,098, May 16, 1967. Appl. (Feb. 24).

Kutateladze, K. S., et al, Thermocouple tips for the measurement of liquid aluminum temperature, Tsvetn. Metal 38, No. $8,53$.

Lapp, G. B., and D. I . Popova, Thermoelectric stability of thermocouples made of high-melting metals or their alloys, Meas. Tech., (USSR) 9, 816, (Sept.). 
London, G. E., Problem of parameter selection for a temperature measuring system using a thermocouple with a compensating circuit, Leningradskii Universitet, Vestnik, Seriia Matematiki, Mekhaniki i Astronomii 20, No. 13, 107.

Martin, R., A note on the measurement of temperatures in the domes of hot-blast stoves, Ind. Ceram., No. 574, 357.

Onuma, Y., Thermocouple consisting of germanium thin film deposited in vacuum. Jap. J. App 1. Phys. 4, No. 10, 814.

Palmer, E. P., and G. H. Turner, Response of thermocouple junctions to. shock waves, Utah Research and Development Co., Salt Lake City, Final Rept. ATLTR-66-36; AD-484507 (Dec.).

Ricker, T., and R. Lueck, Changes in the thermoelectric power and electric resistivity in a transverse magnetic field in alloys of the palladium-silver system, $Z$. Metallk. 56, No. 11 , 799 .

Rosenbaum, R. L., R. R. Oder, and R. B. Goldner, Comments on low temperature thermoelectric power of gold-iron versus copper thermocouples, Cryongenics $\underline{5}$, No. 3,174 .

Sharfshtein, A. Kh., Use of thermocouples made of alloys of tungsten and rhenium for measuring flame temperatures up to $3000 \mathrm{~K}$, Tr. Ufim. Aviats. Inst., No. 6,33 .

Simonyan, S. G., Automatic recording of the temperature field in high-frequency drying of material, Ind. Lab. 31, No. 10, 1524 (Oct.).

Stishov, S. M. and H. A. Tikhomirova, The insta1lation of thermocouples in high pressure chambers, Instr. Exp. Tech., No. 5, 1290 (Sept. - Oct.).

Trauger, D. B., Experience with stainless steel sheathed Chromel-Alumel thermocouples in irradiated experiments, Oak Ridge Nat'I Lab., Tenn., ORNL-TM-1320; NSA 20-4263 (Nov. 12).

Polyimide thermocouple plugs, Plastics World 23 , 94 (Oct.).

\section{6}

Alexander, W. E. Standardizing surface-temperature measurement, Instr. Soc. Am., Nat. Aerospace Instr. Symp., 12th, Philadelphia, Pa., May 2-4, 1966, Proc., A67-11134

Alvermann, W., Determination of temperature profiles with thermocouples, Z. Flugwissenschaften 14, 179, German (Apr.).

Andreev, N. V., et al, Uncooled thermocouple for prolonged testing of metal temperatures, Meas. Tech., (USSR) 10, 969 (Apr.).
Barber, J. A., Measurements of high temperatures, High temperature thermometry; paper No.23 presented at a seminar at AEC Headquarters, Washington, D. C. on February 24-26, 1965 (WASH1067; TID-4500) Washington, Division of Reactor Development and Technology, U. S. Atomic Energy Commission; 1966; N67-19635 (Mar.).

Bascombe, K. N., Thermal equilibrium of wires in hot gas streams, Explosives Research and Deve1ment Establishment, Waltham Abbey, Essex, (England) AD-804163 (Aug.16).

Bennett, R. L, et al, Thermal emf drift of refractory metal thermocouples in pure and slightly contaminated helium atmoshperes, High temperature thermometry; paper presented at a seminar at AEC Headquarters, Washington, D. C. on February 24-26, 1965 (WASH -1067; TID-4500) Washington, Division of Reactor Development and Technology, U. S. Atomic Energy Commission, 1966; N67-19627 (Mar.).

Bliss, P. and S. Fanciullo, High temperature thermometry at Canal, Pratt \& Whitney, IEEE Trans. on Nuclear Science NS-13, 643; N67-19641 (Feb.).

Bobkov, V. P. et al, Study of the response of microthermocouples use in measuring non-steady temperatures, Teploenerg., N008 57. (Aug.).

Bragin, B. K., K. Z. Gomel'skii, and G. B. Lapp, Nature of changes in the thermoelectric force of Chromel-Alumel thermocouples during operation, Tr. Gos. Nauchn-Issled i Proektn. Inst. Splavov i Obrabotki Tsvetn. Metal., No. 25, 94 ( Publ. 1967).

Briggs, N. H., and W. W. Johnston, Jr., Therma 1 emf drift of high-temperature thermocouples in helium and argon, High temperature thermometry; paper presented at a seminar at AEC Headquarters, Washington, D. C., on February 24-26, 1965 (WASH-1067; TID-4500) Washington: Division of Reactor Development and Technology, U. S. Atomic Energy Commission, 1966; N67-19626 (Mar.).

Brodier, M. J., Practical aspects of temperature control during heat treatment. Part 4, Trattamenti Dei Metalli 9, 24, (Dec.).

Brooks, W. B., Hollow bar thermowell extends thermocouple life, Hydrocarbon Process, 45, 182 (Aug.).

von Burger-Scheidlin, F., and P. Stottmann, A dynamic method for temperature measurement with thermocouples, Z. Flugwissenschaften 14, No. 4, 184, (Apr).

Burns, G. W., and J. S. Gallagher, Reference tables for the Pt -30 percent $R h$ versus Pt -6 percent Rh thermocouple, J. Res. Nat. Bur. Stand. 70C, 89 (Apr. - June).

Bzhozovski, V., et al, A dynamic thermocouple for measurement of plasma temperature to $4000^{\circ} \mathrm{C}$, Foreign Tech. Div., Wright-Patterson AFB, Ohio, Rept. No. FTD-MT-65-528; AD-643375 (Apr. 20). 
Cerny, F., K. Kopriva, and I. Svoboda, New shortresponse time thermometer, Strojirenstvi 16, No. 7,661 .

Danishevskii, S. K., et al, Molybdenum-rhenium alloy thermocouples, Meas. Tech. (USSR) 4, 508 (April).

Davydov, A. M., et al, Temperature measurement in a massive copper calorimeter by nichrome-Constantan thermocouples, Zh. Fiz. Khim. 40, No. 7, 1668.

Dittbenner, G. R., Intrinsic thermocouple for fast response, Instr. Control Systems 39, No. 12, 85 (Dec.).

Dunthorne, E. H., Measurement and control of furnace temperatures, Wire and Wire Prod. 41, No. 4, 555 (April).

East, R. A., and J. H. Perry, A short time response stagnation temperature probe, Southampton Univ. (England) Dept. of Aeronautics and Astronautics, AASU-264; N66-30498 (Mar.).

Emmenthal, K. D., Water-cooled thermo-sensitive probes for hot gas temperature measurements, Deut. Luft-Raumfahrt, Forschungsber., 66 (Oct.).

Fintinaru, N., Examination and removal of errors caused by changes in the external resistance during temperature measurements with thermocouples and millivoltmeters, Feingeraetetechnik 15, No. 7, 309 .

Funston, E. S., and W. C. Kuhlman, High temperature thermocouple and electrical materials research, General Electric Co., Cincinnati, Ohio, Nuclear Technology Dept., High Temperature Materials Program, 129; N67-26992 (Dec. 30).

Gerashchenko, O. A., and N. N. Ionova, Thermal emf of plated thermocouples, Meas. Tech. (USSR) 1, 93 (Sept.).

Gitter, V. M., et al, Device for measuring the temperature of liquid steel, Meas. Tech. (USSR) 12, 1546 (Dec.).

Glazov, B. M., Apparatus for the investigation of the thermo-emf of metals at high temperatures, Ind. Lab. (USSR) 32, No. 1, 128 (Jan.).

Gross, P. M., et al, An advanced high temperature thermocouple for use on aerospace vehicles, Weston Instruments Inc., Newark, N. J., Final report; AD-487788.

Haggin, J. H. S., Thermocouples for measuring temperature, Chemistry 39, No. 12, 34.

Hanneman, R. E., and H. M. Strong, Pressure dependence of the emf of thermocouples, J. Appl. Phys. 37, No. 12, 612 (Feb.).

Hendricks, J. W., and D. L. McElroy, Hightemperature high-vacuum thermocouple drift tests, High temperature thermometry; papers presented at a seminar at AEC Headquarters, Washington, D. C., on February 24 - 26, 1965 (WASH-1067; TID-4500)
Washington: Division of Reactor Development and Technology, U. S. Atomic Energy Commission, 1966; N67-19629 (Mar.).

Howells, G., Compensation in series thermocouple measurement, Instrum. Rev. 13, 419 (Oct.).

Hydick, S. E., Thermocouple errors in ablation materials, Instr. Soc. Am. Ann. Conf. and Exhibit, 21st, New York, N. Y., Oct. 24-27; A67-11104.

Ivanov, S., and L. Vatskichev, Thermocouple with increased sensitivity at $300-450^{\circ} \mathrm{K}$, Physics Department of Sofia University, Bulgaria, Pribory i Tekhn. Eksperime., No. 1, 205, Original article submitted (Feb, 20).

Johnson, J. R., Design and development testing of transducer temperature thermocouples, North American Aviation Inc., Space and Information Systems Div., Downey, Calif.; AD-805958L (Apr.).

Johnson, W. P., Ultra-high temperature thermocouple for aerospace application, Proc. 12th National Soc. Am. Aerospace Instr. Symp. 275.

Jones, T. P., Stabilizing type $K$ thermocouples, ISA J. 13 , No. 10,73 (Oct.).

Klein, C. A., M. P. Lepie, and R. N. Donadio, Analysis and experimental evaluation of an ultra-high temperature prolytic graphite thermocouple, Ratheon Co. Research Div., Waltham, Mass., Contract: AF-33(615)-2650; Proj: AF1469; Task: 146-907; AD-802214 (June).

Kocherzhinskii, Y. A., et al, Calibration of the VR-5/20 thermocouple to critical points up to $3000 \mathrm{C}$. Determination of the melting points of vanadium and niobium of high purity, Foreign Technology Div., Wright-Patterson AFB, Ohio, Report No. FTD-TT-65-1888; N66-27890; AD630971 (Mar.).

Laboda, S., Use of noble metals and nobel metal alloys for temperature measurement, Meres. Autom 14 , No. 3,85 . :

Leonard, J. H., and J. S. Crutchfield, Transient radiation effects on thermocouples, Trans. Am. Nucl. Soc. 9, 570, (Oct. - Nov.).

Lifshits, A. G., et al, Use of the VR-5/20 thermocouple for measuring the temperature of metal in stee1-making, Ind. Lab. (USSR) 32, No. 11, 1745 (Nov.).

Makarov, B. I., Errors in the measurement of temperatures at the surface of a solid by means of a thermocouple in the case of heating and cooling in accordance with an arbitrary law. J. Eng. Phys., 16; N66-23988 (Jan. 3).

McCoy, H. E. Jr., Influence of $\mathrm{CO}_{-} \mathrm{CO}_{2}$ environments on the calibration of Chromel-P Alumel thermocou ples, Oak Ridge National Lab., Tenn., ORNL-1070; N66-18908. 
Moore, J. P., and D. L. McE1roy, Contamination of platinum-rhodium transducers, High temperature thermometry; paper presented at a seminar at AEC Headquarters, Washington, D. C., on February 24-26, 1965 (WASH-1067; TID-4500) Washington: Division of Reactor Development and Technology, U. S. Atomic Energy Commission, 1966, N67-19631 $(\operatorname{Mar}$.$) .$

Nanigian, J., Ribbon thermocouples in the $3000^{\circ}$ to $5000^{\circ} \mathrm{F}$ range, Instr. Control Systems 39, 93, (May).

Neugebauer, J., and L. Kortvelyessy, Tungsten-rhenium thermocouple usuable up to $2600^{\circ}$, Meres. Autom. 14, No. 12, 365 (Dec.).

Novikov,, L. V., Thermoelement which operates as a temperature transducer, Meas. Tech. (USSR) 7 , 978, (July).

Peters, E. T., and J. J. Ryan, Comment on the pressure dependence of the emf of thermocouples, $J$. App1. Phys. 37, 933, (Feb.).

Pletenetskii G. E., Thermocouples for measuring high temperatures in a vacuum, Pribory i Tekhn. Eksperim. No. 1, 203, (Jan. - Feb.).

Purslow, D., Transient response of a commercial stick-on thermocouple, Royal Aircraft Establishment, Farnsborough, Eng., Report No. RAE-TR-66 313; AD-814 539 (Oct.).

Ridenour, C. J., Thermocouple maintenance and installation considerations, Minerals Process $\underline{7}$, No. 9,11 .

Salzano, F. J., Stability of a rhenium-graphite thermocouple, High temperature thermometry; paper presented at a seminar at AEC Headquarters, Washington, D. C., on February 24-26, 1965 (WASH-1067; TID-4500) Washington: Division of Reactor Development and Technology, U. S. Atomic Energy Commission, 1966; N67-19646.

Scheppner, E. E., Instrumentation equipment specification thermocouple, fixed-immersion, enclosed-junction, iron-constantan, Rocketdyne, Canoga Park, Calif.; Report No. IES-6-004; AD-806 714L (Jan.).

Scheppner, E. E., Instrumentation engineering specification thermocouple, variable immersion, Rocketdyne, Canoga Park, Calif; Final specification; Report No. IES-6-006; AD-806-716L (Jan.).

Scheppner, E. E., Instrumentation equipment specification thermocouple, fixed-immersion, enclosed-junction, iron-constantan, Rocketdyne, Canoga Park, Calif.; Final spec. Report No. SPEC-IES-6-004; AD-831 002L (Aug.).

Schriempf, J. T., and A. I. Schindler, Low temperature thermoelectric power of gold-iron vs silver normal thermocouples, Cryogenics 6 , No. 5,301 (Oct.).

Schweyher, K., Measuring errors of insulated thermocouples of nonprecious metals in oxidiz- ing and reducing atmospheres, Stah1 Eisen 86 , No, 5 262 .

Sherwood, A. E., A sealed glass thermocouple and adjustable thermostat assembly, Lab. Pract. 15, No. 6, 669 (June).

Shimanskii, Yu. N., et a1, Measurements of temperature in a high-frequency magnetic field, Meas. Tech. (USSR) 10, 971 (Apr.).

Snyder, E. F., and M. C. Ziemke, Therma1 radiation shields, Instr. Control Systems 39, 101, (May).

Sorokin, Yu. V., and K. P. Zakharova, Temperature measuring during pyrochemical reactions, Zavodsk. Lab. 32 , No. 9, 1104 .

Sparks, L. L., and R. L. Powe11, Thermometry Project; Rept. No. NASA-CR-80343; N67-12965.

Stadnyk, B.'T., et al, High temperature thermocouples for measuring temperatures of an oxidizing medium, Mekh. Avtomat. Upr. 2, 43.

Stevenson, J. A., Control of glass melting furnaces; temperature measurement with platinum thermocouples, Platinum Metals Rev, 10, 128 (Oct.).

Stromberg, H. D., and D. R. Stephens, Effect of pressure on the temperature calibration of $\mathrm{Mo} / \mathrm{Mo}-50 \% \mathrm{Re}$ thermocouples to $1000^{\circ} \mathrm{C}$ and 60 kilobars. Lawrence Radiation Lab., Univ. of Calif., Livermore; Report No. UCLR-14993; AEC accession No. 43636 (Ju1y 15).

Sturge, D. W., Thermocouples which can be directly contacted with carbon at high temperature, European Atomic Energy Community, Belg. 698,122, 16 Brit. App1. (May 18).

Thomas, M. W. and K. E. Meredith, The embrittlement of nickel base alloys containing aluminum and chromium as used for thermocouple materials, Brit. Corrosion J. 1, No. 5, 199 (Mar.).

Volynets, A. Z., A thermocouple for measuring temperature in a high-frequency electric field, Ind. Lab. (USSR) 32, No. 8, 1261, (Aug.) .

Walker, B. E. Jr., Instability of noble metal and refactory metal thermocouples from $1000^{\circ}$ to $1700^{\circ} \mathrm{C}$, High temperature thermometry paper presented at a seminar at AEC Headquarters, Washington, D. C., on February 24-26, 1965 (WASH-1067; TID-4500) Washington: Division of Reactor Development and Technology, U. S. Atomic Energy Commission, 1966.

Walker, B. E. Jr., C. T. Ewing, and R. R. Miller, Instability of refractory metal thermocouples, Naval Research Lab., Washington, D. C., NRL6231; AD-621484; N66-10829.

Weissenberger, E. G., How bare wire and sheathed thermocouples compare, Metal Progr. 89, 93 (Feb.).

Wolkoff, J., et al, Thermocouple for the measurement of the surface temperature of a liquid meta1, Chem. Eng. Sci. 21, No. 10, 895. 
Zysk, E. D., and D. A. Toenshoff, Calibration of refractory metal thermocouples, Annu. ISA (Instrum. Soc. Amer.) Conf. Proc. 21, 1, 12.11-466.

High-temperature thermocouples and electric materials research, General Electric Co., Cincinnati, Ohio, High Temperature Material Programs, Part A, N66-34097 (Feb. 28).

Coating for thermocouples withstands $4700^{\circ} \mathrm{F}$, Mach. Des. 38, No. 12, 26 (May).

Sprayed coating for thermocouple, 0il Gas J. 64, 223 (Oct. 10).

High temperature materials p̈rogram, Progress Report No. 55, Part A, General Electric Co., Cincinnati, Ohio, GEMP-55A; N66-26801.

\section{7}

Asamoto, R. R., and P. E. Novak, Tungsten-rhenium thermocolples for use at high temperatures, Rev. Sci. Instr. 38, No. 8, 1047 (Aug.).

Beduhn, M., and W. Heyne, A precision Pt/Rh-Pt thermocouple for research and industry, Feingeraetetechnik 16, No. $6,257$.

Block, D., and F. Chaisse, Effect of pressure on emf of thermocouples, J. Appl. Phys. 38, 409 (Jan.) .

Bratanov, V., Thermocouple for measuring temperature of molten slag, Rudodobiv. Met. (Sofia) 22, No. 2, 53 .

Brewer, W. D., Effect of thermocouple wire size and configuration on internal temperature measurements in a charring ablator, National Aeronautics and Space Administration, Langley Station, Va.; NASA-TN-D-3812; N67-18407 (Mar.).

Brzozowski, W., H. Jedrzejec, and S. Suckewer, Measurement of gas temperature exceeding the melting point of the thermocouple, Instytut Badan Jadrowych, Pol. 53,719, App1. 01 (Aug. 30).

Brzozowski, W., S. Suckewer, and H. Jedrzejec, Dynamic thermocouple for measuring plasma temperatures up to $4000^{\circ} \mathrm{C}$, In Low-Temperature Plasma; International Congress on Theoretical and Applied Chemistry, 20th International Symp. on Properties and Applications of Low-Temperature Plasma, USSR, July 15-17, 1965. Edited, A. E. Sheidlin; Moscow, Izdatel Stvo Mir 295.

Burley, N. A. and R. G. Ackland, The stability of the thermal electromotive force/temperature characteristics of nickel-base thermocouples, J. Australian Inst. Metals 12, No. 1, 23.

Cerney, F., Thermocouple well with a low temperature lag for measuring steam and gas temperatures, Teploenerg. 14, No. 2, 84 .

Coggliola, G., P. Marcarino, and S. Sartori, Reproducibility of thermocouple temperature characteristics after heating and cooling cycles be- tween 0 and $600^{\circ} \mathrm{C}$, Termotecnica (Milan) 21, No. 1,45 .

Creamer, E. L., et al, Sulfuric corrosion of Chromel-Alumel thermocouples, Corrosion 23, 297 (Oct.).

Crovini, L., and P. Marcarina, Calibration of standard thermometers of thermoelectric fixed points between $630.5^{\circ}$ and $1063^{\circ} \mathrm{C}$, Termotecnica (Milan) 21, No. 1, 34 .

Dittbenner, G. R., Development and application of the intrinsic thermocouple for fast response, California Univ., Livermore, Lawrence Radiation Lab. , UCRL-14593; N67-22327.

East, R. A., and J. H. Perry, A short time response stagnation temperature probe, Aeronautical Research Council, London, England, Current papers, Report No. ARC-CP-909; AD-809 895.

Evans, R. A., and J. Holt, Calibration drift effects in nickel-alloy thermocouples, U.K. At. Energy Authority Reactor Group, TRG Report No. 151 (R).

Fenton, A. W., Metal-sheathed mineral-insulated base-metal thermocouples, United Kingdom Atomic Energy Authority, Risley (England) Reactor InPile Irradiation Equipment and Tech., 43; N6736546 (Oct. 15).

Gil'dengarn, I. S., and I. L. Rogel'berg, Kinetics of high-temperature oxidation of industrial thermocouple alloys, Tr. Gas. Nauchn-Issled., Proekt, Inst. Splavov Obrab. Tsvetn. Metal 25, 167.

Gries, W. H., Thermocouples calibrated through simple set-up, Chem. En. 74, No. 26, 130.

Gruenendiek, W., and J. Volkery, Multiple differential thermcouple as a continuously operating instrument, Energie 19, No. 6, 205 (Jan.).

Hager, N. E. Jr, Making and applying a thinfoil heat flux sensor, Instrum. Technol. 14, 54, (Oct.).

Hal1, G. R., and J. A. Bogdanovic, Response of bare wire thermocouples to temperature variations in a jet engine intake, J. Aircraft $\underline{4}$, 394 (July).

Heim, D. C., Information equipment specification, ignition detection thermocouple, Rocketdyne, Canoga Park, Calif., Final Spec. Report No. SPEC-IES-7-004A; AD-839 985L (June).

Hendricks, J.W., and D. L. McElroy, High temperature-high vacuum thermocouple drift tests, Environ. Quart. 13, 34 (Mar.).

Henning, C. D., and R. Parker, Transient response of an intrinsic thermocouple, J. Heat Transfer 89, No. 2, 146, UCRL-14862 (May).

Holland, J. T., Describing temperature-emf relationship for thermocouples, Instr. Control Systems 40 , No. 12, 97 (Dec.). 
Ivanov, S., and L. Vatskichev, Thermocouple with increased sensitivity at $300-450^{\circ} \mathrm{K}$, Prib. Tekh. Eks. (USSR) No. 1, 205 (Jan.).

Jones, E. W., Facile thermocouple calibrations, Instr. Control Systems 40, No. 5, 135 (May).

Koeppe, W., Low temperature thermocouple, goldcobalt (2.1 per cent AT.) versus Chromel, Cryogenics 2 , No. 3, 172 (June).

Lagutin, V. I., Automatic application of corrections for the temperature of the free ends of thermocouples, I zmeritel. Tekn. (USSR) $\underline{7}, 91$ (July).

Larson, M. B., Time-temperature characteristics of thin-skinned models as affected by thermocouple variables, Semiannual Report, North Dakota Univ., Grand Forks, NASA-CR-84500; SAR-4 N67-27667.

Loiseleur, B., P. Clechet, and J. Merlin, Standardization of thermocouples by a dynamic comparative method: application to copper-Constantan and Chromel-Constantan (BTE-CTE) thermocouples, Bull. Soc. Chim. France 2, 677.

McElroy, D. L., Thermocouple drift tests to $800^{\circ} \mathrm{C}$ at $10^{-7}$ Torr on Chromel-P vs Constantan, Temperature Measurements Society, Conference and Exhibit, 5th, Hawthorne Calif., Proc.; A67-34501 (March 14 - 15).

Newhouse, K. N., Thermocouple conduction errors in a vacuum cold wall environment, ASME \& AICHE American Society of Mechanical Engineers and American Institute of Chemicals Engineers, Heat Transfer Conference and Exhibit, Seattle, Wash., ASME Paper 67-HT-57 (Aug. 6 - 9).

Odgen, J., Thermocouple life in kiln, Instr. Control Systems 40 , No. $1,123$.

Peshekhonov, N. F., Device for measuring the temperature of a gas flow, NASA-TT-F-11023; CFSTI; N67-29012 (June).

Pikashov, V. S., et al, On the problem of measuring flame temperature by the method of zero diameter extrapolation, Akad, Nauk (USSSR) Kiev; In it's Processes of Combustion and Heat Treatment of Materials, 69; N70-10886.

Pirro, P., The use of thermocoax Chromel-Alumel thermocouples for the measurement of small temperature differences, J. Sci. Instr. 44, No. 12, 1055 (Dec.).

Pletenetskii, G. E., Thermocouples for measuring high temperatures in a vacuum, Prib. Tech. Eks. 1, 203 (Jan. - Feb.).

Robba, W. A., Investigation of a very high temperature pyrolytic graphite thermocouple, Space Age Materials Corp., Woodside, New Jersey, Contract: AF 04 (611)-9949; AD-815 021 (Feb.).
Rinesch, R. F., Continuous thermocouple monitoring of LD furnace bath temperature, J. Metals 19, 26 (Feb.).

Rodchenkov, M. I., et al, Protective tip of silicized graphite for an immersion thermocouple, Izobret., Prom. Obraztsy, Tovarnye Znaki, 44, No. 24,122 .

Rogel'berg I. L., et al, Change in thermoelectromotive force of nickel wire during annealing and exploitation of it as a thermoelectrode for a thermocouple, Tr. Gos. Nauchn.-Issled. Proektn. Inst. Splavov Ohrab. Tsvet. 25, 113.

Rogel'berg, I. L., et al, Stability of thermoelectric force of Chrome1-Copel thermocouples during heating in air to $800^{\circ}, \mathrm{Tr}$., Gos. NauchnIssled. Proekt. Inst. Splavov Obrab. Tvset. Metal. No. 25, 66 .

Rolin, M., and G. Poupa, Contract pyrometry at temperatures above $1500^{\circ} \mathrm{C}$, Institut National des Sciences Appliquees, Lyons, France, Proceedings of $77 \mathrm{th}$ International Conference on Combustion and Energy; Paris, France on April 4 - 8; A68-38746.

Rom, J., and Y. Kronzon, Small shielded thermocouple total temperature probes, Technian Israel Inst. of Tech., Hafia Dept. of Aeronautical Engineering, Report No. SCIENTIFIC-6, TAE-79; Contract: F61052-67-C-0033; Project: AF-7063; N68-26060 (Dec.).

Randier, R., and R. Deniaux, Accurate measurement of the surface temperatures in a heat exchanger, Mes. Regul. Automat. 32, No. 10, 75 (Oct.).

Sannes, T, and N. V. Philips, Small-size thermocouples, Advance in design extends applications, Instrum. Technol. 14, No. 3,35 .

Sannes, T., Thermocoax thermocouples, Techniek en Taepassing, $26,23$.

Sannes, T, Thy thermocouples, Instrum, Technol. 14, No. 3,35 (March).

Scheppner, E. E., and D. C. Heim, Instrument ation equipment specification thermocouple, fixedimmersion enclosed-junction, Chromel-Alume1, Rocketdyne, Canoga Park, Calif., Final Spec. Report No. SPEC-IES-6-003; AD-831 088L (Jan.).

Scheppper, E, E., Instrumentation equipment specification: thermocouple, variableimmersion, Rocketdyne, Canoga Park, Calif., Final Spec. Report No. SPEC-IES-6-006; AD$831001 \mathrm{~L}$ (Jan.).

Schiefer, P., and M. Bretz, Digital temperature measurement by immersion thermocouples, Stahl Eisen 87, No. 7, 383 (Apr.).

Tichy, 0., Effect of reducing atmospheres on thermocouples based on platinum unprotected thermocouples, Sk lar Keram. 17, No. 6, 164. 
Villamayor, M., Study of thermocouples for control of high temperatures, Ph.D. Thesis; Lyon Univ.; N68-12648

Wasan, V. P., and C. L. Gupta, Thermocouples for high-temperature measurement, Engelhard Ind., Tech. Bu11. 8, No. 3, 77 .

Zysk, E. D., and D. A. Toenshoff, Calibration of refractory metal thermocouples, Englehard Ind. Inc. Tech. Bu11. 7,4 (Mar.)

Zysk, E. D., and D. A. Toenshoff, Thermocouple calibration methods above $1,500 \mathrm{deg}$. C, Instrum. Technol. 14, No. 1, 49 (Jan.).

Evaluation of thermometer, self indicating, bimetalic, Sperry Utah Co., Salt Lake City, Utah, Fina1 Report No. EJ-330-0949; Contract: DAAHO167-C-2136; AD-833 199L (Nov.).

\section{8}

Balko, B., and R. L. Berger, Measurement and computation of thermo-junction response times in the submillisecond range, Lab. of Tech. Deve1opement, Nat1. Heart Inst., Bethesda, Md., Rev. Sci. Instr. 39, No. 4, 498 (Apr.).

Bates, H. E., and M. Weinstein, On the efficiency of segmented Si-Ge-PbTe thermocouples, IEEE Pub1 ication 68C21-Energy; Contract No. NAS-9149; A68-42531.

Be11, P. M., J. L. Eng 1 and, and F. R. Boyd, Pressure effect on the platinum vs platinum $-10 \%$ rhodium thermocouple, Carnegie Inst. Wash., Yr. Book 66, 545.

Bouissou, H., The effects of radiation and method of attachment on the accuracy of thermocouples used for surface temperature measurement, Royal Air Estab; Farnborough, England, RAELIB-TRANS-1326; AD 846 229; N69-19745 (Oct.).

Bradley, D., and K. J. Matthews, Measurement of high gas temperatures with fine wire therocouples, J. Mech. Eng. Sci. 10, No. 4, 299 (Oct.).

Bragin, B. K., Thermoelectrical hetrogeneity of wires of alloys of platinum with $6-30 \%$ rhodium, Izmeritel Tekhn. No. 4, 22.

Burley, N. A., Thermoelectric instability in nickel-base thermocouple alloys, Defence Standards Labs, , Maribyrnong, Australia, Report No. DSL-317; AD-841 419 (June).

Carden, P. 0, et a1, A stationary contacting thermocouple device for measuring the temperature of rapidly moving surfaces, J. Sci. Instr. 1, No. 7, 757 (July).

Chopra, K. L., S. K. Bahl, and M. R. Randlett, Thermopower in thin-film copper-constantan couples, J. App1. Phys. 39, No. 3, 1525.

Conrad, G., Linearization of thermocouple voltages, Rev. Sci. Instr. 39, No. 11, 1682 (Nov.).
Daniels, G. E., Measurement of gas temperature and the radiation compensating thermocouples, J. App1. Meteoro1. 7, 1026 (Dec.).

Danisevskii, S. K., et a1, Calibration characteristic of type-VR $5 / 20$ tungsten-rhenium thermocouples, Izmerit. Tekhn. (USSR) No. 7, 20 (July

Dukarskii, S. M., M. I. Rodchenkov, and A. S. Tarabanov, Siliconized graphite as a material for the protective armature of an immersion thermocouple, High Temp. 6, No. 1, 156 (Jan. Feb.).

Efankin, G. A., E. A. Medvedev, and A. N. Vereshchaka, Quick-response method for measuring the temperatures in a methanol synthesis reactor, Kontr. Izmer. Tekh. Mezhvedom. Respub. Nauch.Tekh. Sb. No. 4, 144.

Ergardt, N. N., Temperature measurement with tungsten-rhenium and tungsten-molybdenum thermocouples and methods for their calibration, Izmerite1 Tekhn. 10, 24.

Feigenbutz, L. V., Thermoelectric potentials for a tungsten-tantalum thermocouple from 0 to $420^{\circ} \mathrm{C}, \mathrm{J}$. Sci. Instr. (G. B.) Series 2, 1, 489 (Apr.).

Fischer, S., Measurements of high temperatures in gas streams by thermocouples, Technik (Berlin) 23 , No. 1,29 .

Glawe, G. E., L. N. Krause, and T, J. Dudzinski, A small combination sensing probe for measurement of temperature, pressure, and flow direction, NASA TN D-4816, (Oct.).

Hagquist, C. H., How to increase thermocouple life in rotating equipment, Chem. En. 75, 126 (Dec. 16).

Howard, F. G., Single-thermocouple method for determining heat flux to a thermally thick wall, National Aeronautics and Space Administration, Langley Research Center, Langley Station, Va., NASA-TN-D-4737; CFSTI; N68-33208 (Sept.).

Hyncica, V., Measuring the surface temperature of metallic bodies on cooling in a fluid bath, Strojnicky Casopis 19, No. 4, 497.

Jones, T. P., The accuracies of calibration and use of I. P. T. S. thermocouples, Metrologia 4, No. 2, 80 (Apr.).

Kharchenko, M. G., Technique of obtaining by means of thermocouples, a signal proportional to the absolute temperature, Meas. Tech. (USSR) No. 10, 1339, (nct.).

King, W. H. Jr., C. T. Camilli, and A. F. Findeis Thin film thermocouples for differential therma1 analysis, Ana1. Chem. 40, No. 8, 1330.

Koenen, H., Thermocouples for temperature contro Instr. Contro1 Systems 41, No. 9, 115. 
Koshkin, 1. A., V. A. Krat, and V. I. Ostroverkhov, Production of zirconium diboride-based sheaths for thermocouples, Ogneupory 33, No. 1, 12.

Kosowski, A., and W. Zdzislaw, Change of characteristics of tungsten-molybdenum thermocouples depending on the type of junction and frequency of measurements, Pomiary, Automat. Kont. 14, No. 2,723 .

Kutzner, K., Gold-iron thermocouples, Cryogenics 8, 325 (Oct.).

Larrain, J., and C. F. Bonilla, Cross-conduction errors in thermocouples. Correction of long swaged thermocouples at high temperatures, Columbia Univ., N. Y. Nucl. Eng. Design ㅌ, 251.

Lidorenko, N. S., et a 1, Thermocouple, (USSR) Izobret. Prom. Obraztsy, Tovarnye Znaki 45, No. 34 , 177 (Sept.).

Moffat, R. J., Gas temperature measurement: direct design of radiation shielding, Stanford Univ., Stanford, Calif., Paper No. 68-517 (Oct. 28 31).

Moffat, R. J., Understanding thermocouple behavior: the key to precision, Stanford Univ., Stanford, Calif., Paper No. 68-628 (Oct. 28 - 31).

Moller, C. E., M. Noland, and B. L. Rhodes, NASA contributions to developement of specialpurpose thermocouples - a survey, NASA-SP-5050; U. S. Government Printing Office; Washington, D. C. 20402; N68-35620.

Morozov, S. 1., and E. D. Naumov, Determination of heat inertia of thermocouples in an axisymmetric air jet, Inzh. Fiz. Zh. (USSR) 15, No. 6, 1100 (Dec.).

Northover, E. W., and J. A. Hitchcock, The effect of heating on the local thermoelectric power characteristics of commercial thermocouple wires, Instr. Pract. 22, No. 7, 606 (July).

Olson, N. J., A recording thermobalance for materials research, Part 1.Constant heating rate thermogravimetry to $1400^{\circ} \mathrm{C}$, Dayton Univ., Ohio; Research Institute; Technical Report TR 68-184-Pt-1; Contract AF 33 (615)-3961; Proj. AF-7340; Task 743001; AD-675151; N6912305.

Otter, A. J., Thermocouples and surface temperature measurement, Atomic Energy of Canada, Ltd., Chalk River (Ontario) AECL-3062; N68-24123.

Parker, R., Response of thermocouples to a rapid temperature rise, Lawrence Radiation Lab., University of California, Livermore, Calif., Paper No. 68-512 (Oct. 28 - 31).

Pelepeichenko, I. P., et a1, Selection of the length of a thermocouple for measuring instantaneous temperature in nonstationary gas flows, Air Force Systems Command, Wright-Patterson AFB, Ohio, Foreign Technology Div., FTD-HT-23157-69; AD-694853; N70-14109.
Rein, C. R., A method for measuring the temperature distribution in stabilized flames, Tulane Univ., New Orleans, La., Ph.D Thesis; N69-27037.

Rogel'berg, I. L., T. F. Tarasousa, and I. S. Gil' dengarn, Negative thermoelectrodes of a thermocouple, Izobret. Prom. Obraztsy. Tokarnye Znaki, 45 , No. 11,100 .

Rosenbaum, R. L., Some properties of gold-iron thermocouple wire, Rev. Sci. Instr. 39, No. 6, 890 (June).

Sandfort, R. M, and E, J. Charlson, Calibration curves for gold-nickel and silver-nickel thin film thermocouples, Solid-State Electronics 11 , 635 (June).

Shmelev, G. I., and I. M. Krasheninnikova, Material for joining thermocouples (USSR) $\mathrm{C} 1 . \mathrm{H}$. $01 \mathrm{~m} 17$ (May), Translated from 1zobret., Prom. Obraztsy, Tovarnye Znaki 45, No. 22, 191.

Sibley, F. S., N. F. Spooner, and B. F. Hall Jr., Aging in type $\mathrm{K}$ couples, Instrum. Technol. 15, No. 7,53 (July).

Sibley, F. S., Thermocouple with nickel containing elements, U. S. Patent No. 3,411,956 (Nov, 19).

Sparks, L. L., R. L. Powe11, and W. J. Ha11, Progress on cryogenic thermocouples, Inst. for Basic Stand., NBS, Boulder, Colo., Advan. Cryog. Eng. 14, 316 .

Stoch1, R. J., and R. L. DeWitt, Temperature and liquid-1evel sensor for liquid-hydrogen pressurization studies, NASA, Lewis Research Center, Langley Station, Va., NASA-TN-D-4339; N68-15893.

Stawe, B. W., Embedded thermocouple temperature measurements of cooled turbine buckets to high heat flux conditions, ISA J. (Advances in Test Measurement 5, 538) A69-31274.

Sturge, D. W., Improvements in or relating to thermoelectric devices, British Patent $1,131,145$ (Oct. 23).

Terebukh, L. S, et al, Tungsten-rhenium thermocouples for periodically checking the temperature in furnaces for the fire refining of copper, Teplofiz. Vyx. Temp. (USSR) 6, No. 6, 1092 (Nov.).

Thomas, H. B., Ultra-high temperature thermocouples, 1nstr. Control Systems 41, No. 5, 91 (May).

Thornburg, D. D., The thermoelectric power of $\mathrm{Au}-\mathrm{Ni}$ thin film thermocouples, Illinois Univ., Urbana, I11., COO-1198-619; NSA-23:22651 (Oct.).

Tichy, 0., Effect of carbon-containing atmos-. pheres on platinum alloy thermocouples 11 , Protection of thermocouples and other measuring methods, Teplotechna, Olomouc, Czech., Sklar Keram. 18, No. $12,303$. 
Tseng, V., A. Robertson, and D. Edward, Platinummolybdenum thermocouple, Engelhard Ind. Div., Engelhard Miner and Chem. Corp., Newark, New Jersey, Engelhard Ind. Tech. Bu11. 9, No. 3, 77.

Villamayor, M., Study of thermocouples for measurement of high temperatures, Ph. D. Thesis, Contract NASw-1695; NASA-TT-F-11623; N6822383 (Apri1).

White, R. M., The determination of the elevated temperature Seebeck coefficients of common thermocouple materials referenced to platinum, Sandia Corp., Albuquerque, New Mexico, CFSTI (Oct.).

Wilson, A. D., and H. B. U1sh, Theory of the parallel thermocouple, Rev. Sci. Instr. 39, No. 3, 346 (March) .

Zedginidze, E., et al, Thermocouple well for measuring the temperature of molten aluminum Tbilis. Gos. Nauch.-Issled. Inst. Stroit. Mater. Tbilisi (USSR) Ognenpory 33, No. 9, 7 .

Developements with mineral-insulated thermocouples, Engineering (London) 205, 331 (Mar. 1).

Thermocouple erodes as it measures, Iron Age 202, 28 (Nov. 21).

Device for continuously measuring the temperature of hot media, British Patent No. 1,137,432 (Dec. 18) .

\section{9}

Aleksakhin, I. A., A. F. Plakushchaya, and N. V. Viktorova, Iridium alloy thermocouple for measuring temperatures up to $2100^{\circ}$ in an oxidizing atmosphere, $\operatorname{Tr}$, Gos. Nauch.-Issled. Proekt. Inst. Splavov Obrab. Tsvet. Metal No. 29,128 .

Aleksakhin, I. A., and N. D. Dukhovlinova, Thermocouples for measuring low temperatures, Tr. Gos. Nauch.-Issled. Proekt. Inst. Splavov Obrab. Tsvet. Meta1. No. 29, 150.

Alexander, W. E., A cryogenic liquid level/ temperature transducer, Cryog. Techn. 5, 110, A69-33670 (May - June).

Bailey, S. B, et al, Evaporated silver-aluminum thermocouples for low-temperature measurement, Univ. of North Carolina, Charel Hill, N. C., Rev. Sci. Instr. 40, No. 9, 1237.

Bal'zovskii, V. B, and 0. B. Orzhevskii, Influence of the method of preparation of copperConstantan thermocouples or their calibration curves, Ind. Lab. (USSR) 35, No. 8, 1222 (Aug.).

Bienkowski, A., A transistorized vacuum gage with a thermocouple probe, Warsaw (Poland) Nukleonika 13, No. 8, 117; N70-22162.

Bjornson, G., High-temperature zirconia-coated thermocouple, Phillips Petroleum Co., C1. 136 (Aug. 19).
Bontrager, P. J., Developement of thermocoupletype total temperature probe in the hypersonic flow regime, Arnold Eng. Develp. Center, Arnold Air Force Station, Tenn., Report No. AEDC-TR69-25; AD-681489; N69-22315 (Jan.).

Campbe11, G. S., Measurement of air temperature fluctuations with thermocouples, Atmospheric Sciences Lab., White Sands Missile Range, New Mexico, Technical Report No. 5273; Proj. DA-1061102-B-53A; Task 1-T-061102-B-53-A-17; AD697107; N70-18316 (Oct.).

Danishevskiy, S. K., Rhenium-tungsten alloys as material for high temperature thermocouples, Air Force Systems Command, Wright-Patterson AFB, Ohio, Foreign Technology Div., FTD-MT24-11-69; AD-689308; N69-37201 (Mar. 6).

Fedorovskii, M. L., Measuring temperature of liquid steel with immersion thermocouples, Meas. Tech. (USSR) 5, 756 (May).

Fialkov, A. S, et al, Thermocouple for measuring high temperatures (USSR) 0tkrytiya, Izobret. Prom. Obraztsy, Tovarnye Znaki 46, No. 17, 78.

Fries, R. J, et al, Compatibility of some hightemperature thermocouple materials in a carbon. hydrogen environment, Los Alamos Sci. Lab., Los Alamos, New Mexico, J. Nucl. Mater. 32, No. 1,171 .

Goemans, T., Temperature measurement by thermocouples; experiment and signal recordings in the temperature region 0 to $2500^{\circ} \mathrm{C}$, Paper No. THD-KR-190; WTHD-13; N70-16803 (June) .

Herchakowski, A., Life and performance character istics of $\mathrm{Pb}$ - Te couples in hydrocarbon fired systems, Army Electronics Command, Fort Monmouth, New Jersey, Power Sources Div., Proj DA-1-T-662705-A-053; Task 1-T-662705-A-05304; AD-699312; N70-24198 (Dec.) .

Hofmann, D., Measurement dynamics of thermocouples, Natioflal Lending Library for Science and Technology, Boston Spa (England) NLL-CETRANS-4956-(9022.09); N70-11368 (July 18).

Hube, F. K., Thermocouple total-temperature, probe-radiation errors, AIAA J. 7, 587; A69-31903 (Apr.).

Huff, R, G., A thermocouple technique for measuring hot-gas-side wall temperatures in rocket engines, NASA Lewis Research Center, Cleveland, Ohio, NASA-TND-5291; N69-29553 (June) .

Huff, R. G., Apparatus for sensing temperatures; Patent application, NASA Lewis Research Center, Cleveland, Ohio, NASA-CASE-XLE -52301; U. S. Patent-App1. -SN-877717; N70-22135, Application filed (Nov, 18).

Ito, S., Thermocouples, Seiji Kotai Butsuri 4, No. 2,92 . 


\section{Thermoelectric Devices}

Kenyan, R. A., and J. D. Randal1, An extended figure of merit for the plasma thermocouple, Energy Conservation 9, 119; A69-40134 (Aug.).

Korenblit, L. L., and A. G. Samoilovich, Material for a thermocouple (LSSR) Otkrytiya, Izobret., Prom. Obraztsy, Tovarnye Znaki 46, No. 12, 39 .

Kortvelyessy, L.x-et al, Tungsten-rhenium thermocouple, Hungarian Patent No. 156,021 (May 27).

Larson, M. B., and E. Nelson, Variables affecting the dynamic response of thermocouples attached to thin-skinned models, J. Heat Transfer 91, 166; A69-27785 (Feb.).

Loiseau, H., and D. Chaumette, Remarks on the use of thermocouples subjected to a flow of radiated heat, Rech. Aerosp. 129, 57; A69-33596 (Mar. - Apr.).

Malim, T. H., Thermocouples tell it like it is, Iron Age 204, 67 (Aug. 28).

Malyshev, V. N., High temperature thermocouple based on graphite, Ind. Lab. (USSR) 35, No. 7, 1064 (July).

Meier, H. U., A combined temperature and pressure probe for compressible flow, AIAA J. 7, 529; A69-28226 (Mar.).

Meiser, J. H., An inexpensive, inert thermocouple probe, Univ, Dayton, Ohio, J. Chem. Educ. 45, No. 7, 476 (July).

Nacy, J., et al, Thermocouple for measuring the temperature of melts, Hungarian Patent No. 156, 022 (May 27).

Parker, R., Response of thermocouples to a rapid temperature rise, ISA Trans. 8, No. 2, 122.

Pelepeichenko, I. P., and 0. V. Diakovskii, Selection of structural dimensions for thermocouples in the measurement of unsteady temperatures in gases, Priborostroenie 12, No. 4, 116; A69-561 97.

Perry, J. H., and R. A. East, A miniature total temperature probe for boundary layer measurements in short running time hypersonic facilities, International Congress on Instrumentation in Aerospace Simulation Facilities, 3rd, Poly. Inst. of Brooklyn, Farmingdale, New York; A69-35751 (May 5-8).

Raag, V., Relationship of changes in the heat input to the power output of a thermoelectric device, Resalab. Scientific, Menlo Park, California, NASA-CR-109628; N70-25689 (July 30).

Ramert, B., A thermocouple, Foreign Technology Div., Wright-Patterson AFB, Ohio, Report No. FTD-HT-23-122-69; AD 861420 (May).

Richards, D. B., L. R. Edwards, and S. Legvold, Thermocouples in magnetic fields, J. Appl. Phys. 40, No. 9, 3836 (Aug.).
Rosenbaum, R. L., Some low temperature thermometry observations, Rev. Sci. Instr. 40, No. 41, 577 (Apri1).

Sibley, F. S, and N. F. Spooner, Nickel alloy thermocouple, Hoskins Manufg. Co., U. S. 3,457 122 (July 22).

Sparks, L. L,, and W. J. Ha11, Cryogenic thermocouple tables, Part 3: Miscellaneous and comparison material combinations, Nat. Bu. of Standards, Boulder, Colorado, Cryogenics Div., NASA-CR-1077 49; N70-16817 (Jan.).

Starner, K. E., and R. L. Varwig, Thick film thermocouple gauges for roughened model heat flux mea surements, Aerospace Corp., E1 Segundo, California, Lab., Operations, Report No. TR0066 (5240-10-1) SAMSO-TR-69-359; N70-20329 (Feb. - May).

Starr, C. D., and Teh Pu Wang, Thermocouples and extension wires, Instr. Control System 42, No. 10, 111 (Oct.).

Stowe, B. W., Embedded thermocouple temperature measurements of cooled turbine buckets subjected to high heat flux conditions, ISA Trans. 8, No. 2,126 .

Szaniszlo, A. J., Thermal electromotive force change for $87 \mathrm{PT}-13 \mathrm{Rh} / \mathrm{PT}$ thermocouples in $1530 \mathrm{~K}, 10$ to the minus 8 environment for 3700 hours, NASA-TN-D-5287; N69-29196 (June).

Tarasova, T. F., I. L. Rogel'berg, and I. S. Gil' dengorn, Thermocouples of palladium-containing alloys, Tr., Gos. Nauch.-Issled. Proekt. Inst. Splavov Obrab. Tsvet. Metal No. 29, 140.

Tyushev, V. S., and 0. V. Shelud 'ko, Germanium film thermocouple, Ind. Labs., (USSR) 35, No. 9, 1378 (Sept.).

Zysk, E. D., E. E. Osovitz, and R. W. Stephans, Noble metal thermocouple having base metal compensating leads, Engelhard Industries, Inc., U.S. 3,451,859 (June 24).

Concentric miniature thermocouples, Instrum. Technol 16, No. 3, 57 (March).

Tip for temperature measurement, Iron Age 204, 64 (July 24). 


\section{Resistance Devices}

1964

Fogel'son, I. B., Temperature measurement with germaniun triodes, Izmeritel. Tekhn. 12, 15.

Orlova, D. N., et al, Germanium resistance thermometers, Com. Consult. Thermom, , Com. Int. Poids Mes., Sess., 7th, (Paris) 114. (Publ. 1966).

\section{5}

Ambrok, G. S., Determination of the inertia of protective coatings on film resistance thermometers, High Temp. 3, No. 2, 263 (Mar.-Apr.).

Bazlova, I. V, et al, Method of measurement of small heat effects by thermistors, Tr. Mosk. Khim. Technol. Inst., No. 49, 32.

Benjaminson, A., The quartz thermometer - A temperature measuring system with direct digital readout, Proc. lst Internat. Conf. Thermal Analysis, Aberdeen (London) Macmillan, 32.

Brown, R. D., Qualification test of thermal semiconductor resistor, LMSC P/N 1616310-17, Final Rept. No. LMSC-A-621044; AD-484846L (Apr.)

Campbe11, D. S., and B. Hendry, The effect of composition on the temperature coefficient of resistance of $\mathrm{Ni} \mathrm{Cr}$ films, Brit. J. Appl. Phys. 16 , No. 11,1719 (Nov.).

Chandon, H. C., D. E. Hopping, and S. Takeda, Standardized temperature-measurement system with constant-current excitation and platinum element transducers, Proc. Instr. Soc. Am. Ann. Conf. 20, No. 3 .

Cooper, M. G., and A. J. P. Lloyd, Miniature thin film thermometers with rapid response, J. Sci. Instr. 42, 791 (Nov.).

Corruccini, R. J., Sondheimer-Wilson-Kohler formula in platinum resistance thermometry, $\mathrm{J}$. Res. Nat. Bur. Stand. 69C, 283 (Oct. - Dec.).

Dmitrenko, I. M., et al, Thermometric characteristics of semiconductor diodes, Instr. Exp. Tech. (USSR), No. 5, 1288 (Sept. - Oct.).

Dockalek, A., and A. S. Popova, A thermistor thermometer with a liner scale and exchangeable temperature ranges, $\mathrm{Vy}$. Slaboproudy $\mathrm{Obz}$. 26, No. 10,596 .

Edelstein, A. S, and K. W. Mess, Reproducibility of carbon resistors used as thermometers below $1^{\circ} \mathrm{K}$, Physica 31, 1707 (Nov.).

Gaulle, G. K. et al, B10/Bll thermistor pairs and their application, Boron-Preparation, Properties, and Application 2, 317; AD-629523.

Goodall, D. H. J., The measurement of temperature in the range 3 deg $K$ to $80 \mathrm{deg} K$ using carbon resistors, Culham Lab., United Kingdom Atomic
Energy Authority, Abingdon NSA 20-19721 (Sept.).

Gordon, J. E., and L. I. Amstutz, A brass thermometer for use in determining temperatures below $1^{\circ} \mathrm{K}$, Cryogenics 5, No. 6, 329 (Dec.).

Hammond, D. L., C. A. Adams and P. Schmidt, A linear, quartz-crystal, temperature sensing element, ISA Trans. 4 , No. 4, 349 (Oct.).

Hardy, D., Lead life characteristics of Keystone's type AL3013-194.9-77-S1 thermal resistor, International Business Machines Corp., Oswego N. Y., Rept. No. 6100; AD-487104L (Aug. 12).

Kocher, R. M., et al, Simplifying large cryogenic research tankage temperature measurements, Advan. Cryog. Eng. 11, 189.

Melehy, M. A., Theory of a linear semiconductor thermometer, General Dynamics Corp., Groton Conn. Electric Boat Div., Rept. No. U417-65-034 $A D-475269$ (Sept.).

Morokh. A. M., and N. G. Mikhailus, Quartz resistance thermometer, Meas. Tech., (USSR) 7, 63 (July) .

Orlova, M. P. et al, New commercial resistance thermometers, Meas. Tech. (USSR) 11, 1001 (Nov.)

Pippin, C. A., A study of thermistor stability, Rocky Flats Div., Dow Chemical Co., Golden, Colo., RFD-649; NSA 20-11062; N66-26787 (Dec. 14).

Rafalowicz. J., Carbon resistors in low-temperature thermometers, Postepy Fiz, 16, No. 5, 603.

Rafalowicz, J., and B. Sujak, The physical meaning of calibration equations for standard carbon thermometers, Acta Physiol Polon. 28, No. 1, 55 .

Robertson, D., Resistance thermometry and the temperature standards laboratory, Proc. Instr. Soc. Am, 20, Part I, Paper No. 14.3-2-65.

Rubashko, V. Ya., Accounting for errors contributed by a thermistor in measuring temperature, Meas. Tech. (USSR) 10,966 (Oct.).

Shephard, G. G., Static response characteristics for a carbon bolometer, J. Appl. Phys. 36, 3300 (Oct.).

Stefanov, D., et al, X-ray structural studies of thermistors obtained from the thru-component systems $\mathrm{Mn} \mathrm{O}_{2}-\mathrm{Ni}_{2} \mathrm{O}_{3}$ and $\mathrm{Mn} \mathrm{O}_{2}-\mathrm{Ni}_{2} \mathrm{O}_{3}-\mathrm{ZnO}$, Izv. Fiz. Inst. s Aneb., Bulgar. Akad. Nauk. 13, No. 1,185 .

Sterling, J. J., Thermistor response time determinations in the self-heated mode, under conditions of fluid flow, Proc. Instr. Soc. Am. 20, No. 3, Paper No. 13.2-4-65. 
Suzuki, T., Silicon $p-n$ junction electr $\overrightarrow{i c}$ thermometer, Proc. Fujihara Mem. Fac. Eng. Keio Univ. (Tokyo) 18 , No. $70,55$.

Volkov, V. G., et al, High-frequency resistance thermometer, Priborostroenie 8, No. 5, 131.

Werner, F. D., and R. Keppe1, Total temperature probe, U. S. Patent 3,170,328 (Feb. 23).

Westhoff, G., Precise measurements with resistance thermometers, Energie 17, No. 12, 542.

Thin film thermistors, Interim development report Sept. 28 - Dec 23, Victory Engineering Corp., Springfie1d, N. J.; AD-484190.

Thin film thermistors, Interim development report Mar., Victory Engineering Corp., Springfield, N. J. ; $A D-485373$.

Thin film thermistors, Interim development report June 22 - Sept. 27, Victory Engineering Corp., Springfield, N. J., N66-17031; AD-624465.

Components irradiation test No. 17: resistance thermometers at liquid hydrogen temperatures, Lockheed-Georgia Co., Marietta, NASA-CR-74358; NSA 21-8661; N66-23672 (Nov.).

\section{6}

Ahlers, G., and J. P. Macre, Temperatureresistance relation for germanium thermometers, Rev. Sci. Instr. 37, No. 7, 962, (Ju1y).

Alieva, F. Z., Stability of the platinum resistance thermometer at high temperatures, Com. Int. Poids Mes. Sess., 7th Paris 1964.

Austin, E. L., Platinum temperature sensors, North American Aviation, Inc., Space and Information Systems Div., Downey, Calif. For copies Headquarters, Space Systems Div., Attn: IDEP Office, SSSD. Air Force Unit Post Office, L. A., Calif. 90045; AD-810 383L (June) .

Ballard, H. N., Response time of the effects of radiation on the Veco bead thermistor, Prepared at Texas Western College, El Paso, Texas; Schellenger Research Labs.; Contract No. DA-29-040-ORD-2410; N67-28961; AD-645050 (Aug.).

Barthe1t, H. P., et al, Investigation of thermistors, Report No. DLR-FB 66-72; N6719266; (Apr.).

Be11, E. C., and L. N. Hulley, Precision temperature control, IEE Proc. 113, 1671, (Oct.).

Berry, R. J., Effects of impurities on platinum resistance thermometers, Com. Consult. Thermom. Com. Int. Poids Mes., Sess., 7th Paris 1964, p. 40 .

Berry, R. J., Platinum resistance thermometry in the range $630-900^{\circ} \mathrm{C}$, Metrologia 2, No. 2, 80, (Apr.).
Bloss, W. R., Qualification of thermistors. Resis tor, fixed, thermal, metal encased, $720 \mathrm{MW}$. Eastman Kodak Co., Rochester, N. Y., Report No. TR-180D; AD-810 081L; (Aug.).

Bruce, H., Improved construction of resistance thermometer spear, J. Sci. Instr. 43, No. 8 , 608 , (Aug.).

Chandon, H. E., et a1, Cryogenic measurement with standardized rtt's, ISA J. 13, No. 1, 47, (Jan.).

Clairborne, L. T., et al, Low temperature germanium resistance thermometry, Rev. Sci. Instr. 37, No. 10,1422 , (Oct.).

Cohen, B. G., et al, Diffused germanium resistors for thermometry in 20 to $70^{\circ} \mathrm{K}$ range, Rev. Sci. Instr. 37, No. 12, 1689, (Dec.).

Craig, P. P., On the carbon resistance thermometry relation of Consolo, Santini, and VicentiniMissoni, Cryogenics 6, No. 2, 112, (Apr.).

Crockett, W. R., A new design approach for widerange temperature monitoring and compensating networks in scientific satellites, National Aeronautics and Space Administration, Goddard Space Flight Center, Greenbelt, Md. NASA-TN-D3617; N66-37154.

Donnini, J. M., J. Danoy, and P. Pesteil, Simple measurement of temperatures from 4 to $300^{\circ} \mathrm{K}$., Rev. Phys. App1. 1, No. 4, 262, (Dec.).

Drews, William A., Thermistor arrangement to improve temperature measurements at high altitudes, Sci. Tech. Aerospace Rept. 4, No. 18, 3549, Rept. No. NASA-CR-533; N66-31856 (Aug.).

Edlow, M. H., and H. H. Plumb, Reproducibility of germanium resistance thermometers at $4.2^{\circ} \mathrm{K}, \mathrm{J}$. Res. Nat. Bur. Stand. 70C, No. 4, 245, (Oct. Dec.).

F1ippen, R. B., Magnetic heating effects in carbon resistor thermometers at low temperatures, Cryogenics 6, No. 2, 114, (Apr.)

Froeme1, J. G., Thin film resistors, Victory Engineering Corp., Springfield, N. J. Final development report; Project No. SR-008-03-02, Task: 9598 (Oct.) .

Gooda11, D. H. J., The measurement of temperature from $3^{\circ} \mathrm{K}$ to $80^{\circ} \mathrm{K}$ using carbon resistors, U. $\mathrm{K}$. At. Energy, Authority Res. Group, Rept., Culham Lab. CLM-R47.

Hardin, W. R., and N. G. Einspruch, Calibration of Ga-doped Ge low temperature thermometers, Ann. Acad. Sci. Fennicae Ser. AVI No. 210, p. 49.

Herder, T. H., et al, Diffused semiconductor low temperature thermometers, Rev. Sci. Instr. 37 , No. 10, 1301, (Oct.). 


\section{Resistance Devices}

Hind, A. D., Temperature connections to a bead thermistor in the upper atmosphere, Weapons Research Establishment, Salisbury, Australia, WRE-PAD-121; N66-35293.

Hosek, J., and M. Pospisil, Thermistor thermometer, Chem. Prumysl 16, No. 6, 372.

Hughes, L. S., Use of thermistor-thermometer in determination of specific conductance, U. S. Geol. Surv., Water Supply Paper, 1822, 66.

Johnston, J. S., Recent advances in industrial resistance thermometry, Platinum Metals Rev. 10, No. 2, 43, (April).

Kolomaznik, K., Some properties of thermistor - materials in the system of oxides of $\mathrm{Mn}-\mathrm{Ni}-\mathrm{Cu}$, Silikaty 10 , No. 1,48 .

Kozhukh, V. Ya., Computation of circuits with thermistors for remote measurement of temperature, Meas. Tech. (USSR) No. 1, 88, (Sept.).

Malov, D. I., and L. S. Smagar, Thermometer for the continuous measurement of the high-frequency fields, Elektromekhanika $\underline{9}, 581$.

McLaren, E. H., and E. G. Murdock, Radiation effects in presision resistance thermometry, I. Radiation losses in transparent thermometer sheaths, Can. J. Phys. 44, No. 11, 2631 (Sept. - Dec.).

McLaren, E. H., and E. G. Murdock, Radiation effects in precision resistance thermometry, II. Illumination effect on temperature measurement in water triple-point cells packed in crushed ice, Issued as National Research Council (Ottawa, Can.) N.R.C. No. 9156 (Nov.); Can. J. Phys. 44, No. 11, 2653 (Sept. Dec.).

McMurtry, C. H., et al, Tin oxide thermistor for temperature sensing to $1800^{\circ} \mathrm{F}$, I.E.E.E. Trans. $\underline{2}, 461$, (Nov.).

Meaden, G. T., An $\alpha$-manganese resistance thermometer for the measurement of low temperature, Cryogenics 6 , No. 5, 275, (Oct.).

Mendelsohn, L. I., et al, Preparation and properties of positive temperature coefficient thinfilm thermistors, Am. Ceram. Soc. Bull. 45, No. 9,771 .

Mihele, V., Transistorized apparatus for stabilization and measurement of temperatures at very many points in several regions, Stud. Cercetari Fiz. 18, No. 6, 773 .

Mikheer, V. F., et al, Thin-film resistance thermometer for recording temperature on a propellant surface during rapid heating, Fiz. Goreniya Vzryva No. 2, 44 .

Moore, D. B., Thermistor as combination liquid level and temperature sensor, Rev. Sci. Instr. 37, No. 8, 1089 (Aug.).
Mroz, E. J., Qualification of victory engineering thermistors, Ratheon Co., Andover, Mass. For. copies: Army IDEP Office, Attn: AMSMI-RBP. Redstone Arsenal, Ala. 35809; AD-816-904L (July).

Nakaya, S., and H. Uchiyama, Thermometry of high temperatures with the aid of a platinum resistance thermometer, Com. Consult. Thermom., Com. Int. Poids Mes., Sess. 7th, Paris 1964.

Orlova, M. P., et al, New commercial resistance thermometers, Meas. Tech. (USSR) 11, 1001, (Apr.).

Orlova, M. P., et al, Alloyed germanium for lowtemperature thermometry, Meas. Tech. (USSR) 1, 82 , (Jan.).

Osborne, D. W., H. E. Flotour, and F. Schreiner, Precise low-temperature colorimetry with germanium resistance thermometers, Ann. Acad. Sci. Fenn., Ser. AVI No. 210,35 .

Powers, R. S., Comparison of Langmiur probe and spectrometric electron temperature measurements, J. App1. Phys. 37, 3821, (Sept.).

Puchades, J. B., Thermistor thermometers, Afinidad 23, No. 242, 125 .

Rafelowicz, J., E. Pega, and B. Sujak, On the possibility of the use of technical polycrystalline silicon in low temperature thermometry (Helium temperatures), Acta. Physiol. Polon. 30, No. 6, 1053 (Dec.).

Ramsdale, D. J., Theoretical time constant for the thin film temperature sensor, Texas Western College, Schellenger Research Labs., El Paso, Texas; Contracc: DA-29-040-AMC-1507 (X); AD816-412 (Oct.).

Robertson, E. C., et al, Properties of thermistors used in geothermal investigations. Preparation of thermistor cables used in geothermal investigations, Geological Survey, Washington, D.C. Geol. Surv. Bull: 1203-B.C; N66-35748.

Rubashko, V. Ya., Accounting for errors contributed by a thermistor in measuring temperature, Meas. Tech. (USSR) No. 10, 966 (Apr.).

Sartori, S., Stability of platinum resistance thermometers from $0^{\circ}$ to $630^{\circ}$, lst. Termometrico Italiano, Turim, Ric. Sci. 36, No. 11, 1276, (Nov.).

Sauer, H. J., et al, Induction field effects on temperature transducers, ISA J. 13, No. 3, 44 (Mar.).

Schriempf, J. T., Comparison of equations ror germanium resistor thermometry in the $2-.0^{\circ} \mathrm{k}$ range, Cryogenics 6 , No. 6,362 , (Dec.).

Schulte, E. H., Carbon resistors for cryogenic temperature measurement, Cryogenics 6 , No. 6 , 321, (Dec.). 
Sostman, Henry E., Resistance thermometers, Instr. Control Systems 39, No. 10, 117, (Oct.).

Szebeni, P., Low temperature measurements using semiconductors, Hiradastech. Ipari Kut Intez Kozlem $\underline{6}$, No. 2, 59.

Terrell, W. T., and W. T. Benecki, Tin oxide thermistor for temperature sensing to $1800^{\circ} \mathrm{F}$, Trans. Ind. Gen. Appl. IGA-2(6), 461.

Thompson, D. C., and D. P. Keily, The accuracy of thermistors in the measurement of upper air temperature, Am. Meteorological Soc. and Ar. Inst. of Aeronautics and Astronautics, Conference on Aerospace Meteorology, Los Angeles, Calif., Paper 66-386, (Mar. 28 - 31).

Thompson, D. C., The accuracy of miniature bead thermistors in the measurement of upper air temperatures, Mass. Inst. of Tech., Dept. of Meteorology Cambridge, Mass. Interim report Rept. No. Scientific-1 Contract: AF 19(628)-41 65; Proj: AF-6670; Task: 667001; AD-643-684 (Oct.).

Unsworth, J., and A. C. Rose-Innes, Silicon p-n junctions as low temperature thermometers, Cryogenics 6, No. 4, 239, (Aug.).

Wolff, E. G., and F. M. Viles, Semi-conductors for high temperature thermometry, Avco Corp., Research and Development Div. Final report Contract: AF 33(615)-1863; Proj: AF-8224; Task: 822404; AD 480105 (Jan.).

Components irradiation test No. 17: Resistance thermometers at liquid hydrogen temperatures, Lockheed-Georgia Co., Marietta, Georgia; NASA-CR-74358; N66-23672.

Diamond turns talents to thermometers, Iron Age 198,60 (Dec.).

Improved resistance thermometer bridge, Instr. Control Systems 39, 109 (May).

Thermistor thermometers, Instr. Control Systems, 39, 135 (May).

Thin film thermistors, Victory Engineering Corp., Springfield, New Jersey Interim Development Report Contract: NOBSR-93292; Proj: SR-00-0302; Task: 9598; AD-485 373 (Mar.).

\section{7}

Amundsen, T., The magnetoresistances of AllenBradley carbon thermometers, Cryogenics 7 , No. 6, 368 (Dec.).

Ashkinazi, I. M., A. G. Ivanova, and D. F. Tartakovskii, Calculating deviations of the resistance thermometers' calibration from their calibration tables, Izmeritel Tekhn. (USSR) No. 12, 21 (Dec.).

Bansal, T. D., The platinum resistance thermometer standard of NPL, Get-Together on
Thermometry, NAT Phys. Lab., New Delhi, Pap. 1.10. (13 - 17 Feb.)

Berry, R. J., Platinum resistance thermometry below $10^{\circ} \mathrm{K}$, Metrologia 3 , No. 3, 53 (July).

Bogdan, L., and J. E. Garberoglio, Transient heat transfer measurement with thin-film resistance thermometers--fabrication and application technology, Cornell Aeronautical Lab. Inc., Buffalo, New York, Interim Bocumentary Repert., Report No. CAL-AE-2385 Y-1; Contract: F33615 67 C-1144; AD-816 181 (June).

Branca, F. P., New high-sensitivity quartz thermometers, Rev. Sci. Instr. 38, No. 11, 1644 (Nov.).

Bryce, C. H., and V. H. Hole, Measurement and control by thermistors, Part 1, Industrial Electronics 5, No. 7, 294 (July).

Buravoi, S. E., Quick-response radiation thermometer, Izv. Vysshikh. Uchebn, Zavedenii 10, No. 2, 102 .

Cadranel, S. N., Qualification tests on hot gas temperature transducers, DAC SCN 1B64968-1, Douglas Aircraft Co. Inc., Missile and Space Systems Division, AD-816 853L (Jan. 27).

Califano, F. P., and G. Vitale, Thermometric measurements using gallium arsenide semicon-1: ductor diodes, Alta Frequenza 36, 152 (Feb.).

Clark, J. A. and T. Kobatashi, Properties of thermistors, Mass, Inst. of Tech., Dept. of Mechanical Eng., Cambridge, Mass., Contract: DA-19-016-ENG-3204; Task: 1V025001A13001; AD-818 017 (May).

Cullar, J. M., Evaluation of Fenwal Electronics Inc. P/N JB32L6 thermistor, Bendix Corp., Missile Systems Div. Mishawaka, Ind., Report No. BMSD-6111; Contract: N00017-67-C-2212; AD-837 769L (Oct.).

Edlow, M. H., and H. H. Plumb, Germanium resistance thermometry in the range 2.1 to $5.0^{\circ} \mathrm{K}, \mathrm{J}$. Res. Nat. Bur. Stand, 71C, No. 1 , 29 (Jan. - March).

Emori, Y., Thin-film resistance thermometer, Chiba Daigaku Kogakubru Kenkyu Hokoku 18, No. $33,19$.

Froeme1, J. G., and M. Sapoff, Thin film thermistor temperature sensor, Victory Engineering Corp. Springfield, New Jersey, Project: DA-1-F025001-A-126; Task: 1-F025001-A-12603; AD-823 193 (Sept.).

Gapamandzhyan, S. S., Bathythermometer, Joint Pub1. Research Service, Wash. D.C., Methods and Instr. for Marine Research, "JPRS-39881"; "TT-67-30529"; 110; N67-22369 (Feb.)

Gardzilowicz, A., Stagnation temperature measurement in a nozzle flow of steam with 
condensation, Prace Inst. Maszyn Przepływowych 38, No. 13 .

Guhathakurta, S. R., Certain thermistor charace teristics of single crystals of tungstenite, Indian J. Phys. 41, No. 8, 618.

Ha11, J. A., Platinum resistance thermometry, GetTogether on Thermometry, Nat. Phys. Lab. New Delhi, Pap. 1.11 (13 - 17 Feb.).

Harruff, R. W., Linear temperature scales from thermistor sensors, Instrum. Technol. 14, No. 6, 59 (June).

Ifft, E., and A. I. Shal'nikov, Manufacturing method for super-conductive thermometers, Prib. Tekh. Eks. Engtrans, in Instrum. Exper. Tech. No. 4,967 (July - Aug.).

Isayev, I. L., et al, Temperature measurements of the ocean surface from a moving vessel, Joint Publications Research Service, Wash. D.C., Methods and Instr. for Marine Research "JPRS39881"; "TT-67-30529"; 80; N67-22366 (Feb. 13).

Jones, E. W., Two-point comparison, Instr. Control Systems 40 , No. 1,115 .

Karbe, Yu. V., and S. P. Takhtuev, Hot-wire anemometer for the measurement of temperature, velocity and direction of a gas flow, Prib. Sist. Upr. No. 11, 43.

Kos, J. F., H. Drolet, and J. L. Larmarche, High-precision indium resistance thermometers, Can. J. Phys. 45, No. 8, 2787.

Kucherov, N. V., Measurement of temperature and temperature differences by means of resistance thermometers, Gl. Geofiz. Observ, imeni A. I. Vocikova, Tr. No. 205, 164, A68-14923.

Logvinenko, S. P., and Yu. G. Bevza, Low temperature meter with semiconductor sensor, Izmeritel Tekhu. 1,42 .

Miftakhov, E. Z., B. A. Formin, and N. P. Koroleva, High-temperature manometric thermometer, Prob. Sist. Upr. No. $8,13$.

Miller, C. E., and T. M. Flynn, Problems of measuring transient temperature in cryogenic fluids, ISA Trans. 6, No. 2, 133, N68-16729 (Apri1).

Novikari, G. E., Production of thermistors from vanadium tetraoxide with ultra-high temperature coefficients of resistivity, Izu. Leningra. Elektrotekhu. Inst. No. 66, 177.

Osborne, D. W., H. E. Flotow, and F. Schreiner, Calibration and use of germanium resistance thermometers for precise heat capacity measurements from 1 to $25^{\circ} \mathrm{K}$. High-purity copper for inter-laboratory heat capacity comparisons, Rev. Sci. Instr. 38, No. 2, 159 (Feb.).
Pinchevskii, A. D., Designing resistance thermometers for measuring transient temperatures, Meas. Tech. (USSR) 10, 1208 (Oct.).

Richards, J. C., Sensitive thermistor thermometer, Electron Eng. 39, 674 (Nov.).

Rusling, R. Y., and S. Rykaczewski, Cryogenic temperature measurement system covers range from $1.5^{\circ} \mathrm{K}$ to ambient, Instrumentation 20 , No. $3,10$.

Sarver, C. E., and J. S. Blankemore, Thermal time constants of germanium thermometers at liquid helium temperature, Florida Atlantic Univ., Dept. of Physics, Boca Rotan, Fla., Contract: AF-AFOSR-1259-67; Proj: AF-9763; Task: 976302, Cryogenics 7, No. 5, 299, AD-664279.

Schwarz, F., and T. Falk, Immersed thermistor detector optimization program, Part I, Final engineering report, Barnes Engineering Co., Stamford, Conn., NASA-CR-94613; N68-24165 (May 31).

Shvets, A. D., An apparatus for obtaining temperatures from 4.2 to $0.30^{\circ} \mathrm{K}$, Cryogenics 7 , No. 5 , 294.

Stevens, D. W., High-resolution measurement of air temperatures and temperature differences, J. Appl. Meteorol.6, No. 1, 179 (Feb.).

Stong, C. L., A sensitive electronic thermometer used for making a study in micro-meteorology, Sci. Am. 216, No. 6, 135 (June).

Thompson, D. C., and D. P. Keily, Accuracy of thermistors in the measurement of upper air temperatures, J. App1. Meteoro1. 6, 380 (April).

Toenshoff, D. A., and E. D. Zysk, Birdcage resistance thermometer, Instr. Control Systems 40, No. 5, 109 (May).

Vasilevskaya, V. N., et al, Germanium resistance thermometer for temperatures of $20-77^{\circ} \mathrm{K}$, Poluprov. Tekh. Mikroelektron No. 2, 13.

Vorovskikh, Yu., et al, Magnetoelectric temperature gauges, Trianslated from Automob. Transp., 45, No. 1, 43; FSTC-HT-23-080-69; AD-688063; $\overline{\mathrm{N} 69}-37018$.

Weaving, G. S., A portable thermistor temperature integrator, J. Sci. Instr. 44, No. 1, 55 (Jan.).

Zaidel, Kh. E, and D. A., Samakovluski, Precision photogalvanometric resistance thermometer, Meas. Tech. (USSR) 6, 690 (June).

Zhokhov, A. D., and I. I. Gromova, Use of thermistors for measuring temperature fluctuation in the sea and improvement of technology of producing multijunction thermocouples, Joint Publications Research Service, Wash. D.C., Methods and Instr. for Marine Research, "JPRS39881"; "TT-67-30529"; 117; N67-22370, (Feb. 13) . 


\section{Resistance Devices}

Electrical resistance units, Toa Electronics Ltd., British Pat. No. 1,084,879 (9-27-67).

A transistor temperature sensor, Industrial Electronics 5 , No. 8, 357 (Aug.).

Measurement and control by thermistors, Part 2, Industrial Electronics $\underline{5}$, No. 8, 358 (Aug.).

Miniature thermometer sensor, Engineer (London) 224, 327 (Sept. 8).

Thermistors and their stability, Bell Astrosystems Co., Buffalo, New York; AD-831 238L (July).

Thermistor devices improve temperature measurement, Light. Prod. Engineering $\underline{5}, 20$ (Feb.).

Sensitive measurements of very low temperatures, Engineering (London) 203, 939 (Jan. 9).

\section{8}

Antcliffe, G. A., et al, Germanium resistance thermometry at temperatures below $1^{\circ} \mathrm{K}, \mathrm{Rev}$. Sci. Instr. 39, No. 2, 254 (Feb.).

Barran, S., and W. S. Rautio, Thermistor theory and special applications, Instr. Control Systems 41, No. 10,83 (Oct. 18).

Bertman, B., An ALGOL program for calibrating resistance thermometers at low temperatures, Duke Univ., Dept. of Physics, Durham, N. C., Contract No. DA-ARO- (D)-31-124-G895; AD-686 981 .

Brodskii, A. D., Simplified method for calibrating commercial platinum resistance thermometers in the range of $12-90^{\circ} \mathrm{K}$, Meas. Tech. (USSR) 4, 455 (Apr.).

Bulanova, L. K., et al, Some results from a new method for measuring temperature in the high atmospheric layers with microthermistors, Joint Publication Research Service, Washington, D.C. ; JPRS-46726; N69-10252, (Oct. 22).

Cassidy, E. C., S. Abramowitz, and C. W. Beckett, Investigation of the exploding wire process as a source for high temperature studies, Nat. Bur. Stand. 109, Washington, D.C., U.S. Dept. of Commerce.

Clark, R. D., A simplified equation for calculation of small temperature difference from resistance thermometer measurements, J. Sci. Instr. $\underline{2}$, No. 1, 785 (July).

Culbert, H. V., and Z. Sungaila, Calibration of a resistance thermometer down to $0.4 \mathrm{~K}$ using a specimen of known heat capacity, Cryogenics $\underline{8}$, 386 (Dec.).

Curtis, D. J., and G. J. Thomas, Long term stability and performance of platinum resistance thermometers for use up to $1063^{\circ} \mathrm{C}$, Metrologia 4 .

Dean, J. W., and R. J. Richards, Hydrostatic pressure effects in carbon and germanium thermometers Advan. Cryog. Eng. 13, 505, NASA Contract No. $\mathrm{R}-45$.
Deodhar, M. G., anc C. L. Toshniwal, Use of diode for measurement of temperature, J. Inst. Engrs. (India) 48 , No. 9, 689 (May).

Dimarov, Ye. N., High temperature thermistors based on system $\mathrm{ZnO}-\mathrm{NiO}-\mathrm{Fe}_{2} \mathrm{O}_{3} ;$ Air Force Systems Command, Wright-Patterson AFB, Ohio; N68-37318 (Aug.).

Drake, J. C., and R. D. Moyer, Measurement of thermistor mount calibration factor by a comparison method, Sandia Corp., Albuquerque, New Mexico, Report No. PB-183839; N69-41382 (Dec.).

Fabula, A. G., Theoretical frequency response of stagnation region thin-film thermometers, J. Sci. Instr. (London) Series 2, 1, 1200 (Dec.).

Fabula, A. G., The dynamic response of towed thermometers, Naval Undersea Warfare Center, Pasedena, California, J. Fluid Mech. (G. B.) 34, Part 3, 449 (Dec. 2)

Furman, N. I., et al, Remote measurement of the temperature of the flushing liquid during drilling of deep holes, Mining Thermophysics, 93; N70-16598.

Gerber, R., A platinum resistance thermometer for measurement of low temperatures, Cesk. Casopis Fys. 18, No. 1, 94 .

Gonda, S., Sintered resistors for low-temperature thermometry, Electrotech. Lab., Tokyo, Japan, Denki Shikensho Iho $\underline{32}$, No. 12, 1184.

Hetzler, M. C., and D. Walton, New interpolation formula for carbon resistance thermometry, Rev. Sci. Instr. 39, No. 11, 1656 (Nov.).

Holm, K., Thermistor thermometer based on a stable multivibrator, Electron. Eng. 40, 700 (Dec.).

Harget, P. J., and D. T. Sturgill, Method for making thermistors, Queens-Illinois Inc., U.S. Patent No. 3,393,448 (CL.29-612) (July 23).

Hudson, W. R., Negative magnetoresistances in carbon resistance thermometers, Rev. Sci. Instr. 39, No. 2, 253 (Feb.).

Hughes, B. A., On the characteristics and measurement of towed platinum thermometers, Defense Research Establishment, Pacific, Victoria B. C., Report No. DREP-TM-68-14; AD-852812 (Sept.)

Hyson, P., The tungsten wire temperature sensors, J. Appl. Meteorol. 7, 684; A68-41777 (Aug.).

Jahr, K. F., G. Wiese, and G. Schuchardt, Highsensitivity temperature measuring device for cryoscopic measurements and thermometric titrations, Freie Univ. Berlin; Berlin, Germany, Z. Physik Chem. 61, No. 1, 73 .

Johnston, W. V., and G. W. Lindberg, Stability and calibration of miniature platinum resistance thermometers, Rev. Sci. Instr. 39, No. 12, 1925 (Dec.). 
Kaufman, E., Instantaneous temperature sensor, Instr. Control Systems 41, No. 5, 89 (May).

Keily, D. P., Radiation balance in rocketsonde thermometers, Massachusetts Inst. of Tech., Cambridge, Dept. of Meteorology, Final Report, Contract AF 19(628)-4165; AFCRL-68-0410; Avail. CFSTI; AD-677343; N69-14155 (Feb.).

Kennedy, B. W., et al, Thin film temperature sensor, Atmospheric Sciences Lab., White Sands Missile Range, New Mexico, Prepared in cooperation with Texas, Univ., El Paso, Texas; Schellenger Research Laboratory; Task 1P650212A127-03; $\mathrm{AD}-669747$; N68-30415 (Mar.).

Kuehn, L. A., and R. S. Weaver, A system for recording temperatures in the vicinity of liquid surfaces, J. Sci. Instr. (G. B.) Series 2, 1, 776; AD-667 127 (July).

Landiya, N. A., N. G. Lezhava, and G. D. Chachanidze, Use of thermistors in high-temperature calorimetry and their calibration, Teplo. Vys. Temp. (USSR) 6, No. 2, 298 (March).

Machiguki, T., and S. Sawada, Oxygen point calibration of a platinum thermometer by intercomparison, Oyo Bursuri 37, No. 2, 157.

Maker, F. J., A sensitive thermometer, J. Sci. Instr. (G. B.) Series 2, 1, 584 (May).

McCoa, D. J., Measurement of film thickness of thin film resistance thermometers, AIAA J. 6, 747 (April)

Mishin, V. E., Thermal inertia of a thermistor acting as a temperature sensing element, Kazanski: Aviatsionnyi Institut, Trudy, Raboty Aspirantov; Soiskatelei, 103, 40; A69-38888.

Moussa, M., H. Van Dijk, and M. Durieux, Comparison of platinum resistance thermometers between $63^{\circ}$ $\mathrm{K}$ and $373.15^{\circ} \mathrm{K}$, Kamerlingh Onnes Lab., Leiden, Netherlands, Physica 40 , No. 1, 33 .

Owston, C. N., Application of thermistors to optical pyrometry and temperature control, Dept. Materials, Coll. Aeronautics, Cranfield, Bedford England, J. Sci. Instr. (G. B.) Series 2, 1, No. 12, 1128 (Dec.).

Petrov, P., and S. Ivanov, Thermistors with negative temperature coefficients from the manganese (III) oxide-nickel (II) oxide copper (I) oxide system, Izu. Fiz. Inst. ANEB, Bulgaria, Akad. Nauk. 17, 33, Bulgaria.

Pravoverov, N. L., R. M. Babaev, and V. I. Tikhanov, High temperature thermistor from polycrystalline baron, Prib. Sist. Upr. 2, 43.

Raja, J., and P. E. Sankaranarayanan, A resistance thermometer for measuring air temperatures, J. Sci. Instr. (G. B.) Series 2, 1, 150 (Feb.).

Sapoff, M., and J. G. Fraemel, Method of making a thermistor, Victory Engineering Corp., U.S. Patent No. 3,364,565 (Cl.29-612) (Jan. 23).
Sinclair, D. H., H. G. Terbeek, and J. H. Malone, Cryogenic temperature measurement using platinum resistance thermometers, NASA Lewis Research Center, Cleveland, Ohio, NASA-TN-D-4499; N6820324 (Apr.).

Smeathers, P. R., Semiconductor diode thermometer, Cryogenics 8, 393 (Dec.).

Stutheit, J. S., Fast-response gamma-thermometers, Nucl. Instr. Methods 63 , No. 3, 300.

Terry, C., Self supporting carbon resistance thermometers for use at low temperatures, Rev. Sci. Instr. 39, No. 6, 925.

Thompson, D. C., Aerodynamic heating of miniature head thermistor thermometers in a rarified airstream, J. Ap. Meteorology 7, 504 (June).

Van Dijk, H., M. R. Moussa, and M. Durieux, Comparison of platinum resistance thermometers between $63^{\circ} \mathrm{K}$ and $373.15^{\circ} \mathrm{K}$, Kamerlingh Onnes Lab., Leiden, Neth., Physica $\underline{40}$, No. 1, 49.

Veprek, J., Carbon and semiconductor sensors for very low temperatures, Ceskoslov. Avad. Ved., Brno, Czech., Slaboproudy Obzor. 29, No. 7, 407.

Verster, T. C., P-N junction as an ultralunar calculable thermometer, Electron. Letters 4, 175 (Republic of South Africa) A68-29575 (M̄ay 3)

Vinetskii, R. M., et al, Application of germanium alloyed with gallium and zinc to lowtemperature thermometry, Inst. Napivprov., Kiev. (USSR) Ukr. Fiz. Zh. 13, No. 6, 1052.

Yet-Chong, C., and A. M. Forrest, A platinum resistance thermometer calibration between $2^{\circ} \mathrm{K}$ and $273.15^{\circ} \mathrm{K}$, School Physical Sci., Univ. St. Andrews, Scotland, J. Sci. Instr. (G. B.) Series 2, 1, No. 8, 839 (Aug.).

Probe, thermistor, (isotherm), Fenwal Electronics Inc., Sert 11; AD-873 987L (June).

Texas Instruments thermistor, design appraisal report, Boeing Co., Seattle, Washington; $\mathrm{AD}-$ $856146 \mathrm{~L}$ (Oct.).

Delta semiconductors; thermistors, design appraisal report, Boeing Co., Seattle, Washington; $\mathrm{AD}-851$ 605L (Oct.).

Thermistor reads patients fever as an electronic signal, Prod. Eng. 39, 82 (Mar. 11).

Platinum-resistance thermometer, Engineer, (Londar) 225, 409 (Mar. 8).

Taking tyre (tire) temperatures, Engineering, (London) 205, No. 5330, 896 (June 14).

Tire temperature tests conducted at N. B. S. use improved thermistors, Rubber Age 100, 130, (May) . 
Alon, Y., and M. Jonas, Thermistor thermometer for linearized magnetic recording and telemetry, Rev. Sci. Instr. 40, No. 5, 646; A69-29562 (May).

Adby, P. R., A wide range cryogenic thermometer, J. Sci. Instr. 2, No. 2, 817 (Sept.) .

Belanger, B. C., The behavior of carbon resistor thermometers in magnetic fields up to $100 \mathrm{k0e}$ in the pumped liquid helium and hydrogen temperature ranges, Rev. Sci. Instr. 40, No. 8, 1082 (August).

Belyansky, L. B., et al, Investigation of the resistance-temperature properties of platinum for resistance thermometry over the range from $90 \mathrm{~K}$ to $273 \mathrm{~K}$, Metrologia 5, No. 4, 107 (Oct.).

Booth, B. L., and A. W. Ewald, Fabrication of extremely small carbon resistor thermometers, Rev. Sci. Instr. 40, No. 10, 1354 (Oct.).

Borcherds, P. H., Sensitivity of carbon resistance thermometers, Cryogenics 9, 138 (Apri1).

Branca. F. P., On the sensitivity of a new quartzthermometer and its parameters, Rec. Sci. 38, No. 6, 600 (June).

Culbert, H. V., and Z. Sungaila, Calibration of a resistance thermometer down to $0.4 \mathrm{~K}$ using a specimen of known heat capacity, Cryogenics (G.B.) 8, No. 6, 386 (Dec.).

Dail, H. W., and G. S. Knapp, Accurate temperature measurements on a microbalance suspension by inductive coupling, Rev. Sci. Instr. 40, No. 8, 1086 (Aug.).

Diamond, J. M., Extensions of Callendars equations for platinum resistance thermometry, Rev. Sci. Instr. 40, No. 11, 1477 (Nov.).

Dutt, M., On the measurement of average temperature in circular ducts, ISA Trans. 8 , No. 2, 98.

Feidt, R., et al, Thermistor thermometer with low energy dissipation intended for measurement in a flowing fluid, Academie des Sciences, (Paris) Conptes Rendus, Serie A-Sciences Mathematiques 268, No. 16, 899; A69-30296 (Apr. 21).

Gill, D., et al, Precision thermometer for the region 10-40K, Rev. Sci. Instr. 40, No. 1, 109 (Jan.).

Hormuth, G. A., Resistance thermometers for precision temperature measurement, Mach. Des. 41 , 136; A69-35840 (July 10).

Kennedy, B. W., Thin film temperature sensor, Rev. Sci, Instr. 10, No. 9, 1169 (Sept.).

Lang, S. B., et al, Pyroelectric thermometer for use at low temperatures, Univ. California, Livermore, Rev. Sci. Instr. 40, No. 2, 274 (Feb.) .
London, A. L., and D. V. Nelson, A new dimension in hydraulic machinery testing with the quartz crystal thermometer, Stanford Univ., California Dept. of Mech. Eng.; AD-695400; N70-16499

(Aug.).

Lorenz, R., and J. W. Fogwel1, Digital thermometer, Part 2, Final Report, Southwest Research Inst., San Antonio, Texas, NASA-CR-108423; N70-28157 (Nov.).

MacDonald, F. R., Self-heated thermistor circuits, Instr. Control Systems, 42, No. 10, 100 (Oct.).

Maslov, V. S., Possibility of using semiconductor diodes for measuring temperature, Izdatel stvo Naukova Dumka, 113; A69-18556.

Mendelsohn, L. I., E. D. Orth, and R. E. Curran, Preparation and properties of unsupported positive coefficient, thin thermistor films, J. Vacuum Sci. Technolo. 6, 363, A69-41214 (May June) .

Mezhov-Deglin, L. P., and A. I. Shal'Kikov, Low heat capacity carbon thermometers, Cryogenics 9, 60 (Feb.).

Muijlwijk, R., Determination of temperatures below $14 \mathrm{~K}$ with platinum thermometers, Kamerlingh Onnes Lab., Leiden, Netherlands, Physica 43 , No. 3, 419 (July 29).

Muijlwijk, R., M. Durieux, and H. Van Dijk, Comparisons of platinum resistance thermometers with the hydrogen vapour-pressure thermometer, Kamerlingh Onnes Lab., Leiden, Netherlands, Physica 43, No. 4, 622 .

Neuringer, L. J., and Y. Shapira, Low temperature thermometry in high magnetic fields, I., carbon resistors, Rev. Sci. Instr. 40 , No. 10, 1314; AD-698663 (Oct.).

Novopavlovskii, V. S., The error of measurement of a surface temperature by a resistance thermometer, National Lending Library for Science and Technology, Boston Spa Eng., NLL-RTS-5097; N69-27875 (May).

Pellinets, V. S., Remote testing of resistance thermometers, Meas. Tech. (USSR) 5, 651 (May).

Praddaude, H. C., Interpolation formula for gallium arsenide $\mathrm{p}-\mathrm{n}$ junction diode thermometer in the 1 to $100^{\circ} \mathrm{K}$ range, Mass. Inst. of Tech., Cambridge, Mass., Rev. Sci. Instr. 40, No. 4,599 .

Pratt, J. P., and D. C. Ailian, New two-point calibration method for platinum resistance thermometers for the range $75-400 \mathrm{~K}$, Rev. Sci. Instr. 40, No. 12, 1614 (Dec.).

Robichaux, J. E., and A. C. Anderson, Modified Speer resistors for use as low temperature thermometers, Rev. Sci. Instr. 40, No. 11, 1512 (Nov.). 
Rosenbaum, R. L., Some low temperature thermometry observations, Rev. Sci. Instr. 40, 577 (Apr.).

Sabinin, K. D., Determining the parameters of internal waves by Jato from towed thermistor chains, in Fiz. Atm. i Okeana, 5, No. 2, 1; JPRS-47889; N69-2499913-13 (Apr. 21).

Schaible, P. M., and L. I. Maissel, Thin-film maximum thermometer, Thin Solid Films $\underline{3}$, No. 4, 277.

Schlosser, W. F., and R. H. Munnings, Thermistors as temperature sensors at $4.2 \mathrm{~K}$ and the effect of a magnetic field, Rev. Sci. Instr. 40, No. 10, 1359 (Oct.).

Schmidt, B., Technology of Vanadium thermistors, Arch. Elektrotech 18, No. 2, 405; A69-36718.

Sharevskaya, D. I., et al, Investigation of the resistance-temperature properties of platinum for resistance thermometry over the range from $14 \mathrm{~K}$ to $90 \mathrm{~K}$, Metrologia 5, No. 4, 103 (Oct.).

Star, W. M., J. E. Van Dam, and C. Van Baarle, Manufacture and precision interpolation of a film-type carbon resistance thermometer, Kamerlingh Onnes Lab., Leiden, Netherlands, J. Sci. Instr. (G. B.) Series 2, 2, No. 3, 257 (March).

Toscano, W. M., Radiation properties of thermistor beads, Mass. Inst. of Tech., Cambridge, Mass., Report No. SCIENTIFIC-1; AD-689805 (Feb.).

Van Dael, H., Manufacture of a film-type carbon resistance thermometer, J. Sci. Instr., 2, No. 10,910 .

Verster, T. C., Dual transistor as thermometer probe, Rev. Sci. Instr. 40, 174 (Jan.).

Wolff, E. G., Oxide thermistor for use to $2500 \mathrm{~K}$, Rev. Sci. Instr. 40, No. 9, 544; A69-26478

(Apr.).

Thermistor survey, Instr. Control Systems 42, No. 10, 95 (Oct.).

Mode1 U2104B IN-SITU thermometer, National Oceanographic Instrumentation Center, Washington D.C., Report No. IFS-70005; AD-873540L (Nov.). 
1964

Beattie, J. R., Application of radiation pyrometry to glass temperature measurement and control, Proc. Instr. Soc. Am. Ann. Conf. 19, (IV), Preprint No., 4.2-1-64.

Christenson, R. W. S., Environmental errors in use of the airborne infrared radiation thermometer to measure sea-surface temperature, Naval Post-graduate School, Monterey, Calif., Masters thesis; $A D-601473$.

Elder, S. A., and F. K. Hill, Measurement of heat transfer at nozzle throat by imbedded pyrometer method, Applied Physics Lab., Johns Hopskins Univ., Silver Spring, Md., TG-552; AD-631821; N66-29205.

Exton, R. J., A variable exposure photographic pyrometer, National Aeronautics and Space Administration, Langley Research Center, Langley Station, $\mathrm{Va}$., Presented at the 19th Ann. ISA Conf., NASA-TM-X-51702; CFSTI: HC; N65-21471.

Johnston, R. G., and R. P. Madden, On the use of thermopiles for absolute radiometry in the far ultraviolet, National Bureau of Standards, Washington, D. C., NASA Order R-73; NASA - CR64059; N66-33178.

Kandyba, V. V., Methods and instrumentation for measuring temperatures of flames, flowing gases, and plasmas, Intern, Meas. Conf., 3rd, Budapest, 2,359 .

Labuda, A. A., et al, Measurement of temperature in a pulse discharge, $\mathrm{Tr}$. Komis. Po., Spektroskopii, Akad. Nauk. SSSR, 2, No. 1, 434.

Lieneweg, F., Errors and effects in optical temperature measurements with total-radiation, monochromatic-radiation and two-color-radiation pyrometers, Arch. Eisenhuttenw 35, 1145, (Dec.).

Logan, C. A., and R. P. Johnson, Automatic temperature measurement as applied to a cement kiln, Proc. Instr. Soc. Am. Ann. Conf. 19, (IV).

Penzias, G. J., R. H. Tourin, and A. D. Dolin, Infrared techniques for air temperature measurements in a hypersonic wind tunnel, Warner and Swasey Co., Flushing, N. Y., Contract AF33 616 8319; Proj. 7065; Task 7065 02; ARL 64 170; A16-608 983 .

Svet, D. Ya, Relation of brightness temperature to total radiation temperature, High Temp. $\underline{2}$, No. 5, 717 (Sept. - Oct.).

Tskhai, N. S., Method for the determination of the kinetic temperature of a gas radiation, High Temp. 2, No. 2, 261 (Mar. - Apr.).
Bazilevskii, A. R., and R. V. Starov, The measurement of temperature of a converter blow with the PRK - 600 radiation pyrometer, Ind. Lab. 31, No. 11, 1708, (Nov. $)$.

Bernard, B., Flame temperature measurements, Instr. Control Systems 38, No. 5, 113, (May).

Boyarskii, L. A., and P. G. Strelkov, Reproducibility of the position of a temperature calibrated lamp on an optical bench of a spectropyrometer, Meas. Tech. (USSR) 8, 717 (Aug.).

Boyarskii, L. Ya., Polarization method of reducing luminance for reproducing high-temperature scales, Meas. Tech. (USSR) 10, 960, (Oct.).

Campanaro, P., et al, A black body simulator with automatic control of the temperature, Termotecnia 19, No. 12, 684, Italian (Dec.).

Dolgopolov, N. N., and S. G. Simonyan, Measuring the surface temperature of materials during high-frequency and acoustical drying, Ind. Lab. 31, No. 9, 1387 (Sept.).

Esser, F., Temperature measurement using optical pyrometers in the temperature range $700^{\circ}$ to $1200^{\circ} \mathrm{C}$, with reference to the emissive power of steel surfaces, Neue Hutte 10, 302, (May).

Exton, R. J., Theory and operation of a variable exposure photographic pyrometer over the temperature range $1800^{\circ}$ to $3600^{\circ} \mathrm{F}\left(1255^{\circ}-2255^{\circ} \mathrm{K}\right)$ STAR 3, No. 17, 2944, Rept. No. NASA-TN-D-2660; N65-2 $\overrightarrow{89} 16$.

Frazine, D. F., The design of a total radiation thermopile detector, Arnold Engineering Development Center, Arnold Air Force Station, Tenn., AEDC-TDR-64-271; Contract AF 40 (600)-1000, ARO Proj. SW3410; AD-453-973 (Jan.).

Galley, J., et al, New photoelectric pyrometer for industrial applications, Engrs. Dig. (London) 26, 91 (May).

Golub, L. M., et al, Method for extending the scale of a radiation pyrometer to the hightemperature range, Meas. Tech. (USSR) 10, 963, (oct.).

Grenis, A. F., and M. J. Matkovich, Blackbody reference for temperatures above $1200^{\circ} \mathrm{K}$, Sci. Aerospace Rept. 3, No. 17, 3033, N65-29022; $\mathrm{AD}-(614638)$.

Ho, C., and D. Duffey, Application of spectroscopic methods for measurements of plasma electron temperature and density, Advances in Plasma Dynamics: American Institute of Aeronautics and Astronautics, and Northwestern University, Biennal Gas Dynamics Symposium, 6th; Evanston, I11., August $25-27,1965$, Proceedings. [A6729034 14-25]; A67-29045.

Kadyshevich, A. E., Optical pyrometry of real flames, Opt. Spectr. 18, No. 6, 612, (June). 


\section{Radiation Devices}

Kogan, A. V., Optical Systems of pyrometers for measuring the temperature of small bodies, High Temp. 3, No. 5, 691, (Sept. - Oct.).

Kon, K., and 1. Eguchi, High-speed radiation pyrometer, Denki Seiko 36, No. 5, 219.

Kottenstette, J. P., Fast-response optical pyrometer, 1SA Trans. 4, No. 3, 270.

Krakow, B., Determination of hot-gas temperature profiles from infrared emission and absorption spectra, A.I.A.A. J. 3, 1359, (July).

Kustanovich, I. M., et al, Optical pyrometry of plasma jets, Kinetikai i Termodinam Khim. Reaktsii v Nizkotemperaturnoi Plazme, Akad. Nauk SSSR, lnst. Neftekhim. Sinteza, 2, 196.

Land, T., A memory unit for radiation pyrometers, Ind. Process Heat 5, 22, (Oct.).

Land, T., Metal temperature measurement, lnd. Process Heat 5,30 , (Sept.).

Lauver, M. R., J. L. Hall, and F. E. Belles, Shocktube gas temperature measurements by infrared snonochramatic radiation pyrometry, NASA-TN-D2955; N65-30899 (Aug.).

Lorenz, D., Measurement of ground surface temperature with the help of radiometers, Meteorol. Rdsch 18, No. 2, 40, (Mar. - Apr.).

Mann, K., An ir (infrared) solar-furnace pyrometer, Solar Energy 9 , No. 3, 136.

Molchanov, V. M., Use of an optical method for measuring temperature differences, Instr. Exper. Tech. No. 1, 165, (Jan. - Feb.).

Nettleton, M. A., Temperature measurements on burning coal particles in a radiating enclosure, Combustion \& Flame $\underline{9}$, No. 3,311 , (Sept.).

Peckham, G., et al, Remote temperature sensing of the earth's atmosphere using a selective chopper radiometer, Symposium on Electromagnetic Sensing of the Earth from Satellites, Univ. of Fla., Coral Gables, Fla. Proceedings 1965; A67-40350; (Nov. 22 - 24).

Poskachei, A. A., and M. P. Uralskii, Spectrum ratio pyrometer with a measurement range of 300 to $500^{\circ} \mathrm{C}$, lnstr. Construct. No. 4,8 (Apr.).

Poskachei, A. A., and M. P. Uralskii; Measuring surface temperature of aluminum and magnesium alloy products with Partial-emission pyrometers, 1nd. Lab. 31, No. 11, 1764, (Nov.).

Ristic, M. M., and D. Delic, Differential thermal radietion analysis, Proc. 1st lnternat. Conf. Thermal Analysis, Aberdeen 1965 (London: Macmillian, 1965).

Shakhtin, D. M., et al, More precise evaluation of the total correction in measuring temperature with optical pyrometers, Meas. Tech. (USSR) 12, 1190 (Dec.).
Sifner, 0. , Some optical methods for the measure: ment of high temperatures, Strojnicky Casopis $16,2,247$.

Svet, D. Ya., Comparison of classical methods of pyrometry for real bodies with a continuous emission spectrum, High Temp. 3, No. 3, 407, (May - June).

Van Ness, R. T., Infrared (IR) thermometers to measure polyethylene melt in-process, Plastics Technol. 11, No. 12, 30 (Dec.).

Verch, J., Analysis of optical-pyrometrical temp erature measurements, NASA-TT-F-9359; TT-6564268; N65-23794; (May).

Westhoff, G., Measuring of temperatures with radiation pyrometers, Energie 17, No. 10, 423.

Wnuk, S. P. Jr., Progress in high-temperature an radiation resistance strain-gage development, Exp. Mech. 5, No. 5, 27A (May).

Wright, M. A., Some spectroscopic methods of gas temperature measurement in the range $3000^{\circ}$ to $10,000^{\circ}$ K, B.C.U.R.A. (Mon. Bul1.) 29, 137, (May)

Yayshev, N. A., Heat-exchange formula for thermometers which takes into account heat removal and radiation, Meas. Tech. (USSR) 5, 411, (Nov.

Soviet Infrared sensors. 1. thermal sensors, Aerc space Technology Div., Library of Congress, Washington, D.C., Rept. No. ATD-P-65-44; TT 65 63277; AD-619-813 (Jul, 30).

New PEM cell pyrometer eases temperature measurement problems, Instrumentation 18 , No. 4, 33 .

Rocket base flow field studies using an electron beam probe, Quarterly progress Rept. No. 1, Cornell Aeronautical Lab., Inc., Buffalo, N.Y. NASA-CR-67880; N66-10619 (June 25 - Sept. 25).

Two color pyrometer spots temperature, Can. Chem. Process. 49, 77," (Nov.).

\section{6}

Babushkin, V. V., et al, Double optical pyrometer LO- 6 for the measurement of the temperatures and absorptivity of a body, Priborostroenie 1, 10 ,

Baker, E. J. Jr., Determination of surface temperature and emmisivity. Final Report, Southwest Research Inst., San Antonio, Tex.; N66-36011, (May).

Bazilevskii, A. R., and R. V. Starov, The measurement of temperature of a connector blow with the PRK-600 radiation pyrometer, Ind. Lab. 31, No. 11, 1708 (Apr. 1).

Bernard, B., Infrared temperature sensing of transparent objects, Instr. Control Systems 39 , 131, (May). 
Black, P. J. S., A pyrometer for the continuous measurement of the temperature of aluminum extrusions, J. Inst. Metals 94, 384 (Nov.).

Blackmon, W., Spectroradiametric blackbody calibration, Proc. Instr. Soc. Am. Ann. Conf. 21, 1966, Part 2, Paper 16.16-1-66.

Bolon, A. E., Surface-temperature distribution by infrared photography, Instr. Control Systems 39, 107 (May).

Branstetter, J. R., Some practical aspects of surface temperature measurement by optional and ratio pyrometers, National Aeronautics and Space Administration, Lewis Research Center, Cleveland, Ohio, NASA-TN-D-3604; N66-35648 (Sept.).

Briggs, C. W., Infrared sensors for glass temperature measurements, Instrumentation 19, No. 2 , 12.

English, P., and M. G. Dingle, Rapid scanning monochromator for use with line reversal temperature measurement, J. Sci. Instr. 43, No. 2, 121 (Feb.).

Euler, K. J., Measurement of true temperature by optical pyrometry, Chem. Ing. Tech. $\underline{38}$, No. 2, 154 (Feb.).

Frazine, D. F., The design and construction of thin film radiation thermopiles, Arnold Engin. Development Center, Arnold Air Force Station, Tenn., Tech. Report No. AEDC-TR-66-38; Contract: AD $40(600)-1200$; Proj. ARO-SW3410; AD-480 327 (Apr.).

Geery, E. L. et al, Nozzle tube-wall temperature measurement by radiometric techniques, J. Spacecraft Rockets 3, 1144 (July).

Goodbar, W. L., and P. E. Hamilton, Improved method for measuring turbine-varie temperature in hot Cascade-rigs, General Motors Corp., Indianapolis, Ind., Allison Div., In it's Volume No. 11, 3rd Quarter; N66-36003 (1966).

Griggs, M., and F. C. Harshbarger, Measurements of temperature profiles at the exit of small rockets, Appl. Opt. 5, No. 2, 211 (Feb.).

Hill, M. L., J. M. Akridge, and C. A. Keller, Miniature recording optical pyrometer, Applied Physics Lab., Johns Hopkins Univ., Silver Spring, Md., TG-825; AD-636101; N66-37253.

Hornbeck, G. A., Optical methods of temperature measurement, App1. Opt. 5, No. 2, 179 (Feb.).

Hovis, W. A. Jr., Optimum wave length intervals for surface temperature radiometry, Appl. Opt. 5, 815 (May).

Hunter, W. W., Rotational temperature measurements $300^{\circ} \mathrm{K}$ to $1000^{\circ} \mathrm{K}$ with electron beam probe, NASA-Langley, Langley Station, Va., ISA 21 st
Annual Conf, and Exhibit, NASA-TM-X-59966; N6827416 (Oct. 24 - 27).

Jona, F., and H. R. Wendt, Pyrometric measurements of $\mathrm{Si}, \mathrm{Ge}$, and GaAs wafers between $100^{\circ}$ and $700^{\circ} \mathrm{C}$, J. Appl. Phys. 37, No. 9, 3637

(Aug.).

Kaufman, W. C., and J. C. Pittman, Jr., Quantitative radiometric measurement of skin temperature, J. Appl. Physiol. 21, No. 1, 302; AD-635 718 (Jan.).

Klika, R., Measuring fuel and air temperature along the vertical walls of an open hearth furnace, Sbornik VSB Ostrava 12, No. 2, 315.

Kostkowski, H. J., A new radiometric equation and its application, Appl. Opt. $\underline{5}, 1959$ (Dec.).

Kovalev, A. P., and V. S. Mysorskii, Use of the Ts EP-3 color pyrometer for testing iron temperatures in the cupola spout, Liteinoe Proiz. No. 10, 17.

Krawkow, B., Spectroscopic temperature profile measurements in inhomogeneous hot gases $A D-$ 638701 (Aug.).

Kremenchugskii, L. S., et al, Large-area pyroelectric radiation receiver, Prib. i Tekchn.

Eksperim, No. 6, 169 (Nov. - Dec.).

Kroeckel, 0., A new high-temperature measuring device, Silikat Tech. 17, No. 4, 117.

Lauver, M. R., J. H. Hall, and F. E. Belles, Shocked gas temperature measurements by infrared monochromatic radiation pyrometry, NASA Lewis Research Center, Cleveland, Ohio, NASATM-X-56273; N66-18342.

Lee, R. D., NBS photoelectric pyrometer and its use in realizing the International Practical Temperature Scale above $1063^{\circ} \mathrm{C}$, Metrologia 2 , No. 4,150 (Oct.).

Lovejoy, D. R., Measure radiation above the gold point, ISA, J. 13, No. 2, 55 (Feb.).

Morris, J. C., et al, The continuum radiation of oxygen and nitrogen for use in plasma temperature determination, J. Quant. Spectroy. $\underline{6}$, No. 6,727 .

Muller, R. H., Automatic optical pyrometers measure high temperatures, Anal. Chem. 38, No. 9, 93A (Aug.).

Noquchi, T., and T. Kozuka, Temperature and emissivity measurement at $0.65 \mu$ with solar furnace, Solar Energy 10, No. 3, 125 (July Sept.).

Noon, J. H., and E. H. Holt, Radiation temperature measurements of the nitrogen after glow plasma, Rensselaer Polytechnic Inst., Troy, New York, NASA-CR-77079; N66-34074 (June). 
Oerte1, G. K., Remarks on practical spectroscopic temperature measurements in plasmas, NASA-TN-D 3737; N67-12796 (Dec.).

Penzias, G. J., S. A. Dolin, and H. A. Kruegle, Spectroradiometric pyrometry of shock-heated gases by infrared emnission and absorption measurements, App1. Opt. 5, No. 2, 225 (Feb.).

Pickett, R. L., Environmental correction for an airborne radiation thermometer, Symp. on remote sensing of environment, $4 \mathrm{th}$, Univ. of Mich., Ann Arbor, Michigan; A67-10313 (April 12-14).

Pierson, A. H., G. Zeigler, and M. Weiss, A multichannel optical pyrometer for the $1500 \mathrm{~K}$ to $3000 \mathrm{~K}$ range, Barnes Engin. Co,, Stamford, Conn., Final Rept. Contract: AF33(615)-1670; Proj: AF-8224, BEC-2016; Task: 822404; AD-480 387 (Jan.).

Reingold, L., Monochromatic optical pyrometry; experimental determination of real temperature and of the relative monochromatic emissive capacities of radiant bodies in the visible range, Rev. Gen. Thermique 5, No. 50, 109, (Feb.).

Reynolds, P. M., Measurement of aluminum extrusion temperatures, J. Inst. Metals 94, 379.

Roessler, F., Temperature measurement by the line reversal method in short term aperiodic processes, Feltman Research Labs., Picatinny Arsenal, Dover, New Jersey, Technical Translation, PATT14 ; AD-486 368L.

Sage, J. P., Measurement of high temperatures, Entropie No. 7, 19 (Jan. - Feb.).

Sasaki, Y., Some remarks on the temperature measurement of nonisothermal flames by the line reversal technique, Japan J. App1. Phys. 5, No. 5, 439 (May).

Schneider, R. T., W. N. Woerner, and H. E. Washington, A spectroscopic method of temperature measurement which does not require transition probabilities, NASA-CR-382; N68-16923 (Feb.).

Shcherbina, D. M., Measurement of the spectral emissivities of materials with a low thermal conductivity, Khar'kov State Scientific Research Inst. of Metrology, Teplofiz. Vys. Temp. 5, No. 3, 492 (May - June).

Svet, D. Ya., S. P. Naryshkin, and E. H. Khmelevskaya, Measurement of true temperatures by the method of relative spectroreflectometry, Meas. Tech. (USSR) 3, 355 (March).

Tourin, R. H., Spectroscopic gas temperature measurement, Elsevier Publishing Co., New York, N. Y.

Tourin, R. H., and G. J. Penzias, Possible techniques for optical measurements of temperature and concentration profiles in a supersonic ramjet, Sci. Tech. Aerospace Rept. 4, No. 21, 4173 Report No. NASA-CR-66112; N66-35 $\overline{9} 41$.
Watson, R., Optical temperature measurements in shock tubes from relative emission intensities Appl. Opt. $\underline{5}$, No. 2, 215 (Feb.)

Weinstein, A. S., Comparative study of radiation pyrometers for use in hot strip mills, Iron Steel Engr. 43, No. 7, 85 .

Williamson, J. A., Measurement of reme1t furnace pour temperatures by infrared pyrometry, High temperature thermometry; paper presented at a seminar at AEC Headquarters, Washington, D.C., on February 24 - 26, 1965 (Wash.-1067; TID4500) Washington: Division of Reactor Development and Technology, U. S. Atomic Energy Commission, 1966; N67-19645 (Mar.).

Zachateiskii, E. E., Use of radiation pyrometry for temperature measurements in carbon black production, Kauchuki Rezina 25, 23.

Automatic optical pyrometer, Instr. Contr. Eng. 67, (Feb.).

Infrared thermometer, Electronics 39, 46 (Apr. 18). 1967

Adcock, B. D., Temperature measurements on a subatmospheric argon plasma jet, J. Quant. Spectroye 7 , No. 3,385 .

Anisimov, B. V., and P. I. Ostashevskii, Pyrometer for measuring the temperature of carbon dioxide containing gases in a closed cell, Mekh. Avtomat. Upr. Nauch. Proiz. Sb. No. 4, 42.

Bevan, H., and R. E. Ricketts, An infrared pyromo ter for the measurement of nylon threadline temperature, J. Sći. Instr. 44, No. 12, 1048 (Dec. 12).

Bogorodskii, M. M., and E. N. Eremin, Determination of discharge plasma temperature in air under medium pressures, Zh. Fiz. Khim. 41, No. 2,470 .

Braghnichenko, G. N., Application of pyrometric light filters which meet Foot's criterion for measuring high temperature, Meas. Tech. (USSR) 12, 1471, (Dec.); Izmerit. Tekh. 12, No. 17 (Dec.).

Brown-Edwards, E. G., Temperature measurements in a hypersonic gun tunnel using a modified linereversal method, J. Fluid Mech. 27, 493 (Feb. 24).

Burk, D. L., Pyrometry, theory, laboratory, and mill, Iron Steel Engr. 44, 189 (Sept.).

Canfield, L. R., Comparison of an ionization chamber and a thermopile as absolute detectors in the extreme ultraviolet, App1. Opt. 6, 1886 (Nov.).

Dukarskii, S. M., and E. I. Trushin, Radiation pyrometer with a light guide for measuring temperatures below $1000^{\circ}$, Prib. Sist. Upr. No. 12,7 . 
English, P. E., Measurements in combustion systems, Instr. Control Systems 40, No. 8, 90 (Aug.).

Erminy, D. E., Some approximations to the Planck function in the intermediate region with applications in optical pyrometry, Appl. Opt. 6, 107 (Jan.).

Fujita, K., et al, On a colour temperature measured by two-colour pyrometer, Mem. Chubu Inst. Technol. 3,8 , (Nov.).

Gillespie, F. C., The inner eye Part 2, Thermography and ultrasonics, Instrum. Rev. 14, 105 (Mar.).

Golebrouski, K., Analysis of errors in two-colour photoelectric pyrometers, Prace Inst. Hutniczych 19, No. 1, 61.

Gray, W. T., Calibration of optical pyrometers, ISA Trans. 6, No. 3, 242 (July).

Incropera, F. P., and G. Leppert, Investigation of arc jet temperature-measurement techniques, Trans. Instrum. Soc. Am. 6, No. 1, 35 (Jan.).

Kandyba, W. W., Automation of metrological operations in the high temperature range, Pomiary Automat. Kontr. 13, 506; A68-14184 (Nov.).

Kisch, D., and M. Mahnig, Temperature measurement by means of spectral line reversal with objective methods of recording, Ber. Bunsenges. Physik. Chem. (Germany), 71, No. 1, 54.

Kunz, H., A photoelectric standard pyrometer with quasiconstant receiver sensitivity and gate weakening in the temperature range from $650^{\circ} \mathrm{C}$ to $3700^{\circ} \mathrm{C}$ Technische Hochschules, Hannover, West Germany, Ph. D. Thesis; N68-36983.

Land, T., and G. Torr, Continuous optical pyrometer based on the photovoltaic cell, GetTogether on Thermometry, Nat. Phys. Lab., New Delhi, Pap. 4.1 (13 - 17 Feb.).

Lapp, M., Effect of a continuous absorber on spectral line reversal temperature measurements, AIAA 5, 2224 (Dec.).

Lieneweg, F., and K. Menge, Measurement of the true temperature by means of radiation pyrometers and determination of the emissivity in steel melts, Arch. Eisenhuettenw. 38, No. 3, 199 (Mar.).

Mach, H., Temperature in the wake of hypervelocity projectiles determined from AIO bands, Institut Franco-Allemand de Recherches, St. Louis, France, Report No. ISL-T-36/67; N69-36313 (Oct.).

Mach, H., and H. Lehr, Temperature measurements in the wake of cylindrical projectiles capped with an alumimum layer, Institut Franco-Allemand de Recherches, St. Louis, France, Report No. ISLT-28/67; N69-36381 (July 19).

Meunier, M., Spectroscopic methods of measuring high temperatures, Entropie 49, (Jan. - Feb.).
Mysovskii, V. S., and Kovalev, Measuring temperature of molten cast iron with an optical pyrometer, Liteinoe Proizv. $2,9$.

Negrutsak, V. T., et al, Some systems of spectral ratio pyrometers, Prib. Sist. Upr. (USSR) 7 , 46.

Nesterikhin, E., and R. I. Solokhin, Methods of temperature measurement, High Speed Measurement Methods in Therodynamic and Plasma Physics; Moscow Nauka Press, 142 (1967); N68-14088.

Niedzialek, V., and J. Chamiak, A simple method for measuring surface temperature with the aid of total radiation sensors, Prace Inst. Lotnistwa 31, 24; A68-20492.

Nutter, G. D., High precision automatic optical pyrometers, Instr. Control Systems 40 , No. 5 , 96 (May).

Orning, A. A., and C. H. Schwartz, Design and construction of a thermal radiation probe, $\mathrm{J}$. Eng. Power 89, 395 (July).

Pellegrini, F., and D. Ventura, Low thermosphere temperature measurement with sodium-cloud method, Centra Nazionale de Fisica dell' Atmosfera e Metrologia, Rome, Italy; Report No. CENFAM-RDP-15; N69-19687 (May).

Platunov, Ye. S., and Yu. P. Shramko, Photographic brightness pyrometer for thermophysical measurements, Izv. Vuzov: Instr. Bldg., 9, No. 6, 138; N67-27651 (March 27).

Quin, T. J., A practical blackbody cavity for the calibration of radiation pyrometers, J. Sci. Instr. 44, No. 3, 221 (March).

Rudnaya, A. I., et al, Measuring the temperatures of the metal and gas in convertors with a photo electric pyrometer, Stal' $1,29$.

Sheheglov, D. A., Temperature determination from $x$-ray emission of the Tokamak tm-3 apparatus, JETP Lett. (USSR) 6 , 365 (Dec.).

Shelukhin, G. G., and V. 0. Yudin, Application of high-speed motion picture cameras with optical compensation for the measurement of color temperatures of self-luminous objects, High Temp. 5, No. 5, 827 (Sept. - Oct.).

St. Patraseu, I., and P. Vezeahu, Color pyrometer Metrol. Apl. (Bucharest) 14, No. 3, 125.

St. Patrascu, I., and P. Vezeanu, Color pyrometry II applications of color pyrometry, Metrol. Apl. (Bucharest) 14, No. 4, 122 .

Sugawara, M., and S. Handa, Spectroscopic determination of temperature in heavy current arc discharge, IEE Trans. Power Apparatus \& Systems 86, 1583 (Dec.).

Takata, S., et al, Calibration of a photoelectric pyrometer mounted in a solar furnace, Keiryo Kenku-sho Hakoku 16, No. 4, 206. 
Wagner, R. E., Dynamic study of temperature transducers by use of an optical method, J. Basic Eng. 89D, No. 2, 287 (June).

Young, R. S., A new infra-red radiation pyrometer, J. Sci. Instr. 44 , No. 12, 988 (Dec.) .

Zhorov, G. A., Emissivity of metals during heating in air, High. Temp. 5, No. 3, 403 (May - June).

\section{8}

Adams, J. M., The measurement of gas particle temperatures in rocket motor chambers and exhaust plumes, Pyrodynamics 61, 1; A68-27703 (June 15).

Bappu, M. K., and K. S. Ganesh, Excitation temperatures of the Walf-Rayet stars, Royal Astronomical Soc., Monthly Notices, 140, No. 1, 71; A69-26904.

Beattie, D. D., Temperature measurement of aluminum on an extrusion press using the new BACO radiation pyrometer, J. Sci. Instr. 2, No. 1, 332 (March).

Bleckrode, R., A spectroscopic method for the determination of temperatures in hot gaseous systems, Phys. Letters 27A, No. 10, 673 (Oct. 7).

Boutry, G. A., and M. Jatteau, Measurement of surface temperatures by television in the IR, Academic des Sciences (Paris), Comptes Rendus, Serie B-Sciences Physiques, 266, No. 4; A68203070 (Jan. 22).

Brooks, R. G., Using Morie interferometry in noncontact temperature measurement, Engineer, (London) 226, 398 (Sept. 13).

Butwilowicz, W., Measurements of high temperature of gases by the method of reversed spectral lines, Pomiary, Automat. Kont. 14, 539 (Dec.).

Callahan, P. S., Nondestructive temperature and radiance measurements on night flying moths, Appl. Opt. 7, 1811 (Sept.).

Dmitriev, V. D., and G. K. Khlalpau, Photoelectric pyrometer for the measurement of the actual temperature of tungsten, Zh. Prikl. Spektroskopii (USSR) 8 , No. 3, 416 (March).

English, P. E., and S. S. Hitchcock, A selfbalancing line-reversal pyrometer, British Coal Utilisation Research Association, Leatherhead Surrey, England, J. Sci. Instr. (G. B.) Series 2,1 , No. 10,984 (Oct.).

Fujita, K., T. Yamaguchi, and A. Moro-oka, On the relation between two-colour temperature and true temperature, Chubu Inst. Tech., Japan, Mem. Chubu Inst. Technol 4, 19 (Nov.).

Griffin, D. D., Infrared techniques for measuring temperature and related phenonema of microcircuits, Appl. Opt. 7, No. 8, 1749 (Sept.).
Griggs, M., Emissivities of natural surfaces in the 8 to 14-micron spectral region, General Dynamics Corp., Convair Div., Space Science Lab., San Diego, Calif., J. of Geophys. Res. 73; A69-14653 (Dec. 15).

Hacman, D., Optical measurement of substrate temperature in vacuum deposition, Optik 28, No. 2,115 .

Hovis, W. A. Jr., Infrared aircraft spectra over desert terrain, $8.5 \mathrm{u}$ to $16 \mathrm{u}$, Appl. Opt. $\underline{7}$ 1137 (June).

Idso, S. B., and R. D. Jackson, Role of sky radiance in infrared thermometry, J. Appl. Meteorology $\underline{7}, 521$ (June).

Johnston, P. D., Determination of temperature in a radio-frequency discharge using a reversal technique, Brit. J. Appl. Phys. 2, No. 1, 479 (April).

Karpenko, A. P., and A. I. Rudnaya, Radiation pyrometers with narrow spectral ranges, Kontr. Izmer. Tech. 5, 95.

Ketchum, M. D., Color ratio pyrometer system, final report, Oct. 1967 - Feb. 1968, WrightPatterson AFB, Ohio, AF Aero Propulsion Lab.; AD-677194; N69-14989 (Sept.).

Kiwaki, H., et al, A flame temperature measuring apparatus, Bull. Electrotech. Lab., Tokyo 32, No. $6,547$.

Kogan, A. V., Special features of the optical systems of visual pyrometers and the accuracy of temperature measurements, Teplofiz. Vys. Temp. (USSR) 6 , No. 3,518 .

Kortum, H., On the limits of the infrared pyrometry, Messen, Steuern, Regeln 11, No. 7, 245 (July).

Kuhn, G., and R. S. Tankin, Spectroscopic measure ments to determine temperature and carbon particle size in an absorbing propane diffusion flame, J. Quant. Spectry. Radiative Transfer (G. B.) 8 , No. 6, 1281 (June).

Lange, K. W., and H. Schenck, Measurement of the spectral emissivity of metals and metal alloys, Arch. Eisenhuttenw. 39, No. 8, 611 (Aug.).

Learner, A. C., Environmental spectroscopy, Sci. Technol. 30 (July).

Lifshits, E. V., et al, Measurement of the time behavior of temperature in a plasma-beam discharge, Opt. Spectrosc. 25, 373 (Nov.).

Lockett, R. A., Room temperature radiation thermometer, Mullard Technical Communications 10 , No. 93, 98 (May).

Lorenz, D., Temperature measurements of natural surfaces using infrared radiometers, App1. Opt. 7, No. 9, 1705 (Sept.). 
Lubleich, H., and L. Sutterlin, Temperature measurement above $800^{\circ} \mathrm{C}$ on small areas with a blue sensitive photomultiplier, Atomkernenergie 13, No. 1, 19 (Jan.).

Mach, H., On the accuracy of temperature determination from the intensity rates of AL lines, Report No. ISL-T-32/67; N69-17234.

Maier, H. F., Infrared radiometry; tool for temperature control, Chem. Eng. 75,188 (Oct. 7).

Marlatt, W. E., and R. L. Grossman, An investigation of water surface temperature by an airborne infrared radiometer, Lake Hefner, Okla. Final Report, Colorado State Univ., Fort Collins, Ca1., Contract No. DI-14-OC-D-6022; N69-25932.

Nikolaeviskii, L. S., et al, Application of the photopyrometric method for the determination of temperature fields, (Collection of Articles) J. App1. Spectroscopy 6, No. 2; AD-679370 (Jan. 17).

Noon, J. H., P. R. Blaszuk, and E. H. Holt, Electron radiation temperature measurements in a $\mathrm{CO}_{2}$ laser amplifier, Rensselaer Polytechnic Institute, Electrophysics Div., Troy, New York, J. App1. Phys. 39 5518; A69-14445 (Nov.).

Pellegrini, F., Investigation of an optical device for measuring temperature changes with height in the upper atmosphere by means of rockets or satellites, Associazione Geofisca Italiana, 16th Naples, Italy, May 22-24, Proc.; A69-18676.

Pokhil, P. F., et al, New optical method for estimating the temperature of the combusion surface of powder, Inst. Khim. Fiz. Moscow (USSR) Zh. Fiz. Khim 42, No. 9, 2350.

Probert, S. D., R. G. Brooks, and J. Maxwe11, Using Morie interferometry in non-contact temperature measurement, The Engineer 226, 398, (Sept. 13).

Riedel, J. T., High temperatures in plasma and methods for measuring them, Przegl. Elektr. 9 , 34; A68-20875 (Jan.).

Sayapina, V. I., and D. Ya. Svet, Measuring the true temperature by the intensity of the polarized radiation, Zh. Prikl. Spektroskop, (USSR) 9, No. 2, 298 (Aug.).

Schwob, J. L., Study of pulsed discharge in hydrogen using the far ultraviolet emission of an additional element: electron temperature measurement, Univ. of Paris; Ph.D. Thesis; N69-27273.

Suckewer, S., Measurement of temperature of plasma in MHD-generators and in combustion chambers by the method of recording the absolute intensities of spectral lines, Air Force Systems Command, Wright-Patterson AFB, Ohio, Foreign Technology Div., FTD-MT-24-17968; AD-685488; N69-29944 (Aug. 23).
Sugiyama, S., et al, Flame-temperature measurement by Mach-Zehnder interferometer, Kagaku Kogaku 32, No. 1, 2 .

Sukhov, F. F., and N. A. Slovokhotova, Consideration of thermal background during temperature readings with two-beam i.r. spectrometers, $\mathrm{Zh}$. Prik1. Spektroskop. (USSR) 9, No. 1, 167 (July).

Thomas, D. L., Dipped cathode arc; a simple stable radiation source for line reversal temperature measurements, J. Sci. Instr. 2, No. 1, 150 (Feb.).

Thomas, D. L., An automatic remotely operated sodium $D-1$ ine reversal temperature measuring technique, Central Electricity Generating Board, Research Labs., Leatherhead, Surrey, Eng., Combust. Flame 12, 569 (Dec.).

Thomas, D. L., Problems in applying the line reversal method of temperature measurement to flames, Central Electricity Research Lab., Leatherhead, Eng., Combust. Flame (G. B.) 12, No. 6, 541 (Dec.).

Ulmer, W., A schieren-optical technique for plasma-beam temperature measurements, Stuttgart, Techniche Universtat, Dr.-Ing. Dissertation, 63; A69-26120.

Verosh, T., et al, Diagrams for high-temperature measurements, Zh. Prik. Spectroskop (USSR) $\underline{8}$, No. 6,920 (June).

Waldemar, B., Measurement of high temperatures of gases by the method of reversed spectral lines, Pomiary, Automat. Kont. 14, 539; A69-15763 (Dec.).

Watanabe, K., and K. Kon, Radiation Pyrometer using phototransistor, Denki Seiko $\underline{39}$, No. 4 225 .

Watson, R., et al, Temperature determination from nonresolved spectra, Appl. Opt. 7,1941 (Oct.).

Wong, H. Y., and S. R. Aggarwa1, Radiometer for measuring thermal radiation intensity of one dimensional distribution, Dept. Aeronautics Fluid Mechanics, Univ. of Glasgow, Scotland, Lab. Pract. (G. B.) 17, No. 11, 1240 (Nov.).

Yoder, J. R., Temperature measurement with an infrared microscope, Appl. Opt. 7, No. 9., 1791 (Sept.).

Uncooled radiation thermometers, Instrum. Rev. 15, No. 195, 179 (March).

Photoelectronic pyrometer solves surface emissivity problem, Prod. Eng. 39, 100 (May 20).

Land/electro-nite miniature pyrometer, Ind. Heating 35 , No. 3, 562 .

Pyrometers and pyrometry, Prod. Eng. 39, 100 (May 20). 


\section{9}

Barth, C. A., et al, Ultraviolet spectroscopy, NASA, Washington, D. C. Mariner-Mars, 97; N70-18350.

Berman, L. V., et al, Low temperature detectors for long wavelength infrared spectral instruments, Instr. Exp. Tech (USSR) 6, 1630 (Nov. Dec.).

Bulewicz, E. M. et al, Temperature of metal oxide particles in flames, Combust. Flame 13, 409 (Aug.).

Chaize, J. C., Line reversal method to measure temperatures in an expansion nozzle, AixMarseilles Univ. (France) Ph.D thesis; N7026831 (Oct. 31).

Duffy, T. E., W. A. Compton, and J. V. Long, Optical pyrometer for gas turbine buckets, Solar San Diego, California, Rept. No. R69J1957-2; AD-865 938L (March).

Griffin, D. D., Infrared techniques for measuring temperature and related phenomena of microcircuits, Appl. Opt. 7, No. 9, 1749 (Sept.).

Hentschel, B. et al, Optical-electrical method of measuring high gas temperatures II., Emission method, Univ. Munster, W. Germany, Ber. Bunsenges. Physik. Chem. 73 , No. 1, 55 .

Herr, K. C., and G. C. Pinmentel, Infrared spectroscopy, NASA, Washington, D. C., In it's Mariner-Mars, 83; N70-18349.

Huster, R., D. Kisch, and M. Mahnig, Optical electrical method of measuring high gas temperature I., absorption method, Univ. Munster, W. Germany, Ber. Bunsenges. Physik. Chem. 73, No. 1,49 .

Knepper, Infrared radiometer for a Jupiter probe, Dornier-Post 1, No. 2, 52 ; A69-33425.

Kogan, A. V., Investigation of errors in a vanishing filament pyrometer, Meas. Tech. (USSR) $\underline{7}$, 947 (July).

Kogan, A. V., and M. I. Bantsur, Pyrometer for measuring temperatures below $800^{\circ} \mathrm{C}$, Poroshkovaya Metallurgiya (USSR) 6, No. 7, 102 (1966); AD-682170; N69-22537.

Kondrat'ev, K. La., Problems of infrared spectroscopy of the atmosphere connected with the solution of the problem of determining the temperature of the underlying surface by satellites, Akademiia Nauk SSSR, Izvestiia, Fizika Atmosfery i Okeana, 5, 616; A69-39114 (June).

Krakow, B., R. H. Tourin, and G. J. Penzias, Possible techniques for optical measurement of temperature and concentration profiles in a supersonic ramjet, Warner and Swasey Co., Flushing, New York, Control Instrument Division, NASA-CR-66112; N70-15082.
Kripnik, S. I., A contactless method of measuring the temperature of moving bodies having small surfaces, Air Force Systems Command, WrightPatterson AFB, Ohio, Foreign Technology Div., FTD-MT-24-443-68; AD-687018; N69-32884 (Feb.).

Kuehn, E., A color pyrometer for measuring rapidly changing surface temperatures, Ph. D. Thesis, Technische Hochschule, Hanover, West Germany; N69-28501.

Levitin, I. B., and A. I. Kontsevich, The accuracy of radiation pyrometers, Inzh.-Fiz. Zh. 16, 717 .

McRea, T. G., Spectroscopic temperature measurements of shock-heated helium, AIAA J. 7, 350 (Feb.).

Mossey, P. W., Experimental pyrometers for turbine blade temperature measurement, SAE, National Air Transportation Meeting, New York, N. Y., Paper No. 690431; A69-41649 (Apr. 21 24).

Nash, D. B., Proton bombardment-induced target temperatures and thermal accommodation coefficients of rock powders: measurements by infrared pyrometry, Jet Propulsion Lab., California, Inst. of Tech., Pasedena, Contract NAS7-100; NASA-CR-100922; JPL-TM-33-413; N69-25406 (Feb. 15).

Neugebauer, G., et al, Infrared radiometry, NASA Washington, D. C., Mariner-Mars, 105; N70-18351.

Pollack, F. G., and R. O. Hickle, Surface temperature mapping with infrared photographic pyrometry for turbine cooling investigations, NASA Lewis Research Center, Cleveland, Ohio, NASATN-D-5179; N69-23895 (May).

Popov, E. G., and M. A. Tsikulin, Spectral brightness of shock waves in air, Zh. Eks. Teor. Fiz. 56, 522; A69-25755 (Feb.).

Pratt, N. H., and A. P. Blow, A theoretical study of the interpretation of emission-absorption intensity ratio: temperature measurements in the absence of thermal equilibrium, J. of Quant. Specty. Radiative Transfer 9, 423; A69-22255 (March).

Queffelec, J., Photoelectric spectroscopic study, in the visible range, of the radial temperature distribution of an argon-hydrogen plasma, Academic des Sciences (Paris) Comptes Rendus, Serie B-Sciences Physiques, 268, No. 5, 386; A69-20758 (Feb. 3).

Quinn, T. I., and M. C. Ford, On the use of the N. P.L. photoelectric pyrometer to establish the temperature scale above the gold point $\left(1063^{\circ} \mathrm{C}\right)$, Nat. Physical Lab., Teddington, Eng., Proc. Roy. Soc. (London) 312, No. 1508, 31 .

Rao, P. K., W. R. Curtis, and E. P. McLain, Remote sensing of sea surface temperature, Space Technology, and Society; Canaveral Council of Technical Societies, Space Congress, 6th, Coca Beach, Fla., Proceedings; A69-35057 (Mar. 17). 

Rixom, P. J., and W. G. Townsend, The silicon intergrating light detector applied to optical pyrometry, Div. Electrical Engineering, Univ. Coll. Swansea, Wales, J. Sci. Instr. (G. B.) Series 2, 2, No. 2, 153 (Feb.).
Seleznev, V. A., et al, An optical method of measuring the burning-surface temperature of condensed systems, Combust. Flame, 13, 139; A69-28453 (Apr.).

Simmons, F. S., H. Y. Yamada, and C. B. Arnold, Measurement of temperature profiles in hot gases by emission-absorption spectroscopy, Final Report, Michigan Univ., Ann Arbor, NASA-CR$72491 ; \mathrm{N} 69-32557$.

Smith, D. S., and E. S. Starkman, Spectroscopic method for simultaneous determination of species concentration and temperature in a cyclic combustion process, Rev. Sci. Instr. 40 , No. 12,1541 (Dec.).

Sparrow, E. M., and T. M. Kuzay, Radiation incident on a temperature sensor in a tube having non-isothermal walls, J. Heat Transfer 91, 285, (May).

Thomas, D. L., An automatic remotely operated sodium $D$-line reversal temperature measuring technique, Central Electricity Research Lab., Leatherhead, Eng., Combust. Flame (G. B.) 12, No. 6, 596 (Dec.).

Tveekrem, J. 0., Pyrometry error on high-temperature graphite from soot formation, Brookhaven Nat. Lab., Upton, New York, J. Chem. Phys. 49, No. 6, 2878 (Sept. 15).

Unger, H. J., F. K. Hill, and N. G. Paul, Spectroscopic determination of high velocity flow field static temperatures, International Congress on Instrumentation in Aerospace Simulation Facilities, 3rd, Poly. Inst. of Brooklyn, Farmingdale, New York; A69-35752 (May 5 - 8).

Wank, M. R., Application printers for infrared thermometry, Instrum. Techno1. 16, 43 (Jan.).

Optical pyrometer for gas turbine buckets, Solar, San Diego, California, Report No. R69J-1957-5; AD-865932L (June) .

Optical pyrometer for gas turbine buckets, Solar, San Diego, California, Report No. R69J-1957-3; AD-865939L (April).

Optical pyrometer for gas turbine buckets, Solar, San Diego, California, Report No. R69J-1957-4; AD-865940L (May).

Optical pyrometers for gas turbine buckets, Solar, San Diego, California; AD-868504L (Nov.).

Optical pyrometer for gas turbine buckets, Solar, San Diego, California, Report No. RDR-1647; AD-868553L (July). 


\section{Expansion Devices}

1965

Koseki, T., Comparative tests on the performance of metal thermometers, Japanese and non-Japanese, Volt, 12 (Dec.).

\section{6}

Callahan, J. T., Evaluation of Weksler Instruments Corp. gas actuated thermometers, Naval Ship Engineering Center, Philadelphia, Pa., Final Evaluation Report, Proj: NAVSECPHILADIV-A-644, SF-013-06-2; Task: 3950; AD-487 905L (Aug.).

Erdmann, J. C., and J. A. Jahoda, Inert thermometer, J. App1. Phys. 37, 3869 (Sept.).

Erdmann, J. C., and J. A. Jahoda, Transient thermometry with inert thermometers, Boeing Scientific Research Labs., Seattle, Washington, Report No. D1-82-0537; N66-38127 (May).

Glew, D. N., et al, Thermometer for proton magnetic resonance studies of aqueous solutions, Ana1. Chem. 38, No. 13.

Gregory, C., and K. B. Krueger, Evaluation of Weksler, small bulb, mercury actuated thermometer, Naval Boiler and Turbine Lab., Philadelphia, Pa. Final Report No. NBTL-A-578; Proj: SF-013-06-20; Task: 3950; AD-477 083L (Jan.).

Krueger, K. B., Investigation of factors affecting $3 / 8$ inch thermometer bulb accuracy, Naval Boiler and Turbine Lab., Philadelphia, Pa., Report No. NBTL-A-708; AD-485 261L (June 20).

Thyer, L., Use of a mercury-in-glass thermometer as a dew point hygrometer, J. Sci. Instr. 43, No. 1,43 .

Van Dijk, H., On the use of the vapour pressuretemperature radiation in thermometry, Physica 32, No: 5, 945 (May).

\section{7}

Bailey, R. G., et al, A study of all-fluid, hightemperature-sensing probes, NASA-CR-90092: Honeywe11-12023-FR1; CFSTI; N68-10286 (Apri1).

Bansal, T. D., Equipment for large scale testing of clinical thermometers, Get-Together on Thermometry, Nat. Phys. Lab., New Delhi, Pap. 3.3 $(13-17$ Feb.).

Bansa1, T. D., et al, The reading of liquid-inglass thermometer's, Get-Together on Thermometry, Nat. Phys. Lab., New Delhi, Pap. 2.3 (13 - 17 Feb.).

Bansal, T. D., and M. M. Shasma, Liquids for thermometer comparators, Get-Together on Thermometry, Nat. Phys. Lab., New Delhi, Pap. 2.4 (13 - 17 Feb.).

Bansal, T. D., et al, Equipment and methods of NPL, Delhi, for calibrating liquid-in-glass thermometers, Get-Together on Thermometry, Nat. Phys. Lab., New Delhi, Pap. 2.5 (13-17 Feb.).

Bansal, T. D., Liquid-in-glass thermometers for Indian conditions, Get-Together on Thermometry, Nat. Phys. Lab., New Delhi, Pap. 2:1 (13 - 15 Feb.).

Callahan, J. T., Evaluation of American Standards gas actuated thermometers, Naval Ship Engineering Center, Phila. Div., Philadelphia, Pa., Report No. NAVSECPHILADIV-A-752; Proj: SF-01306-20; Task: 3950; AD-805 399L (Jan.).

Gukov, G., Diamond ampoules for temperature measurement, Ind. Diamond Rev. 27, No. 318, 207 (May).

Miftakhan, E. Z., B. A. Famin, and N. P. Karaleva, High temperature manometer-type thermometer, Prib. Sist. Upr. No. 8, 13.

Moser, H., J. Otto, and W. Thomas, Gas thermometer measurements at high temperatures, IV Determination of thermodynamic temperatures of fixed points between $232^{\circ}$ and $661^{\circ} \mathrm{C}, \mathrm{Z}$. Physik. 206, No. 2, 223.

Parkinson, R. C., An introduction to the design and operation of cryogenic vapour-pressure thermometers, Rocket Propulsion Establishment, Westcott, England, Report No. REP-TM-437; $A D-826520$ (Apr.).

Rossler, T., Temperature measurements; A68-14621.

Thompson, R. D., Liquid-in-glass thermometers, principals and practices, Proc. Instrum. Soc. Am. 22nd, Arn. Conf. 22, No. 1, Paper No. M9-1MEST IND-67.

1968

Dittrick, R. T., Probe averages temperature profiles, Instrum. Technol. 15, No. 5, 60 (May). $\because$

Galatchi, Gh., and V1. Farsirotu, Oxygen condensation thermometer for measuring temperatures from 77 to $91^{\circ} \mathrm{K}$, Rev. Chim. (Bucharest) 19, No. 7,424 .

Hey, E. N., Sma11 globe thermometers, J. Sci. Instr. $\underline{2}$, No. 1, 955 (Sept.).

Preston-Thomas, H., and C. G. Kirby, Gas thermometer determinations of the thermodynamic temperature scale in the range $-183^{\circ} \mathrm{C}$ to $100^{\circ} \mathrm{C}$, Div. Applied Physics, National Research Council, Ottawa, Ontario, Metrologia (Germany) 4, No. 1 , 30 (Jan.).

Thompson, R. D., Liquid-in-glass thermometersprinciples and practices, ISA Trans. $\underline{7}$, No. 2, 87.

Ween, S., Care and use of liquid-in-glass 1aboratory thermometers, ISA Trans. 7 , No. 2, 93. 
1969

Cazan-Corbasca, V., and C. Spurcaciu, Manufacture of glass liquid thermometers for high temperatures, Ind. Usoara (Bucharest) 15, No. 9, 568.

McConville, G. T., Thermomolecular pressure corrections in helium vapor pressure thermometry; the effect of the tube surface, Cryogenics 9, 122 (April).

\section{Aspirated Devices}

1965

Barber, R., Venturi pneumatic pyrometer for temperature measurement, Ind. Process Heat $\underline{5}, 4$ (Dec.).

1966

Vtnogradov, B. S., and M. D. Yermolayev, Tests with stagnation-temperature sensors having an internal channel by the equivalent pressure-drop method, NASA-TT-F-10041, Aviatsionnaya

Tekhnik (USSR) 3; N66-23542 (Apri1).

\section{7}

Dalle, D. M., and F. H. Bowditch, Nozzle thermocouple for measurements in high-temperature gases, Int. J. Heat Mass Transfer 10, 477 (Apri1).

Fischer, S., Thermodynamic temperature measuring device for the measurement of high gas temperatures, Wiss. Z. 16, No. 2, 309.

Husted, F., Development of measuring technique for the accurate indication of turbine inlet temperature, Instr. Soc. of Am. J. National; 13 th. Aero-Space Instrumentation Symposium, San Diego, California, Proceedings, A68-42733 (June 13 - 15).

\section{8}

Levinson, H., Vacuum thermocouples-versatile components for ac measurements, Best Electrics Div., Harry Levinson Co., Seattle, Washington, 27, No. 6, 62 (June).

\section{9}

Hills, A. W., and A. Paulin, the construction and calibration of an inexpensive microsuction pyrometer, J. Sci. Instrum. (J. Physics E) Series 2, 2, 713 (August).

\section{Other Methods, Descriptive Articles}

\section{4}

Grey, J., Thermodynamic methods of high-temperature measurement, Princeton Univ. New Jersey, Interim Tech. Rept. ARL 64 179; AD-609977 (Oct.).

Minzner, R. A., B..0. Sauermann, and L. R. Peterson, Temperature determination of planetary atmospheres, NASA-CR-71862; GCA-TR-64-9-N; N6623682 (June).

Pytlinski, J., Measurements of the temperature of high speed flames by variable-temperature spectrophotometric methods, Pomiary, Automat. Kontrola 10 , No. 2, 49 (Feb.).

Subramanian, D. V., An electronic thermometer for remote-indicating applications, Indian J. Meteorol. 15 , No. 4,645 .

\section{5}

Baker, T. W., et a1, Temperature measurement in a high-temperature $x$-ray diffractometer, Atomic Energy Research Establishment, Harwe11, Eng., AERE-R-4556; NSA20-7337.

Carnevale, E. H., et al, U1trasonic temperature measuring device, Quarterly progress report No. 1, Parametrics, Inc., Waltham, Mass., NASA-CR54780; NSA20-7341 (Oct.).

Cataland, G., and H. Plumb, Isotherms determined by the National Bureau of Standards acoustical thermometer in the liquid helium temperature range, J. Res. Nat. Bur. Stand. 69A, No. 6, 531 (Nov. - Dec.).

Chistyakov, V. S., Methods of measuring rapidly varying temperatures of gas streams, High Temp. 3, No. 6,832 (Nov.).

Dubrovskaya, 0. N., et al, Determination of temper ature by hydrogen spectrum, Akad. Nauk Belerussk. SSR, Prik1. Spektroskoppi 2, No. 5, 470 .

Duerst, R., and A. Merbach, Accurate N.M.R. (nuclear magnetic resonance) temperature measurements, Rev. Sci. Instr. 36, No. 12, 1896.

Froehlich, C., Method for the exact measurement of local temperature, Helvetica Physica Acta. 38, No. 7,637 .

Hutchinson, H. D., Study of heat sensitive radioisotopes for temperature measurement application, Meteorology Research, Inc., Altadena, Calif., NASA-CR-65264; N66-21002 (July).

Inglis, M. E., and L. Airey, Fluid oscillator as a temperature sensor, Sci. Tech. Aerospace Rept. 3, No. 24, 4143; N65-36403.

K1ipping, G., and F. Schmidt, Temperature measurement with the vapor-pressure thermometer, Kaltetechnik 17, No. 12, 382 (Dec.). 
Kolodziejski, J., and E. Nowakowski, Temperature measurement with the aid of semiconductor diodes and transistors, Pomiary, Automat. Kaut 11,522 (Dec.).

Kutovoi, V. I., and V. I. Stetsenko, Checking the temperat're of liquid metals by means of the radioisotope method, Meas. Tech. (USSR) 8, 720 (Aug.)

Lenoir, W. B., Remote sounding of the atmospheric temperature by microwave measurements, Symospium on Electromagnetic Sensing of the Earth from Satellites, Univ. of Florida, Coral Gables, Fla., Proceedings; A67-40350 (Nov. 22 - 24).

Milchailov, M. D., Measuring the temperature of flows with a pulsating velocity, Meas. Tech. (USSR) 5, 419 (Nov.).

Noel, Y., et al, Acoustical method for the measurement of temperature, Centre Nat. Rech. Met. Brussels No. 5, 53 (Dec.).

Osinskii, V. I., and N. N. Sirota, Measurement of low temperatures by the volt-ampere and recombination characteristics of gallium arsenide diodes, Vestsi Akad. Navuk Belarusk. SSR, Ser. Fiz.-Mat. Navuk No. 3, 130

Plumb, H. H., and G. Cataland, Acoustical thermometer, Science 150, 155, (Oct. 8).

Schueller, K. H., Use of Seger cones for assessing the degree of firing, Ber. Deut. Keram. Ges. 42, No. 9,336 .

Singleton, H., Novel principle for the measurement of low temperature, Advan. Cryog. Eng. 10 (A-L). 239 .

Sterbrutzel, G. A., A probe for the measurement of high surface temperatures, U.S. Government Report AFFDL TR-65-121; AD-624 888 (Sept.).

Vanier, J., Nuclear quadrupole resonance (N.Q.R,) thermometry, Metrologia 1, No. 4, 135.

Weinstein, I., and R. R. Howell, Technique for measuring high-temperature isotherm patterns on aerodynamically heated models with experimental results, NASA, Langley Station, Va., NASA-TN-D2769 ; N65-23162.

\section{6}

Abramovich, B. G., Measurement of surface temperature by means of thermoindicators, Teplofiz. Vys. Temp. 5, No. 3, 535 (May - June).

Belcher, P. R., and R. W. Wilson, Templugs, Engineer (London) 221, 305 (Feb. 25).

Bogdan, L., and K. C. Hendershot, Density and temperature measurement in the base of a clustered rocket model using an electron beam technique, Proc. Int. Congress on Instrumentation in Aerospace Simulation Facilities 2nd, Stanford Univ., Stanford, Calif. (Aug. 29 - 31).
Bowman, B., and D. Whittaker, The measurement of high gas temperatures using colliding shock waves, Brit. J. Appl. 17, No. 2, 219 (Feb.).

Carnevale, E. H., L. C. Lynnworth, and S. L. Klaidman, Ultrasonic temperature measuring device, Second Quarterly Progress Rept., Parametrics, Inc., Waltham, Mass., NASA-CR-54896 N66-16919.

Carnevale, E. H., et al, Ultrasonic temperature measuring device, Third Quarterly Progress Rept Parametrics Inc., Waltham, Mass., NASA-CR-54964; NSA 20-29486; N66-27742 (Apr.).

Carnevale, E. H., et al, Ultrasonic temperature measuring device, Fourth Quarterly Rept., Parametrics, Inc., Waltham, Mass., NASA-CR-72037; N66-34936 (July).

Chester, M., High-frequency thermometry, Physical Review 145, No. 1, 76 (May).

Crovini, L., Methods for the measurement of absolute temperatures around the gold solidifici tion point by comparison of thermal noise voltage of resistors, Termotecnica 20 , No. 1,17 .

Cunningham, J. W., et al, Measurement of local density and temperature in wind tunnels using electron beams, Int. Congress on Instrumentatio in Aerospace Simulation Facilities, 2nd Proc., Stanford Univ., Stanford, Calif., (Aug. 29 - 31

Datar, S. V., and P. M. Pakkir Mohammed, A record ing telethermometer for use at airports, Indian J. Meteorol. Geophy. 17, 633 (Oct.).

Didion, D. A., and Y. H. Oh, A quantitative schlieren-grid method for temperature measurema in a free convection field, Catholic Univ. of America, Washington, D. C., Dept. of Mech. Eng. Report No. TR-1; AD-637 012; N66-38522 (July 15

Dmitrenko, I. M., et al, Thermometric characteristics of semiconductor diodes, Cryogenics 6 , 357 (Dec.).

Hammond, L., and A. Benjaminson, A quartz linear thermometer, Mes. Regul. Automat. 31, No. 2, 73 (Feb.).

Hunter, W. W. Jr., Rotational temperature measurements; $300^{\circ} \mathrm{K}$ to $1000^{\circ} \mathrm{K}$ with electron beam probe, Proc. 21st Instrum. Soc. Am. Conf.; N6827416 .

Hutchinson, H. D., Study of heat sensitive isotopes for temperature measurement application, Final Report, Meteorology Research Inc., Altadena, Calif., MR165-FR-285; NASA-CR-65264; N66-21002.

Klyuchnikov, A. D., A method for determining the true gas flow temperature from the readings of two thermocouples, Thermal Eng. 13, 111 (Dec.).

Larson, G. S., et al, Upper atmospheric sonic thermometry, ISA Trans. 5, No. 3, 233 (July). 
Llinas, J., and W. C. Rustay, Temperature and density measurements in the base region of a clustered rocket model using an electron beam technique, NASA-CR-77126; CALHM-2107-Y-2; N66-34045 (July).

Lynnworth, L. C., and E. H. Carnevale, Techniques for mounting an ultrasonic temperature device, Final Report, Parametrics, Inc., Waltham, Mass., NASA-CR-54979; N66-35940 (Feb.).

Lynnworth; L. C., and E. H. Carnevale, Ultrasonic temperature measuring device, Fifth Quarterly Progress Report, Parametrics, Inc., Waltham, Mass., NASA-CR-92101; N66-39986 (Oct.).

Marrone, P. V., Rotational temperature and density measurements in underexpanded jets and shock waves using an electron beam probe, Toronto Univ. 0ntario, UTIAS-113; AD-482794; N66-36087 (Apr.).

Mitsuta, Y., Sonic anemometer-thermometer for general use, Meteorol. Soc. 44, 12 (Feb.).

Moir, L. E., Measurement of stagnation point temperature with high $g$ telemetry, Int. Congress on Instrumentation in Aerospace Simulation Facilities 2nd Proc., Stanford Univ., Stanford, California (Aug. $29-31$ ).

Parkhomenko, V. D., et al, Temperature measurement by a strain-gage method, Ind. Lab. (USSR) 32, No. 7, 1095 (July).

Quigg, R. K., Precision electronic thermometer for colorimetry, Electron. Eng. 38, No. 456, 92 (Feb.).

Shore, F. J., and R. S. Williamson, Suggested thermometer for low temperatures using Nyquist noise and correlator-amplifier, Rev. Sci. Instr. 37, No. 6, 787 (June).

Szecsi, L., Spherical transmitter for temperature measurement, Int. Elektron. Rundsch. 20, 33 (Jan.).

Takami, K., and K. Matsuura, Capacitance thermometer for rotor, Rev. Sci. Instr. 37, No. 11, 1505 (Nov.).

Von Engel, A., Investigation of the properties of hot plasma gases and measurement of gas temperatures near solid surfaces, Oxford Univ. (England) AFML-TR-65-419; AD-625043; N66-18536.

White, J. P., Temperature measurements of rotors having high voltage excitation, Instr. Control Systems 39, No. 5, 113 (May).

Wilner, B., On a spectroscopic method for measuring the electron temperature of a plasma, Royal Swedish Acad. of Eng. Sci., 46, PH-41; N67-30040.

Wisnieff, S. F., and H. Bardach, Radioactive krypton simplifies temperature mapping of turbine blades, SAE J. 74, 56 (Aug.).

Yasuhara, M., Rotational temperature measurement of the flow expanding from a low-density sonic orifice, Univ. of Southern California, Los Angeles,
Dept. Aerospace Engineering, Rept. No. USCAE-103; AD-648879 (Aug.).

Zhuber-Okrog, G., The measurement of rapidly changing gas temperatures by means of ultrasonics, Osterr. Ing. - Z.9, 124.

Zoerb, E. G., All-fluid temperature sensing, Proc. Texas A. M., Ann. Symp. Instr. Process Ind. 21, 32 .

Low temperature scale, Instr. Control Systems 39 , 94 (Jan.).

\section{7}

Agrawa1, P. L., et al, Molten steel temperature measurement of Rourkela Steel Plant, Get-Together on Thermometry, Nat. Phys. 'Lab., New Delhi, Pap. 5.8 (13 - 17 Feb.).

Aro, T. O., and D. Walsh, Attemped microwave measurement of temperature of a shock-heated plasma, Phys. Fluids 10, 1468 (July).

Benjaminson, A., Precision measurement of ocean temperatures, Hewlett-Packard J. 18, No. 812 , (Apr.).

Carnevale, E. H., et al, Simultaneous ultrasonic and line reversal temperature determination in a shock tube, Phys. Fluids 10, 1459 (July).

Cunningham, J. W., et al, Density and temperature in wind tunnels using electron beams, Trans. IEEE AES-3, No. 2, 269 (May).

D'iachkov, B. G., Measurement of flame temperature by the method of alpha-particle deceleration, Teplofiz. Vys. Temp. $\underline{5}, 1071$; A68-18448 (Nov. Dec.).

Edney, B. E., Temperature measurement in a hypersonic gun tunnel using heat-transfer methods, J. Fluid Mech. 27, 503 (Feb. 24).

Gaylord, W., Miniaturization of the fluidic temperature sensor, Harry Diamond Labs., Washington D. C., Report No. HDL-TR-1344; AD 380-928L (Feb.).

Halbach, C. R., B. A. Otsap, and R. A. Thomas, Fluidic (pure fluid) temperature sensor, phase 1 , Marquardt Corp., Van Nuys, Calif., Astro Div.; Final Technical Report No. 25212; SAN-639-7; CFSTI; N68-24713 (Jan.).

Halbach, C. R., B. A. Otsap, and R. A. Thomas, A pressure insensitive fluidic temperature sensor, Advances in Fluidics, Fluidics Symposium, Chicago, I11.; A67-28322 (May 9 - 11).

Kamper, R. A., Millidegree noise thermometry, Virginia Univ. Phys. of Superconducting Devices, CFSTI; N69-37189.

Kelley, L. R., A fluidic temperature control using frequency modulation and phase discrimination, J. Basic Eng. 89, No. 2, 341 . 


\section{Other Methods, Descriptive Articles}

Kozhin, V. M., Halite thermometer for x-ray study of materials from 77 to $1037^{\circ} \mathrm{K}$, Prib. Tekh. Eks. (USSR) No. 1,185 (Jan.).

Lynnworth, L. C., et al, Hot gas measurements with ultrasonics, Space/Aeronautics 48, 121; A68-147 62 (Sept.).

Lynnworth, L. C., and E. H. Carnevale, Ultrasonic temperature measuring device, Panametrics, Inc., Waltham, Mass. NASA-CR-72339; N68-16506 (Aug.).

Lynnworth, L. C., and E. H. Carnevale, Ultrasonic temperature measuring device, Quarterly progress report, Panametrics, Inc., Waltham, Mass., NASACR-72157; QPR-6; N67-19914.

McDonough, M. S., L. C. Lynnworth, and E. H. Carnevale, Ultrasonic measurement of core material temperature, Phase I, Panametrics Inc., Waltham, Mass., NASA-CR-72395; N68-24327 (Dec.).

Mrgudick, J. N., Batteries as temperature and pressure sensing devices, U. S. Army, Electronic Command, Ann. Power Sources Conf., 2lst, Atlantic City, New Jersey, A68-17830 (May 16 - 18).

Mustafin, K. S., V. A. Seleznev, and E. I. Shtyrokov, The use of holography to study the temperature distribution field of a flame, Opt. i Specktroskopiya (USSR) 22, No. 2, 319 (Feb.).

Niwa, N., et al, Virtual air temperature measurement by means of ultrasonic resonance, J. Soc. Instrum. Cont. Eng. 6, No. 7, 463 (July).

Osborne, R. L., and D. D. Cooksey, Studies of a fluidic oscillator as a temperature sensor, Lawrence Radiation Lab., Livermore, Calif., UCRL50344; N68-25691 (Nov. 1).

Parker, R., Measuring transient surface temperatures with coatings of temperature indicating materials, Proc. 22nd, Instr. Soc. Am. Ann. Conf., 22, No. 2, Paper No. P12-4-PHYMID-67; N $67-392 \overline{45}$.

Pashkovskiy, B. A., and M. B. Fridzon, Device for measuring temperature, Air Force Systems Command Wright-Patterson AFB, Ohio, FTD-TT-65-1938; AD-638880; N67-11148.

Radovskii, I. S., Acoustic method of determining the critical temperature of a substance, High Temp. (USSR) 5, No. 6, 953 (Nov. - Dec.).

Rao, S. R., Temperature indicating materials, GetTogether on Thermometry, Nat. Phys. Lab., New Delhi, Pap. 4.4 (13 - 17 Feb.).

Schadowski, S. S., Temperature performance measurement methods for temperature-compensated quartz oscillators, Army Electronics Labs., Fort Monmouth, New Jersey, Rept. No. ECOM-2896; AD664 157; N68-18333; (Oct.).

Shramko, Yu. P., Photographic pyrometry, Leningrad Inst. of Precision Mechanics and Optics, High Temp 5, No. 2 (Mar. - Apr.), Translated from Teplofiz Vys. Temp. 5, No. 2, 367 (Mar. - Apr.).
Soviani, R., and I. Asavinei, New method for high= temperature measurement in liquid media, Special immersion thermocouple Metrol. Apl. 14, No. 1, 24.

Sun, K. H., et al, Attempt to measure the temperature of a laser-produced plasma using neutrondetection technique, J. Appl. Phys. 38, 3402 (July).

Willens, R. H., E. Buehler, and E. A. Neshitt, Inductance thermometer, Rev. Sci. Instr. 39, No. 2 (Feb.).

Yamaga, J., and S. Shibata, Gas temperature measurement using ultrasonic waves, Bull. JSME (Japan Soc. Mech. Engrs.) 10, No. 37, 149 (Feb.).

Instant temperature measurement, Engineering, (London) 203, 429 (Mar. 17).

Low-temperature measurements using nuclear quadrupole resonance, Engineering (London) 204, 548 (Oct. 6).

\section{8}

Abel, W. R., and J. C. Wheatley, Magnetic thermometry with cerium magnesium nitrate and its relation to the properties of ${ }^{3} \mathrm{He}$., Dept. of Physics, Univ. of Cal., San Diego, Phys. Rev. 21, No. 9, 597 (Aug. 26).

Alinovskii, N. I., et al, Measurement of the electron temperature of a plasma using a differential analyzer of charged particles according to energy, Trans. from Russian Preprint No. 260; Available: AEC Depository Libraries; N70-28557.

Bauder, U., H. P. Popp, Measurement of highest temperatures, VDI Z. 110, No. 28, 1227 (Oct.).

Bell, J. W., Solid acoustic thermometer, Ultrasonics 6,11 (Jan.).

Blum, S. E., and R. J. Chicatka, Sapphire rod thermosensor, Rev. Sci. Instr. 39, No. 2, 277 (Feb.).

Bogue, R. K., and L. D. Webb, Advanced air data sensing techniques, NASA-Flight Research Center Edwards, Calif., NASA-TM-X-61115; N68-25328 (March).

Bovsheverov, V. M., and M. I. Mordukhovich, An acoustic thermometer-interferometer for measuring temperatures in the stratosphere, Akademiia Nauk SSSR, Izvestiia, Fizika Atmosfery i Okeana, 4, 1019; A69-28777 (Oct.).

Boylan, D. E., Measurements of local heat-transfer rate as a cooled sharp flat plate in the merged layer flow regime, final report, Arnold Engineering Development Center, Arnold AFB, Tenn., AEDCTR-69-71; AD-689177; N69-37626 (June).

Bryant, R. W., and W. A. Dukes, Measurement of embrittlement temperatures (brittle points) of composite propellants by the bending beam method; AD-686398; N69-31480. 
Czysz, P., and W. P. Dixon, Thermographic heat transfer measurement, Instr. Control Systems 41, No. 10, 71; A69-10152 (Oct.).

Freyheit, P. J., et al, Ultra-high temperature measuring techniques, Final Report, Sperry Rand Research Center, Sudbury, Mass., NASA-CR-86055; N68-24571 (May).

Galatchi, Gh., Oxygen condensation thermometer for measuring temperatures from 77 to $91^{\circ} \mathrm{K}$, Rev. Chim. (Bucharest) 19, No. 7, 424 .

Hariharan, R., and M. Lakshminarasiah, Temperature measurement by sound velocity method, J. Inst. of Eng. (India) Mech. Eng. Div., 48, 593; A6840052 (May).

Hoppe, J. C., Rotational and vibrational temperature measurement in the 12-inch hypersonic ceramic-heated tunnel, NASA-Langley Research Center, Langley Station, Va., NASA-TN-D-4892; N69-10932 (Nov.).

Hunter, W. W. Jr., Investigation of temperature measurements in $300^{\circ} \mathrm{K}$ to $1100^{\circ} \mathrm{K}$ low-density air using an electron beam probe, NASA, Langley Research Center, Langley Station, Va., NASA-TN-D4500; N68-24244.

Il'ina, V. A., and V. K. Kritskaya, X-ray diffraction determination of the characteristic Debye temperature of some metals, Sb. Tr. Tsent. Nauch.-Issled. Inst. Chern. Met. No. 59, 129.

Jarratt, T. J., Infrared microscope for temperature measurement of small areas, Mullard Technical Communications 10, No. 93, 101 (May).

Johnson, J. L., High gas temperatures:-measured by fluidic sensors, Space/Aeronautics 50, 78 (Aug.).

Johnston, P. D., Determination of temperature in a radio-frequency discharge using a reversal technique, London, Univ., Imperial Coll. of Science and Technology, Dept. of Physics, Eng., Brit. J. Appl. Phys. 1, 479 (Apr.).

Kantor, S. A., et al, The measurement of the initial gas temperature in GT (gas turbine) based on indirect parameters, Air Force Systems Command, Wright-Patterson AFB, Ohio, Foreign Technology Div. FTD-HT-23-718-68; AD-686236; N69-31181 (Feb. 26) .

Kerenyi, I., and I. Vacz, Electronical (initial current) measurement of the cathode temperature Acta Technic. 62, No. 3-4, 285; A68-44599.

Lakshminarasiah, M., and R. Hariharan, Temperature measurement by sound velocity method, $\mathrm{J}$. Inst. Eng. (India) 48, No. ME 5, 593 (May).

Lindsay, W. T. Jr., and R. J. Ruka, Electrochemical thermometry: a new approach to the determination of elevated temperatures on the thermodynamic scale, Westinghouse Res. Lab., Pittsburgh, Pa., Electrochim. Acta 13, No. 8, 1867.
Makhankov, V. I., I. S. Sidorenko, and G. F. Shemonaev, Capactive sensor for measuring ultralow temperatures, Instr. Exp. Tech. (USSR) No. 4, 986 (July/Aug.).

McDonough, M. S., L. C. Lynnworth, and E. H. Carnevale, Ultrasonic measurement of core material temperature, Phase II, Parametrics, Inc., Wal tham, Mass. NASA-CR-7246; N69-12302 (Aug.).

Meier, R., Method and apparatus for measuring high temperatures, British Patent No. 1,124,136 (Aug.).

Rassudova, N. S., and N. N. Khlestova, Use of urotropine complexes as temperature indicators, Lakokrasochnye Materialy i ikh Primenenie No. $4,49$.

Ringwall, C. G., and L. R. Kelley, Fluidic technique for-measuring the average temperature in a gas turbine exhaust duct, J. Eng. Power 90, 265 (July).

Sa, A. De., A radio-frequency method for determining Curie point temperatures, School of Physics, Univ. of Newcastle upon Tyne, J. Sci. Instr. Series 2, 1, 1136 (July 12).

Sprott, J. C., Admittance probe method of measuring time resolved plasma electron temperature, Rev. Sci. Instr. 39, No. 10, 1569 (Oct.).

Svet, D. Ya., New methods and systems for the measurement of actual temperatures with realistic thermal radiation characteristics, Techtron Corp. Glen Burnie, Md., NASA-TT-F-11932; N6837611 (Oct.).

Tippetts, T. B., Optical study of a fluidic temperature sensor, Rept. No. D6-58378; CFSTI; AD-675770; N69-12235.

Torkelson, T. J., and J. N. Wilson, A fluid temperature sensor; A69-12089 (Nov. 4).

Weir, J. A., Paint, temperature indicating Petro/ Chem. Eng. 40, No. 21 (Aug.).

Williams, R. H., E. Buehler, and E. A. Nesbitt, Inductance thermometer, Rev. Sci. Instr. 39, No. 2, 194 (Feb.).

Inorganic salt as cryogenic thermometer, Engineering (London) 205, 78 (Jan. 12).

\section{9}

Adler, A. J., Wireless temperature measurement with radio telemetry, Temperature Measurements Society, Conf. and Exhibit, 6th, Hawthorne, California, Proceedings; A69-30156 (Apr. 21 - 22).

Airey, L., Fluidic sensors for jet engine control, American Institute of Aeronautics and Astronautics, Propulsion Joint Specialist Conf., 5th, USAF Academy, Colorado, Paper No. 69-542; A6932699 (June 9 - 13). 
Bentz, C. E., W. F. Platz, and J. J. Batka, Development of a turbine inlet temperature sensor, American Institute of Aeronautics and Astronautics, Propulsion Joint Specialist Conf. 5th, USAF Academy, Colorado Springs, Colo., Paper No. 69-544; A69-32692 (June 9 - 13)

Bergstrom, L., Nondestructive testing by highspeed thermography, American Society for Nondestructive Testing, Conf. 28th, Detroit, Mich., Materials Evaluation 27, No. 25A; A69-30316 (Oct. 14 - 17).

Black, J. I., Feasibility study of fluidic turbine temperature sensors in gas turbine engines, ASME, Annual Gas Turbine Conf. and Products Show 14th, Cleveland, Ohio, Paper 69-GT-70; A6922512 (Mar. 9 - 15).

Dunn, M. G., and J. A. Lordi, Development of freemolecular Langmuir probe for measurement of electron temperature and number density in shock tunnel flows, Cornell Aeronautical Lab., Inc., Buffalo, New York, CAL-AN-2101-Y-2; N69-24285.

D'yachkov, B. G., Measurement of flame temperatures from $\alpha$-ray energy loss, Teplofiz. Vys. Temp. (USSR) 5, No. 6, 1071 (Nov.).

Fam, S. S., L. C. Lynnworth, and E. H. Carnevale, Ultrasonic thermometry in LMFBR systems, Seventh quarterly progress report covering the period ending June, Panametrics, Inc., Waltham, Mass., NYO-3906-7; NSA-23:38351 (June).

Goring, G. E., and D. L. Hardison, An acoustical thermometer for the temperature range $300-700$ K, Rev. Sci. Instr. 40, No. 8, 1069 (Aug.).

Hoppe, J. C., Rotational and vibrational temperature measurements in the 12-inch hypersonic ceramic-heated tunnel, NASA-TN-D-4892; N69-10932 (Nov.).

Johnson, E. G., Fluidic gas turbine engine controls, Honeywell, Inc., Minneapolis, Minn., Aerospace Div.; N69-39145 (Sept.).

Lynnworth, L. C., Use of ultrasonics for hightemperature measurements, American Society for Nondestructive Testing, Meeting, Boston, Mass., Materials Evaluation 27, 60; A69-23373 (Mar.).

Mobsby, E. G., Practical ultrasonic thermometers, Ultrasonics $\underline{7}, 39$ (Jan.).

Nikolaenko, V. A., V. I. Karpukhin, and S. I. Alekseev, Temperature measurement by diamond indicators, Instr. Exp. Tech. (USSR) 6, 1586 (Nov. Dec.).

Shipley, D. G., and K. F. Torok, Passive microwave measurements of sea surface temperature, Final Report, Radio Corp. of America, Princeton, New Jersey, Astro Electronics Div., Contract N0001469-C-0245; AD-702044; N70-27958.

Vladimirov, N. K., and O. K. Lomakin, Temperatureindicating paint (USSR) Otkrytiya, Izobret., Prom. Obraztsy, Tovarnye Znaki 46, No. 12, 90.
Walliser, G., Fluidic temperature sensor investigations for high gas temperatures, DIAMLER-BENZ, A. G. Stuttgart (West Germany) N69-39143 (Sept.).

Williamson, R. C., and C. M. Stanforth, Measuremen of jet engine combustion temperature by the use of thermocouples and gas analysis, SAE, National Air Transportation Meeting, New York, N. Y., Paper No. 690 433; A69-41650 (Apr. 21 - 24).

Yevick, G. J., and R. Harvey, Experimental investigation of cusped containment geometrics, CHALICE-Semiannual report, (Mar. 1 - Aug. 31, 1969) Stevens Inst, of Tech., Hoboken, New Jersey, Dept. of Physics; N70-22064 (Aug. 31).

Decals turn black with heat and measure Apollo temperature to one percent Prod. Eng. 40, 137 (Mar. 10).

Model MET-2 Measuring electronic thermometer, National Oceanographic Instrumentation Center, Washington, D. C., Rept. No. IFS-69006; AD843441 L. 
8. Special Applications,

Method not Specified in Title

1964

Cato, G. A., Altitude measurement systems for pressure, density, temperature, and winds, Final Report, Electro-Optical Systems, Inc., Pasadena Calif., NASA-CR-70020; EOS-3780-Final; N66-16714 (Feb. - Nov.).

\section{5}

Alekseev, S. I., et a1, Method of measuring the temperature of objects of difficult access at time of operation, Foreign Technology Div. Wright-Patterson AFB, Ohio, FTD-TT-64-970; AD628300 (Nov. 5).

Allen, R. W., and R. F. Burch, The thin film thermometer as a triggering and measuring device in a shock tube, Atomic Weapons Research Establishment, Aldermaston, Eng. AWRE-0-58/65; NSA 20-618; N66-17541 (Oct.).

Anderson, R. M., Temperature determination in cold wall vacuum chamber, General Dynamics/Astronautics, San Diego, Calif. Rept. No. GDA-27A1398; AD-697408; N70-21266 (Oct. 9).

Armstrong, R. W., Improvement in accuracy of the ML-419 radiosonde temperature element for heights above 50,000 feet and up to 150,000 feet, Army Electronics Command, For Monmouth, N. J., Rept. No. ecom-2634; AD-624 855 (Oct.) .

Brodier, M. J., Temperature measurement and its practice in heat treatment, Traitement Therm. No. 18,25 (Nov. - Dec.).

DeLeo, R. V., and A. E. Saari, Study to determine suitable high temperature high altitude, total temperature sensors, Final Rept. NASA-CR-68875; N66-13968 (Nov. 5).

Dunhorne, E. H., The measurement and control of furnace temperatures, Wire Ind. 32, 763 (Aug.).

Grady, R. F., and M. G. Cramp, Direct measurement of generator winding temperature using a miniature transmitter, IEEE Trans. Power Apparatus and Systems 84, 1073 (Nov.).

Kurzinski, E. F., Temperature measurement at the hot strip mill, Iron \& Steel Eng. 42, 91 (Dec.).

Lyamin, E. A., et al, Use of towed thermistor chains for investigating the thermal structure of the sea, Okeanologiya 5 , No. 3, 553; N6610489 (Oct. 14).

Malin, W. J., J. Davison, and C. Krollman, Development of a deiced, fast response, dual element total temperature sensor, Rosemount Engin. Co., Minneapolis, Minn., Report No. REC-5644A; Contract AF33 600 42754; Project 8201; SEG TR-6536; AD-622 247,

Mansberg, H. P., Precision temperature measurement and display system, Patent 3,201,991 (Aug. 24).
Nikitin, P. G., and Yu. N. Sitnikov, Pyrometer for contactless measurement of temperature on the surface of a traction motor rotor when an electric locomotive is moving, Autom. Control and Methods of Elec. Meas. II, 223; N66-12233 (Dec.).

Novak, P. E., and R. R. Asamoto, Evaluation of thermocouples for use to $2600^{\circ} \mathrm{C}$ in mixed-oxide fuel, Trans. Am. Nucl. Soc. 8, 388 (Nov.).

Ogale, V. A., and A. J. Van Montfourt, Design and development of rotating slip ring assembly for cooled gas turbine blade temperature measurement, Technische Hogeschool, Delft (Netherlands) Report 10.E.0/0; N66-32103 (Dec.).

Pesaresi, R., and R. Frassetto, A compact thermometer for the study of microthermal structure from oceanographic buoys, Sacland ASW Research Centre, La Spezia, Italy, Report No. TR-46; AD474337 (Oct. 15).

Polosatkin, G. D., and S. A. Gribanov, Measurement of surface temperatures of tools at cutting speeds of 1-800 $\mathrm{msec}^{-1}$, Soviet Phys. J. (USA), No. 3, 123 .

Sterbutze1 G. A., A probe for the measurement of high surface temperatures, Cornell Aeronautical Lab., Inc., Buffalo, New York, AFFDL TR-65-121; AD-624888; N66-16682 (Sept.).

Stickney, T. M., Development of a fast response temperature gage for rocket vehicle plumbing systems, Fina1 Report, Rosemount Engin. Co., Minneapolis, Minn., Contract NAS8-11699; NASA CR-78446 (June).

Tschang, P. S., Temperature determination in moderately dense, high-temperature gases by transient thermocouple probes, Columbia Univ., New York, Electronics Research Labs., Contract No. AF33 (615) -1141; Report No. ARL-65-95; NSA 1943403; CFSTI.

Tsuchiya, S., and K. Kuratani, Temperature measurement of argon gas behind reflected shock wave, J. Chem. Phys. 42, 2986 (Apr.) .

Yankelev, L. F., and V. S. Roife, Accelerated thermocouple method of measuring thermal conductivity, J. of Eng. Phys. 8, No. 4, 355 (Apr.).

Young, L. A., Infrared temperature measurement of the laminar wake of a hypersonic sphere, AIAA J. 3, 610 (Apr.).

\section{6}

Alexander, W. E., Standardizing surface-temperature measurement, Proc. 12th National Soc. Am.'Aerospace Instr. Symp. 251.

Ballard, H. N., The measurement of temperature in the stratosphere and mesosphere, Atmospheric Sciences Lab., Missile Range, White Sands, New Mexico, Proj: DA-1-V-650212-A-127; Task: ECOM 5056; AD-639115 (May). 
Beetham, Carl V., Test and evaluation of the near surface reference temperature system, Naval Oceanographic Office, Wash. D. C., Report No. NOO-IM-66-10; AD-804 992L (Aug.).

Born, G. K., and R. G. Buser, Determination of the gas temperature in the after flow of pulsed discharges by microwave probing of standing acoustic waves, J. App1. Phys. 37, 4918 (Dec.).

Clemente, A, et al, Pressure and temperature measurements in shock driven facilities, Int. Congress on Instrumentation in Aerospace Simulation Facilities, 2nd Proc., Stanford Univ., Stanford, Calif., (Aug. $29-31$ ).

Colluci, S. E., and J. M. Adams, Flame temperature measurement of metalized propellant, AerojetGeneral Corp., Sacramento, Calif., Quarterly Report No. 3, AD-479 615 (Mar.).

DeVito, P. A., Remote temperature sensor and measurement telemetry system, Univ. of Pittsburg, Pa., Masters thesis; AD-481 443.

Eckstein, B., Concept of temperature and temperature measurement in glasses, Glastech. Ber. 39, 455 (Oct.).

El Agib, A. A., Thermometric methods of measuring the rate of mass flow, Proc. Automobile Div., Inst. Mech. Eng. (London) 180, No. 45, 1035.

Essers, E., U. Essers, and G. Heyer, Measuring piston temperatures by means of contactless data transmission, Motortech. Z. ATZ., 68, No. 9, 304 (Sept.).

Fabricant, S. J., et al, U1tracentrifuge ratio temperature measurements and control, Rev. Sci. Instr. 37, No. 4, 495 (April).

Fillo, J. A., Approximate solution to the flat plate thermometer problem, AIAA J. $\underline{4}, 1876$ (Oct.).

Frolovskii, I. L., Method of measuring the temperature field of a stream of exhaust gases, Foreign Technology Div., Wright-Patterson AFB, Ohio, Report No. FTD-TT-65-1944; AD-630 272 (Feb.).

Galdon, B. F., Special study of a method for attaching thermocouples to mortor tubes, Code A process, Development and Proof Services, Aberdeen Proving Ground, Md., Final Report No. DPS-2133; Proj: USATECOM-9-6-0023-19; AD-488 897L (Aug.).

Germann, R. W., and D. B. Rogers, Four-probe device for accurate measurement of temperature dependence of electrical resistivity on small irregularly shaped single crystals with parallel sides, Rev. Sci. Instr. 37, No. 3, 273 (Mar.).

Hearne, K. R., and S. A. Nixon, Method for measuring transient arc electrode temperatures, Brit. J. App1. Phys. 18, 325 (March).
Hsu, S. T., and H. S. Kao, The development, fabrication, and evaluation of a device for the measurement of thermal properties of soil, Final Report (June 64 - Jan. 66), Contract NBy32275; Proj. Y-F011-05-02-341; AD-632 080 (Jan.).

Kenda11, S. N, et al, Semiconductor surface thermocouples for determining heat transfer rates, Int. Congress on Instrumentation in Aerospace Simulation Facilities, 2nd Proc., Stanford Univ., Stanford, Calif., (Aug. 29 - 31).

Kowalewskaja, W. W., and W. K. Potapkin, Electroaccoustical transformer converting temperature into frequency, Feinwerk-Tech. 70, 340 (July).

Levy, A., Preliminary temperature measurements behind strong shock waves in argon, Toronto Univ., Ontario, Inst. for Aerospace Studies, UTIAS-119, AFOSR-67-1579; N67-39931.

Mason, J. B., A study of the feasibility of using radar chaff for stratospheric temperature measurements, Army Electron. Labs., Fort Monmouth, New Jersey, ECOM-5012; AD-473747; N66-13602.

Mikhnerich, V. V., Density and temperature of the atmosphere based on measurement results obtained on high altitude geophysical automatic stations in 1963, National Aeronautics and Space Administration, Washington, D. C. , Space Research, 25; N66-25688 (May).

Nowak, J., Temperature measurement of metal baths by immersion pyrometers, Przeglad Odlewnictwa 16 , No. 3,92 .

Reynolds, R. D., and R. L. Lamberth, Ambient temperature measurements from radiosondes flown on constant-level ballons, J. Appl. Math. Phys. 5, No. 3, 304, AD-672 391 (June).

Richards, T. L., and D. G. Massey, An evaluation of the infra-red thermometer as an airborne indicator of surface water temperatures, Dept. of Transport, Meteorological Branch Toronto, Ontario, Report No. CIR-4354, TEC-592; AD-481 469 (Jan.).

Roessler, F., Temperature determination in magnesium flames, Institut. Franco-Allemand d)e Recherches, St. Louis, France; N68-16158 (Sept.).

Schraeder, A. E., Measuremement of bath temperature in the basic oxygen furnace, Iron Steel Eng. 43, 137 (May).

Ser'ezhov, A. N., Method of measuring temperature under conditions of high noise leve1, Report No. NASA-TT-F-384; N66-122232.

Sloan, D. H., Exhaust-temperature monitor checks status of each engine cylinder, 0il Gas J. 64, 124 (May 9).

Springfield, R. R., Temperature profiling, Instr. Control Systems 39, 133 (May).

Stotter, A., et al, New method predicts exhaust valve temperature for diesels in design stage, SAE J. 74,49 (Feb.). 


\section{Special Applications}

Urboh, J., and M. Stehlik, Measuring the temperatures in pressure generators for city gas with thermocouples, CAECH. 118, 083 (C1. GOIK), Appl. (April 15).

Walker, R. F., Temperature measurement in high temperature chemistry, $1000-3000^{\circ} \mathrm{C}$, Rev. Int. Hautes Temp. Refract. 3, No. 1.

\section{7}

Abramavich, B. G., Measurement of surface temperature by means of thermoindicator, Teplofiz Vys. Temp. (USSR) 5, No. 3, 535 (May - June).

Azimov, R. K., et al, Method of measuring rapidlychanging temperatures, Izv. VUZov, Instr. Bldg. 9, No. 6, 31; N67-27829 (March).

Ballard, H. N., A review of seven papers concerning the measurement of temperature in the stratosphere and mesosphere, Atmospheric Sciences Lab., Missile Range, White Sands, New Mexico, Proj: BA-1-V-650212-A-127; Task: 1-V-650212-A12703; AD-656 461 (May).

Best, G., Upper atmosphere temperature determination using A 10 bands excited by the sun at twilight, Geophysics Corp. of Am., Bedford, Mass., Contract NASw-1083; NASA-CR-85808; GCATR-67-7-N; N67-31199 (May).

Bolton, C. B., and R. E. Simpson, A temperature sensing suit, Royal Aircraft Establishment, Farnborough, (England), RAE-TR-67280; N68-3400 9 (Nov.).

Burke, H., Thermally isolated temperature sensor for space application, NASA, Marshal1 Space Flight Center, Huntsville, Ala., Res. Achievements Rev. 1, 5; N67-30585.

Chatfield, E. J., A technique for accurate specimen temperature measurement in a thermobalance, J. Sci. Instr. 44, No. 8, 649 (Aug.).

Cormier, M., and F. Claisse, Technical notetemperature measurement during quenching of titanium, Can. Met. Quart. 6, 369 (Oct. - Dec.).

Deacetis, J., and D. C. Rousar, Development of temperature-indicating sensor for use in ablative rocket nozzles, Aerojet-General Corp. Sacramento, Calif., Phase report No. 1, Contract: F04611-67-C-0118; AD-827 922 (Oct.).

Des Champs, N. H., On the accuracy of measuring transient surface temperatures with embedded thermocouples, Ph. D. Thesis, Avail. Univ. Microfilms, Virginia Polytechnic Instr. Blacksburg; N69-10401.

De Vries, M. F., Measurement of drilling temperature by the garter spring thermocouple method, Microtecnic 21, No. 6, 583 (Dec.).

Ealey, E. H., and G. Ettershauk, Integration and recording of radio transmitted temperatures, Austrailian J. Instr. Control 23, No. 4, 127 (Nov.).
Eliseev, A. A., Receiver for measuring radiation temperature variations in the atmosphere, Glavnaia Geofizcheskaia Observatoriia imeni A. I. Voeikova, Trudy, No. 204, 173; A68-14924.

Gautrot, D., A temperature probe for high-enthalpy flow, NATO-AGARD, Reunion sur les Nouvelles Techniques Experimentales, 30th; Munich, Germany, ONERA, TP No. 484 (Sept. $11-15$ ).

Girfa, J. B., A unique tool for undersea thermometry, the thermister chain, Navy Electronics Lab., San Diego, Calif., Undersea Technology Report No. Reprint-R-199; AD-657 513 (May).

Gordiyenko, V. V., and R. I. Kutas, Transistorized thermometers for temperature measurements in bore holes, Phys. Prop. of Crastal Substances, 37; Akad. Nauk (URSR) Kiev; N69-36819.

Grey, J., and P. F. Jacobs, Cooled electrostatic probe, AIAA J. $\underline{5}$, No. 1, 84. (Jan.).

Hanse1, J. G., and S. Y. Lee, Technique for measuring emittance of polymers at elevated temperature, Appl. Spectro'y 21, No. 4, 261 (July Aug. ).

Haroules, G. G., and W. E. Brown, III, Techniques for absolute temperature measurements at microwave frequencies, Rev. Sci. Instr. 38, No. 8 , 1093 ; N67-35599 (Aug.).

Harvey, W. D., Instrumenting models for aerodynamic heat-transfer studies involving transient heating rates, ISA: Instr. Soc. Am. 6, No. 1,42 .

Hearne, K. R., and S. A. Nixon, A method for measuring transient arc electrode temperatures, $\mathrm{Br}$. J. Appl. Phys. 18, No. 3, 325 (March) .

Kelkar, M. A., Temperature measurement of molten steel, Get-Together on Thermometry, Nat. Phys. Lab., New Delhi, Pap. 5.1 (13 - 17 Feb.).

King, P. J., D. F. Cotgrovs, and P. M. Słate, Infrared method of estimating the residual temperature of shocked metal plates, Atomic Weapons Research Establishment, Aldermaston, England, Symp. High Dyn. Pressure, Paris (Sept. $11-15$ ) N68-12201.

Koch, B., and H. Oerte Jr., Microwave thermography, Z. Naturforsch, a 22, 270 (Feb.).

Kondelik, P., J. Horak, and J. Pasek, Temperature measurements by means of a probe in a catalyst bed, Chem. Listy 61 , No. 3, 382 .

Kon'kov, A. A., A. P. Riazin, and V. S. Rudnev, Measurement of the air temperature behind a reflected shock in the $20-30$ mach number range of the incident shock, Lockheed Missiles and Space Co., Palo Alto, Calif; N67-27737.

Korneff, T., Study of high energy, high discharges and high temperature measurements as applied to exploding wires, Temple Univ., Dept. of Physics; 


\section{Special Applications}

Philadelphis, Pa.; Contract No. AF 19(628)-215 (16); Final Report, Mar. 1, 1962; AD-652 237; N67-32725; (May 1).

Kozhin, V. M., Halite "thermometer" for x-ray study of materials from 77 to $1037^{\circ} \mathrm{K}$, Instr. Exp. Tech. (USSR) 1, 194 (Jan. - Feb.).

Kukonin, V. E., Methods of measuring plasma temperature in "Teploelektricheskie Izmerencia I. Kontro1", edited by I. F. Voloshin; Minsk, Izdate1' stvo Nauka Tekhnika; A67-40216

Loughran, D. J., L. Schott, and H. M. Skarsgard, Orbit analyzer probes for the measurement of plasma temperatures, Can. J. Phys. 45, 3055 (Sept.).

Marlatt, W. E., Remote and in situ temperature measurements of 1 and and water surfaces, J. Ap. Meteoro1. 6, 272 (April).

Martin, D. L., Use of pure copper as a standard substance for low temperature colorimetry, Rev. Sci. Instr. 38, No. 12, 1738 (Dec.).

Mitche11, D., et al, The selection of a biothermal radiometer, J. Sci. Instr. 44 , No. 10, 847 (Oct.).

Mochalov, V. K., Device for measuring the temperature of the overheating of the revolving parts of machines, Air Force Systems Command, WrightPatterson AFB, Ohio, FTD-TT-65-1939; AD-63152; N67-10973.

Nichols, G. A., and P. Verhonik, Time and temperature, Walter Reed Army "Inst. of Research, Washington, D. C. Am. J. Nursing 67, No. 11; AD-663 988 .

Redding, J. L., Temperature of a moving body, Nature (G. B.) 215, 1160 (Sept. 9).

Sherrard, R., High speed scanning system temperature monitor, Douglas United Nuclear Inc., Richland, Washington; DUN-SA-32; CONF. 670319-1.

Shiroki, K. I., Automatic control system for crystal growth by the flame fusion method, Rev. Sci. Instr. 38, 1541 (Oct.).

Slezenko, Z. F., Temperature field measurement of thin objects, Joint Publ. Research Service, Washington, D. C., Izv. VUZ. Instr. B1dg. 9, No. 2,129, N67-28126 (Feb. 23).

Spitzer, C. R., Pyroelectric heat-transfer sensors for hypersonic impulse facilities, IEEE Trans. on Aerospace and Electronic Systsms AES-3, 349 (March).

Stanislao, J., H. O. Baudisch, and M. H. Richman, Temperature control in machining, Instr. Cont. Syst. 40, 101 (Aug.).

Tikhonov, A. N., and V. B. Glasko, Methods for determination of temperatures of solid surfaces, Zn. Vychislit. Mat. Fiz. (USSR) 7, No. 4, 910 (July).
Van Trong, N., Determination of the temperature of a wire-explosion plasma, C. R. H. Acad. Sci. Ser. B: Ph. (CHDBAN) 265, No. 3, 187 (July 17).

Vasilakas, J. D., Measurement of temperatures due to sliding in ultra-high vacuum, Ph. D. Thesis; Rensselaer Polytechnic Inst., Troy, New York, Avail: Univ. Microfilms; Order No. 68-849; N6912768 .

Watson, G. G., and R. D. Clark, Determination of the tube-wall temperature in a heat exchanger from the tube resistance, National Engineering Lab. , G1asgow, Scot1and, NEL-272; NP-17095; N68-14715 (Jan.).

Williams, I. P., Temperature of a moving body, Nature (G. B.) 213, 1118 (Mar, 18).

Wilson, J. W., and J. H. Wagner, A new technique for measuring electron temperature and measurements of electron temperature in the lower ionosphere at sunset, COSPAR, Plenary Meeting, 10th, London, England, (July 24 - 29).

\section{8}

Bentley, P. G., and R. Rowley, Comparison of the frequency responses and time constants of mineral insulated thermocouples in sodium and water, Meas. Control 1, No. 5, T100-T104 (May).

Bergman, P., and W. K. Bullinant, A compression heating device for agent tolerance studies, III, Thermocouple response study, Fort Detrick, Frederick, Maryl and, Rept. No. SMUFD-TM-127; AD-828 737 (Jan.).

Bogue, R. K., and L. D. Webb, Advanced air data sensing techniques, NASA, Flight Research Center, Edwards AFB, Calif., International Aerospace Instrumentation Symposium, 5th, Cranfield Beds, England, Proc.; A69-16755 (Mar. $25-28$ ).

Bovsheverov, V. M., and M. I., Mordukhovich, Acoustical thermometer-interferometer for temper ture measurements in the stratosphere Akad. Nauk (USSR) Inst. Fiziki Atmosfery, Moscow, Izvestiia, Fizika Atmosfery i Okeana, 4, 1019; A69-13269 (Octw).

Campbe11, W. J., Earth resources survey program: synopic temperature measurement of a glacier lake and its environment, NASA-Manned Spacecraft Center, Houston, Texas, NASA-TM-X-61714; N69-28506 (Feb.).

Carden, P. 0., et al, A stationary contacting thermocouple device for measuring the temperature of rapidly-moving surfaces, Dept. of Engineering Physics, Australian Nat. Univ. Canberra, Australia, J. Sci. Instr. S2, No. VI, 757 (July).

Cassidy, J. F., and W. M. Krawczonek, Accurate surface temperature measurements at liquid helium conditions in space environment facilities, National Aeronautics and Space Administration Lewis Research Center, Cleveland, Ohio, NASA-TMX-52386; N68-17044 (March). 


\section{Special Applications}

Caleby, P. R., Radiation thermometer for temperatures greater than $100^{\circ} \mathrm{C}$, Mullard Technical Communications 10, No. 93, 91 (May).

Cook, G. E., and W. M. McCampbe11, Intrinsic thermocouple monitors welding, Metal Progress 93, 176; A68-31376 (June).

Crompton, R. H., P. M. Nave, and G. Coste11o, Analysis of free air temperature sensing, Franklin Inst., Research Labs., Philadelphia, Pa. Final Rept. No. F-C1959; Contract: F33615-67-C1128; Proj: AF-8222; Task: 822207; AD-829 748 (Feb.).

Curtis, C. D., NUWC temperature calibration facility: recent improvements and interorganizational cross-calibration results, Naval Undersea Warfare Center, San Diego, California, NUWC-TP27; AD-671 193 (Feb. 8).

Daniels, G. E., Errors of radiosonde and rocketsonde temperature sensors, American Meteorological Society Bul1. 49, 16; A68-19712 (Jan.).

Day, G. W. , O. L. Geddy, and R. J. Iversen, Detection of fast infrared lasar pulses with thin film thermocouples, Illinois Univ., Dept. of Elect. Eng., Urbana, I11., Contract No. AF-AFO SR-390-67; AD-684226 (Sept.).

Essers, E., U. Essers, and G. Heyer, Measurement of piston temperatures. Part 1, A new technique using NTC resistors and pulsed inductive coupling, Naval Scientific and Technical Information Centere London, England, Report No. NSTIC-TRANS-1859; NSTIC-16421/68; AD-832870 (March).

Fanel1i, M., Measuring internal temperatures in mass concrete, Water Power 20, 155 (Apr.).

Fuchs, M., and C. B. Tanner, Surface temperature measurements of bare soil, J. Appl. Meteorol. 7, No. 2, 303 (Apr.).

Hayaski, M., and T. Tachikama, End point temperature and carbon control with a dropping thermocouple and carbon detector in the molten bath of the Linz-Donawitz converter during blowing Tetsu To Hagane 54, No. 4, 541 .

Hayes, D. J., The sensitivity of the thermistor katharometer, J. Sci. Instr. 1, No. 7, 761 (July).

Herget, W., Temperature and concentration measurements in model exhaust plumes using inversion techniques NASA Mal. Radiation and its appl. to diagnastic tech., 359; N68-18100 (Jan. 8).

Holmes, P., A precise temperature measuring apparatus for use in a metrology laboratory, Microtecnic 22, No. 2, 121 (Apr.).

Kennealy, W. A., Shipboard engineering plant sensing system for control input., Final Report of temperature sensing subassembly phase, Naval Ship Engineering Center, Philadelphia, Pa. Report No. NAVSECPHILADIV-A-975; AD-839 836L (July).
Kogan, A. V., and M. I. Bantsur, Pyrometer for measuring temperatures below $800 \mathrm{C}$, Foreign Technology Div., Wright-Patterson AFB, Ohio, Report No. FTD-HT-23-113-68; AD-682170 (June) .

Konozenko, I. D., and Zh. A. Zaika, Device for remote measurement of temperatures, Institute of Physics, Academy of Sciences of the Ukrainian SSR, Ḱ̃ev, Prib. Tekh. Eks No. 2, 226 (March April).

Kopke, G., A novel technique for measuring piston temperature, Motortech. Z. 29, No: 7, 299 (July).

Kuehn, L. A., and R. S. Weaver, A system for recording temperatures in the vicinity of liquid surfaces, Defence Research Establishment, Toronto, Ontario, J. Sci. Instr. (J. Phys. E), 1, Ser. 2, 776; AD-677127 (Mar.).

Kuehn, L. A., Evaluation of a direct reading instrument for measuring the wet bulb-globe temperature index, Defence Research Establishment, Toronto, Ontario, Report No. DRET-692; AD-862 379 (Sept.).

Kuhn, G. D., Determination of radial temperature profiles in an axially symmetric propane-air diffusion flame, Northwestern Univ., Evanston, I11., Ph. D. Thesis; N69-29400.

Luethge, J. A., Measurement and control of temperatures in rotary kilns, Instrum. Technol. 15, No. 3, 46 (Mar.).

Mach, H., and J. Vauvrecy, Temperature measurement in the wake of a sphere shot at hypersonic velocity, Institut Franco-Allemand de Recherches, St. Louis, France, Rept. No. ISL-T-33/66; N6816146 (Nov. 29).

Mach, H., Temperature measurements of flame jets from erosion bombs; Rept. No. ISL-T-21/67; N69-17920.

Mikhailenko, L. I., et al, Measurement of the temperature of moving droplets, Templo-Massoobmen, edited by V. I. Tolubinskii, 136, Kiev, Izdatel'stvo Naukova Damka; A69-15423.

Moffat, R. J., Temperature measurement in solids, Stanford Univ., Stanford, California, Paper No. 68-514 (Oct. $28-31$ ).

Ostertag, W., and G. R. Fischer, Temperature measurements with metal ribbon high temperature $x$-ray furnaces, Rev. Sci. Instr. 39 , No. 6, 888 (June).

Otter, A. J., Thermocouples and surface temperature measurement, Atomic Energy of Canada, Ltd. Chalk River, Ontario, AECL-3062; N68-24123 (March).

Poncins, A., Temperature measurement of fuel element clads with thermocouples, Energie. Nucl. (Paris) 10, 381, NSA-23:11357 (Oct.). 


\section{Special Applications}

Purslow, D., and M. Hussey, An air temperature probe for convective heating tests, Royal Aircraft Establishment, Farnborough, England, Report No. REA-TR-68036; AD-840626 (Feb.).

Robertson, T. L., Modern clinical temperature measurement, Consolidated Electrodynamics Corportion, Monrovia, California, ISA Trans. 7, No. 2, 112 .

Sauer, R., Accurate temperature matching in calorimetry, J. Sci. Instr. 1, No. 6, 682 (June).

Sclater, N., DC motor chops ir beam as unit takes temperature, Prod. Eng. 39, 44 (Dec. 16).

Shcherban, A. N., and N. I. Furman, Thermogradient measurements in deep boreholes, Akad. Nauk (USSR) Kiev.; Mining Thermophysics, 85; N70-16597.

Softley, E. J., Use of a pulse heated fine wire probe for the measurement of total temperature in shock driven facilities, Gen. Electric Co., Missile and Space Div., Philadelphia, Pa., Report No. 68SD2; Contract: AF 04(694)-772; AF 04 (694)-897; AD-826149 (Feb.).

Stalony-Dobrzanski, J. A., et al, Temperature sensor development for temperature rate flight control system, Northrop Corp., Hawthorne, California, Narair Div., Report No. NOR-67-223; AD-833824 (Feb.).

Taylor, N. B., L. A. Kuehn, and M. R. Howat, A direct reading mecury thermometer for the wet bulb temperature index, Defense Research Establishment, Toronto, Ontario, Report No. DRETRP-702; AD-685891 (July).

Verdish, E. N., and M. B. Mints, Device for recording small ambient temperature variations, Meas. Tech. No. 11, 1481, Translation of Izmeritelnaya Tekhnika No. 11, 28 (Nov.).

Voskoboinikov, I. M., et al, Determination of the temperature of organic substances in shock waves, Dokl Akad Nauk (USSR), 182, 807; A6911979 (Oct.).

Walker, J. D., and B. J. Stocks, Thermocouple errors in forest fire research, Fire Technol. 4, 59 (Feb.).

Model 2832A temperature sensor assembly, National Oceanographic Instrumentation Center, Wash. D. C; Report No. IFS-69001; AD-873436L (Aug.).

Device for continuously measuring the temperature of hot media, British Patent No. 1,137,432 (Dec.).

Determine piston-wall temperatures, Electronics 41, 146 (Nov. 25).

\section{9}

Bourman, B., and H. Edels, Radial temperature measurements of alternating current arcs, Brit. J. App1. Phys. 2, No. 2, 53 (Jan).
Bradley, W., and P. Boaker, Development of a temperature indicating sensor for use in ablative rocket nozzles, Aerojet-General Corp., Sacramento, Calif.; AD-857813 (July).

Buger, P. A., and W. Scheuermann, Measurement of excitation temperatures in a high-current hollow cathode, Nat. Physical Res. Lab., Pretoria, S. Africa, Z. Physik 216, No. 3, 248.

Byuro, E. D., et al, Instruments for measuring partial concentrations, temperatures and pressure in the upper atmosphere, Collection of Articles on Instrumentation for Studying upper atmosphere, 51, Oct. 27; N69-10257.

Dixon-Lewis, G., and G. L. Isles, Flame structure and flame reaction kinetics. III. Measurement of temperature profiles in flames at atmospheric pressure, Houldsworth School for Applied Sci., The Univ., Leeds, Eng., Proc. Roy. Soc. (London) 308, No. $1495,517$.

Ellison, J. R., and H. I. Binder, Evaluation of rocket nozzle passive temperature indicators, Air Force Rocket Propulsion Lab. Edwards AFB, Calif. Rept. No. AFRPL-TR-69-181; AD-861814 (Sept.).

Galbreath, J. M., Crystal sensor dewpoint temperature, Instrum. Tech. 16, No. 10, 101 (Oct.).

Garton, R. E., Temperature measurement for aircraftturbine-engine development, Exp. Mech. 9, No. 27N; A67-33898; A69-28886 (May).

Hearne, K. R., and S. A. Nixon, Electrode temperatures of carbon and graphite arcs, Brit. J. Appl. Phys 2, No. 2, 413 (Mar.).

Herchakowski, A., Life and performance characteristics of PB-TE couples in hydrocarbon fired systems, Army Electronics Command, Fort Mommouth, N. J., Rept. No. ECOM-3199; AD-699312 (Dec.).

Happe, J. C., Rotational and vibrational temperature measurements in the 12 inch hypersonic ceramicheated tunnel, NASA-TN-D-4892; N69-10932.

Johnson, J. L., Turbine inlet temperature measuring system, Honeywell Inc., Minn., Aerospace Div., Rept. No. 20574-FR-VOL-1; AD-865059 (Nov.).

Kirsten, C., Equipment for measuring the surface temperature of microscopic specimens, Centre for Molecular Electronics, Dresden, E. Germany, Jena Rev. (Germany) No. 3, 178

Larson, M. B., and E. Nelson, Variables affecting the dynamic response of thermocouples attached to thinskinned models, J. Heat Transfer, Trans. of ASME Series C 91, No. 1, 166, Tech. Briefs (Feb.).

Lillicrap, D. C., and J. K. Harvey, Electron-beam rotational temperature measurements including the effect of secondary electrons, AIAA J. 7, 980 (May).

Londan, A. L., and D. V. Nelson, A new dimension in hydraulic machinery testing with the quartz 
crystal thermometer, Stanford Univ., Calif. Dept.

of Mech. Eng., Report No. TR-72; AD-695400 (Aug.).

Ludwig, D., Measurement of the ion temperature in a hydrogen arc by means of the thermal Dopplar effect, Inst. of Plasma Physics, Garching W. Germany, IPP-3/88; N69-28049 (Mar.).

Mc Elligott, J. G., The design and construction of a thermal system to measure small temperature charger in the brain, Calif. Univ., Space Biology Lab., Los Angeles, Calif., Paper presented at the 7 th Temp Meas. Society Conferences, Hawthorne, Calif., NASA-CR-106386; N69-40603 (Apr. 21 ᄂ 22).

Pelepeichenko, I. P., and O. V. Dyakovskii, Selection of the length of a thermocouple measuring instantaneous temperature in nonstationary gas flows, Foreign Tech. Div. Wright-Patterson AFB, Ohio, Rept. No. FTD-HT23-157-69; AD-694853 (May).

Pepper, L., Precision of quartz crystal and mercury differential thermometers in heat-ofhydration test, Army Engineer Waterways Experiment Station, Vicksburg, Miss. Rept. No. AEWES-MISC Paper C-69-11; AD-692794 (Ju1y).

Ponomarev, V. N., et a1, Measurement of the ion temperature in a rarefied multicomponent plasma, Geomagnetizm Aeronomiya 9, No. 4, 625; A69-41839.

Postol'nik, Iu. S., Calculation of the temperature of a plate cylinder heated simultaneously by radiation and connection, Inzh. Fiz. Zhu. 16, 1082, A69-38641 (June).

Richards, F. A., and D. Walsh, Time-resolved temperature measurement of a laser-heated surface, Brit. J. App1. Phys. 2, No. 2663 (May) .

Vershinskii, N. V., Vibratory temperature sensor, Foreign Technology Div., Wright-Patterson AFB, Ohio, Rept. No. FTD-HT-23-1397-68; AD-697611 (Apr.).

Zernov, I. A., Contactless measurements of the temperature of titanium-alloy billets during radiation heating., Meas. Tech. (USSR) $\underline{8}$, 1094 (Aug.). 


\section{Nuclear Applications of Temperature Measurement}

1964

Dallman, A. C., Mechanical reliability and thermoelectrical stability of noble-metal thermocouples at 2600F temperature and dose rates up to 10 to 20 power Nvt., Systems Engineering Group, Research and Technology Div., WrightPatterson AFB, Ohio, GEMP-183, rev., Proj. 125A, Task ORC7, SEG TDR64 7 (Apr.).

\section{5}

Babbe, E. L., Increasing thermocouple reliability for in-pile experiments, At. Intern., Canoga Park, Calif., Report No. NAA-SR-10511; N6523024 .

Bliss, P., Status of instrument development for the Snap-50 reactor test program, Pratt \& Whitney Aircraft, Advanced.Nucl. Eng. Lab., Middletown, Conn., Rept. No. PWAC-473; AEC Accession No. 44348 .

Brindley, J. H., Evaluation of thermocouple thermal-loading errors for a surface-attached thermocouple on a flat plate fuel element, Atomics International, Canoga Park, Calif., Nucl. Sci. Eng. 23, 313 (Dec.).

Dale, W. B., et al, Instrumentation of nuclear reactors, British Patent $1,139,722$. Filed (Mar.).

Frankel, R. R., et al, Cerium magnesium nitrate temperature scale from nuclear orientation, Phys. Rev. 140, Al020 (Nov. 1).

Ham, A. C., and R. E. Jones, Some measurements on thermocouples subjected to radiation, Sci. Tech. Aerospace Rept. 3, No. 14, 2369, Rept. No. RAE-TN-STRUCT-343; N65-25351.

\section{6}

Bianchi, G., P. Lupoli, and S. Moretti, Behavior of irradiated thermocouples. Experimental investigations, Com. Noz. Energ. Nucl., No. RTING 14 .

Brodi, G., A. E. Abbott, and J. C. Koch, Controlling furnace cycle with infrared pyrometers in the casting of large uranium ingots, Natl. Lead Co. of Ohio, NLCO-970; NSA 20, No. 9 (May 15); N66-11379.

Brooks, E. J., and W. C. Kramer, Tungstenrhenium alloy thermocouples and their use in a $\mathrm{UO}_{2}$ fueled reactor, Argonne Natl. Lab., Idaho Fal1s, Idaho, Rept. No. ANL-6981; NSA 20, No. 10 (May 31).

Brooks, E. J., Reactor fuel temperature and thermal time constant measurements with tungsten-rhenium thermocouples, ISA Trans. 5, No. 3, 217 (July).

Cunningham, G. W., and W. H. Goldthwaite, Contribution to the meeting on high temperature thermometry, High temperature thermometry; paper presented at a seminar at AEC Headquarters, Washington, D. C., on February 24 - 26, 1965 (WASH 1067; TID-4500) Washington: Division of Reactor Development and Technology, U. S. Atomic Energy Commission, 1966; N67-19637 (Mar.).

Ehringer, H., C. Mongini-Tamagnini, and C. Ponti, Thermocouple composition changes due to neutron irradiation, Eur. At. Energy Community, EURATOM EUR-3156e; N67-23093 (Oct.).

Fairchild, C. I., et al, Vapor deposition in the fabrication of fission thermocouples, Los Alamos Scientific Lab, N. Mex., Contract W-7405-eng-36; (CONF-680202-5) CFSTI.

Gottschlich, R., and M. Bellezza, EMF deviation of Chromel/Alumel thermocouples caused by neutron irradiation, Eur. At. Energy Community, Petlen, Netherlands; N67-24585 (Dec.).

Grishchenko, A. Z., et al, Measurement of temperatures of reactions in tubular reactors, Khim. Prom. Ukr. 4, 51 .

Kinter, L. L., et al, Superheater fuel thermocouple calibration tests (711A) and Radiation Cooling Tests (723) Contract No. AT-(11-1)-289, Rept. No. (ACNP-66570) CFSTI; N67-25523 (Nov.).

Krivtsou, V. A., G. I. Gushchin, and A. A. Fraktovnikova, Methods of measuring temperatures in nuclear reactors, Teplofiz. Vys. Temp. 4, No. 2, 279 (Mar. - Apr.) (Russian). English träslation in High Temp. (U. S. A.) 4, No. 2, 272 (Mar. - Apr.).

Leonard, J. H., and J. S. Crutchfield, Transient radiation effects on thermocouples, Cincinnati Univ., Ohio, Grant No. NGR-36-004-014; (NASACR-83079) N67-23465 (Oct. - Nov.).

Leonard, J. H., and D. B. Hunkar, Direct radiation effects on thermocouples, Nucl. Appl. 3, 718, Grant No. NGR-36-004-014 (Dec.).

Leonard, J. H. , and J. S. Crutchfield, Transient radiation effects on thermocouples, Cincinnati Univ., Ohio, Grant No. NGR-36-004-014; (NASACR-81333) N67-16632.

Novak, P. E., and R. R. Asamoto, Out-of-pile evaluation of $W-R e$ thermocouple systems for use to $4700^{\circ} \mathrm{F}$ in $\mathrm{Pu} 02-\mathrm{U}_{2}$, U. S. At. Energy Comm., GEAP-5166; N67-23567.

Popper, G. F., and A. E. Knox, Faret in-core instrument development, Argonne National Lab., I11., ANL-7161; NSA 21-15762 (July).

New assembly gives better reactor temperature profiles, 0il Gas J. 64, 132 (Aug.).

1967

Anderson, J. D., Reduction of radiation effects on thermocouples in thermal vacuum testing, Proc. Inst. Environmental Sciences 13 th Annual Technical Meeting, Wash. D. C., 1; A67-25676 (Apr. $10-12$ ). 
Billeter, T. R., and D. P. Brown, Microwave measurement of high temperatures within nuclear reactors, Interim Report No. BNWL-399 (BattelleNorthwest) Richland, Washington; Contract No. AT (45-1) 1830; CFSTI.

Brodsky, A. A., et al, Low temperature thermometry based on the phenomena of temperature dependence on sound velocity, the level of thermal noise of electric resistances and frequency of nuclear quadrupole resonance (NQR) Get-Together on Thermometry, Nat. Phys. Lab., New Delhi, Pap. 1.7 (13 - 17 Feb.).

Callen, R. C., L. P. Prouteau, and A. J. Friedland, Response of fermi fuel subassembly outlet thermocouples under normal and fuel-failure conditions, Trans. Au. Nucl. Soc., 10,637, (Nov.).

Edward, J. T., J. C. Male, and P. F. Chester, On the suitability of liquid semiconductors for resistance thermometry in nuclear reactors, Central Electricity Research Laboratories, Leatherhead, Surry, Eng., J. Sci. Instr. 52, (VI), 469, (Apr.).

Fasano, A. N., L. B. Hary, and K. R. Hooks, Fuelplate temperature measurements at the air force nuclear engineering test facility, Trans. Amer. Nucl. Soc. 10, 16 (June).

French, R. L. D., Some preliminary results and comments on the use of nitrogen-16 for measuring channel outlet temperature in gas cooled reactors, United Kingdom Atomic Energy Authority, Windscale Eng., (PG-790(W); N67-38924.

Funstan, E. S., and W. C. Kuhlman, High temperature thermocouple and electrical materials research, General Electric Co., Cincinnati, Ohio, Nucl. Sci. Abstr. 21, No. 6, NSA 21-9139; GEMP-61 (Mar. 31).

Hancock, H., Use of noble and refractory metal thermocouples in experimental irradiation equipment, International Symposium on Capsule Irradiation Experiments, Pleasanton, Calif., May 3-5, 1966, 7.1, 1 - 5; Conf. -660511; Nuc1. Sci. Abstr. 21, No. 12, NSA 21-19796.

Helm, J. W., Irradiation effects on thermocouples, International Symposium on Capsule Irradiation Experiments, Pleasanton, Calif., May 3 - 5, 1966, 7.3. 1 - 5; CONF-660511; Nucl. Sci. Abstr. 21, No. 12, NSA 21-20533.

Huck, C. E., Thermocouple development for the fastflux test facility, Battelle-Northwest; Richland, Wash. Pacific Northwest Lab., BN WL-SA-1227; CONF-670903-11; N68-11478.

Knox, A. E., and G. F. Popper, Fuel-pin thermocouple hot-zone errors at temperatures up to $2400^{\circ} \mathrm{C}$, Trans. Am. Nucl. Soc. 10, 309 (June).

Kolac, M., Nuclear methods of low-temperature thermometry, Inst. of Nuclear Research Czechosolovak Academy of Sciences, Rez.: Svec, Karel; Sebek, Josef. Jad, Energ. 13, 129, (Apri1).
Lauritzen, T., and F. A. Comprelli, Determination of maximum temperatures attained in irradiation experiments, Nuc1. Appl. 3, 390, (June).

Leonard, J. H., and D. B. Haunkar, Direct radiation effects on thermocouples, Nucl. Appl. 3, No. 12, 718, (Dec.).

Novak, P. E., and R. R. Asamoto, Thermocouple development for uses in measuring oxide fuel temperatures in-pile above $4000^{\circ} \mathrm{F}$., International Symposium on Capsule Irradiation Experiments, pleasanton, Calif., May 3 - 5, 1966, 7.5. 1 - 6; CONF-660511; Nucl. Sci. Abstr. 21, No. 12, NSA 21-20534.

Patane, M., Thermocouple failures in graphite irradiation rigs for $\mathrm{Br} z$ reactor, mol., Centre d' Etude de 1'Energie Nuclearie, Mol. (Belgium) (May 11).

Popper, G. F., and A. E. Knox, The materials selection problem as related to thermocouples used to measure nuclear fuel pin temperatures up to $2800^{\circ} \mathrm{C}$, Trans. I.E.E.E. NS-14, 1, 333, (Feb.).

Roes, J. B., and D. L. Peat, The development of an accoustical thermometer for a graphite matrix nuclear fuel element, I.E.E.E. Trans. Nucl. Sci. NS-14, 348, (Feb.).

Schreiber, R. E., Gamma thermometers, International Symposium on Capsule Irradiation Experiments, Pleasanton, Calif., May 3 - 5, 1966, 6.3.1 - 15) CONF-660511; Nucl. Sci. Abstr. 21, No. 12, NSA 21-19797.

Skaggs, S. R., W. A. Ranken, and A. J. Patrick, Decalibration of a tungsten-tungsten 25 rhenium thermocouple in a neutron flux, Los Alamos Scientific Lab., N. Mex. Contract W-7405-eng.-36; CFSTI (Jan.).

Utton, D. B., Nuclear quadrupole resonance thermometry, Metrologia 3 , No. 4, 98 (Oct.).

Verma, J. K. D., and B. D. Nag, Nuclear radiation effects in semiconductor and temperature measuring devices, Get-Together on Thermometry, Nat. Phys. Lab., New Delhi, Pap 4.6 (13 - 17 Feb.).

Watkins, R. A., Thermomolecular pressure difference measurements for precision $\mathrm{He}-3$ an $\mathrm{He}-4$ vaporpressure thermometry, J. Chem. Phys. 46, 1007, (Feb.).

Wood, V. E., Thermal neutron transmutation effects on $W / W-26$ Re thermocouples, J. Ap. Phys. 38, 1756, (Mar.).

Low-temperature measurements using nuclear quadrupole resonance, Engineering 204, 548, (Oct.).

\section{8}

Aleksandrowicz, J., et al, Cladding temperature measurements of the EK-10 type reactor fuel rods in EWA-2 care, Polish Academy of Sciences, Warsaw, Rept. No. $879 /$ X1/R; N68-30817. 


\section{Nuclear Applications}

Baxter, W. G., and W. C. Kuhlman, Fast breeder reactor thermocouple development, General Electric Co., Cincinnati, Ohio; Fuels and Materials, Development Program, 253; N69-38835 (Sept. 30).

Brauton, C. B., D. N. Ha 11, and C. M. Ryal1, Estimation of the compositional and volume changes in noble and refractory metal alloys due to neutron irradiation, Met. Div., At Energy Res. Estab., Harwe11, Eng1., U. K. At. Energy Authority, Res. Group. Rep. No. AERE-R5837.

Dau, G. J., R. R. Bourassa, and S. C. Keeton, Nuclear radiation dose rate influence on thermocouple calibration, Nuc1. App1. 5, No. 5, 322 (Nov.).

Dehn, R., Measurements of temperature and nuclear heating in reactors: a survey, Conference on Nucleanic Instrumentation, Reading, Eng., CONF680939; NSA-23: 24038.

Droege, J. W., et al, Refractory-metal thermocouples in nuclear and high temperature applications, Battelle Memorial Inst., Columbus Ohio BMI-X-10246; NSA-28:8148 (Nov. 22).

Edward, J. T., J. C. Male, and P. F. Chester, On the suitability of liquid semiconductors for resistance thermometry in nuclear reactors, J. Sci. Instr. 1, No. 4, 373 (Apr.).

Fam, S., L. C. Lynnworth, and E. H. Carnevale, U1trasonic thermometry in LMFBR Systems, Second Quarterly Progress Report Jan. 1 - Mar. 31. Panametrics, Inc., Waltham, Mass., NYO3906-2; Contract AT(30-1)-3906; avail. CFSTI (Apr.).

Funston, E. S., and W. C. Kuhlman, Fast breeder reactor thermocouple development, General Electric Co. Cincinnati, Ohio, GEMP-1004.

Hesse, J., Investigation on the influence of neutron irradiation on the thermo-electric properties of doped Ge-Si alloys, Z. Angew. Phys. 25, 331, NSA-23:2735 (Nov. - Dec.).

Huck, C. E., FFTF Coolant thermocouple development, (Presented at ERA/ISA Symp., Seattle, Pacific Northwest Lab., Battelle-Northwest Richland, Wash., Contract AT(45-1)-1830; BNWLSA-1857; CONF-680526-1; N68-37160 (May 14).

Kovach, J. L., The evaluation of the ignition temperature of activated charcoals in air, steam, oxygen and oxides of nitrogen, North American Carbon Inc., Columbus, Ohio, Symp. on Operating and Developmental Experience in the Treatment of Airborne Radioactive Wastea, New York, CONF-680811; NSA-23:29072.

Novak, P. E., and R. Q. Asamoto, An in-pile evaluation of $W$-Re thermocouple systems for use to $4700^{\circ} \mathrm{F}$ in sefor fue 1 , General Electric Co. Sunnyvale, Calif. Advanced Products Operation, GEAP-5468; N 69-34401 (Oct.).
Poncins, A., Temperature measurement of fuel element clads with thermocouples, Energ. Nucl. (Paris) 10, 381 (Oct.).

Stillman, D. B., and R. L. Chaney, Recent advances in fast-response miniature neutron flux monitors, Los Alamos Scientific Lab, New Mexico, LA-4126; N 70-12094 (Mar.).

Subbotin, V. I., Measurement of the velocity and temperature of a liquid metal coolant, Argonne, National Lab., I11. At. Energ. USSR (Mascan) 25, No. 2, 150, ANL-Trans-690; N 69-17152.

Suckewer, S., et a1, Study of various methods of determining the plasma temperature in an MHDgenerator duct, Vienna, International Atomic Energy Agency, Proc., 2179; A69-28023.

Van Geet, A. L., Calibration of the methanol and glycol nuclear magnetic resonance thermometers with a static thermistor probe, Anal. Chem. 40,2227 , (Dec.).

\section{9}

Czerniewski, M., and L. Labno, Fue1 temperature transients in EWA-2 and EWA-4 cores at flow failure and ramp reactivity addition tests, Inst. of Nuclear Research, Warsaw, Poland, Rept. No. INR-1090; N70-19368.

Dale, W. B., et al, Instrumentation of nuclear reactors, British patent no. 1, 139,722; NSA-23: 11246 (Jan. 15).

Droege, J. W., et al, Refractory-metal thermocouples in nuclear and high-temperature applications, Battelle Memorial Inst., Columbus, Ohio, Contract W-7405-ENG-92; BMI-X-10246; N 69-22926.

Hesse, L., Miniature sheathed thermocouples in reactor engineering, Kerntechnik 11, 281, NSA$23: 38381$ (May).

Jude, P. V. W., Irradiation tests of piezoelectric quartz crystal thermometers, Boeing Co., Huntsville, Ala. (Launch systems branch) Rept. No. T5-6441; AD-865272L (Dec.).

Kuhlman, W., and W. Baxter, A 1000 -hour, $2300^{\circ} \mathrm{C}$ thermocouples test, 15th Annual Meeting of the American Nuclear Society, Seattle, Wash, CONF690609; NSA-23: 35562, Trans. Am. Nuc1. Soc. 12, 319 (June).

Leonard, J. H., Conditions contributing to radiation-induced thermocouple decalibration, Univ. Cincinnati, Ohio, Nuc1. App1.6, No. 3, 202, (March).

Lynnworth, L. C., et a1, U1trasonic thermometry for nuclear reactor, IEEE Trans. Nuc1. Sci. Ns-16, 184; A 69-19186 (Feb.).

McGrath, T. J., and D. E. Williams, Compatibility study of common thermocouple materials with FHUST Zircaloy-clad heaters, Idaho Nuclear Corp., Idaho Fa11s, Rept. No. IN-1307; N 70-19357. 


\section{Nuclear Applications}

Rada, G. , H. Groening, and W. Parker, Use of chemical temperature indicators in high-level radiation fields, 15th Annual Meeting of the American Nuclear Society, Seattle, Wash., Trans. Am. Nuc1. Soc. 12, 309, CONF-690609; NSA-23: 35562 (June).

Reavis, J. G., J. T. Buchen, and J. A. Leary, Differential thermal analysis apparatus for observation of refractory plutonium compounds, Los A1amos Scientific Lab., New Mexico, LA-4103; N $69-41400$.

Saldago, P. G., B. J. Thamer, and R. L. Rudman, Grooved melt wires for temperature measurement of reactor fuel, Los Alamos Scientific Lab., New Mexico Rept. No. LA-4321; N70-26908 (Aug.).

Sandefur, N. L., Reliability of high-temperature thermocouples in irradiation capsules, Gulf General Atomic, San Diego, Calif. Symposium on Development of Irradiation Testing Technology, Sandusky, Ohio, CONF-690910-7; Report No. GA-9653; N70-22767 (Sept. 18).

Smith, A., Differential thermocouple and its errors in a reactor environment, United Kingdom Atomic Energy Authority, Harwe11, Eng. AERE-R. 5921; N69-41245 (Apr.).

Tarassenko, S., Temperature measurements inside nuclear reactor cores, Commissariat L'Energie Atomique, Saclay, France, CEA-R-3916; N70-12930 (Nov.).

Van Geet, A. L., Temperature measurement in nuclear magnetic resonance with a spinning thermistor, Rev. Sci. Instr. 40, No. 1, 177 (Jan.).

Yates, M. K., and J. W. Holland, Diagnostic and thermometry methods for in-pile thermionic converter testing, Gulf General Atomic, San Diego, Calif., GA-8634; Contract AT 04-3-167; N69-260 27 (Jan.). 


\section{Associated Equipment and Testing Procedure}

1964

Greenblatt, S., Controller uses transistor as a temperature sensor, Mass. Inst. of Tech., Cambridge, Research Lab. of Electronics, NIH-MH04737-04; Contract DA-36-039-AMC-03200(E); NASACR-58727.

Mills, B. G., and R. G. Griffin, Temperature verification system, Rocky Flats Plant, Dow Chemical Co., Denver, Colo., CAPE-1186 (11 drawings), avail. CFSTI (July 9).

Thomas, C. B., and S. D. Probert, Improved thermal insulation using thermoelectric phenomena, Brit. J. App1. Phys. 15, No. 9, 1120.

Williams, A. J., and A. C. Mergner, Self balancing bridge with range and precision adequate for a platinum thermometer, Proc. Instr. Soc. Am. Ann. Conf. 19, 12.1.4.64.

\section{5}

Astakhov, O. P., and V. V. Lobankov, Method for measuring the thermoelectric characteristics of semiconductors in the solid and liquid phases at high temperatures, Meas. Tech. (USSR) No. 9, 820 (Sept.).

Danishevskii, S. K., and N. I. Smirnova, Furnaces for calibrating metal thermscouples up to 2000 $2500^{\circ} \mathrm{C}$, Meas. Tech. (USSR) No. 12, 1126 (Dec.).

Donskoi, A. V., and I. Sh. Lutsker, Construction of batteries of thermocouples for measuring temperature differences in liquids, Instr. Construct. No. 4, 25 (Apr.).

Gehrung, E. E., Qualification test of thermocouple power supply and bridge circuit models, Lockheed Missiles and space Co., Sunnyvale, Calif., Rept. No. LMSC-A-621436; AD-486 146L (May 14).

Golub, L. M., et al, New "blackbody" radiation for the temperature range $1500-3000^{\circ} \mathrm{C}$, Meas. Tech. (USSR) No. 11, 1083 (Nov.).

Kimura, M. , and N. Yamanaka, Spectroscopic measurement of flame temperature in magnetohydrodynamic generator, Denki Shikensho Iho 29, 313 (April).

Parker, R., Method of determining the response of temperature sensors to a rapid temperature rise, Rev. Sci. Instr. 36, No. 12, 1880 (Dec.).

Schrenker, H., Automatic electronic compensators in immersion thermocouple systems, Arch. Tech. Messen No. 358 , R141 (Nov.).

Schroder, K., and N. P. Baum, Adjustable dewar systems for Seebeck coefficient measurements from 77 to $600^{\circ} \mathrm{K}$, Rev. Sci. Instr. 36, No. 11, 1648 (Nov.).
Shimanskii, Yu. N., et al, Measurements of temperature in a high-frequency magnetic field, Meas. Tech. (USSR) No. 10, 971 (Oct.).

Stair, R., et al, Factors affecting the sensitivity and spectral response of thermoelectric (radiometric) detectors, App1. Optics. 4, 703.

Studennikov, Yu. A., and G. E. Erkovich, Substitute apparatus for the thermocouple $W$-Re $5 / 20$, Zavodsk. Lab. 31, No. 3, 390 .

Suchomel, D., and J. Novotna, Protective ceramic coating of thermocouples for high temperatures, Czech. 123,082 (c1. H olm, G OIK), May 15, appl. (Oct. 11).

Tallman, C. R., Analytical model for study of thermocouple error attributed to electrical conduction in insulation, Los Alamos Scientific Lab., Univ. of California, LA-DC-7055; NSA 202103 .

Zaks, L. M., et al, Thermistor bridge with an automatic digital display and zero correction, Meas. Tech. (USSR) No. 9, 848 (Sept.).

\section{6}

Adbry, P. R., Cryostat temperature measurement from $0.1^{\circ} \mathrm{K}$ to $20^{\circ} \mathrm{K}$ using a Wien bridge oscillator, Elec. Eng. 38, 778 (Dec.).

Alexander, W. E., Design and construction of a cryogenic liquid level temperature transducer, Air Force Flight Dynamics Lab., Wright-Patterson AFB, Ohio, Report No. AFFDL-TR-66-179; Proj: AF1347; Task: 134702; AD-648 981 (Oct.).

Banks, R. E., An automatic system for the measurment of sound velocity, temperature, and depth in the ocean, Naval Research Establishment, Dartmouth, (Nova Scotia) Report No. 66/9; AD805093 (Oct.).

Beakley, W. R., An instrument for multiplexing and calibrating 32 channels of temperature measurement in association with Weedram, Rocket Propulsion Establishment, Westcott, Eng. Tech. Report, Report No. REP-TR-66/5; AD-813 287 (Apr.).

Beerman, H. P., Thermoelectric cooling of infrared detectors, Am. Ceram. Soc. Bul1. 45, No. 1, 2 (Jan.).

Benedict, R. P., Efficiencies in thermocouple circuts, Electro-Technol. 77, 52 (Feb.).

Bernard, J. L., and G. Cudey, An apparatus for differential thermometry with thermistors, Bull. Soc. Chim. France No. 1, 350.

Chandon, H. C., and A. R. Larson, Device for measuring the temperature of liquid and gaseous hydrogen, Sci. Tech. Aerospace Rept. 4, No. 18, 3548, NASA-CR-764 17; N66-31701.

Cope, G. W., Many thermocouples - one reference, ISA J. 13 , No. 10,73 (Oct.). 
Danishevskii, S. K., and N. I. Smirnova, Furnaces for calibrating metal thermocouples up to 2000 $2500^{\circ} \mathrm{C}$, Meas. Tech. (USSR) No. 12, 1126 (July).

Diamond, J. M., A Mueller bridge set for cryogenic temperature measurements, J. Sci. Instr. 43, No. 8, 576 (Aug.).

Dromgoole, W. V., Air temperature digitizer: range $0^{\circ} \mathrm{F}-99^{\circ} \mathrm{F}$, Elec. Eng. 38, 805 (Dec.).

Evans, J. P., Improved resistance thermometer bridge, Instr. Control Systems 39, No. 5, 109 (May).

Filippov, O. K., and E. V. Ukhanov, Hightemperature blackbody for the far infrared part of the spectrum, Pribory $i$ Tekhn. Eksperim. No. 6, 144 (Nov. - Dec.).

Firing, J: A., In-cone instrumentation developed for full testing at HBWR, Institute for Atomenergi, Halden, Norway, NSA 20, No. 19 (Oct. 15).

Goard, P. R. C., Application of hemispherical surface pyrometers to the measurement of the

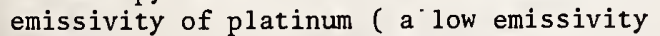
material), J. Sci. Instr. 43, 256 (April).

Goldsmid, H. J., A dc transformer based on thermoelectric effects, J. Sci. Instr. 43, No. 10,774 (Oct.).

Golub, L. M., et al, Method for extending the scale of a radiation pyrometer to the hightemperature range, Meas. Tech. (USSR) No. 10, 963 (Apr.).

Golub, L. M., et al, New "blackbody" radiation for the temperature range of $1500-3000^{\circ} \mathrm{C}$, Meas. Tech. (USSR) No. 11, 1083 (Apr.).

Golyuk, N. G., Attachment to contact thermometer, Ind. Lab. (USSR) 32, No. 10, 1587 (Oct.).

Harris, H. E., Bridge temperature recorders, Instr. Control Systems 39 , No. 12,99 (Dec.).

Ha1th-Larsen, E., and E. Joranger, A radiation shield for resistance thermometers and thermocouples, AD-809 205L (July).

Johnston, J. S., and J. Charman, Precision resistance ratio bridge, Instr. Control Systems 39, No. 5, 117 (May).

Kirch, W., and J. Soehlemann, Arrangement for the measurement of potentials of several thermoelements attached to an electrical-conducting body, Ger. Patent No. 1,225,893 (Sept. 29).

Kogan, A. V., E. A. Kolenko, and E. S. Nechai, Low-temperature blackbody based on the thermoelectric refrigerator, Pribory i Tekhn. Eksperim. No. 6, 178 (Nov. - Dec.).

Lindsay, J. D. G., Transistorized liquid helium temperature regulator, Rev. Sci. Instr. 37, 1192 (Sept.).
L'vov, S. N., P. I. Mal'ko, and V. F. Nemchenko, Assembly for determining the temperature dependence of the thermal conductivity coefficient, thermal emf, and specific electrical resistance of cermet materials, Poroshkovaya Met., Akad. Nauk Ukr. SSR (Kiev) 6, No. 9, 89 (June).

Mallard, H., The detection of a thermocouple failure by the injection of an H.F. signal, Safriean Mech. Engr. 16, No. 2, 25 (Sept.)

Mazur, S. P., Device for multiple-point measurement of temperature, Foreign Technology Div., Wright-Patterson AFB, Ohio, Report No. FTD-TT65-1937; AD-638 872 (June).

Metzner, D., A digital temperature referencepoint regulator, Elektronika 15, 209 (July) .

Mingus, M. V., Product-improvement test of Jetcal tester, (Transistorized), Army Aviation Test Board, Fort Rucker, Ala., Final report, Proj: USATECOM-4-6-5011-01; AD-804 864L (Dec. 24).

Neel, L. W., Water-glycol radiatior flow valve sensor, P/N 401-07700, North American Aviation Inc., Space and Information Systems Div., Downey, Calif., Development test report, AD-807 136L (Feb.).

Nelson, D. D., and J. D. Burns, Potentiometric resistance measurement, Instr. Control Systems 39, 127 (May).

Osborn, J. R., and D. W. Craft, Emf pickup, Instr. Control Systems 39, 157 (May).

Petrov, V. I., and A. P. Kobarenkov, Hightemperature hermetic lead for thermocouples, Prib. Tekh. Eks. No. 4, 251 (July - Aug.).

Rutman, D. S., L. V. Vinogradova, and T. S. Makarova, High-temperature protective ceramics for thermocouples, Vysokoogneupor. Mater., Sk. Statei 72,

Scheppner, E. E., Instrumentation equipment specification, transducer, temperature, platinum resistance type, for corrosive fluids, Rocketdyne- Canoga Park, Calif., Final Spec. Report No. SPEC-IES-6-002; AD-831 085L (Mar.).

Scheppner, E. E., A small liquid helium cryostat for calibration of resistance thermometers, Rocketdyne, Canoga Park, Calif., Report No. TR66-5; AD-806 712L (Feb.).

Seidel, J., Thermocouple insulator development during contract year 1966, Astronuel. Lab., Westinghouse Elec. Corp., Pittsburgh, Pa.: Nuc1. Sci Abstr. 22, No. 14; NSA-22-28916.

Shortland, M., and D. J. Standley, Thermocouple switch works inside slab furnace, Instr. Pract. 20, No. 1, 49 (Jan.).

Stone, O. C., and D. B. Schneider, An automatic calibration system for cryogenic temperatures, Proc. Instr. Soc. Am. Ann. Conf. 21, 1966 Part 1, Paper 12.11-2-66. 
Trefny, F., A new laboratory apparatus for measurement of temperature differences and its application, Brennst off-Chem. 47, No. 8, 235.

Wagner, R. E., Dynamic study of temperature transducer by use of an optical method, ASME, Paper 66-WA/AUT-11; A67-15417.

Williams, A. J., and G. C. Mergner, A self-balancing bridge with range and precision adequate for a platinum thermometer, IEEE Trans. Instr. Meas. IM-15, 121 (Sept.).

Yanulis, V. V., and I. S. Mayauskas, Determination of spectral coefficient of reflection, emittance, and true temperature of opaque solids at high temperatures in reflector furnaces, Joint Publ. Research Service, Heliotechnol. No. 5, 26 (Apr. 4) Wash. D. C.; N67-28167.

Bridge accepts many temperature probes, Electronics 39, 176 (May 30).

Precision pyrometer, CMB-3, Los Alamos Scientific Lab., (Univ. of California), New Mexico, CAPE1331; NSA 20, No. 14, 25363 (July 31).

Process instrumentation development, Oak Ridge Natl. Lab., Tennessee, ORNL-3875; NSA 20, No. 22, 41233 (Nov. 30).

\section{7}

Angus, D. E., A multi-purpose digital thermometer, Australian J. Instr. Control 23, No. 4, 118 (Nov.).

Bettex, $W$, et al, Electronic reference temperature device, Microtecnic 21, No. 5, 494 (Oct.).

Brown, D. W., Selection and use of pyrometer sheaths Inst. Metals J. $\underline{95}, 12$.

Dittrich, R. T., and M. P. Lynch, Bimetal sensor for averaging temperature measurement of nonuniform temperature profiles, NASA, Lewis Research Center, Cleveland, Ohio, NASA-TN-D-4242; N68-159 36 (Nov.).

Drummeter, L. F., and J. A. Sanderson, Improved responsivity of gas-filled thermopiles, Appl. Opt. 6, No. 12, 2196 (Dec.).

Fryer, T. B., C. M. Winget, and J. M. Pope, An implantable multi-channel temperature transmitter, NASA-Ames. Research Center, Moffett Field, Calif., NASA-TM-X61199; N68-34345.

Gardner, J. E., J. S. Riney, and W. H. Wade, Crystal-thermometer calorimeter, Rev. Sci. Instr. 38, No. 5, 652 (May).

Gazamiadou, A., and R. Goutti, Calibration of very low temperature measurement gages - description of cryostat, Entropie 43 (Jan. - Feb.).

Geyer, E. H., and W. Pieper, Blackbody radiators for high temperatures, Feingerae Etechnik. 16, No. 4, 153 (Apr.).

:a11, J. A., A design of furnace for very uniform temperatures, J. Sci. Instr. 44, 257 (Apri1).
Hi11, J. J., Platinum resistance thermometry using an ac inductive radio bridge, Proc. Instr. Soc. Am. An. Conf. 22nd, 22, Part one, Paper No. M94-MEST IND- 67.

Jury, S. H., Mechanically refrigerated ice bath, Instr. Control Systems 40, 118 (May).

K1yarovskaya, T. G., and Ya. V. Vasil'ev, Use of the MOD-54 bridge for measuring temperature with a resistance thermometer, Zh. Fiz. Khim. 41, No. 4, 936 .

Kolesnikov, A. G., Instruments for measuring turbulent pulsations of current velocity and temperature at great depths, Trans, of Akad. Nauk? (URSR) Kiev, Morskyi Hydrofizychny; Instytut. Trudy 36, 15 (1966) AD-661 752; N68-13644.

Kuzyk, W., Linear cryogenic compensation, Instrum. Technol. 14, No. 5, 70 (May).

Maher, F. J., The multivibrator bridge for temperature measurement, J. Sci. Instr. 44, No. 7, 531 (July).

Murray, T. P., Polaradiometer-a new instrument for temperature measurement, Rev. Sci. Instr. 38, No. 6, 791 ' (June).

Muth, S., Reference junctions, Intr. Control Systems $\underline{40}$, No. 5, 133 (May).

Novitskii, L. A., and N. N. Ergardt, New instruments for high-temperature research, Teplofiz Vyz. Temp. (USSR) 5, No. 6, 1075 (Nov.).

Oshanin, V. M., Sounding thermometer with induction depth sensor, Joint Publications Research, Service, Washington, D. C., Methods and Instr. for Marine Research, Joint Publication Research Service (JPRS 39881); TT-67-30-529; N67-22368 (Feb. 13).

Petrov, V. I., and A. P. Kobarenkov, Hightemperature hermetic lead for thermocouples, Prib. Tekh. Eks. (USSR) No. 4, 251 (July - Aug.)

Quin, T. J., and C. R. Barber, A lamp as a reproducible source of near blackbody radiation precise pryometry up to $2700^{\circ} \mathrm{C}$, Metrologia 3 , No. 1,19 (Jan.).

Quin, T. J., The calibration of the emissivity of cylindrical cavities giving near blackbody radiation, Brit. J. App1. Phys. 18, No. 8, 1105 (Aug.) .

Rusin, S. P., and V. P. Ovchinnikov, Apparatus for studying the high-temperature emissivity of materials, Soviet Powder Metallurgy and Metal Ceramics, Porosh. Met. 7, 47 (Jan.).

Simbirskiy, D. F., Characteristics of the dynamic calibration of an instrument for measuring the instantaneous temperatures of gas flows, Samoletostroyeniye i Tekhn. Vozdushnogo Flota (USSR) No. 2, 59, FTD-HT-23-874-67, AD-669 271 (Aug.) . 
Smirnov, E. V., and Yu. A Kondrashov, Integral emissivity of materials in the temperature range 100 to $1100^{\circ} \mathrm{C}$, Teplofiz. Vys. Temp. (USSR) 5, No. 1,44 (Jan. - Feb.).

Stone, O. C., and D. B. Schneider, Calibrating cryogenic sensors, Instrum. Technol. 14, No. 4, 53 (Apri1).

Sutton, G. R., Evaluation of an automatic thermocouple reference junction chamber, Royal Aircraft Establishment, Farnborough, England, Technical Report No. RAE-TR-67235; AD-829 388 (Sept.).

Syrovy, K., and B. Saroun, Thermoelectrically cooled standard temperature reference cell, SNTL Tech. Dig. 9, No. 4/5, 304 (Apr. - May).

Terwilliger, H. M., A new metal freezing-point temperature standard, Leeds Northrup Tech. J. (Summer) 22 .

Toombs, D. S. Jr., Reliability and circuit analysis of thermopiles with redundant elements, IEEE Trans. Nuc1. Sci. NS-14; No. 4, 17 (Aug.) .

Williams, J. R., and J. A. Henderson, A fixed point thermocouple calibration facility, J. Sci. Instr. 44, No. 1, 78 (Jan.).

Yamada, H. Y., A high-temperature blackbody radiation source, App1. Opt. 6, 357 (Feb.).

Ambient reference for thermocouple, Electronics 40, 193 ( Jan. 23).

Insulating thermocouple wires, Englehard Industries, Inc., British Patent No. 1,088,660 (Oct. 25).

\section{8}

Anufriev, A. A., V. F. Vshola, and L. A. Novitskii, Electronic equipment for measuring the temperature of transient processes in the range 500 $2000^{\circ} \mathrm{K}$, Meas. Tech. (USSR) No. 11,1477 (Nov.).

Babbe, E. L., Zapper: a device for repairing opencircuited thermocouples U.S. At. Energy, Comn., AEC Memo-12710; CFSTI.

Baleshta, T. M., and D. W. Carson, Apparatus for measuring thermo-electric powers of semiconductors from 77 to $600^{\circ} \mathrm{K}$, Mines Branch, Dept. of Energy, Mines and Resources, Ottawa, Canada, J. Sci. Instr. 1 , Series 2 (Nov.).

Bigeleisen, J. A., et a1, Cryostat for thermal measurements between $2-300^{\circ} \mathrm{K}$, Rev. Sci. Instr. 39, No. 3 (Mar.).

Colarusso, V. G., and M. A. Semon, Measurement of calibration standards for thermometry, Fisher Scientific Co., Fair Lawn, New Jersey, Anal. Chem. 40, No. 10, 1521 (Aug.).

Conrad, G., Linearization of thermocouple voltage, Rev. Sci. Instr. 39, No. 11, 1682 (Nov.).
Daneman, H. L., and G. C. Mergner, Method of applying a modern potentiometer for resistance thermometry, Leeds and Northrup Co., North Waes. Pa., Rev. Opt. (France) 39, No. 10, 1498.

Dembinski, K., M. Faucher, and A. Anthony, Hightemperature furnace $\left(2400^{\circ} \mathrm{K}\right)$ in an oxidizing atmosphere, Lab. Exchanges Therm., C. N. R. S., Bellevue-Meudon, France, C. R. Acad. Sci., Paris Series C 267, No. 19, 1185.

Duda, C. R., Liquid helium cryostat for resistance thermometer calibration, Rev. Sci. Instr. 39, 1484 (Oct.).

Geyer, E. H., Measurement of the emissivity factor of a cavity radiator for pyrometric process, Feingeraete-Technik 17, No. 1, 9 (Jan.).

Geyer, E. H., Determination of the emissivity of a cavity radiator suitable for pyrometry, Feing Tech. 17, No. 1, 9 (Jan.).

Gol'tsman, B. M., and V. Sh. Sarkisyan, Rapid determination of the thermal conductivity of thermoelectric materials, Institute of Semiconductors, Acad. of Sciences of the USSR, Leningrad, Prib. Tekh. Eks. No. 1, 200 (Jan. - Feb.).

Hil1, J. J., Platinum-resistance thermometry using an ac inductive ratio bridge, ISA Trans. 70, No. 2,101 .

Imperiali, F., and E. Paolucci, AM amplifier for thermocouples, Rept. No. RT/EL/68/2; N68-35721.

Jefferies, E. B., and B. T. Remnant, The design of a mechanical switch for producing short duration high energy electrical pulses, Royal Aircraft Establishment, Farnborough, England, Rept. No. REA-TR-68069; AD-840627; N69-11655.

Kaufman, A. B., Temperature bridge nonlinearities, Instr. Control Systems, 4, No. 5, 93 (May).

Kerr, S. G., An automatic multi-point temperature recorder, Aeronautical Research Labs., Melbourne (Australia); ARL/ME-296; N69-10290 (May).

Knight, B. A., A mercury vaporizer temperature controller for an ion engine, Royal Aircraft Establishment, Farnborough, England, RAE-TR68292; N70-11189 (Dec.).

Krivonosov, A. I., Temperature-sensing element, Pribo. Tekh. Eks. No. 1, 230 (Jan. - Feb.).

Kuehn, L. A., Evaluation of a direct reading instrument for measuring the wet-globe temperature index, Defense Research Establishment Toronto, Dawnsview, Ontario, Defense Research Board, DRET-692; N70-13656 (Sept.).

Lazarev, B. G., Yu. Ya. Milenkov, and K. G. Breslavets, Temperatures of 14 to $6^{\circ} \mathrm{K}$ produced in solid hydrogen by vapor pumping over its surface, Dokl. Akad. Nauk. (SSSR) 178, No. 1, 74 . 
Logvinenko, S. P., and Yu. N. Brovkin, Sensor and temperature regulator for range $4.2-320^{\circ} \mathrm{K}$, Prib. Tekh. Eks. No. 1, 212 (Jan. - Feb.).

Malek, A., J. Strajblova, Construction of a reference junction of a thermocouple for very precise temperature measurements, Cesk. Cas. Fys. 18, No. 1, 95.

Moreau, C., A. Tomasini, and V. Volkovisky, Temperature measurement on structural parts of supersonic aircraft during simulated tests of kinetic heating, Rev. Gen. Thermique ㄱ, No. 73, 47 (Jan.).

Owston, C. N., Application of thermistors to optical pyrometry and temperature control, Dept. Materials, Co11. Aeronautics, Cranfield, Bedford, England, J. Sci. Instr. (G. B.) Series 2, 1, No. 12, 1128 (Dec.).

Pospelov, A. A., E. K. Stepaneko, and V. G. Chukhlantsev, Use of thermistors and potentiometers in the thermal analysis of water-salt systems, Ural. Politekh. Inst. im. Kirova, Sverdlovsk, (USSR) Zavod. Lab. 34, No. 11, 1415.

Redding, R. J., Advances in instrumentation, Chem. Process Eng. 49, No. 91 (Oct.).

Servos, G. H., Multipoint temperature monitoring, Instr. Control Systems 41, No. 12, 93.

Steyert, W. A., and M. D. Daybe11, Temperature control, Los. Alamos Sci. Lab., Los Alamos, New Mexico, Moessbauer Eff. Methodol, 4, 3 .

Stoch1, R. J., and R. L. DeWitt, Temperature and liquid-level sensor for liquid-hydrogen pressurization and expulsion studies, NASA-Langley, Langley Station, Va., NSAA-TN-D-4339; N68-15893 (Feb.).

Vanderborgh, N. E., and W. D. Spal1, Method for accurate measurement of small temperature differences, Anal. Chem. 40, No. 1, 256 (Jan.).

Van Outryne, E., and R. Jacobs, Modulation systems for galvanometer controlled temperature, J. Sci. Instr. (G. B.) Series 2, 1, 679 (June).

Vshola, V. F., and L. A. Novitskii, Electronic apparatus for measuring temperature in the 500 $2000^{\circ} \mathrm{K}$ range during unsteady-state processes, Izmeritel Tekhn. No. 11, 25.

Walker, E. P., Instrumentation for power transformer winding temperature-measurement, Instrum. Practice 22, No. 2, 138 (Feb.).

Wolfendale, P. C., A precise automatic ac potentiometer for low temperature resistance thermometry, Automatic Systems Lab., Ltd., Leighton Buzzard, England, J. Sci. Instr. (G. B.) Series 2,2 , No. 8, 659 (Aug.).

Thermocouple data digitized, Electronics 41, 186 (Sept.).

Akkerman, O. S., Thermocouple holder for temperature measurements in variable temperature N. M. $R$. experiments, Constancy of the variable temperature controller, Vrije Univ., Amsterdam, Netherlands, Chem. Ind. (London) No. 38, 1340.

Blume, H. C., Error analysis of input-noisetemperature measurements of low-noise amplifiers, NASA Langley Research Center, Langley Station, Va., NASA-TN-D-4997; N69-16162 (Jan.).

Daneman, H. L., Cryogenic temperature sensor calibration with automatic data readout, ISA Trans. 8, No. 2, 151 .

Eischen, J., A fast low-level commutators, Rech Aerosp, 69; A69-24758 (Jan.).

Fintinaru, N., and J. Wetzler, Checking a thermoelectric temperature-measuring instrument, Inst. Messwesen, Timisoara, Rom., Feingeraetetechnik 18, No. 4, 163 .

Fleishner, P. L., J. R. Hadshov, and K. H. Styhr, Beryllium oxide insulators in hyper-enviromental applications, Presented at Spring meeting of SAE (Apr. 21 - 24, 1969) National Beryllia Co., Paper No. 690427 (April).

Freymouth, P., Compensation for the thermal lag of a thin wire resistance thermometer by means of a constant temperature hot-wire anemometer, J. Sci. Instr. 2, No. 2, 1001 (Nov.).

Gaylord, W., and V. Carter, Fluerics 27, Flueric temperature-sensing oscillator design, Harry Diamond Labs., Washington, D. C. Rept. No. HDLTR-1428; AD-689 444 (Apri1).

Gebel, R. K., The normalized cumulative blackbody functions, their applications in thermal radiation calculations and related subjects, Aerospace Research Labs., Office of Aerospace Research Wright-Patterson AFB, Ohio ARL-69-0004 (Jan.).

Goldwater, F. J., Multipoint temperature measurement, Instr. Control Systems, 42, No. 5, 81 (May).

Goosey, M. H., et al, High speed temperature monitor, U. S. Patent No. 3,459,92.5; NSA-23:40461 (Aug. 5).

Hennephof, J., G. Hockstra, and J. Van Overbeeke, Thermostat for resistivity measurements at temperatures from 4 up to $350^{\circ} \mathrm{K}$, Univ. Groningen, Neth., J. Sci. Instr. 2, No. 1, 96.

Jackson, R. C., Integral calibrations for thermocouples, Instrum. Tech. 16, No. 11, 43 (Nov.).

Jacobs, J. D., Measurement of temperature associated with bubbles in subcooled pool boiling ASME Trans. Series C-J Heat Transfer, 91, 123, A69-27779 (Feb.). 

Jeffries, E. B., and B. T. Remnant, The design of
a mechanical device for producing short duration high energy electrical pulses, Royal Aircraft Establishment, Farnborough, England, Rept. No. RAE-TR-68069; N69-11655.

Kamenetskii, A. B., and N. V. Gladkaya, Developing new types of thermocouple jackets with a higher resistance to bending stresses, Meas. Tech. (USSR) 11,1536 (Nov.).

Kerr, S. G., An automatic multipoint temperature recorder, Aeronaut. Res. Laboratory, Melbourne, Australia; Rept. No. ARL/ME-296; N69-10290.

Kiselev, Yu. I., and G. S. Bondarev, Using a multipoint potentiometer for simultaneously recording visocity and temperature, Ind. Lab. (USSR) 35, No. 11,1717 (Nov.).

Makerenko, I. N., et al, Equipment for measuring the thermal properties of metals at high temperature, Ind. Lab. (USSR) 35, No. 9, 1361 (Sept.).

Menzel, E., and J. Stahlknecht, Optical and thermoelectric thermometry of small, spherical, metal crystals, Tech. Univ. Braunschweign, Brunswick, Germany, Z. Angew. Phys. 26, No. 3, 216.

Moffat, R. J., Gas-temperature measurement: direct design of radiation shielding, ISA Trans. 8, No. 2, 91 .

Remizov, Yu. S., and G. V. Kim, Device for regulating and continuously recording temperature in the presence of electromagnetic interference, Meas. Tech. (USSR) 1, 146 (Jan.).

Rixom, P, J., and W. G. Townsend, The silicon integrating light detector applied to optical pyrometry, Div. Electrical Engineering, Univ. Coll. Swansea, Wales, J. Sci. Instr. (G. B.) Series 2, 2, No. 2, 153 (Feb.).

Roberts, M. L., Potentiometric bridge for resistance thermometry, ISA Trans. 8, No. 2, 157.

Rowse, H. R., and J. L. Monteith, A fifty-channel digital recorder for thermocouple pyschrometers, J. Sci. Instr. 2, No. 2, 397 (May).

Sautter, H., Self-balancing Wheatstone bridge for low temperature measurements, Univ. Stuttgart, W. Germany, Z. Angew. Phys. (Germany) 26, No. 5, 362.

Scheibe, W., et al, Deep sea reversing thermometer, its operation and testing, Natl. Lending Library for Science \& Technology, Boston Spa England, Translated from German Report No. PTB-4-68; N70-21175 (Nov, 21).

Schulte, E. H., E. O. Puronen, and W. P. Dixon, Calibration apparatus for surface thermocouples, International Congress on Instrumentation in Aerospace Simulation Facilities, 3rd, Poly. Inst. of Brooklyn, Farmingdale, New York; A6935725 (May $5-8$ ).
Stafsudd, 0., and N. Stevens, Thermopile performance in the far infrared, Appl. Opt. 7, 2320 (June)

Sutton, G. R., An extended zone system for multiple thermocouple installations, Royal Aircraft Establishment, Farnborough, England, Rept. No. RAE-TR-69029; AD-856997 (Feb.).

Wal, C. W., and L. C. Struik, A direct-reading bridge for a platinum resistance thermometer, Central Lab. TNO, Delft, Netherlands, J. Sci Instr. (G. B.) Series 2, 2, No. 2, 143 (Feb.).

Wolfendale, P. C., A precise automatic ac potentiometer for low temperature resistance thermometry, J. Sci. Instr. 2, 659 (Aug.).

Zarcades, P. A., and P. Haas, Digital thermometry, Instr. Control Systems 42, No. 8, 102 (Aug.).

Model A-710 laboratory digitizer, National Oceanographic Instrumentation Center, Washington, D. C., Report No. IFS-70002; AD-873444L (July). 
Byard, P. L., and R. E. Ro11, Temperature measurement in shock heated gases, Ohio State Univ., Research Foundation, Columbus, Ohio, AFCRL66-334; AD-632840 (Dec.).

Clayton, W. H., B. J. Eckelkamp, and J. H. Machetta, A wet-dry-bulb temperature measuring system for micrometeorological application, Final Report, Texas A. and M. Univ., College Station, Texas, TAMU Ref-64-14F; Contracts AF19 628 2411; Projs. 7655, 340, Task: 765501; AD-610107 (Sept. 24).

Cookson, R. A., P. G. Dunham, and J. K. Kilham, Noncatalytic coatings for thermocouples, Combust. Flame 8 , No. $2,168$.

Flahaut, J., Modern high temperature development, Diagrammes No. 91,5 .

Hurst, N. J., Effect on thermocouple size and installation on temperature readings, Army Missle command, Redstone Arsenal, Alabama, Report No. RS-TM-64-1; Proj. 1A013001A039; AD-612493.

Keyte, F. K., On the formulas for correcting reversing thermometers, Woods Hole Oceanographic Institution, Mass., Grant NSF GP821 Rept. No. PB-166-070.

Moen, W. K., Measurement system, temperature, Space and Information Systems Div. North American Aviation Inc, Downey, California, Report No. MC431-0022E; AD-484944L (Nov. 12).

Yaffe, B., Jet exhaust measurements, Goddard Space Flight Center, Greenbelt, Md., Goddard Summer Workshop Program; N66-14115.

\section{5}

Asamato, R. R., and P. E. Novak, A survey for a high temperature sensor for Sefor., General Electric Co., San Jose, California, GEAP-4903; NSA 20-3473.

Belcher, P. R., and R. W. Wilson, Templugsversatile miniature thermometers and thermal gradient recorders, Proc. 1st. Internat. Conf., Thermal Analysis, Aberdeen (London) Macmillan, 35 .

Bellezza, M., Welding fine wires, British patent No. 1,152,717; NSA-23:29287 (May 21).

Birr, H., Temperature measurement, Ver. dt. Ing. 107, No. 30,1471 (Oct.).

Boyarskii, L. A., Errors in measuring color temperatures, Meas. Tech. (USSR) No. 9, 879 (Sept.).

Cheesewright, R., Technique for stripping sma11 diameter metal sheathed thermocouple wire, J. Sci. Instr. 42, 815 (Nov.).

de Klerk, J., Elasti constants and debye temperature of TiC using a new-ultrasonic coherent pulse/cw technique, Rev. Sci. Instr. 36, 1540 (Nov.).
Ergardt, H. H. , Some thermoelectric properties of platinorhodium alloys, High Temp. 3, No. 5, 643, (Sept. - Oct.).

Gordov, A. N., Peculiarities of the measurements of temperature under conditions of alternating heat emissions, Foreign Tech. Div., Air Force Systems Command, Wright-Patterson AFB, Ohio, FTD-TT-64-1076; TT 65-62287; AD-615 431 (Apr. 5).

Haase, D. J., and H. Steinfink, Thermoelectric and electrical measurements in the Er-Se system, J. Appl. Phys. 36, 3490 (Nov.).

Hendricks, J. W., and D. L. McElroy, Hightemperature high vacuum thermocouple drift tests, Report No. ORNL-P-1069, NSA 19, No. 11, NSA No. 19-20278; Avail CFSTI (June $\overline{15}$ ).

Hiorns, F. J., Temperature measurement, B.C.U.R.A. Gaz. No. 54,5 .

Jasicki, Z., and A. Handke, Certain problems concerning measurement of temperature, Pomiary, Automat. Kont. No. 8, 340 (Aug.).

Ke11y, A. J., N. M. Nerheim, and J. A. Gardner, Electron density and temperature measurements in the exhaust of MPD source, J.P.L. (Cal. Tech.) Pasadena, California, Rept. No. NASA-CR67060; JPL-TR-32-7961; CFSTI; N65-34399 (Sept. 15) .

Kuhlman, W. C., Thermocouple research at GE-NMPO, General Electric Co., Cincinnati, Ohio, CONF650204-9; GE-TM-65-2-15; NSA 20-20185.

Lasissus, J., Thermometry and pyrometry, Mes. Regul. Automat. 30, No. 10, 82 (Oct.).

Larson, M. B., Time-temperature characteristics of thin-skinned models as affected by thermocouple variables, First Semiannual Report, NASACR-68315; N66-13008 (Oct.).

Lieneweg, F., Temperature measurement; radiation pyrometer and thermometer testing, Part 2, Arch. Tech. Messen No. 359, 285 (Dec.).

Marlatt, W. E., The measurement of the surface temperature of the earth, Technical Paper No. 64, Colorado State Univ., Fort Collins, Dept. of Atmospheric Science, NASA-CR-62117; N6521425 .

Maykuth, D. J., R. H. Ernst, and H. R. Ogden, The thermoelectric properties of tantalum alloys, Trans. Meta11. Soc. 233, No. 6, 1196 (June) .

Miksch, E. S., Equilibration of the ice-water temperature standard, Rev. Sci. Instr. 36, 797, (June).

Moser, H., Gas thermometry at elevated temperatures, Metrologia 1, 68 (Apri1).

Mott, G. D., Fatigue studies of bare bulb thermometers, Naval Boiler and Turbine Lab., Philadelphia, Pa., NBTL-A-436; AD-476238L. 
Naumann, A., and H. Poppinger, Transducers for Gas Dynamics: Proceedings of the Fifth Interprocess control, Siemens-Z. 39 , No. 9, 965.

national Symposium, Oxford University, Oxford, England, 2, A67-28160 (July 4 - 8).

Nepomnyashchiy, The measurement of air temperature in flight, Army Foreign Service and Tech. Center, Washington, D.C., Report No. FSTC-381-T65-561; $\mathrm{AD}-474807$.

Oleimik, B. N., The measurement of heat constants, Tr. Inst. Gos. Kom. Standartov, Mer i Izmerit. Priborov (SSSR) No. 76, 123.

Perkins, J. M., and R. J. Twiford, Space vehicle reentry sensor, Avail. Commissioner of Patents, Washington, D.D., No. 3,169, 724 .

Pinchevskii, A. D., Transfer functions for commercial thermoelements, Meas. Tech. (USSR) No. 5, 416 (Nov.).

Polak, J., Electrical resistivity and thermoelectric power of stacking faults in gold, Phys. Status Solidi 11, No. 2, 673 .

Reap, R. M., and T. Fujital, Death valley temperature analysis utilizing Nimbus I infrared data and ground-based measurements, Chicago Univ., IIf Dept. of Geophysical Sciences, NASA-CR-67228; SMRP-RP-45; N65-35106 (Aug.).

Sparks, L. L., and R. L. Powell, Available lowtemperature thermocouple information and services, Nat. Bur. of Standards, Boulder, Colorado, NBS-8750 No. 11 , NASA-CR-63149; N6525244 (Feb. 15).

Solukhin, R. I., and S. Zh. Toktomysev, Temperature measurement behind the detonation front in a gas, Zh. Prik1. Mekh. Tekh. Fiz. 124.

Stransky, K., Method of dimensional analysis for measuring paving temperatures with an immersion pyrometer, Slevarenstvi 13, No. 12, 460.

Vedernikov, M. V., I. A. Markova, and G. N. Meshkova, Electrical resistance and thermoelectric power of $\mathrm{La}-\mathrm{Ce}, \mathrm{La}-\mathrm{Pr}$ and $\mathrm{Pr}-\mathrm{Nd}$ alloys, Sov. Phys.-Solid State 7 , No. 3, 766 (Sept.).

Volenik, K., Contribution to the thermoelectric properties of Fe-Si alloys, Phys. Status Solidi 12, No. 1, K25.

Williams, R. J., and E. H. Kaiura, Time constant study of some commercial temperature sensors at cryogenic temperatures, Boeing Co., Seattle, Washington, Report No. D2-23831-1; AD-485191L.

Temperature measuring systems, Instr. Control Eng. 46 (October).

High temperature thermometry, 35 Papers presented at a seminar at AEC Headquarters, Washington, D.C., WASH-1067; NSA21-346 (Feburary).

\section{6}

Atassi, H., and E. A. Brun, Heat transfer from wires in a rarefied low speed flow, Rarefied

Bayley, F. J., and A. B. Turner, Bibliography of heat-transfer instrumentation, Aeronautical Research Council (G. B.) ARC-REM-3512; AD-834124; N68-37994 (Nov.).

Belevtsev, A. T., R. V. Koval'skii, and M. S. Yakhats, Performance of semiconductor thermoelectric devices at constant heat flux, Teplofiz. Vys. Temp. 5, No. 5, 901 (Sept. - Oct.).

Bragin, B. K., Increase in purity of platinum thermal electrode in standard platinum/rhodiumplatinum thermocouples, Tr. Inst. Gos. Kom. Stand., Mer Izmer. Prib. (SSSR) No. 84, 58.

Brodier, J., Measurement of temperatures and its practice in heat treatment, Traitement Therm. 21, 27 (May - June).

Carlsen, A. V., Evaluation of radiation compensating thermocouple temperature sensors, U.S. Govt. Research and Reports 41, No. 18, 136; $\mathrm{AD}-449874$.

Ch'in, V., An experimental investigation of the error of measurement of surface temperature, Izv. VUZ. Inst. No. 6, 165; N66-26113 (May 12).

Cini, R. A., Surface temperature of equipment estimated quickly, Chem. Eng. 73, 150 (Sept. 26).

Claggett, T. J., and R. W. Worrall, Temperature measurement and sensor selection, Instrumentation 20, No. 4, 18 .

Crook, F., and R. S. Woods, Some aspects of temperature measurement and control, Light Met. Ind. 29,59 (Jan.).

Dasgupta, S., D.C. conductivity of alumina single crystals, Brit. J. App1. Phys. 17, No. 2, 267 (Feb.).

Davidenko, N. I., and I. G. Fakidov, Cryostats for measuring electrical, thermoelectric, galvanomagnetic and thermomagnetic properties, Pribory i Tekhn. Eksperim. No. 5, 254 (Sept. Oct.).

Druzhinina, I. P., et al, Thermoelectric properties of certain metals with a high melting point, Meas. Tech. (USSR) No. 4, 505 (April).

Dummel, U., How can errors in temperature measurement be avoided?, St. Gebaud 20, 5, (Jan.).

Dutkiewicz, R. K., Time-response characteristics of temperature measuring devices, S. African Mech. Engr. 15, No. 11, 264 (June).

El Agib, A. A., et al, Effects of recovery factor on measurement of temperature of moving fluids, Thermodynamics and Fluid Mechanics Convention, Univ. of Liverpool, Liverpool (England) A6725353 (April 13 - 16). 


\section{General}

Flynn, T. M., Liquid hydrogen instrumentation, Pure and Applied Cryogenics 5, Liquid hydrogen Oxford, Symp., Publication, Div. of Pergamon Press, Ltd, 295.

Gaydon, A. G., Measurement of temperature, Brit. Coal Util. Res. Assoc. 59, 1.

Gofman, A. A., Correction of a temperature transducers dynamic error by means of a combined system of thermoelements, Meas. Tech. (USSR) No. 4, 496 (Apr.).

Golikova, 0. A., et al, Electrical conductivity and thermo-emf of niobium carbide between 20 and $2000^{\circ} \mathrm{C}$, Vys. Temp. 5, No. 6, 1001 (Nov. - Dec.).

Gordon, J. W., Feasibility study on use of crimp terminals as junctions in place of soldered or welded junctions for thermocouple wires, Naval Air Developement Center, Aero-Electronic Tech. Dept., Johnsville, Pa., Final Report No. NADCAE-6607; Task: RAE50J011/2021/F012-07 01; AD480221L (March).

Goureaux, G., and Y. Tregouet, Experimental study of the Peltier effect, Application to nickel/ metal junctions, Compt. Rend. Acad. Sci., Paris, Ser. A, B 262B, 974 .

Graevskii, M. M., Dynamic calibration of thermistors, Meas. Tech. (USSR) No. 2, 194 (Feb.).

Grandison, J. M., et al, Electrical and thermometric properties of superimposed lead-copper, Cryogenics 6, 344 (Dec.).

Hall, G. H., How to measure cryogenic temperatures, Power 110,92 (August).

Hal1, J. A., Fifty years of temperature measurement, J. Sci. Instr. 43, No. 8, 541 (Aug.).

Hare, G. E., Thermoelectricity: a status survey, United Kingdom Atomic Energy Authority, Harwell (England) AERE-M-1768; N68-22974.

Hartz, R. A., Temperature transducers, IEEE, Trans. IGA-2, No. 2, 141 (Mar. - Apr.).

Heppe11, D. H., Techniques for the measurement and control of temperature using thermal junctions, Birmingham Univ. Chem. (Eng.) 17, No. 3, 75 .

Heusinkveld, W. A., Determination of the differences between the thermodynamic and the practical temperature scale in the range 630 to $1063^{\circ} \mathrm{C}$ from radiation measurements, Metrologia 2 , No. 2, 61 (April).

Hickman, R. S., An experimental study of hypersonic rarefied flow over a $10^{\circ}$ cone, Rarefied Gas Dynamics, Proceedings of the Fifth International Symposium, Oxford University, Oxford, (Eng.) 2, 14; AD67-28160 (July 4-8).

Hinton, J. R., The measurement of temperature Part 1, Instrum. Rev. 13, No. 172, 146 (Apr.).
Hinton, J. R., The measurement of temperature, Part 2, Instrum. Rev. 13, No. 173, 193 (May).

Israel, J., A study of the thermoelectric properties of $\mathrm{Pt} / \mathrm{Ru}$ alloys, J. Nucl. Mater. 18, No. 3, 272 (Mar.).

Kul'cavchuk, V. M., Yu. B. Shishkin, and I. A. Berezin, Variation of temperature during the first stage of an electric explosion of wires, High Temp. (USSR) 4, No. 3, 399 (May - June).

Kutovoi, V. I., and Stetsenko, V. E., Checking the temperature of liquid metals by means of the radio-isotope method, Meas. Tech. (USSR) No. 8, 720 (Feb.).

Larson, R. E., and A. R. Hanson, Study of subminiature total temperature probes, Final Report, Litton Systems, Inc., Minneapolis, Minn., NASA-CR 76412; N66-31384 (June 7).

Lielmezs, J., and W. D. Groves, Negative temperatures, Nature 210, 723 (May 14).

Long, E. L. Jr., Thru metallographic observations, High temperature thermometry; paper presented at a seminar at AEC Headquarters, Washington, D.C., on February 24 - 26, 1965 (WASH-1067; TID4500) Washington: Division of Reactor Development and Technology, U.S. Atomic Energy Commissia 1966; N67-19624 (March).

Maglic, K. D., Thermocouples-a survey of properties, Teknika (Belgrade) 21, No. 9, 1857.

Manson, D. J., R. M. Delaney, and A. H. Weber, Flame-temperature measurement using $W / W-26 \% \operatorname{Re}$ thermocouples to correct optical pyrometer readings, Met. Soc. Conf. 30, 961 .

Mayer, D., Temperature measurement, Textilveredlung 1 , No. 11,568 .

McGee, R. S., and M. B. Say, A method for obtaining temperature profiles for solid propellant motor exhaust streams, Instr. Soc. Am. Ann. Conf. and Exhibit, 21st., New York, N. Y.; A67-11101 (Oct. $24-27$ ).

Melcher, J. C., Temperature measurement and control, Encyl. Ind. Chem. Anal. 3, 599.

Mette, H., and C. Loscoe, Measuring Seebeck coefficients on high resistivity materials, Rev. Sci. Instr. 37, No. 11, 1537 (Nov.).

Morris, J. F., Small plasma probes with guard rings arid thermocouples, NASA-TM-X-1294; N66-37684 , (Oct.).

Muller, E., The measurement of temperature, Instrum. Rev. 13, No. 180, 504 (Dec.).

Muller, E., The measurement of temperature, Part 5, Instrum. Rev. 13, No. 176, 324 (Aug.).

Muller, E., The measurement of temperature Part 6, Instrum. Rev. 13, 369 (Sept.). 
Pak, V., Bridge method for comparing precious- Watson, G. G., Techniques for measuring surface metal thermocouples, Meas. Tech. (USSR) No. 2, 149 (Feb.).

Palmer, E. P., and G. H. Turner, Response of thermocouple junctions to shock waves, Utah Research and Development Co., Salt Lake City, Utah, Contract: AF08(635)-5328; AD-484507 (April).

Parker, R., Method for determining the response of temperature sensors to a rapid temperature rise, Lawrence Radiation Lab., Univ. of Calif., Livermore Report No. UCRL-12484; NSA 20, No. 23, NSA No. 20-43635; A67-11100;N67-17425 (Dec. 15).

Samarin, A. M., Experimental techniques and methods of high temperature measurement, Izdatel'stvo, Nauka, (Moscow).

Schriener, H., and F. Wendler, Influence of the big size and mechanical surface treatment on the thermoelectric properties of thermocouples of $\mathrm{Sb}_{2} \mathrm{Te}_{3} / \mathrm{Bi}_{2} \mathrm{Te}_{3}$ and $\mathrm{Bi}_{2} \mathrm{Te}_{3} / \mathrm{Bi}_{2} \mathrm{Se}_{3}, \mathrm{Z}$. Metallkde 57, 708 (Sept.).

Schroder, K., M. J. Yessick, and N. P. Baum, Thermoelectric power and electrical resistance of chromium-iron alloys from $125^{\circ}$ to $625^{\circ} \mathrm{K}, \mathrm{J}$. App1. Phys. 37, No. 3, 1019 (Mar. 1).

Seifert, P., Current state of low-temperature measuring technology, Feingeratetechnik $\underline{15}$, No. 7,313 .

Smith, C. P., Survey of thermocouples, Eng. Mater. Design 9, No. 12, 1966 (Dec.).

Smith, w., et al, Temperature, pressure, density, and wind measurements in the upper stratosphere and mesosphere, National Aeronautics and Space Administration, Goddard Space Flight Center, Greenbėlt, Md., NASA-TR-R-245; N66-32285 (August.).

Van Voorish, M. F., et al, Thermocouple assembly, surface, North Am. Aviation Inc., Space and Information Systems Div., Downey, Calif., Final Specification Report No. SPEC-MC361-0011B; AD808158L (March).

Vrebalovich, T., Heat loss and recovery temperature of fine wires in transonic transition flow, Rarefied Gas Dynamics, Proceedings of the Fifth International Symposium, Oxford University, Oxford (Eng.) 2; AD67-28160 (July 4 - 8).

Wang, T. P., C. D. Starr, and N. Brown, Thermoelectric characteristics of binary alloys of nickel, Acta, Met. 14, No. 5, 649 (May).

Watson, G. G., Techniques for measuring surface temperature, Part 1, Instr. Pract. 20, No. 3, 217 (March).

Watson, G. G., Techniques for measuring surface temperature, Part 2, Instr. Pract. 20, No. 4, 335 (Apr.). temperature, Part 3, Instr. Pract. 20, No. 5, 447 (May).

Watson, G. G., Techniques for measuring surface temperature, Part V, Instr. Pract. (Aug.).

Weinberg, I., and C. W. Schultz, Thermoelectron power in niobium-zirconium alloys, J. Phys. Chem. Solids 27, No. 2, 474 (Feb.).

Wiser, N., Electrical resistivity of the simple metals, Phys. Rev. 143, No. 2, 393 (Mar. 11).

Transducers-pressure, temperature, velocity, force tongue, displacement, Electromechanical Design 10 (Jan.).

Industrial thermometry; towards higher and higher temperatures, Can. Chem. Process 50, 58 (Sept.).

High temperature probe works above thermocouple range, Hydrocarbon Process Petrol Refiner 39 , 157 (May).

High temperature thermometry, Seminar Washington D.C., Atomic Energy Commission WASH-1067 (Feb. $24-26)$.

\section{7}

Aleksakhin, I. A., et al, Problems of investigating thermoelectrode alloys, stable to oxidation up to $2000 \mathrm{C}$, Foreign Tech. Div., Wright-Patterson AFB, Ohio, Report No. FTD-HT-23-746-67; AD-662 573 (Aug.).

Arnold, J. E., and J.W. Baughn, Surface catalytic effects on heat flux measurements, ISA Tran. 6, No. 2, 127 (April).

Azizan, A. M., Elementary heat sensors under conditions of an arbitrarily time-varying temperature of the medium and heat-transfer coefficient, High. Temp. $\underline{5}$, No. 4, 586 (July - Aug.).

Bansal, T. D., Basis of calibrating temperature measuring instruments at NPL, Get-Together on Thermometry, Nat. Phys. Lab., New Delhi, Pap. $1.3(13-17$ Feb. $)$.

Barber, C. R., Engineering outline; temperature sensors, Engineering 203, 699 (April).

Berglund, C. N., and R. C. Beairsto, An automatic technique for accurate measurement of Seebeck coefficient, Rev. Sci. Instr. 38, 66 (Jan.).

Bonilla, C. F., High temperature thermal properties of gases and vapors, Columbia Univ., Dept. of Chem. Eng., New York, Progress Report, CU2660-32; Contract No. AT (30-1)-2660; NSA-23:984 (June - March).

Brown, C. R., The convective heat transfer bibliography, Final Report, AFML-TR-68-17; AD-668 769 (Feb.). 
Chandra, R., and N. C. Srivastava, Temperature sensing devices in automatic control systems, Get-Together on Thermometry, Nat. Phys. Lab., New Delhi, Pap. 4.9 (13 - 17 Feb.).

Clark, J. A., Transient temperature distribution within thermal sensing elements, Mass. Inst. of Tech., Dept. of Mechanical Eng., Cambridge Mass., Contract: DA-19-016 ENG-3204; Task: IV $025001 \mathrm{~A} 13001$; AD-818016 (May).

Copeland, K., Electricity, electronics, muscles and nerves, Electronics and Power 13, 464 (Dec.).

Daneman, H. L., and G. C. Mergner, Precise resistance thermometry-a review, Part 1, dc methods, Instrum. Techno1. 14, No. 5, 51 (May).

Daneman, H. L., and G. C. Mergner, Precise resistance thermometry-a review, Part 2, ac methods, Instrum. Techno1. 14, No. 6, 65 (June).

Danil'chenko, V. E., et a1, Apparatus for research from 4.2 to $300^{\circ} \mathrm{K}$, Prib. Tekh. Eks. (USSR) No. 1,208 ( $\operatorname{Jan}$. ).

Diamond, J. J., Bibliography of the high temperature chemistry and physics of materials in the condensed state, Nat. Bur. Stand. Special Publication 1967, 3, (July, Aug., Sept.) edited by J. J. Diamond, for International Union for Pure and Applied Chemistry Commission on High Temperatures and Refractories (IUPAC): Address to: J. J. Diamond, Nat. Bur. Standards; Washington, D.C. 20234

Diep, G. B., and G. Poissant, Installation and introduction into service of a temperature calibration room, National Center of Scientific Research, Meudon (France) Report. -67-5; N6816811 (July).

Field, J. E., Evaluation of the risetime of some intrinsically spotwelded thermocouples; Society for Experimental Stress Analysis, Ann. Meeting, Chicago, Ill; A68-15945 (Oct. 31 - Nov. 3).

Gardner, A. R., Measuring temperature without complex systems, Prod. Eng. 38, No. 20, 110 (Sept. 25).

Gates, D. W., Selected bibliography and abstracts of high temperature optical properties and their measurements, NASA, Marshall Space Flight Center, Huntsville, Ala., NASA-TM-X-53679; N6821895 (Dec. 8).

Holmes, A. B., et a1, Application of fluidics to sensing and controlling fluid phenomena, ASME, Design Engineering Conference and Show, New York, N. Y., Paper 67-DE-12 (May 15-18).

Ihrenberger, A., and F. Bensovsky, Metallography of oxide-metal materials, Prakt. Metallogr. 4 , No. 9,489 .

Inaitov, A. Ia., Microthermocouples and their installation and calibration by various devices, Akademiia Nauk Uzbekskoi, (SSR) Izv Ser Tekhich Nauk 11, No. 3, 64 .
Kaczovek, H. K., Measurement of air temperature at subsonic and supersonic speeds, Tech. Lotnicza Astronaut 22, 9 (March).

Kandyba, V. V., Increased accuracy of high tempera ture measurements in the USSR, Paper presented a the 4 th. Intern. Meas. Conf., Warsaw; N68-37610.

Kenda11, D. N., et a1, Semiconductor surface thermocouples for determining heat-transfer rates, Trans. IEEE AES-3, No. 4, 596 (July).

Kirenkov, I. I., Set of standards for temperature measurement, Meas. Tech. (USSR) 11, 1378 (Nov.).

Leewen, J. Van, Symposium: Handling viscous fluids 3. Measuring techniques, IV Temperature measurement in fluids with a high viscosity and a low thermal conductivity, Ingenieur's Grav., 79, 124 (Dec. 22).

Loeffler, R. F., Thermocouples, resistance tempera ture detectors, thermistors-which?, Instr. and Contro1 Systems 40, No. 5, 89 (May).

Marmer, E. M., et a1, High temperature materials, Air Force Systems Command, Wright-Patterson AFB, Ohio, Foreign Technology Div., FTD-MT-24-270-68; AD-696047; N70-14356 (May 6).

Maxwe11, G. M., et a1, Measurement of Thomson heat in metallic systems, Rev. Sci. Instr. 38, No. 8, 1084 (Aug.).

Miller, C. E., and T. M. Flynn, on the problems of measuring transient temperature in cryogenic fluids, Nat. Bur. Standards, Boulder, Colo., Inst. App1. Tech., NASA-CR-92741; N68-16729 (Apri1).

Mi11er, J. T., Temperature measurement, Part 1, Bio-Med. Eng. 2, No. 5, 200 (May).

Mogrini, U., Critical comparative observations of thermocouples and resistance thermometers having a small heat capacity, Termotecnica (Milan) 21, No. 1, 3 .

Murray, I., Heat bibliography 1966, Nat. Eng. Lab. Edinburgh, H.M.S.O.

Ohman, C. B., Preparation and installation of thermocouple wire, General Dynamics/Convair, San Diego, California, Final Report No. SPEC0-79044-016; AD-826831L (August).

Prakash, S., and B. H. Subbaraya, Langmiur probe for measurement of electron density and electron temperature in the ionosphere, Rev. Sci. Instr. 38, 1132 (Aug.).

Pungor, E., Flame photometry theory, Akademiai Kiads, Budapest, Hungary.

Raghaven, S., Sensors for upper air temperature measurement, Get-Together on Thermometry, Nat. Phys. Lab., New Delhi, Pap. 3.7 (13 - 17 Feb.). 
Ral1, D., and D. R. Hornbaker, A practical guide to temperature measurement, Proc. 22nd. Instr. Soc. Am. Ann. Conf. 22, No. 2, Paper No. P121-PHYMMID-67.

Ral1, D. L., and D. R. Hornbaker, Taking meaningful temperature measurements, Instrum. Technol. 14 , No. 10,63 (Oct.).

Regenczuk, T. J., Selecting temperature monitoring and control systems, Chem. Eng. 74, No. 25, 202 (Dec. 4).

Rein, C. R., and J. R. O'Laughlin, Correction for radiation absorbed by electrically heated wire temperature sensors in flame, AIAA, J. 5 , No. 10,1900 (Oct.).

Rubio, R., and H. N. Ballard, Time response and aerodynamic heating of atmospheric temperature sensing elements, Atmospheric Sciences Lab., Missile Range, White Sands, New Mexico, Proj: DA-1-V-650212-A-127; Task: 1-V-650212-A012703; AD-660321; N68-11326 (August).

Russman, H., Comparison of various methods for the experimental determination of temperature fields in laminar burner flames, Technsche Hochscule, Fakultat Fur Bergbau und Huttenwessen, Dr.-Ing. Dissertion, 67; A69-24635.

Sacher, I., Temperature measurements near $1600^{\circ}$ in Ceramic kilns, Sprechsaal Keram. Glas., Email, Silikate 100, No. 5, 185.

Samsonov, G. V., High-temperature nonmetallic thermocouples and sheaths, translation of Vysokotemperaturnye Nemetallicheskie Termopary, i Nakonachniki, Kiev, Izdatel'stvo, Naukovo, Dumka, N. Y, Consultants Bureau Div. of Plenum Publishing Corp.

Shah, V. V., Thin film temperature measuring devices, Get-Together on Thermometry, Nat. Phys. Lab., New Delhi, Pap. 4.13 (13 - 17 Feb.).

Shakhtin, D. M., Influence of impurity oxides on the electrical resistance of $\mathrm{MgO}$ at hightemperatures, Teplofiz. Vys. Temp. 5, No. 3, 510 (May - June).

Sherif, I. I., and A. W. Aziz, An experimental study of stability and accuracy of thermistors and thermocouples for precision temperature measurement in the range $0^{\circ} \mathrm{C}$ to $100^{\circ} \mathrm{C}$, GetTogether on Thermometry, Nat. Phys. Lab., New Delhi, Pap. 4.12 (13 - 17 Feb.).

Singleton, A. H., Temperature measurement U. S. Patent No. 3,308, 646 (C1. 73-1) Mar. 14, 1967, App1. (Oct. 14).

Sprawls, R. T., Ceramics for ultrahigh temperatures, Mach. Des. 39, No. 20, 93.

Stanford, R. H., The thermoelectric emf of mercury relative to platinum, Royal Aircraft Establishment, Farnborough (Eng.), Tech. Report No. RAE-TR-67185 (August).
Stark, W. A., Thermal pulsing of metals under high pressure, California Univ., Berkely Ph.D Thesis, N69-12646.

Talbot, J. E., Stumped by sensor problem?, Instrum. Technol. 14, 44 (Feb.).

Tikhonov, A. N., and V. B. Glasko, Methods for determination of temperatures of solid surfaces, Zn. Vychislit. Mat. Fiz. (USSR) 7, No. 4, 910 (July).

Tiukaev, V. I., and A. G. Shashkov, High-temperature materials of advanced technology and methods for studying their thermophysical properties at temperatures up to $3500^{\circ} \mathrm{C}$, Inzhen rno-Fizicheskii Zhurnal 12, 263 (Feb.).

Trenkle, F., and M. Reinhardt, Temperature sensing techniques, AGARD Flight Test Instrumentation, 335, CFSTI; N69-10548.

Valentin, P., Introduction to measurements of high temperatures, Paris, Institut Francais des Combustibles et de 1'Energie, 141, Discussion; A68-38745 (Apr.).

Voloshin, I. F., Thermoelectric measurements and monitoring, Minsk, Izdatel'stvo Nauka i Tekhnika.

Wagner, R. E., Dynamic study of temperature transducers by use of an optical method, J. Basic Eng., Trans. ASME, Series D, 89, No. 2, 287 (June).

Walling, J. C., Low-temperature techniques, J. Sci. Instr. 44, No. 9, 671.

Wang, T. P., Temperature sensors, Instr. Control Systems 40, No. 5, 103 (May).

Watts, J. L., Electrical and electronic sensing devices, Text. Mfr. 93, No. 1108, 148.

Weber, M. E., and W. Y. Chon, Distribution of ultrasonic cavitation intensities in a liquid system, Can. J. Chem. Eng. 45, 238 (Aug.).

Weinberg, I., Thermoelectric power in silver-gold and silver-germanium alloys, Phys. Rev. 157, No. 3, 564 .

Woernle, R., Apparatus for high temperature technology, Chemie-Ing. Tech. 39, No. 23, 1358 (December).

Temperature measuring devices, Automation 14, 79 (Feb.).

Bibliography, Cryogenics, Cryogenics 7, 309 (Oct. Dec.).

Temperature measurement systems, Final Report, June 7 - Aug. 7, 1967, NASA-CR-89988; N68-10001 (Aug. 14).

An analysis of a capacitor discharge technique for determining the rise time of temperature sensors, Sandia Corp., Albuquerque, New Mexico, Report No. SC-TM-67-561; AD-830662L (July). 
Pyroelectric ceramics for measuring low temperature, Nat. Bur. Stand. Tech. News Bulletin 51 No. 9,193 (Sept.).

Precise measurement of low temperature, Engineering 203, 1022 (Jan. 23).

High-temperature liquid-metal technology review, A Bimonthly Technical Progress Review, 5, No. 2, 41, Brookhaven, National Lab., Upton, New York; CFSTI, (Apri1).

Temperature measurements society, Conference and Exhibit, 5th, Proc., Temperature Measurements Society, Studio City, Calif. (March 14 - 15).

Heat can't hide from this thermocouple, Electronics 40, 202 (Dec. 11).

\section{8}

Alatyrtsev, G. A., Yu. N. Malecskii, and G. T. Eidinova, Solders for medium-temperature thermocouples, Preobrazovateli Soln-. Energ. Poluprov. (USSR) 60, No. 2 .

Astin, A. V., Standards of measurement, Sci. Am. 218, 50 (June).

Ayers, D. L., and M. W. Cobb, A comparison of thermocouples and thermistors for surface temperature measurement of low conductivity materials, Itek, Corp., Optical Systems Div., Palo Alto, California, Paper No. 68-511 (Oct. $28-31$ ).

Bayley, F. J., and A. B. Turner, Bibliography of heat-transfer instrumentation, Aeronautical Research Council (G. B.) ARC-R\&M-3512; N68-34071.

Beck, H., Temperature measurements in hot, fast moving gases with special consideration of their application to aircraft and spacecraft propulsion, Astronautik, 5, 36; A68-28032 (Mar.Apr.) .

Becker, H., Temperature measuring techniques, VDI Z 110, No. 17, 713; A68-32917 (June).

Bohl, D. R., and D. E. Sellers, A statistical evaluation of a gas pressure, volume, temperature measurement system, Maund Lab., Miamiasburg, Ohio, Contract AT(33-1)-GEN-53; MLM-1557; N69-15336 (Oct. 11) .

Brevik, I., and E. Suhonen, Relativistic coherence theory of blackbody radiation within a transparent medium, NORDITA, Copenhagen, Denmark, Phys. Norvegica 3 , No. 2, 135.

Claggett, T. J., and R. W. Warall, Temperature measurement and sensor selection, Instrumentation 21 , No. 1,6 .

Clark, D. D., Measurement of temperature in the upper atmosphere, European Space Research Lab., Noordwijk (Neth.), ESRO-SN-84(ESLAB) N68-37142 (Jan.).
Colorusso, V. G., and M. A. Semon, Measurement of calibration standards for thermometry, Anal. Chem. 40, No. 10, 1521 (Aug.).

Conrad, G., Linearization of thermocouple voltages Rev. Sci. Instr. 39, No. 11, 1682 (Nov.).

Considine, D. M., Process instrumentation; temperature indicating/recording/controlling systems, Chem. En. 75, 89 (Jan. 29).

Corruccini, R. J., Principles of thermometry (measurement of temperature) Cryogenic Eng. Lab., NBS, Boulder, Colorado, Treatise Anal. Chem $\underline{8}$, No. $1,4937$.

Cox, S. K., et al, Radiosonde temperature-baseline inaccuracy, J. Ap. Meteorology 7, 691 (Aug.).

Curtis, C. D., NUWC temperature calibration facility; recent improvements and interorganizational cross-calibration results, Naval Undersea Warfare Center, San Diego, California, Report No. NUWC-TP-27; AD-671193 (Feb.).

Curtis, D. J., Temperature transducer and measurement, Fundamentals of Aerospace Instrumentation: ISA, International Aerospace Instrumentation Symposium, 14th, Boston, Mass. Tutorial Proceedings, 1; A69-23225 (June 3 - 5).

Diamond, J. J., Bibliography on the high temperature chemistry and physics of materials, Nat. Bur. Stand. Special Publication 315; U.S. DEPT. of Commerce, Washington, D.C.; 20234 (Oct. - Nov. Dec.) .

Drenth, G., Estimation errors in reading mercuryin-glass thermometers, J. Sci. Instr. 2, No. 1 , 499 (April).

Duchan, C. E., Techniques for evaluating meteorological aircraft data, Texas Univ. Austin, $\mathrm{Ph} . \mathrm{D}$. Thesis; N69-25608.

Dutt, M., On the measurement of average temperatures in circular ducts, Rosemount Eng. Co., Minneapolis, Minn., Paper No. 68-518 (Oct. 28).

Eder, F. X., Methods for producing very low temperatures, Elektrotech. 2. (ETZ) A 89, No. 13, 304 (June).

Enge1, M., Methods and instruments for measuring temperature, Abt. Waerme Kraftwirt., Tech. Ueberwach.-Ver. Bayern e.V., Munich, Germany, Tech. Ueberwach 9 , No. 10, 328.

Findeis, A. F., Instrumental considerations for thermal methods, Proc. Am. Chem. Soc., Symp., 155 th.

Foley, J. J., G. E. Kropa, and S. E. Nydick, System of transducers and instrumentation for direct measurement and display of turbine inlet tempera. ture, Space Sciences Inc., Waltham, Mass. Report No. SSI-377; AD-834957 (Feb.).

Fuler, K. J., The state of high-temperature physics. Chem. Ing. Tech. 40, No. 1-2, 21 . 
Gaylord, A. M., and W. A. Compton, High temperature sensors for small gas turbines, Solar, San Diego, California, Report No. RDR-1479; AD-671 021; N68-32172 (Apr.).

Grey, J., Cooled probes for gas measurements at very high temperatures, Space/Aeronautics 50, 82; A69-10150 (Oct.).

Gruen, D. M. , D. S. Newman, and R. L. McBeth, Nul1 pressure optical cell for measurements of liquids at elevated temperatures and pressures, Argonne National Lab., Argonne, I11., Rev. Sci. Instr. 39 , No. 2 (Feb.).

Hartz, R. A., Selecting temperature transducers, Automation (Cleveland) 15, 68 (Aug.).

Hughes, R., and R. T. Simmons, Temperature measurements in the low temperature combusion of $\mathrm{N}$-pentane, Manchester Univ., Institute of Sci. $\notin$ Tech., Dept. of Chemistry, Manchester, Eng., Combust. Flame 12, 499 (Oct.).

Ivanov, V. Ye., High temperature oxidation protection of tungsten, Aztec. School of Language, Inc., Maynard, Mass., Translation of Russian Book Zashchita Volframaot Okisleniya pri Vysokikh Temperaturakh, NASA-TT-F-583; N69-35836.

Janowiecki, R. J., et al, Plasma-sprayed thermoelectric materials research, Monsanto Research Corp., Dayton, Ohio, Contract No. F33615-67-C1215; AD-832678 (Mar.).

Kandyba, V. V., Increased accuracy of high temperature measurements in the USSR, Techtron Corp., Glen Burnie, Md., NASA-TT-F-11931; N6837410 (Oct.).

Keyser, D. R., The dynamic response of thermometervell assemblies, Naval Ship Engineering Center, Phil. Pa., Report No. NAVSECPHILADIV-A669; AD-667730; N68-24270 (Mar. 16).

Kholopov, G. K., Calculation of emissivities of non-diffuse cavity-type sources, Optiko-

Mekhaniches Kaya Promyshlennost (USSR) 35, No. I, 1 (Jan.), Russian., Translation: Sov. J. Opt. Tech. 35 , No. 1,1 (Jan.).

Kirk, W. H., Thermocouple primer, Hagan/Computer Systems Div., Westinghouse Electric, Instr. Contro1 Systems, 41, No. 3 (March).

Koch, R. F., Cryogenic thermometry: methods and instrumentation, I11. Inst. of Tech. (Chicago) Thesis, Contract No. AT (11-1)-1629; C00-162910 (June).

Koshkin, I. A., V. A. Krat, and V. I. Ostroverkhov, Producing thermocouple sheaths from zirconium diboride, Ogneupory No. 1-2, 12 (Jan.).

Kuehn, L. A., and R. S. Weaver, System for recording temperature in the vicinity of liquid surfaces, J. Sci. Instr. $\underline{2}$, No. 1, 776 (July).

Leroux, J. P., Vector form for laws of metallic thermoelectric circuits: application to the measurement of temperatures, Rev. Gen. Therm. 7, No. 77, 527 (May).

Manton, S. M., and J. P. O'Donoghue, Temperatures at lubricated rolling/sliding contacts, Proc. Inst. Mech. Engrs. (London) 182, No. 41, Part 1, 813 .

McLaren, E. H., and E. G. Murdock, The freezing points of high-purity metals as precision temperature standards etc., Can. J. Phys. 46, No. 5, 369 (Mar. 1).

Morgan, E. S., Effect of stress on the thermal emf of Pt-Pt/13\% Rh thermocouples, J. AppI. Phys. 2, No. 1, 1421 (Nov.).

Morrison, R. G., et al, Instrument development branch annual report, 1968, Phillips Petroleum Co., Idaho Falls, Idaho, Atomic Energy Div., IDO-17299; NSA-23:41131 (Ju1y).

Ordyntsev, V. M., et a1, A pyramidal information system for acquiring data from sensors and for transferring them to a remote computer, Air Force Systems Command, Wright-Patterson AFB, Ohio, Foreign Technology Div., FTD-HT-23-910-68; AD-683962; N69-26170 (Oct.).

Owston, C. N., Application of thermistors to optical pyrometry and temperature control, $\mathrm{J}$. Sci. Instr. 2, No. 1, 1228 (Dec.).

Parkinson, G. J., and A. E. Dangor, and J. Chamberlain, Time resolved measurements of electron number density and electron temperature using 1 aser interferometry at $337-\mu \mathrm{m}$ wavelength, App1. Phys. Letters (G. B.) 13, 233; N69-14187 (Oct. 1).

Percy, J. W., Forty years of temperature measurement, Instr. Control Systems, 41, No. 5, 73.

Pinto, J. J., Industrial temperature measurement and control, Part 1 , Ind. Electronics 6,2 (Jan.).

Pinto, J. J., Industrial temperature measurement and control, Parts 2 and 3 , Ind. Electronics 6, 48 (Feb.); 6, 95 (Mar.).

Praddaude, H. C., An interpolation formula for gallium arsenide junction diode thermometer in the 1 to 100 degrees absolute range, Mass. Inst. of Tech., Cambridge National Magnet Lab., Contract No. F44620-67-C-0047; AD-690409 (Nov.).

Preobrazhenskii, V. P., and V. S. Chistyakov, Measuring the rapidly changing temperatures of a gas flow by means of quick-response thermal detectors, Meas. Tech. (USSR) No. 5, 631 (May).

Richter, M., Use of high purity materials in thermometry, NASA-Washington, D. C., NASA-TT-F11548; N68-18813 (Mar.).

Riester, E., Temperature rise in wind tunnels for power plants, Deut. Forschung. fur Lutt-und Raumfahrt, Brunswick, W. Germany; Rept. No. DLR-FB68-30; CFSTI; N68-34090 (Apr. 29). 
Rodina, A. A., M. A. Gurenich, and N. I. Doronichena, Changes in the stability of source palladium-rhodium alloys during their interaction with hydrogen, Zh. Fiz. Khim. 42, No. 7, 1822.

Roge1'berg, A. N., Thermoelectric properties of copper-titanium alloys, Tr., Gas. Nauch.-Issled Praekt. Inst. Splavov Obral. Isvet. Metal No. $25,27$.

Rogers, J. S, , et al, Comparison between gas thermometers, acoustic and platinum resistance on temperature scales between 2 and $20^{\circ} \mathrm{K}$, Metro logia 4 , No. 2, 74 (Apr.).

Rossler, F., Determination of magnesium flame temperature, Opt. Acta 15, No. 5, 487 (Sept.).

Semkina, N. V., et a1, Corundum tips for use in control thermocouples in the chemical industry, Tr. Vost. Inst. Ogneuporov No. 7, 172.

Shelley, R. D., and G. R. Miller, An ionic thermocurrent spectrometer, Utah University; Institute of Materials Research; Salt Lake City, Utah; Rept. No. IMR-68-052; AD-674878; N69-12131.

Snelleman, W., A flame as a primary standard of temperature, Physics Lab., Univ. Utrecht, Netherlands, Metrologia 4, No. 3, 117 (July).

Soviani, R., and I. Asavinei, Theoretical and practical aspects of the thermal inertia of temperature transducers, III, Experimental methods for determining the characteristic values of the thermal inertia of temperature transducers manufactured in Romania, Metrol. Ap1. 15, No. 9, 406 .

Spelman, J. W., Where rhenium is growing, Metal Progr. 93, 103; A68-19884 (Feb.).

Stottmann, P., Pressure and temperature measurements in the testing of jet engines, DFL-Mitt, 411; A69-20869, (Dec.).

Suckewer, S., et a1, Study of various methods of determining the temperature of a plasma in a MHD duct, Air Force Systems Command, WrightPatterson AFB, Ohio, Foreign Technology Div., FTD-MT-24-178-68; AD-683133; N69-27426 (Aug.) .

Swindel1s, J.F., Precision measurement and calibration: Selected NBS papers on temperature, Nat. Bur. of Stand. Special Publication 300, 2, 573 .

Syre, R., and K. J. Spencer, A bibliography of refractory metals, Advisory Group for Aerospace Research and Development, Paris, France; Rept. No. AGARD-BIB-5; Avail. Technivision Services, Maidenhead, England; N69-27128.

Thomas, R. A., Signal conditioning for commonly used transducers, ISA, International Aerospace Instrumentation Symposium, 14th, Boston, Mass.; A69-23228 (June 3-5).

Trodah1, H. J., Peltier measurements below 4K, Michigan State University, East Lansing, Michigan (Dec. 23) .
Vaillant, A., Method determines wet-bulb temperature with certainty, Chem. En. 75, 134 (Aug. 26)

Warsinawsky, I., Instrumentation, Selected Technol. for the E1ec. Power Ind. (NASA), 173, CFSTI; N69. 12581 .

White, G. K., Experimental techniques in 1owtemperature physics, London, U. K. Clarendon Press, Oxford University Press.

White, R. M., The determination of the elevated temperature Seebeck coefficients of common thermocouple materials referenced to platinum, Sandia Corp., Albuquerque, New Mexico, SC-RR68-538; CFSTI: NSA-23:3557 (Oct.).

Yamamoto, T., New applications of thermoelement for cooling semiconductor devices, IEEE Proc. 56,230 (Feb.).

Zoppa, J. M., and W. S. Bondowski, Technology of taming temperature, Mach. Des. 40, 159 (Dec. 5).

SNAP-21 Program, Phase II, Deep sea radioisotopefueled thermoelectric generator power supply system, Quarterly Report No. 9, July 1, 1968Sept. 30, 1968, 3M Co., St. Pau1, Minn., Contract No. AT (30-1)-3691.

Throw away thermometer is based on polyethylene, M. Plastics 45, 110 (June).

N.B.S. evaluates temperature sensors for air moving in ducts, Nat. Bur. Stand. Tech. News Bu11. 52, 25 (Feb.).

Temperature sensor requires no power to initiate an alarm, Prod. Eng. 39, 66 (Jan. 1).

N.B.S. advances new concept in low-temperature measurement, Nat. Bur. Stand. Tech. News Bull. 52, No. 4, 71 (Apr.).

Liquid metal fast breeder reactor (LMFBR) program plan, Argonne National Lab., I1linois, WASH1104 ; CFSTI (Aug̈.).

High temperature sensors for small gas turbines, Solar, San Diego, Calif., Report No. R68J-1433-8; AD-865878L (Sept.).

High temperature sensors for smal1 gas turbines, Solar, San Deigo, Calif., Report No. R68J-1433-9; AD-865879L (Oct.)

High temperature sensors for small gas turbines, Solar, San Diego, Calif., Report No. R68J-143310; AD-865882L (Nov.).

High temperature sensors for small gas turbines, Solar, San Diego, Calif., Report No. R68J-143311 ; AD-865880L (Dec.).

\section{9}

Ayers, D. L., and M. W. Cobb, A comparison of thermocouples and thermistors for surfacetemperature measurement of $1 \mathrm{ow}$ conductivity materials, ISA Trans. 8 , No. 2, 117. 
Barron, S., Thermocouple coments for nuclear rocket engine nozzles, Am. Ceram. Soc. Bull. 48, No. 8, 770 (Aug.).

Bates, H., F. Wald, and M. Weinstein, Lead telluride landing and segmentation study: Semiannual phase report, Feb. 1, - July 31, Tyco Labs. Inc., Waltham, Mass., Contract NAS5-9149; NASA-CR-73658:SAR-2; N69-16843 (july 31).

Bederov, V. M., et al, Instruments and method for determining temperature, pressure and density in the upper layers of the atmosphere; Joint Publication Research Service (JPRS), Washington, D.C.; Collection of Articles on Instrumentation for Studying Upper Atmosphere, 20 - 27; Oct. 22; CFSTI; N69-10253.

Bednarek, K., and B. Niedzialek, Design and calibration of measuring probes for studies of jet engine combustion chambers, Instytut Lotnictwa Praces, 37, No. 11; A69-32947.

Benedict, R. P., Fundamentals of temperature pressure and flow measurements, John Wiley $\&$ Sons, New York.

Bergmann, M. S., Reliability tests on Hickok turbine inlet temperature indicators, Mfr. P/N 580-440, Naval Air Developement Center, Johnsville, Pa., Aero Mech. Dept., Report No. NADCAM-6905; AD-850519 (Feb.).

Boyer, T. H., Derivation of the blackbody radiation spectrum without quantum assumptions, Univ. Maryland, College Park, Phys. Rev. 182, No. 5, 1374 (June) .

Caskey, G. R., D. J. Sellmyern, and L. G. Rubin, A technique for the rapid measurement of thermoelectric power, Rev. Sci. Instr. 40, No. 10, 1280 (Oct.).

Crawford, A. B., Sea-surface temperatures: some instruments, methods and comparisons, World Meteorological Organization, Geneva, Switzerland; Sea-Surface Temperature, 117,; Avail. W.M.O., Geneva, Switz., Fr. 16; N70-24782.

Davis, J. C., Radiation errors in air ducts under nonisothermal conditions using thermocouples, thermistors and a resistance thermometer; Nat. Bur. Stand. Special Publication, Building Science Series 26; N70-15597 (Nov.).

Dixon-Lewis, G., and G. L. Isles, Flame structure and flame reaction kinetics, III-Measurement of temperature profiles in flames at atmospheric pressure, Leeds Univ., Houldsworth School of Applied Science, Leeds, Eng., Royal Soc. (London) Proc. Series A 308, 517; A69-19489 (Jan. 28).

Downs, A., and C. Maclean, Improvements in or relating to welding thermocouples, British Patent No. $1,162,137$; NSA-23:46024 (Aug. 20).

Druzhinina, I. P., et a1, Thermoelectric properties of niobium-tantalum and niobium-zirconium alloys, Meas. Tech. (USSR) 8,1090 (Aug.).
Dugar, A. B., Compressor inlet temperature (C.I.T) sensors-a design evaluation, ASME, Annual Gas Turbine Conf. and Products Show, 14th, Cleveland Ohio, Paper 69-GT-18; A69-22499 (Mar. 9 - 13).

Erben, E., Temperature measurement above $1500^{\circ}$, Glas-Instrum.-Tech., Fachz. Lab. 13, No. 2, 77.

Fletcher, R., N. S. Ho, and F. D. Manchester, The residual resistivity and low-temperature thermopower of palladium-hydrogen alloys, Metal Phys. 1, S-59 (May).

Gaylord, A. M., High temperature sensors for small gas turbines, Solar, San Diego, Calif., Report No. RDR-1645; AD-866979 (Dec.).

Gaylord, A. M., W. A. Compton, and R. G. Furgurson, High temperature sensors for gas turbines, ASME, Annual Gas Turbine Conf. and Products Show, 14th, Cleveland, Ohio, Paper 69-GT-30; A69-22492 (Mar. 9 - 13).

Giedt, W. H., Determination of high gas-stream temperatures from short exposure probe responses ISA Trans. 8, No. 1, 43; A69-37005.

Hatcher, D. W., and N. G. Anderson, Absorbance thermometer, Oak Ridge Nat. Lab., Oak Ridge, Tenn., Ana1. Lett. 2, No. 7, 373.

Hormuth, G. A., Eight ways to measure temperature, Control Eng. 16, 98 (Mar.).

Jacobs, J. D., and A. H. Shade, Measurement of temperatures associated with bubbles in subcooled pool boiling, J. Heat Transfer, Trans. ASME Series C, 91, No. 123 (Feb.).

Jones, M., The determination of surface temperatures, European Space Research and Technology Center, Noordwijk (Netherlands) Paper presented in 1968, 6th, ESRO Summer School, Noordwijk, ESRO-TN-78; N69-37466 (Feb.).

Kaminski, R. K., Emergency thermocouple fittings, Instrum. Tech. 16, No. 11, 63 (Nov.).

Lee, R. D., Construction and operation of a simple high-precision copper-point blackbody and furnace, Nat. Bur. Stand., Inst. for Basic Stand. Washington, D. C., Nat. Bur. Stand. Tech. Note No. $483,15$.

Leventis, A. A., Computation of temperature sensor response characteristics using analysis of transient temperature information, Douglas United Nuclear, Inc., Richland, Wash., Paper of the 15th Ann. Am. Nucl. Soc. Meeting, Seattle, Wash. CONF-690609; N69-40144 (May).

Lynnworth, L. C., Sound ways to measure temperature, Instrum. Tech. 17, No. 4, 47 (Apr.).

McRonald, A. G., Thin-film gauge, Patent Application, Jet Propulsion Lab., Calif. Inst. of Tech., Pasedena, Contract NAS7-100; NASA-CaseNP0-10617; U.S. Patent-App1-SN-828920; N7012618 (May). 
Meddins, H. R., and J. E. Parrott, An apparatus for the high-temperature measurement of thermal diffusivity, electrical conductivity and Seebeck coefficient, Brit. J. Appl. Phys., Journal of Physics D, Series 2, 2, No. 5, 691 (May).

Meier, H. U., A combined temperature and pressure probe for compressible flow, AIAA J. 7 , No. 3 529, Technical Notes (Mar.).

Menzel, E., and J. Stahlknecht, Optical and thermoelectric thermometry of small spherical metal crystals, Inst-B. Physik TU Braunschweig, Abteilung fur Grezflachenphysik, W. Germany, Z. Angew. Phys. 26, No. 3, 216 (Feb.).

Merrian, J. D., W. L. Eisenman, and A. B. Naugle, Properties of photodectors, Naval Weapons Center, Corona, Calif., Report No. NWCCL-TP-884; AD-859860L (Aug.).

Muller, E., Temperature measurement and control Part 1 sensing devices, Control \& Instrumentation 1 , No. 2, 33 (June).

Nelson-Jones, L., Surface temperature thermometer, Wireless World 75, 180 (Apr.).

Parker, R. A., The [OIII] temperature for one "filament" in the Cygnus loop, Astrophys. J. 155, 359; A69-22430 (Jan.).

Petersen, J. F., TAC2D: A general purpose twodimensional heat transfer computer code (Users Manual) Gulf General Atomic, San Diego, Calif.; N70-21923 (Sept. 6).

Ragsdale, R. G., and A. F. Kascak, Simple equations for calibrating temperature distributions in radiating gray gases, NASA, Lewis Research Center, Cleveland, Ohio, NASA-TN-D-5226; N6925312 (May).

Rafique, M. M., and M. Saleem, Thermoelectricity (a bibliography) Atomic Energy Center, Lohare, Pakistan, Library Div., AECL-PAK-LIB-28; NSA23:44216; CFSTI: U.S. Sales only (Mar.).

Richards, F. A., and D. Walsh, Time-resolved temperature measurement of a laser-heated surface, Brit. J. Appl. Phys. Journal of Physics D, Series 2, 2, No. 5, 663 (May).

Sekhov, K. S., Noncontact temperature and heat flux measuring devices, Temperature Measurements Society, Conf. and Exhibit, 6th, Hawthorne, Calif., Proc.; A69-30154 (Apr. 21 - 22).

Shepard, R. L., Thermometry for fast breeder reactors, Oak Ridge National Lab., Tenn., Reactor Fuel-Process, Technol. 12, 205 (Spring).

Shoemaker, C. F., J. H. Meiser, and J. E. Davison, A theoretical medel for calculating the Debye temperature of solids, Dayton Univ., Research Inst., Dayton, Ohio, Rept. No. UDRI-TR-68-42; AFML-TR-68-340; Avail . CFSTT AD-685188; N6929579 (Jan.).
Simon, B. G., and J. Mandel, Laboratory measurements of air cavity temperature in a passenger car tfre, Eng. and Instrumentation 73C, 21 (Jan. June) .

Staffanson, F. L., Theoretical comparison of beads wires, and films as rocketsonde and sensors in the mesosphere, Utah Univ., Salt Lake City, NASA-CR-1286; N69-18126 (Feb.).

Sweet, G. E., W. W. Anderson Jr., and H. B. Miller Compensating radiometer, NASA, Langley Research Center, Langley Station, Va., Patent No. 3,433, 953; NASA-CASE-XLA-4556; N69-27484 (Mar. 18).

Thulin, A., Composite thermocouple-resistance sensors with linear output, J. Sci. Instr. $\underline{2}$, 1069 (Dec.).

Electronic thermometer checks circuits for signs of illness, Prod. Eng. 40, 161, (Apr. 21).

High temperature sensors for small gas turbines, Solar, San Diego, Calif., Report No. R69J-143312; AD-865881L (Jan.).

High temperature sensors for small gas turbines, Solar, San Diego, Calif., Report No. R69J-143313; $A D-865865 L$ (Feb.).

High temperature sensors for small gas turbines, Solar, San Diego, Calif., Report No. R69J-143314 ; AD-865864L (Mar.).

High temperature sensors for small gas turbines, Solar, San Diego, Calif., Report No. R69J-143315; AD-865884L (Apr.).

High temperature sensors for small gas turbines, Solar, San Diego, Calif., Report No. R69J-143316; $A D-865883 L$ (May).

Thermoresistors, Army Foreign Science and Technology Center, Washington, D. C., Report No. FSTCHT-23-775-68; AD-691976 (June).

Model 510A IN-SITU temperature recording system, National Oceanographic Instrumentation Center, Washington, D. C., Report No. IFS-70001; AD873443L (June).

Research analysis of advanced sensors for turbine inlet gas temperature, Solar, San Diego, Calif., Report No. RDR-1653-1; AD-868477L (Sept.). 


\section{Acknowledgment}

The authors acknowledge with thanks the assistance provided by their coworkers Susan Barger, Paula Felter, Linda Fout, and Marion Tabinski in preparing and typing this bibliography. They wish to thank the Library Staff, National Bureau of Standards, in particular, Elizabeth Tate, Chief, Library Division and Elizabeth Warner, Asst. Chief, Readers Services, etc. for their continued support in conducting the necessary library research and their assistance in reviewing and editing the material included in the Monograph. They are indebted to S. A. Tancredi, Chief of Information Service, National Technical Information Service and Thomas Lin, Technical Analysis and Retrieval Branch, Defense Documentation Center, for their valuable assistance and making available their facilities, for the literature search. 
FORM NBS-114A $(1.71)$

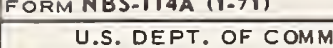 BIBLIOGRAPHIC DATA SHEET \\ 1. PÜBLICATION OR REPORT NO. NBS SP -373}

4. TITLE AND SUBTITLE

Bibliography of Temperature Measurement, January 1953 to December 1969.
2. Gov't Accession

No.

3. Recipient's Accession No.

5. Publication Date

November 1972

6. Performing Organization Code

7. AUTHOR(S)

Paul D. Freeze and Leslie P. Parker

8. Performing Organization

9. PERFORMING ORGANIZATION NAME AND ADDRESS

NATIONAL BUREAU OF STANDARDS

DEPARTMENT OF COMMERCE

WASHINGTON, D.C. 20234

12. Sponsoring Organization Name and Address

13. Type of Report \& Period Covered Interim

Jan. 1953 to Dec. 1969

Same as No. 9 .

14. Sponsoring Agency Code

15. SUP PLEMENTARY NOTES

16. ABSTRACT (A 200-word or less factual summary of most significant information. If document includes a significant bibliography or literature survey, mention it here.)

This bibliography consolidates into a single publication National Bureau of Standards Monograph 27 (January 1953 to June 1960) and its two supplements (September 13, 1963 and April 28, 1967, respectively) together with 1800 new references covering essentially the period from January 1966 to December 1969, but including some earlier citations previously omitted. The consolidated publication, which supersedes the earlier bibliographies, thus covers literature of temperature measurement published between January 1953 and December 1969.

In general, the arrangement of material in this new edition is the same as in Monograph 27, and the journal abbreviations are those employed in Chemical Abstracts. However, starting with 1963, and in the new material, scope of coverage in Part 1 was broadened to include theory, calibration, and temperature scales in addition to the previous categories of thermoelectric theory and calibration.

17. KEY WORDS (Alphabetical order, separated by semicolons)

Fluidic thermometers; pyromeiry; radiation pyrometry; temperature measurement; thermistors; thermocouple; thermometry.

18. AVAILABILITY STATEMENT

X] UNL IMITED.

FOR OFFICIAL DISTRIBUTION. DO NOT RELEASE TO NTIS.
19. SECURITY CLASS ('THIS REPORT)

UNCL ASSIFIED

20. SECURITY CLASS (THIS PAGE)
21. NO. OF PAGES 140

22. Price $\$ 2.00$ 


\section{PERIODICALS}

JOURNAL OF RESEARCH reports National Bureau of Standards research and development in physics, mathematics, and chemistry. Comprehensive scientific papers give complete details of the work, including laboratory data, experimental procedures, and theoretical and mathematical analyses. Illustrated with photographs, drawings, and charts. Includes listings of other NBS papers as issued.

\section{Published in two sections, available separately:}

\section{- Physics and Chemistry}

Papers of interest primarily to scientists working in these fields. This section covers a broad range of physical and chemical research, with major emphasis on standards of physical measurement, fundamental constants, and properties of matter. Issued six times a year. Annual subscription: Domestic, $\$ 9.50 ; \$ 2.25$ additional for foreign mailing.

\section{- Mathematical Sciences}

Studies and compilations designed mainly for the mathematician and theoretical physicist. Topics in mathematical statistics, theory of experiment design, numerical analysis, theoretical physics and chemistry, logical design and programming of computers and computer systems. Short numerical tables. Issued quarterly. Annual subscription: Domestic, \$5.00; $\$ 1.25$ additional for foreign mailing.

\section{TECHNICAL NEWS BULLETIN}

The best single source of information concerning the Bureau's measurement, research, developmental, cooperative, and publication activities, this monthly publication is designed for the industry-oriented individual whose daily work involves intimate contact with science and technology-for engineers, chemists, physicists, research managers, product-development managers, and company executives. Includes listing of all NBS papers as issued. Annual subscription: Domestic, $\$ 3.00 ; \$ 1.00$ additional for foreign mailing.

\section{Bibliographic Subscription Services}

The following current-awareness and literaturesurvey bibliographies are issued periodically by the Bureau: Cryogenic Data Center Current Awareness Service (weekly), Liquefied Natural Gas (quarterly), Superconducting Devices and Materials (quarterly), and Electromagnetic Metrology Current Awareness Service (monthly). Available only from NBS Boulder Laboratories. Ordering and cost information may be obtained from the Program Information Office, National Bureau of Standards, Boulder, Colorado 80302 .

\section{NOWPERIODICALS}

Applied Mathematics Series. Mathematical tables, manuals, and studies.

Building Science Series. Research results, test methods, and performance criteria of building materials, components, systems, and structures.

Handbooks. Recommended codes of engineering and industrial practice (including safety codes) developed in cooperation with interested industries, professional organizations, and regulatory bodies.

Special Publications. Proceedings of NBS conferences, bibliographies, annual reports, wall charts, pamphlets, etc.

Monographs. Major contributions to the technical literature on various subjects related to the Bureau's scientific and technical activities.

National Standard Reference Data Series. NSRDS provides quantitative data on the physical and chemical properties of materials, compiled from the world's literature and critically evaluated.

Product Standards. Provide requirements for sizes, types, quality, and methods for testing various industrial products. These standards are developed cooperatively with interested Government and industry groups and provide the basis for common understanding of product characteristics for both buyers and sellers. Their use is voluntary.

Technical Notes. This series consists of communications and reports (covering both other-agency and NBS-sponsored work) of limited or transitory interest.

Federal Information Processing Standards Publications. This series is the official publication within the Federal Government for information on standards adopted and promulgated under the Public Law 89-306, and Bureau of the Budget Circular A-86 entitled, Standardization of Data Elements and Codes in Data Systems.

Consumer Information Series. Practical information, based on NBS research and experience, covering areas of interest to the consumer. Easily understandable language and illustrations provide useful background knowledge for shopping in today's technological marketplace.

\section{CATALOGS OF NBS PUBLICATIONS}

NBS Special Publication 305, Publications of the NBS. 1966-1967. When ordering, include Catalog No. C13.10:305. Price $\$ 2.00 ; 50$ cents additional for foreign mailing.

NBS Special Publication 305, Supplement 1, Publications of the NBS, 1968-1969. When ordering, include Catalog No. C13.10:305/Suppl. 1. Price $\$ 4.50 ; \$ 1.25$ additional for foreign mailing.

NBS Special Publication 305, Supplement 2, Publications of the NBS, 1970. When ordering, include Catalog No. C13.10:305/Suppl. 2. Price $\$ 3.25$; 85 cents additional for foreign mailing.

Order NBS publications (except Bibliographic Subscription Services)

from: Superintendent of Documents, Government Printing Office, Washington, D.C. 20402. 
U.S. DEPARTMENT OF COMMERCE

National Bureau of Standards

Washington, D.C. 20234

OFFICIAL BUSINESS

Penalty for Private Use, $\$ 300$
POSTAGE AND FEES PAID U.S. DEPARTMENT OF CDMMERCE 215

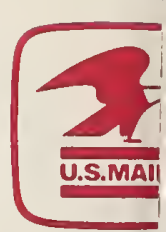

